\title{
Wage bargaining and spillovers : a two-country analysis: The Netherlands and Turkey
}

Citation for published version (APA):

Erdil, E. (2001). Wage bargaining and spillovers : a two-country analysis: The Netherlands and Turkey. [Doctoral Thesis, Maastricht University]. Universiteit Maastricht. https://doi.org/10.26481/dis.20010315ee

Document status and date:

Published: 01/01/2001

DOI:

10.26481/dis.20010315ee

Document Version:

Publisher's PDF, also known as Version of record

\section{Please check the document version of this publication:}

- A submitted manuscript is the version of the article upon submission and before peer-review. There can be important differences between the submitted version and the official published version of record.

People interested in the research are advised to contact the author for the final version of the publication, or visit the DOI to the publisher's website.

- The final author version and the galley proof are versions of the publication after peer review.

- The final published version features the final layout of the paper including the volume, issue and page numbers.

Link to publication

\footnotetext{
General rights rights.

- You may freely distribute the URL identifying the publication in the public portal. please follow below link for the End User Agreement:

www.umlib.nl/taverne-license

Take down policy

If you believe that this document breaches copyright please contact us at:

repository@maastrichtuniversity.nl

providing details and we will investigate your claim.
}

Copyright and moral rights for the publications made accessible in the public portal are retained by the authors and/or other copyright owners and it is a condition of accessing publications that users recognise and abide by the legal requirements associated with these

- Users may download and print one copy of any publication from the public portal for the purpose of private study or research.

- You may not further distribute the material or use it for any profit-making activity or commercial gain

If the publication is distributed under the terms of Article $25 \mathrm{fa}$ of the Dutch Copyright Act, indicated by the "Taverne" license above, 
Wage Bargaining and Spillovers 
ISBN

(C) Erkan Erdil 2001

Druk: Bizim Büro 


\section{Wage Bargaining and Spillovers}

\section{A Two-Country Analysis: The Netherlands and Turkey}

\section{PROEFSCHRIFT}

ter verkrijging van de graad van doctor aan de Universiteit Maastricht, op gezag van de Rector Magnificus, Prof. Dr. A.C. Nieuwenhuijzen Kruseman, volgens het besluit van het College van Decanen in het openbaar te verdedigen op donderdag 15 maart 2001 om 14.00 uur

door

Erkan Erdil 


\section{Promotor:}

Prof. dr. Chris de Neubourg

Beoordelingscommissie:

Prof. dr. J. Muysken (voorzitter)

Prof. dr. P.P. de Gijsel (Universiteit Utrecht)

Prof dr. J.J.M. Theeuwes (Universiteit Leiden) 


\section{CONTENTS}

List of Tables $\quad$ v

List of Figures viii

Preface $\quad$ ix

1. Introduction 1

PART I: PANORAMA OF THE DUTCH AND TURKISH LABOR MARKETS

2. Dutch Labor Market: A Real Consensus?

2.1. Postwar History of Dutch Labor Market (1945-1995) 7

2.2. Recent Policies in Dutch Labor Market 12

2.3. Stylized Facts on the Dutch Labor Market 16

2.3.1. Labor Force and Participation 16

2.3.2. Part-Time Employment 19

2.3.3. Unemployment 21

2.4. Trends in Employment and Wages in Dutch Manufacturing Industry 27

2.4.1. Employment 27

2.4.2. Wages 28

2.5. Institutions in Dutch Labor Market 30

2.5.1. Post-war History of the Dutch Trade Union Movement 30

2.5.2. Employers' Associations in the Netherlands 39

2.6. The Legal Framework of the Dutch Industrial Relations 41

2.7. Revisiting Dutch Labor Market $\quad 46$

Appendix 2A: The Chronology of the Dutch Trade Union Movement 49

Appendix 2B: International Standard Industry Classification (ISIC) 51

Appendix 2C: ILO and OECD Data on the Dutch Labor Market 53

3. Turkish Labor Market: The Victims of Instability 61

3.1. The History of Turkish Labor Market (1946-1995) 61

3.1.1. Articulation with the World Economy, 1946-53 61

3.1.2. Bottleneck and Adaptation, 1954-61 61 
3.1.4. Stabilization, Structural Adjustment, and Export-Orientation, 1980-Present 65

3.2. Main Characteristics of Turkish Labor Market

3.2.1. Labor Force and Participation

3.2.2. Part-Time Employment 72

3.2.3. Unemployment 73

3.3. Trends in Employment and Wages in Turkish Manufacturing Industry 78

3.3.1. Employment 78

3.3.2. Wages 80

3.4. Institutions in Turkish Labor Market 82

3.4.1. History of Turkish Trade Union Movement 82

3.4.2. Employers' Associations in Turkey 89

3.5. The Legal Framework of Turkish Industrial Relations 93

3.6. Revisiting Turkish Labor Market 97

Appendix 3: The Chronology of Turkish Trade Union Movement 101

4. Different Labor Markets?

4.1. A Comparative Perspective on the Dutch and Turkish Industrial Relations Systems 105

4.2. Comparing the Facts and Figures on Labor Markets 106

4.3. Routes to Wage Spillovers 108

4.4. Concluding Remarks 110

\section{PART II: THEORIES AND FANTASIES ON WAGE SPILLOVERS}

\section{Wage Spillover in Retrospect}

5.1. Introduction

5.2. A Typical Bargaining Model of Wage Inflation

5.3. Spillover Models of Wage Inflation

5.3.1. Wage Contour Hypothesis

5.3.2. Relative Deprivation Hypothesis 
5.3.6. Spillovers Through Wage Bargaining $\quad 130$

5.3.7. Wage Leadership Hypothesis 147

$\begin{array}{ll}\text { 5.4. Concluding Remarks } & 160\end{array}$

$\begin{array}{ll}\text { 6. Models of Wage Inflation } & 173\end{array}$

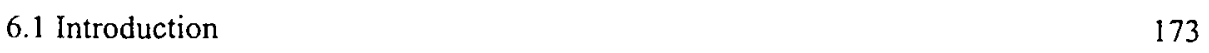

6.2. General Properties of the Bargaining Models 173

6.3. A Typical Model of Wage Inflation $\quad 177$

$\begin{array}{ll}\text { 6.4. The Wage Leadership Model } & 179\end{array}$

6.5. Concluding Remarks 184

Appendix 6: A Note on Modified Sims method 185

\section{PART III: WAGE DETERMINATION PROCESSES IN THE DUTCH AND} TURKISH MANUFACTURING INDUSTRIES

7. Wage Determination Process in Dutch Manufacturing Industry 191

$\begin{array}{ll}7.1 . \text { Introduction } & 191\end{array}$

7.2. A Bargaining Model of Wage Inflation $\quad 191$

7.3. The Wage Leadership Model 195

7.4. Sources of Wage Leadership 205

7.5. Concluding Remarks 209

Appendix 7A: The Complete Wage Leadership Model $\quad 212$

Appendix 7B: The Dutch Data $\quad 215$

Appendix 7C: SUR Estimates for the Netherlands with Inverse of Unemployment $\quad 219$

8. Wage Determination Process in Turkish Manufacturing Industry 225

8.1. Introduction $\quad 225$

8.2. A Bargaining Model of Wage Inflation $\quad 225$

8.3. The Wage Leadership Model 228

8.4. Sources of Wage Leadership 237

8.5. Concluding Remarks 237

Appendix 8: The Turkish Data 242 
9. An Overview on the Policy Implications of the Wage Leadership Hypothesis

9.1. Introduction

9.2. The Netherlands: All For One, One For All?

9.3. Turkey: From State Corporatism to Societal Corporatism?

9.4. Concluding Remarks

References

Samenvatting

285

Curriculum Vitae

293 


\section{LIST OF TABLES}

Table 2.1: Public Expenditure on ALMPs in EU Countries, 1994

Table 2.2: Total and Economically Active Population in the Netherlands, 1983-1995

Table 2.3: Participation Rates by Sex and Age Groups in the Netherlands, 1983-1995

Table 2.4: Reasons Given by Non-Participants by Sex and Age for not Seeking Work in the Netherlands in 1990 and 1996

Table 2.5: Unemployment Rates by Sex and Age Groups in the Netherlands, 1983-1995

Table 2.6: Employment Shares of Industries in the Netherlands, 1981-1994

Table 2.7: Wages in the Dutch Manufacturing Industry, 1970-1993

Table 2.8: Union Density Rates and Union Membership Developments in the Netherlands, 1946-1995

Table 2.9: Percentage Membership Share of Recognized Federations in the Netherlands, 1946-1995

Table 2.10: Inflow to and Outflow from Unions in the Netherlands, 1972-1993

Table 2.11: Working Days Lost in Manufacturing Industry due to Labor Disputes per 1000 Employees in European Union, 1986-1996

Table Al: ISI Classification

Table A2: Total and Economically Active Population in the Netherlands, 1970-1994

Table A3: Participation Rates by Sex and Age Groups in the Netherlands, 1975-1994

Table A4: Unemployment Rates by Sex and Age Groups in the Netherlands, 1975-1994

Table 3.1: Sectoral Distribution of Labor in Turkey, 1955-1960

Table 3.2 Total and Economically Active Population in Turkey, 1970-1995

Table 3.3: Participation Rates by Sex and Age Groups in Turkey 1988-1994

Table 3.4: Reasons Given by Non-Participants by Sex and Age for not Seeking Work in Turkey in 1994

Table 3.5: Unemployment Rates in Turkey, 1970-1994

Table 3.6: Unemployment Rates by Sex and Age Groups in Turkey, 1988-1994 75

Table 3.7: The Employment Shares of Industries in Turkey, 1970-1994 79

Table 3.8: Wages in Turkish Manufacturing Industry, 1970-1994

Table 3.9: Percentage Membership Share of Recognized Confederations in Turkey, 1984-1997

Table 3.10: Union Density Rates and Union Membership Developments in Turkey, 1984-1997

Table 3.11: Number of Employers' Associations in Turkey, 1963-1996

Table 3.12: Employers' Associations by Economic Activity in Turkey, 1987-1996 
Table 7.1: SUR Estimates of Bargaining Model for the Netherlands with Vacancy-

Unemployment Ratio, 1971-1993

Table 7.2a: Wald Statistics for the Netherlands-Following Sectors

Table 7.2b: Wald Statistics for the Netherlands-Leading Sectors

Table 7.2: Number of Wage Leading and Wage Following Sectors Per Sector in Dutch

Manufacturing Industry, $1971-1993$

Table 7.3: Granger Causality Results for the Netherlands

Table 7.4: SUR Estimates of Wage Leadership Model for the Netherlands with VacancyUnemployment Ratio, 1971-1993

Table 7.5: Tests of Wage Leadership Hypothesis for the Netherlands with VacancyUnemployment Ratio, 1971-1993

Table 7.6: Effects of Unionization on Estimates of Wage Leadership Model for the

Netherlands with Vacancy-Unemployment Ratio, 1971-1993

Table7.7: Effects of Concentration on Estimates of Wage Leadership Model for the Netherlands with Vacancy-Unemployment Ratio, 1971-1993 208

Table 7.8: Combined Effects of Unionization and Concentration in the Netherlands

Table A : SUR Estimates of Bargaining Model for the Netherlands with Inverse of Unemployment Ratio, 1971-1993

Table A2: SUR Estimates of Wage Leadership Model for the Netherlands with Inverse of Unemployment Ratio, 1971-1993

Table A3: Tests of Wage Leadership Hypothesis for the Netherlands with Inverse of Unemployment Ratio, 1971-1993

Table A4: Effects of Unionization on Estimates of Wage Leadership Model for the Netherlands with Inverse of Unemployment Ratio, 1971-1993

Table A5: Effects of Concentration on Estimates of Wage Leadership Model for the Netherlands with Inverse of Unemployment Ratio, 1971-1993

Table 8.1: SUR Estimates of Bargaining Model for Turkey with Inverse of Unemployment Ratio, 1971-1994

Table 8.2a: Wald Statistics for Turkey-Following Sectors

Table 8.2b: Wald Statistics for Turkey-Leading Sectors

Table 8.2: Number of Wage Leading and Wage Following Sectors Per Sector in Turkish Manufacturing Industry, 1971-1994

Table 8.3: Granger Causality Results for Turkey

Table 8.4: SUR Estimates of Wage Leadership Model for Turkey with Inverse of 
Table 8.5: Tests of Wage Leadership Hypothesis for Turkey with Inverse of Unemployment Ratio, 1971-1994

Table 8.6: Effects of Unionization on Estimates of Wage Leadership Model for Turkey with Inverse of Unemployment Ratio, 1971-1994

Table 8.7: Effects of Concentration on Estimates of Wage Leadership Model for Turkey with Inverse of Unemployment Ratio, 1971-1994

Table 8.8: Combined Effects of Unionization and Concentration in Turkey

Tablc 9.1: Rank Orderings of Countries According to Their Degree of Centralization

Table 9.2: Rank Orderings of Countries According to Their Degree of Corporatism 


\section{LIST OF FIGURES}

Figure 2.1: Participation Rates by Sex in the Netherlands, 1983-1995 17

Figure 2.2a: Share of Part-Time Employment by Sex in the Netherlands, 1985-1996 20

Figure 2.2b: Males and Females Employed Part-Time as Percentage of All Employed Males and Females in the Netherlands, 1987-1996

Figure 2.2c: Females Employed as Percentage of All Part-Time Employed People in the Netherlands, 1987-1996

Figure 2.3: Unemployment Rates by Sex in the Netherlands, 1983-1996 22

Figure 2.4: Duration Structure of Unemployment in the Netherlands, 1990-1996 25

Figure 2.5: Unemployed and Vacancies in the Netherlands, 1960-1995 26

Figure 2.6: Employment in the Dutch Manufacturing Industry, 1970-1993 27

Figure 2.7: Real Hourly Wages in the Dutch Manufacturing Industry, 1970-1993 30

Figure A1: Participation Rates by Sex in the Netherlands, 1975-1994 57

Figure A2: Share of Part-Time Employment in the Netherlands, 1975-1991 57

Figure A3: Unemployment Rates by Sex in the Netherlands, 1975-1994 59

Figure A4: Duration Structure of Unemployment in the Netherlands, 1983-1989 59

Figure 3.1: Participation Rates by Sex in Turkey, 1988-1994 71

Figure 3.2: Share of Part-Time Employment in. Turkey, 1988-1995 72

Figure 3.3: Unemployment Rates by Sex in Turkey, 1988-1994 74

Figure 3.4: Duration Structure of Uncmployment in Turkey, 1988-1995 76

Figure 3.5: Unemployed and Vacancies in Turkey, 1981-1994 77

Figure 3.6: Employment in Turkish Manufacturing Industry in Turkey, 1970-1994 78

Figure 3.7: Real Hourly Wages in Turkish Manufacturing Industry in Turkey, 1970-1994 80

Figure 5.1: Hick's Bargaining Model 133

$\begin{array}{ll}\text { Figure 5.2: Contract Zones for Wages } & 137\end{array}$ 


\section{PREFACE}

In the preparation of this thesis, I am indebted to my supervisor, Prof.dr. Chris de Neubourg, because of his invaluable help and advice at each stage of the study. Without his support it would have been impossible to conduct and complete the study. Moreover, the interest and helpful comments on the early version of this study given by Prof.dr. Joan Muysken, Prof.dr. Zehra Kasnakoğlu, Prof.dr. Erol Taymaz, Prof. dr. P.P. de Gijsel, Prof dr. J.J.M. Theeuwes, dr. Eric de Regt, and dr. Tom van Veen cannot be denied and the encouragement of former Chairman of the Department of Economics and, now, the Dean of the Faculty of Economics and Administrative Sciences at Middle East Technical University, Prof.dr. Oktar Türel is greatly appreciated. Furthermore, I am also thankful to all members of the Department of Economics both at Maastricht University and Middle East Technical University, Marcel Lever from EIM and officers at Central Bureau of Statistics in obtaining the Dutch data, Ferman Yerli from the Ministry of Labor and Social Security, Sermin Altın and Bülent Tungul from the State Institute of Statistictics in obtaining Turkish data, Jeffrey Meens for his helps in some Dutch texts and obtaining data, the lovely secretaries of the department Lilian Raetsen, Tilly Loth, Anke Wijnen, Celine Rondagh, and Mieke Drossaert, Ika Ploumen from Office for International Cooperation, and Yıldırım Kırgöz and Barı̧ Cakmur in reviewing some parts of the text. In a more informal way, I am really thankful to my parents, my lovely wife Aysun, my little daughter İpek, my friends Ramazan Ekinci, Ümit Efendioğlu, Cahide Cavuşoğlu, Önder and Funda Nomaler, Neslihan and İ.Hakan Yetkiner, Firuz Orhon, Ferruh Kılıçcıoğlu, and all my other friends for their encouragement without which it would not have been possible to complete this study. The heaviest burden, however, was borne by Aysun, my wife. She deserves special thanks for always being there.

Erkan Erdil, January 2001 


\section{INTRODUCTION}

The main motivation of this study is to clarify the institutional mechanisms in wage determination processes with two specific examples; the Netherlands and Turkey. In most of the studies on labor markets, the institutional mechanisms are either totally ignored or frankly treated without any legitimate theoretical background. As a starting point, we are going to deal with the classical dichotomy between market and institutional forces in the determination of wages. However, it is not a real dichotomy indeed. The latter approach to the labor market generally uses the main premises of the former and introduces some extensions such as rigidities or market imperfections. The orthodox model assumes perfect competition and unique equilibria, on the other hand, the institutionalists point to pervasive market power and to indeterminancy even under competition. For instance, Common (1924) argued that in the labor market, the employer possessed superior information, resources, and bargaining power as compared to individual workers; Webbs (1920) claimed that the labor contract was indeterminate regardless of the degree of competition, leaving its terms to be specified by custom, bargaining, or law (Jacoby, 1990:164-65). In the orthodox view, an individual's wants are taken as given and exogenous to the realm of economic need satisfaction dominated by efficiency forces. The institutionalists hold instead that market exchange is mediated by social institutions that determine and are at the same time determined by individual wants and behaviors. The orthodox view takes the utilitarianist assumption that homo economicus is guided by rational self-interest, whereas the institutionalists derive from pragmatism and other resources their belief that economic theory has to be based on behavioral and psychological (or self-interest) factors rather than on assumptions about economic behavior per se. Finally, in the orthodox view, economic theory is synchronic: an abstraction from reality that isolated its transhistorical and universal aspects. On the other hand, the institutionalists emphasize that the abstractions of economic theory are neither timeless nor placeless but instead are an ideal type.

The institutional labor economics trace the anomalies they observe to the same flaws in the orthodox model that the institutionalist had earlier identified like nonclearing labor markets, wage rigidity, persistent wage differentials, labor immobility, internal labor markets, and bargaining power. The institutional labor economics build a wide range of eclectic, middle-level theories that bridge the 
abstractions of pure theory and the institutional realities of labor markets rather than espouse the creation of a new body of theory based on realistic assumptions. Although critics fault the institutional labor economics for failing to develop a substitute for neoclassical theory, the middle-level approach is a reasonable way to proceed given the growing realization that neoclassicism's theoretical core is surrounded by impenetrable bands of conditional clauses (Latsis,1976 and Kerr,1988). Nevertheless, during the 1970s and 1980s a new trend emerged in labor economics. Various anomalies from the institutional labor economics tradition became the subject of theoretical concern; internal labor markets, wage differentials, wage rigidity, and unionism. Economists began to study employment institutions that gave rise to the new efficiency-oriented institutional labor economics. This trend is a heterogeneous bulk of research ranging from work that is avowedly institutional to more neoclassical and even Marxian approaches.

According to the generally accepted orthodox view, the market mechanism determines the structure of relative wages and the dynamics of general the wage level. The theoretical basis of this approach is implicitly Neo-Walrasian; the labor market is assumed to be atomistic, with all labor market participants acting as wage takers and accepting as given the real and relative wages called out by the market auctioneer. Institutionalists have generally been led to argue that the neoclassical approach to wage determination is clearly false since labor markets do not typically resemble auction markets and must rather be seen as institutionalized markets in which wages are administered either unilaterally by firms or bilaterally by firms and unions in a collective bargaining process. Furthermore, institutionalists deny that the dynamics of the modern institutionalized labor markets can be explained in terms of this orthodox vision and support the idea that the process of wage adjustment can be best explained by social and political forces in general and institutional forces in particular.'

In this study, two models of wage inflation will be offered: a typical bargaining model and the wage leadership model as a representative version of the spillover models of institutional tradition. In the literature, the spillover forces have been described under numerous names as wage leadership, relative deprivation, key bargains, pattern wage bargains, and others. All of these forces concentrate on the role

' For the detailed examination of institutional analysis see for example Addison (1975), Addison and Burton (1977, 1978, 1979, 1984), Addison and Siebert (1979), and Rima (1981). 
of wage relativities in the wage determination process. The wage leadership hypothesis postulates that the level of money wages in any one sector of economy is determined by a comparison to a given set of wages in the wage leading sector. The theme behind the wage leadership hypothesis is that a certain key group of industries act as pattern setters in the wage determination and there is a causal ordering in the wage setting patterns in that wage increases in the key sectors lead to wage increases in the other sectors of the economy. The role of wage leader could be played by different sectors in course of time or by the same sector continuously over time depending upon the subjective conditions of a country under consideration.

In the first part of the study, the structure of labor markets for both the Netherlands and Turkey will be evaluated in a historical context and features of labor market, labor force participation, unemployment, employment, wages, institutions, and legal framework of industrial relations will be analyzed. Finally, the differences and similarities between these countries will be discussed.

The second part presents a detailed survey of both previous theoretical and empirical studies on wage spillover processes in the labor markets. This survey will help us in modeling our approach and give lessons especially on empirical issues or difficulties in labor markets. The first major and crucial finding of the survey is the definition of spillovers in general and wage leading-following behavior in particular. Moreover, it will give some important clues for the specification of our model. In the following chapter, first, the general properties of the bargaining models will be analyzed. Second, a typical bargaining model of wage inflation will be presented. Finally, the wage leadership formulation as a representative version of spillover models of wage inflation is derived. In order to find the factors affecting the wage imitation behavior, sectoral unionization rate and sectoral concentration ratio will be offered as possible sources of wage imitation. Tests for the effects of these variables will complete the analysis. Therefore, this chapter provides the tools of analysis for the next chapter concerning the empirical application.

Then, in the final part, empirical application part of the study, both the bargaining and the wage leadership models will be estimated by Seemingly Unrelated Regression (SUR) method of estimation and the results of these models will be compared. However, the aim of the study is not to compare these two countries. The following chapter will discuss the policy relevance of the wage leadership in the light of the empirical findings. It may be the case that an economy with strong wage 
leading behavior has more likely to control the wage growth if it has an access to control the wages in the leading sectors. Therefore, macro wage policy will reduce a sector-specific policy. These points and the recent situation in the Netherlands and Turkey will be discussed. Moreover, the situation in these countries, according to the findings of previous two chapters, will be compared and contrasted. Finally, the analysis will end with the general discussion of results and concluding remarks. 


\section{PART I: PANORAMA OF THE DUTCH AND TURKISH LABOR MARKETS}

Part I consists of 2-4. In chapters 2 and 3, the post World War II structure of the labor markets in the Netherlands and Turkey are discussed in a historical perspective. The Dutch and Turkish labor markets are treated separately. This analysis gives an insight for the development of labor market institutions in both countries. Furthermore, it also supplies important clues both for the interpretation of econometric findings and in prescribing labor market policy implications of the results. In these two chapters, first the main characteristics of the labor markets are presented. Historical developments in industrial relations systems are examined with specific reference to trade unions and employers' associations in the second section. Finally, the legal framework in the wage determination process is discussed. Chapter 4 compares and contrasts the labor markets of two countries and specifies the routes to wage spillovers. 
2. DUTCH LABOR MARKET: A REAL CONSENSUS?

\subsection{Postwar History of Dutch Labor Market (1945-1995)}

In most of the Western European economies, as put forward by Crouch (1977:19), it is possible to observe five main peculiarities:

- a government policy that is supported by all political parties and society aiming to reach full employment,

- government engagement towards welfare state,

- the cooperation of trade unions in the elaboration and practice of national, social, and economic policies,

- a role for central union leadership in a responsible wage policy directed to incorporate price stability with full employment,

- acceptance by all major political parties of a policy of trying to keep industrial relations out of political controversy.

All these characteristics can as well be observed for the Dutch case. In the Netherlands such a settlement was initiated in illegal meetings during the war in 1943 when leaders of central organization of employers and trade unions agreed a new approach to industrial relations. From this time on they would negotiate through a joint association called as Stichting van de Arbeid (Foundation of Labor-SvdA) (Visser, 1992:325). After the war, this organization was installed by the government as its top advisory body in socio-economic policy making affairs. In fact, the industrial relations system can be truly called "tripartite" since all bodies such as SvdA included representatives from government, trade unions, and employers' associations.

Windmuller (1969:434-38) described three main characteristics of postwar Dutch labor relations system:

- There was an unusual degree of government intervention as demonstrated in the centralized wage policy under a government appointed Board of Mediators.

- The policy depended on government consultation with organized interest groups before decision-making process. This system was highly institutionalized in an overabundance of rules and boards. Besides SvdA, a tripartite SociaalEconomische Raad (Social Economic Council-SER) was established in 1950 with 
equal representation of employers' associations, trade union confederations, and government-appointed but independent experts. The SER was granted broad advisory and executive power in socio-economic policy making.

- Centralization was the most important characteristic of the Dutch system, especially in the first decade after the war. Consultation was limited to the leaders of central organizations, collective bargaining had the form of national wage rounds and was carried by a handful of officials, their advisors, the SER, and the minister, and employers almost had no discretion over the pricing of goods and services and wages (Visser, 1992:325).

Driehuis (1975:656-58) summarized the targets of wage policy with respect to five periods after the war:

- 1945-54. Controlled nation-wide wage increases based on increased costs of living: In this period, wage policy principally directed to a constant real wage per worker and the sole function of wage increases was to compensate the rising cost of living. The target of wage policy was to correct the balance of payments disequilibrium and to accelerate the growth rate by restricting the share of consumption in national income. The 1945 "Extraordinary Decree on Labor Relations" assigned to the government extensive powers to approve, reject, or modify wage contracts (Wolff,1983:204). It also formally recognized the Foundation of Labor which was composed of the country's three main trade union organizations and three employer's associations as an advisory body. The administrative role is played by the Board of Mediators. The legislation empowered this board to extend the terms of a collective bargaining agreement to cover the entire industry, even where only part of it was unionized (Griffiths, 1980). The rules were really strict in that firms were not allowed paying wages either above or below those bargained in the contract. In the period of 1945-1954, this system functioned well. Nominal wages were increased by uniform wage rounds planned to keep real wages stable since the main targets were to rebuild the damaged infrastructure of the country after the war, to improve negative balance of payments, and to make growth possible. Prices were kept under strict control, only cost increases resulting from the rising import prices were allowed to be reflected. 
- 1955-59, Controlled nation-wide wage increases based on the share of wages in national income: The second phase began with the SER's recommendation to increase average nominal wage levels in accordance with the net national income per economically active person. In this period, wage increases were also based on labor productivity increases because of the improved economic circumstances, thus deviating from the system of uniform wage rounds. An increase in the wages was possible to the extent that a comparison of per capita wages in the firms with the national income per capita of the active working population. Therefore, the share of wages in national income was applied as a criterion yet the link with the cost of living was partly preserved.

- 1960-62, Controlled wage increases based on the differences in productivity increases: The third phase began with the adoption of SER's majority recommendation to allow greater flexibility. The realization of this idea led to a complicated set of rules because of the desire to keep national average of increases in wages and productivity aligned as much as possible (Wolff,1983:205). This wage policy was based on the trend of productivity growth per sector of industry. Wages could rise faster than the general average when the productivity of a sector increased faster, yet the productivity increase had also to be revealed in product prices. Industries where productivity rose more than the national average could use half the difference for above average wage increases, the remainder was to go to price reductions. Where productivity lagged behind, on the other hand, only half of the difference could be passed on in prices and the other half had to be covered by wage increases below the national average (Wolff,1983). A substantial prerequisite for the application of this type of wage policy is a satisfactory price control to secure that productivity gains are certainly reflected in prices (Turner and Jackson,1969).

- 1963-68, Controlled wage increases based on a yearly target for national average wage increases: ${ }^{2}$ By the middle of 1963 , labor shortages led the ship-repair industry open a revolt and the shipyards' decision to pay wages above those agreed upon signaled the end of the third phase (Wolff,1983:205-206). A significant unrest together with strikes was observed and the peace was restored 
with an overall wage increase of $10 \%$ during the 1963 wage negotiations. This wage increase showed a need for a new policy. In the fourth phase, the wage policy was a reaction to difficulties in the system of differentiated wage determination in practice. Instead of productivity trends, the anticipated macroeconomic possibilities in terms of the attainment of economic policy goals were used. The position of govermment was secondary though it might potentially have intervened in the wage determination process. Wolff (1983:206) treated the new policy as unsuccessful in the sense that the three parties of the SER could not agree on guidelines and the Foundation of Labor could not oppose contracts signed between their member organizations.

- 1969-75, Free wage negotiations: A new system without central authority was established after 1968. However, this sometimes took a form of social contract. Wage differentiation in sectors of the economy was likely to follow. In spite of the fact that the Extraordinary Decree of 1945 was technically still in effect, its scope was largely eroded. The Minister of Social Affairs proposed a new bill on wage formation in which it recognized the principle free wage negotiations, yet the Minister was authorized to implement general wage measures if this was necessary as a result of the economic situation and intervene to the specific contracts (Wolff,1983:219-22). An article of law that empowered government to intervene wage negotiations in the event that wage increases were not compatible with the goals of economic policy existed, but it was not used and deleted from the law in 1976. Another miles stone in wage developments in the second half of the 1970 was the dispute experienced in the wage negotiations in Rotterdam Harbor where wages were increased by a lump sum of 400 guilders (Wolff,1983). The effect of this increase can be observed in other negotiations and wage adjustments rapidly spread throughout the economy even including civil servants. Furthermore, after this date, many contracts contained provisions for the anticipated future price increases.

In 1973, a central agreement was negotiated that made an effort towards to meet the unions' demand for greater equality of incomes and an equalizing mechanism was built in through minimum and maximum per cent price increase

${ }^{2}$ In the Netherlands, it may be possible to say that de facto the guided wage policy ended in 1964. 
(Wolff,1983). The effects of first oil crisis were felt in 1974. The govermment imposed an increase in all wages by three steps of 15 guilders each spread out over the year, in total equivalent to $3 \%$ of overall wage bill, and price controls were strictly applied (Wolff,1983). The recovery of the world economy starting in 1976 was observed in the Netherlands by a mild cyclical upswing that lasted until second oil crisis in 1979. The effects of the second oil crisis were more serious than the first one and resulted in the 1980 wage negotiations controlled by the government. Apart from specific allowances, no initial improvements were allowed and for the first time wages rose less than prices, and profit margins did not improve because of rising import prices, foreign competition, and price controls (Wolff,1983). Since the Dutch economy is highly interrelated with the world economy through international trade, the impacts of oil crises were significant. However, there was a counterbalancing force in effect. The discovery of a huge deposit of natural gas in the late 1950s led energy-intensive industries to develop quickly and to maintain a positive balance of payments on current accounts and a strong currency during the years of world oil crises.

During the $1970 \mathrm{~s}$ an attempt has been undertaken to strengthen the coordination of the labor market policy and social partners' role in the employment policy by the formation of a Labor Market Council which was founded in 1969 and followed by the establishment of regional councils for each province in 1971 (Miltenburg,1991:10). However, this structure did not work sufficiently enough to ensure the harmonization of government policy with the role and activities of the organized industry. Cooperation was impeded by the lack of coalition from both employers, employees, and parts of the government itself (Miltenburg,1991).

In the early 1980s, the Netherlands experienced its worst economic setback since the Second World War. Salaries and benefits were frozen in 1982 and incomes lowered by $3 \%$ in 1983 causing a major conflict with public service unions (Visser,1992:343). Salaries remained frozen in the succeeding years and it was partially compensated by a two-hour reduction on average per week. Moreover, the same measures applied to the minimum wage and social benefits tied to salaries. In 1987 , major changes in the system of social security were introduced and a new Unemployment Act was promulgated in which a lower benefit level and a shorter 
period of entitlement were included (Visser, 1992). ${ }^{3}$ In the private sector, the period between 1982 and 1986 was the period of wage moderation. Following the recommendations of the central agreement in 1982, COLA clauses were frozen and abolished and labor's share in the national income fell to $80 \%$ in 1986 which was $91 \%$ at the end of 1970 s (Visser,1992). Over the period 1977-87, unit labor costs rose by an annual average of $2.5 \%$ that is the lowest rate of increase in the European Community (EC) (Visser,1990:223-24). This trend is mainly related with the lower wage costs observed between 1982 and 1987. In the period, 1987-1990 the wage cost and unit labor cost increases in the Netherlands still remained far below the EC average (OECD, 1991). Predominant bargaining level in the 1980s has shifted from the central one to sectoral one (OECD,1994a:24-25).

\subsection{Recent Policies in the Dutch Labor Market}

The preparation of a draft of the new Employment Act started in May 1980. The main aim of this legislative project was the creation of an adequate set of means to achieve the optimal allocation of jobs. This goal combines the efficient and fair job allocation and a basic principle of the new act is that the Employment Service is one of the organizations operating and working in the labor market (The Employment Act, 1981). As a consequence of this principle the public employment service has lost its monopoly position. The general opinion is now that social relations have evolved to the point where the protection under the old act overshoots its target, while charges for job-finding can also be kept under control by other means (The Employment Act,1981). With the promulgation of the new Employment Act the door was open for an active role by private companies in matching of demand and supply on the market. Therefore, it can be stated that the central target of the new act was to promote an efficient and fair matching of supply and demand in the labor market. This implied that the main task of the Employment Service was mediating between employers and job seekers (Employment Service,1991). The activities of the Employment Service

\footnotetext{
${ }^{3}$ In the new Unemployment Act, in the first year 70 per cent of the last wage was paid instead of 80 per cent, and for a further year the unemployed might have received 70 per cent of the minimum wage that was called as the social minimum below which no income is supposed to fall. When this benefit ended, unemployed persons were supposed to rely on social assistance.
} 
table, government spending on passive measures includes unemployment compensation and early retirement schemes.

Table 2.1: Public Expenditure on ALMPs in EU Countries, 1994

\begin{tabular}{|l|c|c|}
\hline Country & of GDP & of Government Spending on Passive Moasures \\
\hline Austria & 0.35 & 23 \\
Belgium & 1.39 & 47 \\
Denmark & 2.32 & 39 \\
Finland & 1.68 & 35 \\
France & 1.17 & 60 \\
Germany & 1.35 & 58 \\
Greece & 0.36 & 71 \\
Ireland & 1.48 & 46 \\
Italy & 0.93 & 90 \\
Luxembourg & 0.25 & 32 \\
Netherlands & 1.16 & 37 \\
Portugal & 0.73 & 63 \\
Spain & 0.60 & 18 \\
Sweden & 3.00 & 118 \\
United Kingdom & 0.53 & 38 \\
\hline
\end{tabular}

Source: $O E C D$ (1996).

The spending on ALMPs in the Netherlands is almost equal to EU average, however, the spending on passive measures is far less than the average. Therefore, it can be concluded that when compared EU averages the Netherlands is more likely to use ALMPs as an adjustment mechanism.

ALMPs can reduce the hysteresis effect by preventing or curing long-term unemployment. They also reduce the mismatch between labor supply and demand. Finally, by training ALMPs increase skill levels that will have positive effect on productivity.

The evidence supplied by micro-level studies in the Netherlands shows that targeting the medium-term unemployed (those unemployed for about six months) should be restricted to the disadvantaged groups among them, such as the low-skilled (Koning et.al., 1995). Some studies in the Netherlands support the conclusion that the net effects of ALMPs are highest for the most disadvantaged groups for which the gross effects are generally the lowest and examples are the low-skilled, the long-term unemployed, and older age groups (Koning et.al., 1996 and Koning et.al., 1995).

In sum, macroeconomic and microeconomic concerns are well-combined for the implementation of ALMPs in the Netherlands. The available microeconomic 
evidence suggests that the Netherlands is quite successful in reaching microeconomic objectives. Although there is some evidence for the success of macroeconomic objectives, the results are not as substantial as in the case of microeconomic objectives and, in fact, it is more difficult to measure the macroeconomic effects.

\subsection{Stylized Facts on the Dutch Labor Market}

\subsubsection{Labor Force and Participation}

Table 2.2 gives the absolute value of and change in both total population from 15 to 64 years and total labor force. As can be seen from the table below the increase in population between 15 and 64 years old shows a stable pattern until the late $1980 \mathrm{~s}$, then it is inclined to decrease and even a negative value is observed in 1992 . On the other hand, the change in labor force is not as stable as the change in population especially because of the introduction of some disability schemes. However, an increasing tendency in participation rate is noticed after the second half of 1980 s due to increasing female participation.

During the postwar period, the employment rate in the Netherlands relative to the population of working age seems to have been consistently low compared to that in an average OECD country (OECD, 1993). The most important factor behind the low employment rates is the low female participation rate. ${ }^{4}$ During many years tax and social security policy mainly encouraged the one-earner family. Two concrete measures favoring breadwinners in the Netherlands were that the income tax and social security treatment of work by a secondary earner in the married couple was in the 1970s relatively unfavorable (OECD, 1990b) and extended unemployment benefits paid only to breadwinners until 1985 (Aarts and Jong, 1992).

However, the polices during the 1970s and early 1980s were directed towards increasing the number of double-eamer families. Figure 2.1 and Table 2.3 gives the participation rates by age and sex groups for the Netherlands after $1983^{5}$.

\footnotetext{
4 Participation rate represents the labor force as a percentage of the population of working age.

$s$ In analyzing the participation rates and other labor market related figures, three data sources are employed, ILO, OECD, and EUROSTAT. ILO and OECD data are given in the appendix. The same trends, in some extent, are observed for all data sources but with different numbers because of the differences in the definitions. The differences in the trends will be noticed whenever necessary.
} 
can be categorized under three headings; information and counseling, direct placement, and routing (Employment Service,1991).

- By information and counseling to employers and to job-seekers, the best possible insight into labor market position and their job opportunities were given.

- Direct placement was performed by comparing and matching supply and demand.

- Routing was a complex combination of measures in a process of intensive placement activities, organized in close consultations with the employers in order to improve the possibilities.

The Netherlands was criticized by the International Monetary Fund (IMF) for its excessive emphasis on wage moderation in 1991 and IMF argued that more emphasis should be given on reducing government spending on social security and investing more in training and other infrastructural needs (Visser,1992:351-52). The framework for the labor market policies developed by the OECD (OECD,1990a) and endorsed by OECD Labor Ministers in 1992 recognized the role that active labor market policies can play in facilitating labor market adjustment (OECD,1994b). The broad policy recommendation which emerged from this framework is to shift labor market expenditures to active measures which mobilize labor supply, improve the quality of labor force, and strengthen the search process in the labor market. As compared the other member countries of $\mathrm{OECD}$, total labor market expenditures as a percentage of GDP went down in the Netherlands between 1985-1992 although an increase in the share of the active labor market policies was observed.

In 1995, the Minister of Social Affairs and Employment (SOZAWE) presented a policy document on increasing flexibility in the labor market (Pascoe,1996:8). Although the employment trends will be discussed in the next section, it is meaningful to present the main provisions of this policy recommendation. The major points of this policy document can be summarized as

- an increase in an employee's probationary period from two months to six months,

- temporary contracts to have a maximum duration of two years, after which, in most cases, the employee should be offered a permanent contract,

- redundancy terms to remain subject to the adjudication of the employment office,

- temporary job agencies to be required to place employees on a normal contract after six months of continual employment,

- a minimum call-out of three hours for temporary agencies. 
According to this policy prescription, globalisation, technological development, short production cycles and the rapidly changing demands of both employers and the working population are all factors forcing changes in the way work is organized (Pascoe,1996:8). Moreover, it was argued that these policies toward increasing flexibility met the needs of modern society and would help to lower unemployment.

Another recent debate is related with the effects of Economic and Monetary Union (EMU) on labor markets. According to a report prepared by Ministerie van Sociale Zaken en Werkgelegenheid (Ministry of Social Affairs and Employment$\mathrm{SZW}$ ), it is predicted that EMU leads a higher growth and improvement of the employment position $(S Z W, 1996)$. Higher economic growth may lead to a higher demand for labor and hence lower unemployment unless the supply of labor increases as well. However, there may be some negative side effects caused by EMU; it may enhance the unemployment problem, moreover, it limits the possibilities of policy makers to deal with the problem. The nominal exchange rate as a policy instrument cannot be used anymore to deal with shocks. This disadvantage causes shocks to increase the level of unemployment. Another problem is related with competitiveness; external role of EURO may force its external exchange rate up so that competitiveness of the whole European Union (EU) is put in danger. In some instances, it may cause extra wage demands because of increased transparency of markets that do not harmonized with the productivity level, and this may cause a decrease in the degree of competitiveness and higher unemployment (SZW,1996:10).

One of the most important tools that serves as an adjustment mechanism is active labor market policies (ALMPs). ALMPs can be divided into five categories: temporary job creation, training, job search assistance, wage subsidies for regular employment, and assistance for those starting their own enterprises (OECD,1993). Only the first one is unambiguously a separate state within the labor force. Trainees are arguably out of the labor force altogether whilst the availability of job search assistance, wage or self-employment subsidies do not constitute a separate state into which the unemployed are placed, but rather act to increase transition probabilities into regular or self-employment. The Netherlands is especially successful in the implementation of temporary job creation. In order to assess the importance given to ALMPs, Table 2.1 summarizes public expenditure on ALMPs in EU countries. In this 
Table 2.2: Total and Economically Active Population in the Netherlands,

1983-1995 (Thousands)

\begin{tabular}{|c|c|c|c|c|c|}
\hline Years & Ropulation & SCrange in Rqulation & Iabor & SCharge in Ldbor & Participation Pate \\
\hline & $15-64$ years $(000)$ & (15-64years) & Force $(000)^{1}$ & Eorce & \\
\hline 1983 & 9763 & & 5618 & 3.0 & 49.9 \\
\hline 1984 & 9886 & 1.3 & 575 & 1.7 & 50.2 \\
\hline 1985 & 9985 & 1.0 & 5725 & 0.2 & 49.7 \\
\hline 1986 & 10099 & 1.1 & 5087 & 2.8 & 50.4 \\
\hline 1987 & 10137 & 0.4 & 6500 & 10.4 & 55.2 \\
\hline 1998 & 10006 & 0.7 & 624 & 0.4 & 55.0 \\
\hline 1989 & 10260 & 0.5 & 6609 & 1.3 & 55.3 \\
\hline 1990 & 10324 & 0.6 & 6872 & 4.0 & 56.1 \\
\hline 1991 & 10417 & 0.9 & 6928 & 0.8 & 57.0 \\
\hline 1992 & 10094 & -1.2 & 7003 & 1.1 & 58.0 \\
\hline 1993 & 10359 & 0.6 & 7085 & 1.2 & 58.2 \\
\hline 1994 & 10427 & 0.7 & 7224 & 2.0 & 58.9 \\
\hline 1995 & 10472 & 0.4 & 7304 & 1.1 & 59.2 \\
\hline
\end{tabular}

Source: EUROSTAT (1983-1995)

1 Total Labor force is the sum of civilian labor force and armed forces.

2 Participation rate represents the labor force as a percentage of the population of working age.

Figure 2.1: Participation Rates by Sex in the Netherlands, 1983-1995

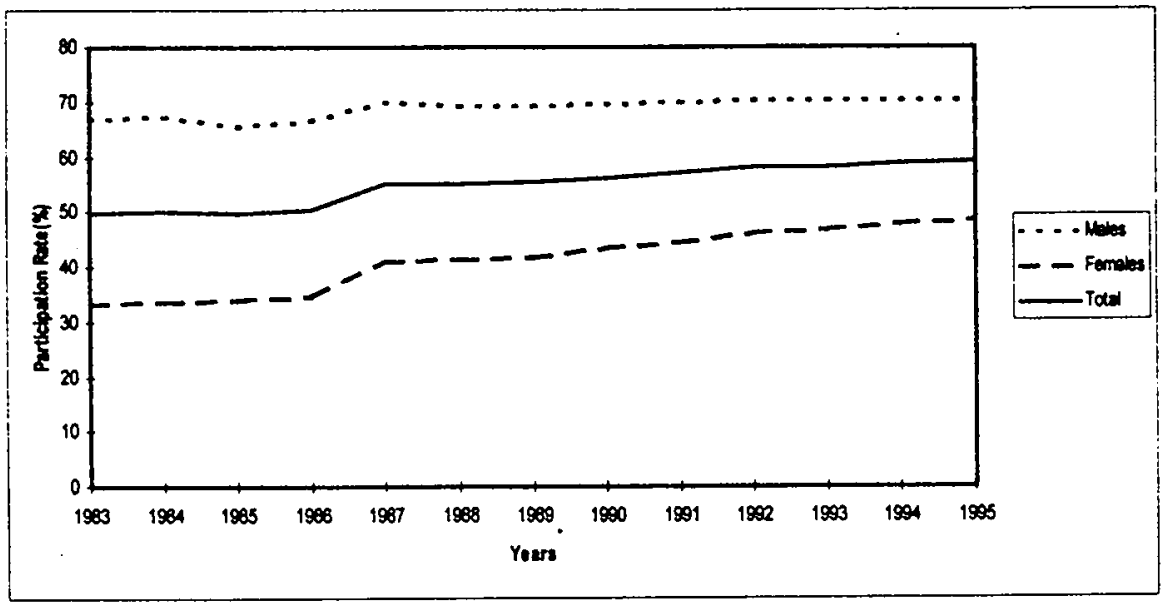

Source: Table 2.3. 
유 -

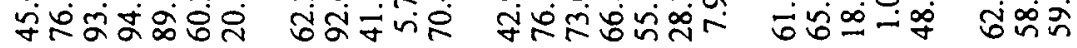

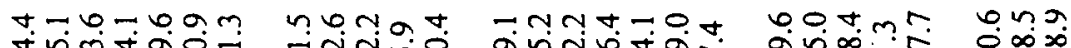

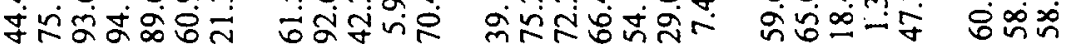

lon 0 on भing

กm

mmono

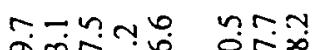

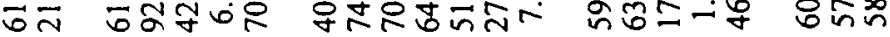

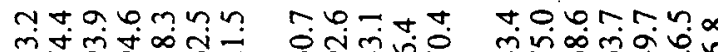

$\because r+\infty=0$

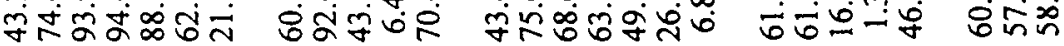

rmolina o-rao

$0 \infty \forall n-\forall n$

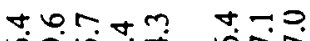

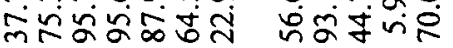

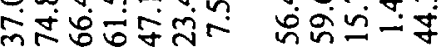

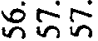

-

$\forall m+-n$

$\infty$ N.

ด. mi்

rnommen lom

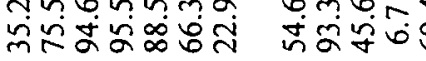

nontrman

nragra?

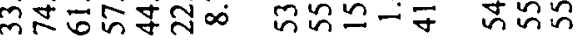

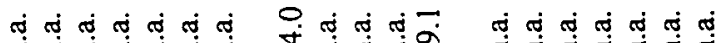

ஸ்

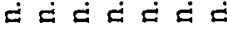

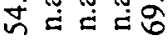

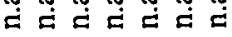

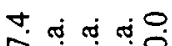

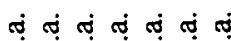

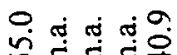

กู่

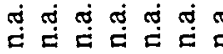

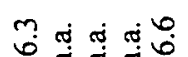

ه ه ه ه ه ه ه

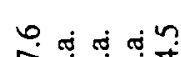

$0+$

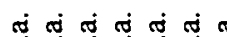

त) هึ่

त ه ه ه ه

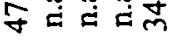

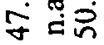

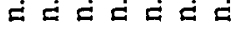

வ ه

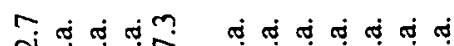

षे ه্் ه্்

r

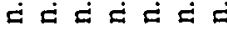

ป

भi

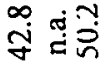

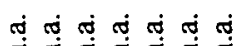

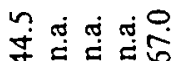

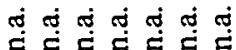

サั

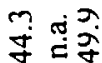

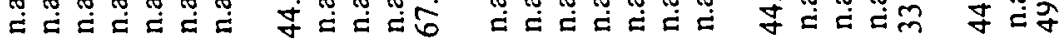

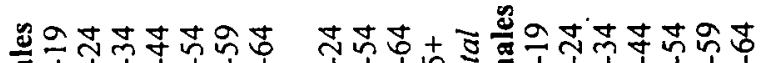

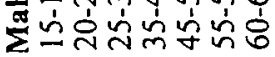

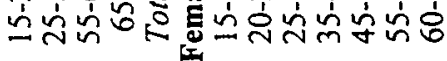

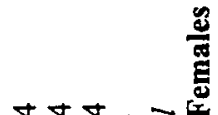


Participation rates for males show a gradual decline from 1975 until 1987, after 1987 it moderately starts to increase. On the other hand, the female participation rate increased tremendously especially in the second half of the 1980 s with the effects of policies adapted towards double-earner families. Total participation rates follow a similar pattern with that of the female participation rates. In terms of the age groups, the lowest participation rates for males is observed for the interval 15-24 possibly because of the schooling. The non-participation by older males is associated with the attractiveness of receipt of income from disability benefits and early retirement pensions. One of the most distinctive features of the female participation rates is the fact that they are higher in the intervals between 20 and 34 than the subsequent age interval of 35-54. Female labor force might prefer to be out of work after these ages because of cohort effect, marriage and pregnancy.

The household labor force data given in Table 2.4 and a report (1990) prepared by Ministerie van Sociale Zaken en Werkgelegenheid (Ministry of Social Affairs and Employment-SZW), support these views.

Table 2.4: Reasons Given by Non-Participants by Sex for not Seeking Work in the Netherlands in 1990 and 1996(\%)

\begin{tabular}{|l|c|c|c|c|c|c|}
\hline & & 1990 & & & 1996 & \\
\hline & All & Male & Frmale & All & Male & Female \\
\hline Ilness or Disability & 10.0 & 16.6 & 6.5 & 8.8 & 13.4 & 6.2 \\
\hline Personal or Family Responsibilities & 30.9 & 4.5 & 45.0 & 28.4 & 5.9 & 41.2 \\
\hline Education or Training & 15.2 & 23.6 & 10.7 & 10.3 & 15.2 & 7.5 \\
\hline Retirement & 38.1 & 49.7 & 31.9 & 45.0 & 58.1 & 37.6 \\
\hline Belief that no work is Available & 1.5 & 1.1 & 1.8 & 1.5 & 1.2 & 1.7 \\
\hline Other Reasons & 4.3 & 4.5 & 4.1 & 6.0 & 6.2 & 5.8 \\
\hline
\end{tabular}

Source: $\operatorname{HLFS}(1990,1996)$.

\subsubsection{Part-Time Employment}

Another characteristic of the Dutch labor market is the increasing share of part-time employment in total employment from the early 1970 s. Figures $4.2 \mathrm{a}, 4.2 \mathrm{~b}$, and $4.2 \mathrm{C}$ show the pattern of part-time employment in the Netherlands. By 1996 the share of part-time employment was higher than in any other EU country; over $15 \%$ for men and $60 \%$ for women. Moreover, the labor force participation by younger 
workers which largely offsets the low participation of the older age groups is often in part-time employment (OECD, 1993). However, the incidence of part-time employment is also unusually high at other ages, for instance $24 \%$ of employed males aged over 55 work part-time (OECD, 1992).

Figure 2.2a: Share of Part-Time Employment by Sex in the Netherlands, 1985-1996

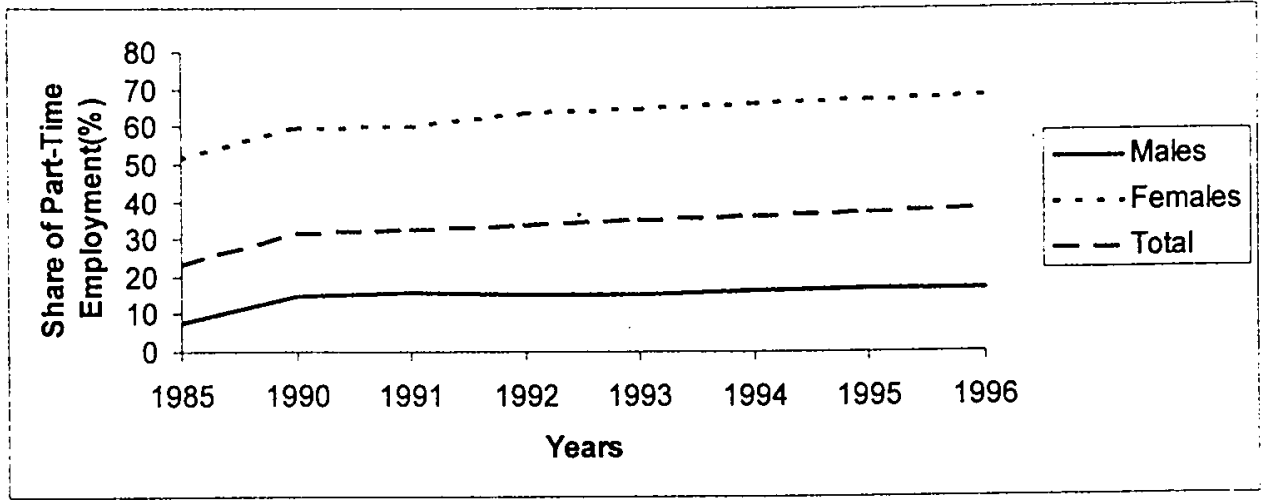

Source: EUROSTAT(1997).

Figure 2.2b: Males and Females Employed Part-Time as Percentage of All Employed Males and Females in the Netherlands, 1987-1996

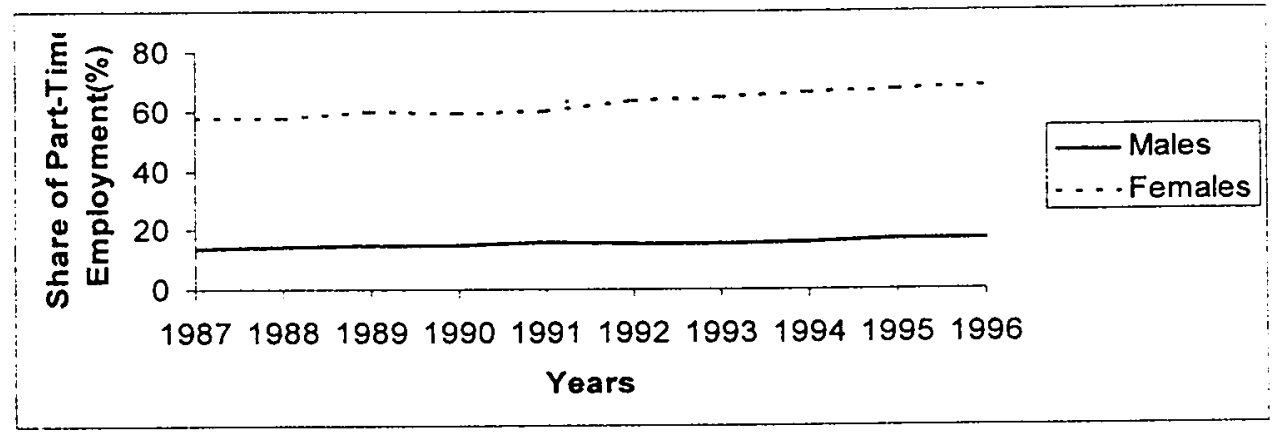

Source: EUROSTAT(1997).

According to some estimates, one out of three Dutch working population nowadays has no longer a full-time permanent job, $11 \%$ of people are on flexitime, and the number of people working through temporary employment agencies has been growing every month reaching about $2.5 \%$ of national employment (Pascoe, 1996:8). Temporary agencies are also becoming more involved in government policy to reduce unemployment. In 1995, the temporary agency organization ABU that represents 70 
temporary employment agencies covering about $75 \%$ of the market, called on the government to allow its members to mediate on behalf of easy-to-place job seekers and set up special projects for the less skilled (Pascoe,1996). The flexible working is not only confined to the bottom end of the job market but also an increasing number of young graduates are being attracted to the system (The Netherlander, 1996:9). However, there is a need for the improvement in the working conditions of temporary workers so that flexible work can better compete with the more traditional approach to employment and attract more highly-skilled workers.

Figure 2.2c: Females Employed as Percentage of All Part-Time Employed People in the Netherlands, 1987-1996

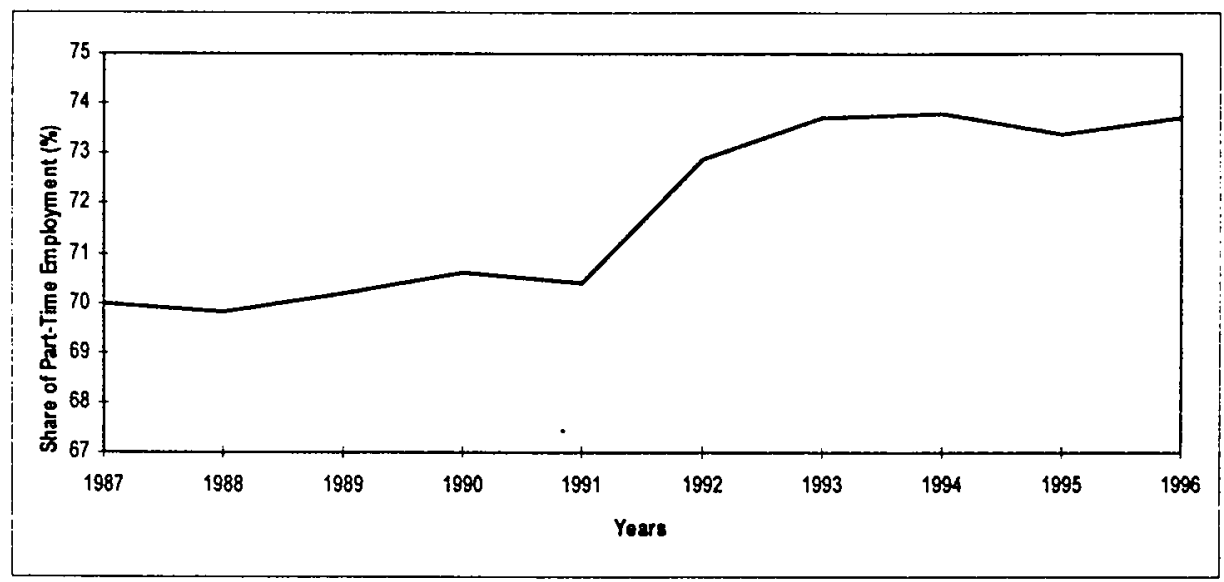

Source: EUROSTAT(1997).

\subsubsection{Unemployment}

The combination of somewhat low female participation rates, a very high incidence of part-time work, and very low participation by older age groups makes the Netherlands with the second lowest employment rate among OECD countries (OECD, 1993). However, the distinguishing character of the Netherlands is that it has a high level of GDP per capita meaning that the low rate of employment is associated with a high level of productivity in terms of GDP per man-hour worked.

The unemployment rate in the Netherlands approximately doubled once over 1973-1976 and again over 1979-1982 as can be seen in Table 2.5, Figure 2.3, and 
Figure 2.5. After 1982, buoyant employment growth began. Between 1983-1990, employment in persons grew by an average of $1.4 \%$ per year which compares with $0.9 \%$ in the EC, $1.0 \%$ in OECD Europe and $1.5 \%$ in the OECD as a whole (OECD,1991).

Table 2.5 demonstrates that unemployment is especially concentrated in particular groups. In the mid-1980s, unemployment of young persons aged between 15-24 was about 40\% of total labor force (OECD,1987) and in 1994 it is 1.7 times greater than the average unemployment rate.

The recent policies are directed towards the reintegration of unemployed members of the whole generation where an experience of sustained unemployment is prevalent, and to reduce unemployment among the young generation.

In most countries, the unemployment rate declines with age and reaches a minimum level at the ages 35-54 and rises again for older workers aged 55 to 59 (OECD,1995a).

Figure 2.3: Unemployment Rates by Sex in the Netherlands, 1983-1996

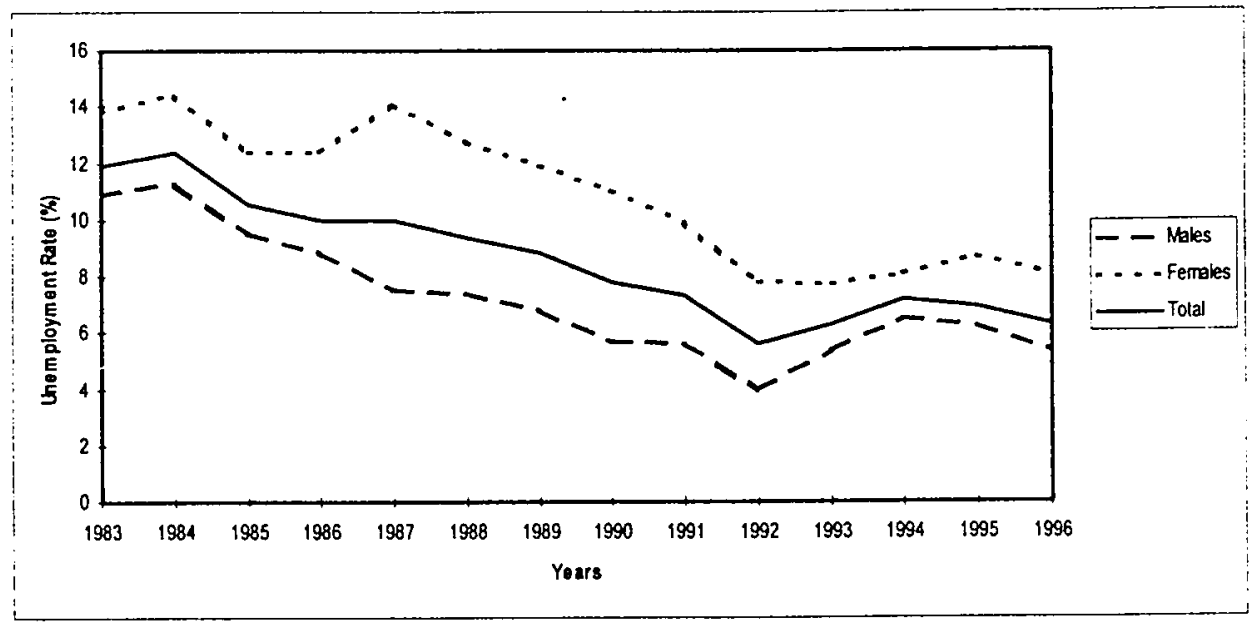

Source: Table 2.4 .

6 In analyzing the unemployment rates, two data sources are employed, ILO and EUROSTAT. ILO data is given in the appendix. The same trends, in some extent, are observed for both data sources but with different numbers because of the differences in the definitions. The differences in the trends will be noticed. 


\begin{tabular}{|c|c|c|c|c|c|}
\hline 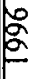 & 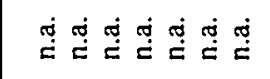 & 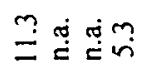 & 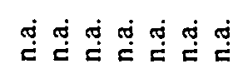 & 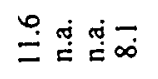 & 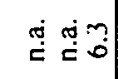 \\
\hline 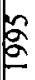 & 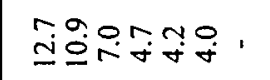 & 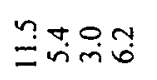 & 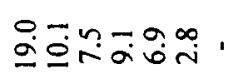 & $\stackrel{\infty}{\dddot{i}} \underset{\sim}{\sim}$ & $\overline{\underline{\Delta}} \overline{\dot{0}} \hat{0}$ \\
\hline i & 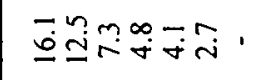 & 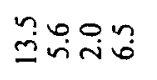 & 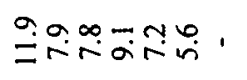 & $\stackrel{\infty}{\infty} \underset{\infty}{\infty}$ & $\stackrel{m}{=} \underset{0}{n} \mathfrak{n}$ \\
\hline$\tilde{2}$ & 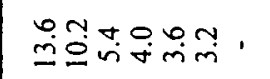 & $\dddot{\eta} \dot{\nabla} \ddot{i} \dot{m}$ & 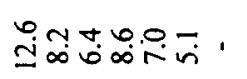 & 우요 & ñ. \\
\hline 2 & o̊o & 꾸ํ요 & 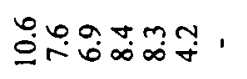 & 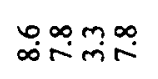 & क्ष \\
\hline 12 & 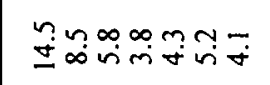 & 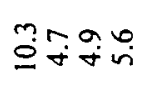 & 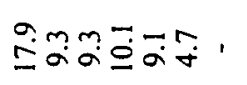 & 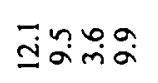 & $\stackrel{m}{=}$ \\
\hline R & 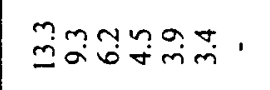 & 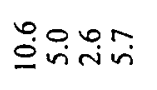 & 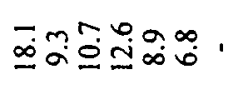 & 穴是岳是 & 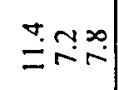 \\
\hline 2 & 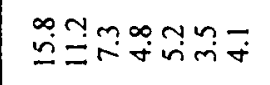 & 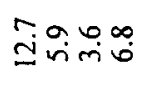 & 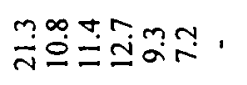 & 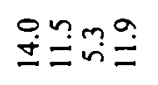 & $\ddot{m}+\infty \infty$ \\
\hline$:$ & 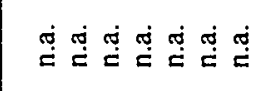 & 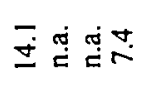 & 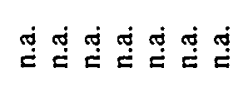 & 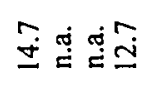 & $\begin{array}{l}\forall \\
\dot{ \pm}\end{array}$ \\
\hline R & 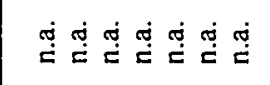 & 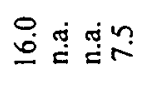 & 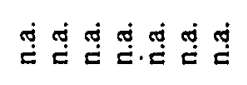 & 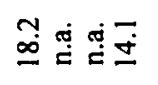 & 중유. \\
\hline$?$ & 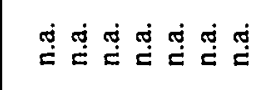 & 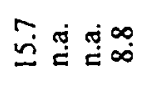 & 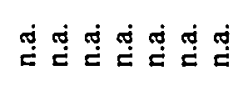 & 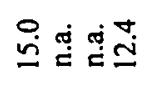 & $\begin{array}{l}\forall \\
\sim\end{array} \stackrel{\infty}{\infty} \stackrel{0}{0}$ \\
\hline ? & 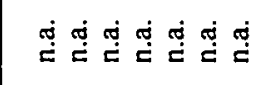 & 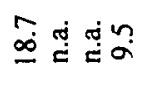 & 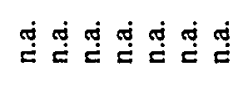 & 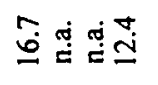 & 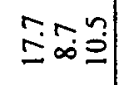 \\
\hline$?$ & 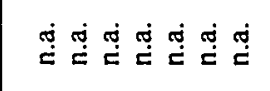 & 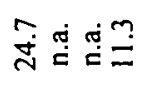 & 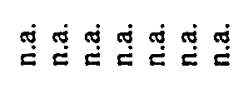 & 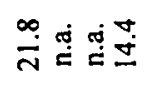 & 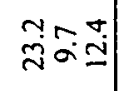 \\
\hline 6 & 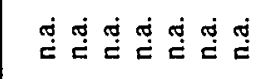 & 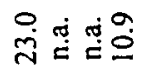 & 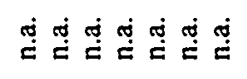 & 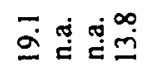 & $\ddot{\vec{n}} \nabla: \vdots$ \\
\hline & 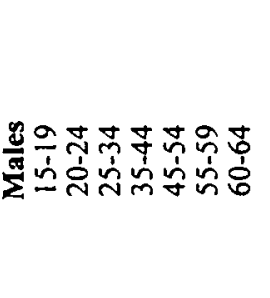 & \multicolumn{2}{|c|}{ 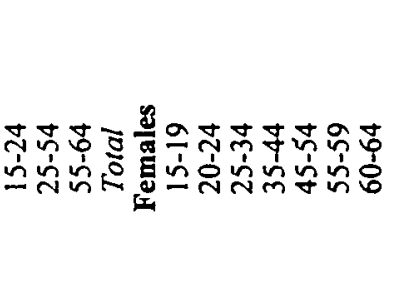 } & \multicolumn{2}{|c|}{ 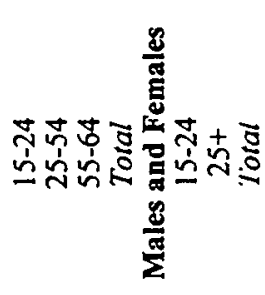 } \\
\hline
\end{tabular}


However, in the Netherlands the unemployment rate for older workers is higher than for prime-age workers and since participation rates at older ages are low, older workers constitute a low proportion of all unemployed. Moreover, among those who become unemployed, the incidence of long-term unemployment is high compared to other countries (OECD,1987 and 1988).

While older workers rarely become unemployed in the Netherlands, it is difficult for them to find a new job. In 1986 and $1987,75 \%$ of the unemployed aged 55 and over were long-term (OECD,1987 and 1988). This indicates that there are barriers to employment for this group resulting from either the long insurance benefit duration for older workers or a discriminatory attitude by employers. The second important conclusion drawn from Table 2.5 and Figure 2.3 is the higher unemployment rate of females than males. However, there is an interesting point in the female unemployment rates. They are less volatile to the economic crisis. In the second oil crisis, male unemployment rate almost doubled from $3.6 \%$ in 1979 to $7 \%$ in 1981 whereas the increase in female unemployment rate was not so tremendous, $4.9 \%$ in 1979 and $6.8 \%$ in $1981 .^{?}$

The causes of high unemployment rates can be listed as excessive wage demands, non-wage labor costs, labor market imperfections, labor force growth, and restrictive macroeconomic policy. According to Neubourg (1990), the last two factors are as important as the others since labor force growth is higher in the Netherlands than any other European country. There has been concern that long-term unemployment, after an initial decline from a peak reached in 1986, has responded weakly to the fall in unemployment in general as can be seen in Figure 2.4. In 1989, approximately $50 \%$ of the unemployed in the Netherlands had been unemployed for a year meaning that half of the unemployment is long-term.

An interesting recent development is the analysis of traditional unemployment/vacancy data from a search theoretic point of view. This is done in the Netherlands by Ours (1991) by estimating a so-called matching function. The specified matching function makes it also possible to analyze the efficiency of the Dutch labor market in different periods.

\footnotetext{
${ }^{7}$ Such a situation might be a result of job seggregation.
} 
A conventional result of this approach is the indication that the labor market in the 1960s was more efficient than it was in the 1970s. A remarkable result, however, is the conclusion that with a higher level of unemployment and a lower level of job vacancies, the labor market in the 1980 s is apparently as efficient in generating a flow of filled vacancies as it was in the 1970 s. Figure 2.5 shows the number of unemployed persons and vacancies.

Figure 2.4: Duration Structure of Unemployment in the Netherlands, 1990-1996

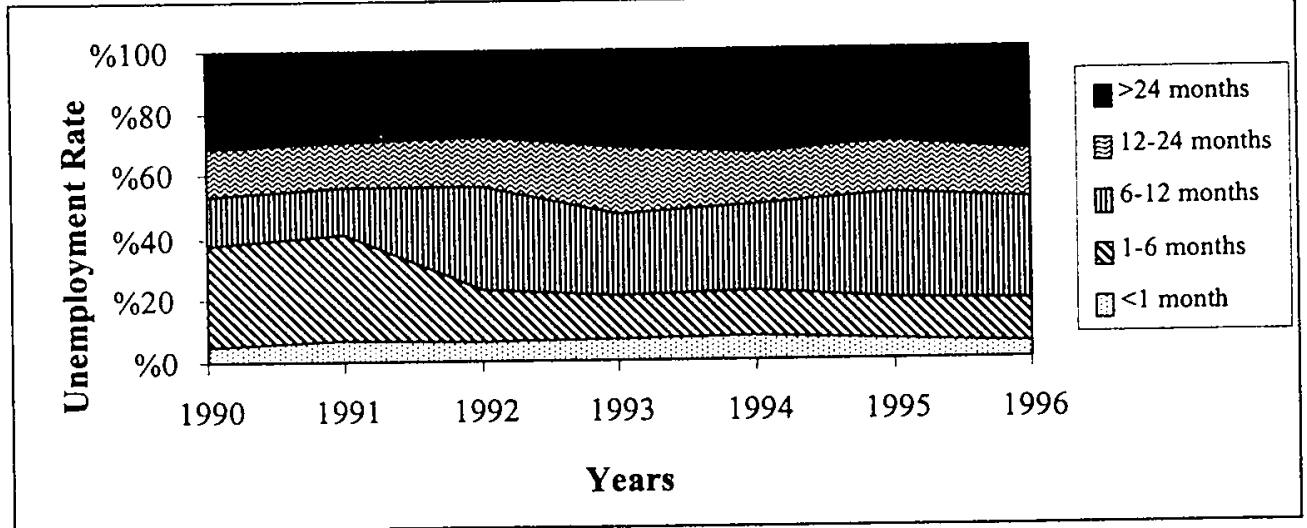

Source: HLFS (1990-1996).

Underlying the numbers in the unemployment/vacancy figure are thus special factors with a political loading.

- In some parts of the country, no matter how small a country the Netherlands is, there is a relatively strong regional component in the unemployment figures. ${ }^{8}$ In some areas many job seekers are frustrated in their efforts to find a job because of a structural shortage of demand for labor.

- There is a high level of unemployment in the Netherlands among ethnic minorities, particularly among the young people in the larger cities. ${ }^{9}$

- At all levels of education there are gaps and discrepancies between the qualifications required and those held by the unemployed (OECD, 1993). This is

\footnotetext{
${ }^{8}$ For the regional unemployment figures see Neubourg (1990).

${ }^{9}$ For the detailed analysis of demographic characteristics of unemployment, see Ermisch (1995).
} 
the case in technical fields as well as in the service occupations. A striking relative deterioration in the position of young job-seekers with an academic training has been reported in recent years (OECD, 1993).

- The highest risks of long-term unemployment are carried by drop-outs from lower vocational training, closely followed by drop-outs from secondary education and school-leavers with a preuniversity education (OECD, 1993).

Figure 2.5: Unemployed and Vacancies in the Netherlands,

\section{0-1995}

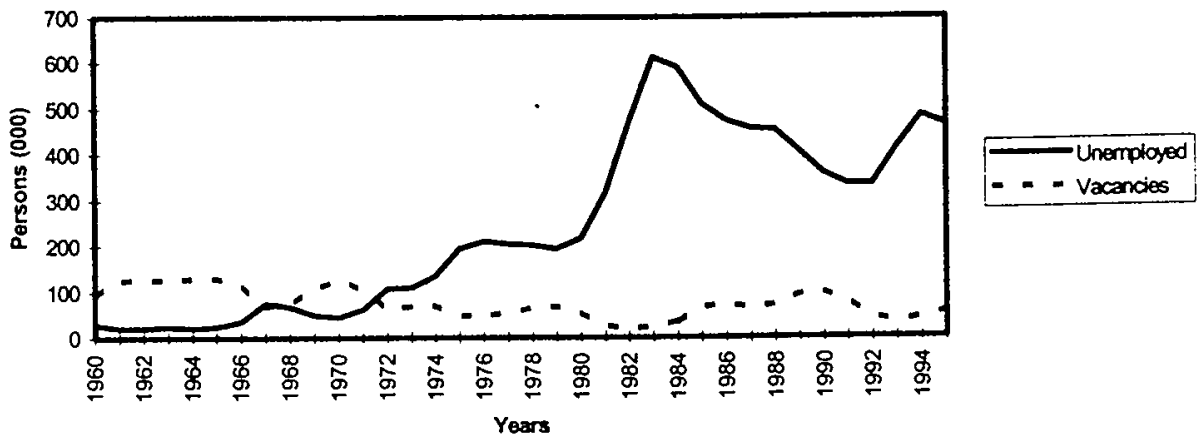

Source: $C B S$.

The last three factors show that training is increasingly necessary in the shaping and the formulation of the Dutch labor market policy. In this sense, the target groups should be long-term unemployed, minorities, and young people. 


\subsection{Trends in Employment and Wages in Dutch Manufacturing Industry}

The section is confined to manufacturing industry instead of aggregates since this study essentially investigates the wage transmission mechanism in the manufacturing industry.

\subsubsection{Employment}

The employment shares of industries in the Netherlands are presented in Table 2.6. From 1981 to 1994 , the share of manufacturing in total employment constantly decreased from $20.5 \%$ to $16 \%$ while the relative share of service sector employment was increasing as in other industrialized and semi-industrialized economies.

Table 2.6: The Employment Shares of Industries in the Netherlands, 1981-1994

\begin{tabular}{|c|c|c|c|c|c|c|c|c|c|c|c|}
\hline & 198 & 1983 & 196 & 198 & 19 & 199 & 1900 & 1991 & 1992 & 1998 & 1904 \\
\hline Agriolthre, hrting frostry, and fistiry & 5.31 & 5.4 & 5.2 & 4.79 & $4.7 \pi$ & 4.65 & 4.5 & 4.49 & 3.91 & 3.89 & 3.95 \\
\hline Mring qeonyirg & 0.17 & 0.16 & 0.22 & 0.22 & 0.22 & 0.19 & 0.17 & 0.21 & 0.14 & 0.18 & 0.15 \\
\hline Menfecting & 20.41 & 19.7 & 19.31 & $18 . \circledast 8$ & 18.39 & 18.72 & 18.64 & 17.93 & 17.90 & 16.5 & 16.06 \\
\hline Electricity, ges, & 0.92 & 0.94 & $0 . \infty$ & 0.87 & 0.78 & 0.75 & 0.6 & 0.6 & $0 . \oplus$ & 0.6 & 0.0 \\
\hline Constation & 9.24 & 7.6 & 7.50 & 6.46 & 6.58 & 6.45 & 6.43 & 6.41 & 5.84 & 5.98 & 5.87 \\
\hline Trode, restarats, & 17.83 & $17 . \oplus$ & 17.2 & 16.64 & 16.83 & 16.86 & 17.37 & 27.46 & 17.37 & 17.69 & 18.34 \\
\hline Trancpat, strrage, cumurication & 6.3 & 6.5 & 6.27 & 6.0 & 6.0 & 6.17 & 6.01 & 6.18 & 6.23 & 6.14 & 6.26 \\
\hline Elrancing iraxence, neel etate, busires services & 8.03 & 8.41 & $8 . \otimes 9$ & 9.24 & 9.83 & $9 . \oplus$ & 10.16 & 10.46 & 10.28 & 10.53 & 10.52 \\
\hline Connity, social, and persoral sevices & $31 . \infty$ & 33.5 & 33.35 & 3.59 & 36.31 & 3.86 & 3.07 & 3.47 & 34.6 & 3.26 & $\mathbf{5 . 4 3}$ \\
\hline ater ativities & 0.76 & 0.50 & 0.77 & 1.31 & 0.35 & 0.49 & 0.211 & 0.72 & 3.5 & 2.86 & 2.73 \\
\hline
\end{tabular}

Source: ILO(1990,1995).

Figure 2.6: Employment in the Dutch Manufacturing Industry, 1970-1993

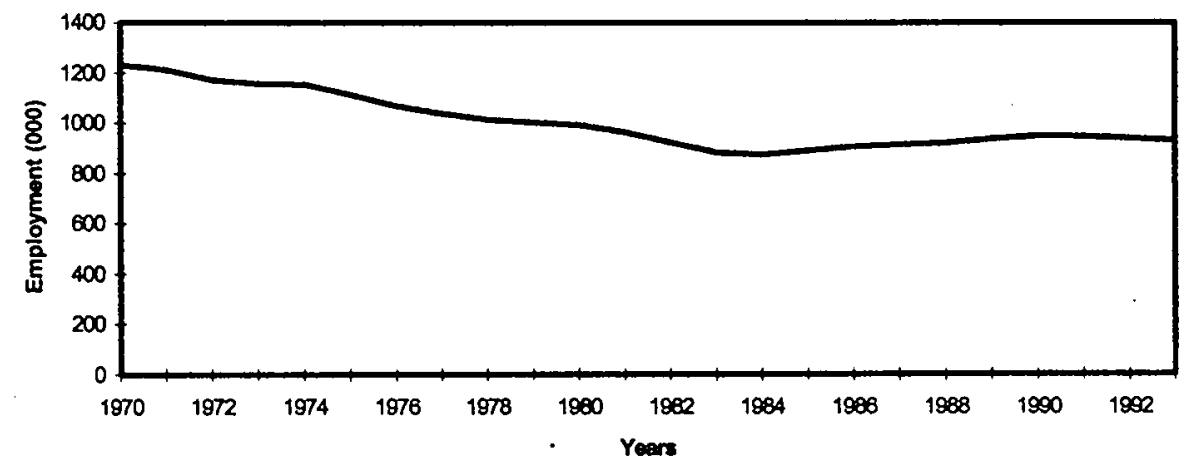

Source: OECD (1995b). 
While employment share of the Dutch manufacturing industry declines, the total number of workers in the manufacturing industry also decreases between 1970 and 1993 as illustrated in Figure 2.6.

Total number of workers in manufacturing industry steadily decreases until 1985 and begin to increase after the second half of 1980 s yet its level is still $25 \%$ less than the level in 1970 .

\subsubsection{Wages}

Table 2.7 shows the wage structure in the Dutch manufacturing industry. The lowest-wage industries are manufacture of wearing apparel (322) and manufacture of footwear (324). ${ }^{10}$ On the other hand, the maximum wages are paid by petroleum refineries (353) and manufacture of products of petroleum and coal (354).

The last column of Table 2.7 demonstrates the relative deviation which is calculated as the ratio of standard deviation to mean wage. Relative deviation is used as a measure for wage dispersion. The wage dispersion in Dutch manufacturing industry continuously increases for the period 1970-1994 except in 1971 and the rate of increase is especially higher after 1981.

On the other hand, real hourly wages in the Dutch manufacturing industry shows a stable trend of increase in the period of analysis as can be seen Figure 2.7. In 1993, real hourly wages are 1.6 times larger than the level in 1970. However, there are some years with a decrease in real hourly wages, especially in the period after the second oil crisis, i.e. between 1981-1985.

\footnotetext{
${ }^{10}$ For the International Standard Industry Codes (ISIC), see the appendix.
} 


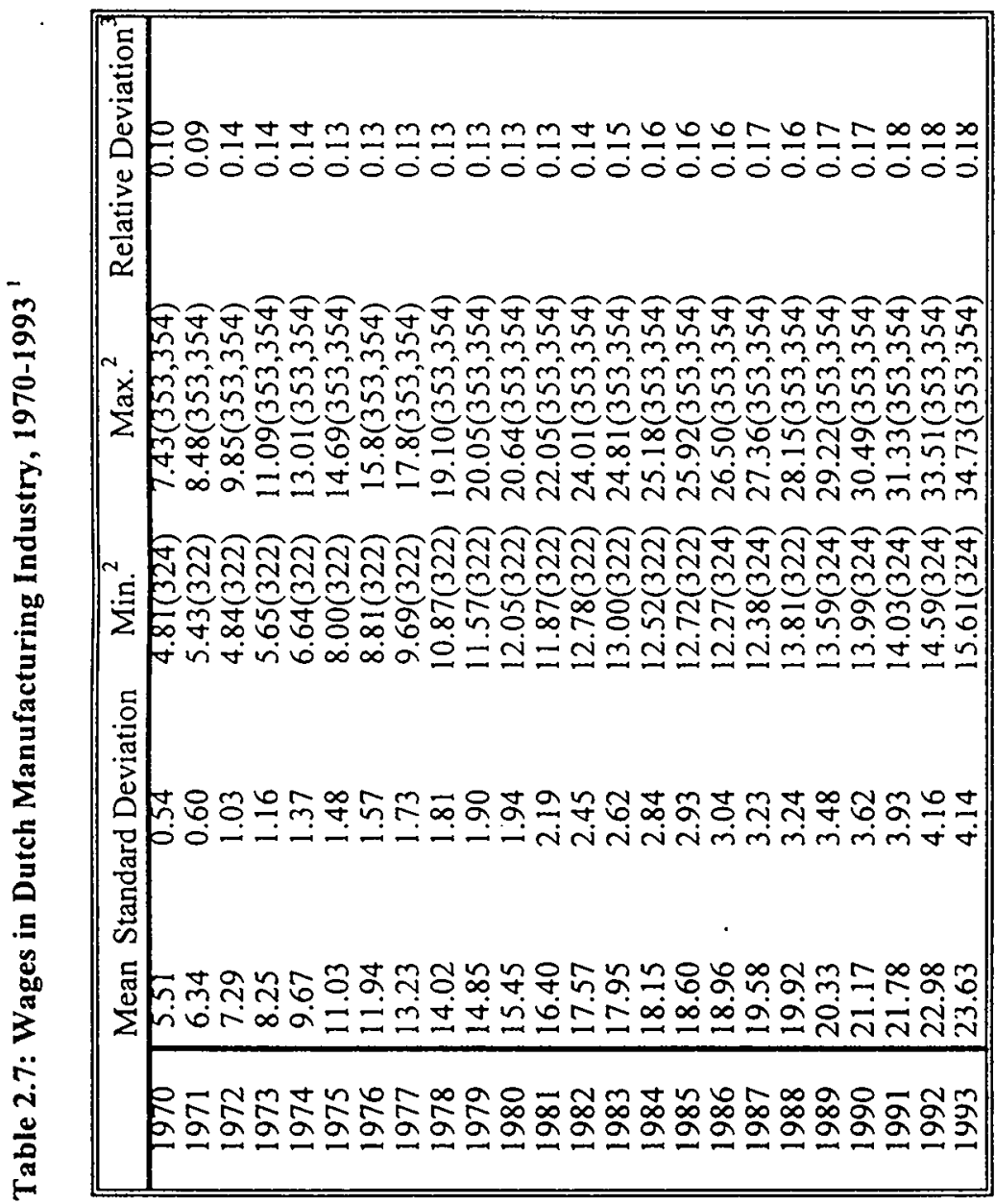




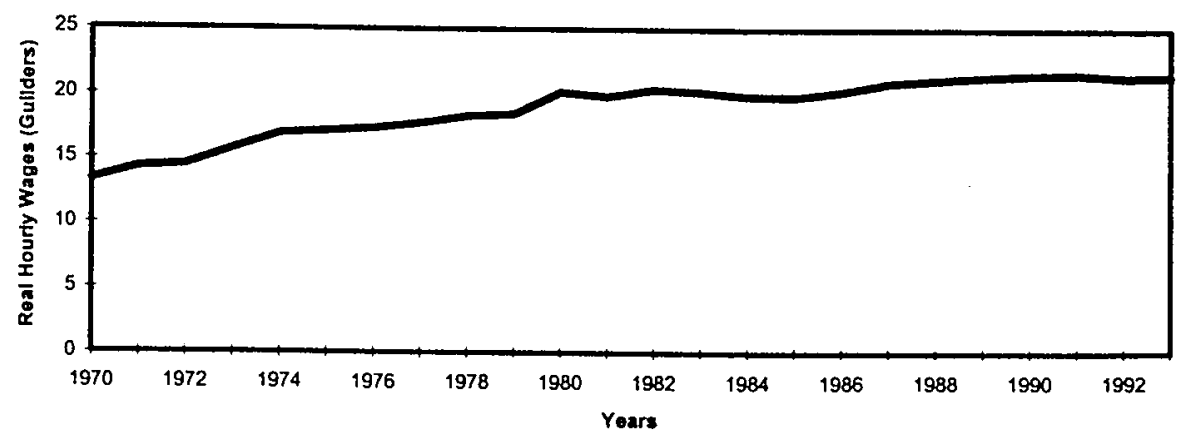

Source: OECD (1995b).

Summarizing, employment share of manufacturing industry in the Netherlands is decreasing. The real hourly wages show an increasing trend while the the wage dispersion also increases between 1970 and 1994.

\subsection{Institutions in the Dutch Labor Market}

In this section of the study, institutions in the Dutch labor market, namely trade unions and employers associations will be analyzed in a historical context for the postwar era.

\subsubsection{Post-War History of the Dutch Trade Union Movement}

By 1900 , the Dutch trade union movement, which began as a loose collection of largely illegal small organizations, had grown into a firmly rooted social institution capable of contributing significantly to the nation's development (Voorden,1992:305). "Organized labor played a determining role in establishing the welfare state and they are taking more and more responsibility for society as a whole. With respect to developments within the trade union movement, the post-war era can be divided into three subperiods even though the borderlines are not always very clear (Visser,1989a and Berg, 1995).

\footnotetext{
"For the chronology of the Dutch trade union movement, see the appendix.
} 
- 1945-1959, a period characterized by very centralized decision-making in which the power was shared between government, employers associations, and the union federations; union membership rose almost continuously, with a temporary stagnation towards the end of the 1950 s. In this period, membership rates were, however, very low.

- 1959-1975, a period in which the decision process gradually shifted to industry level, while the unions took the greater part of the power in the industry-level bargaining and there was a steady rise in union membership.

- 1975-1990, a period in which the unions lost their superior position as a result of the longest lasting recession since the war. For the first time, the size of the union movement decreased substantially until 1986 after which it regained its strength.

In order to rebuild the Dutch economy after the war, the government, trade unions and employers associations were prepared to work closely together. The social and economic policy was centralized as explained in the beginning of this chapter. The main result of the new legal framework was the complete dominance of central organizations of employers and unions. Since only the recognized federations had a right to take a part in decision-making process, it isolated all other unions. Stimulated by a series of post-war political coalitions between socialists and confessional parties, cooperation among three national federations, namely Netherlands Verbond van Vakverenigingen (Dutch Confederation of.Trade Unions-NVV), Christelijk Nationaal Vakverbond (Protestant National Trade Union Confederation-CNV), and Katholieke Arbeidersbeweging (Catholic Labor Movement-KAB) grew steadily after the war. This cooperation was especially evident at the national level in the Foundation of Labor and SER, however it underwent a severe setback in 1954 when an episcopal guideline prohibited Roman Catholics from joining non-Catholical organizations and condemned socialist, humanist, and liberal ideas as well as the associations they inspired (Voorden,1992:310). Although the cooperation among three national federations existed, pluralism remained the characteristic of the Dutch union movement. $\mathrm{CNV}$ and $\mathrm{KAB}$ already in 1946 reached their prewar levels of membership again; furthermore for the first time the confessional federations together had a higher membership than the size of the socialist NVV and would keep that position until 1972 (Visser,1989a). Just after the war, NVV was in a close competition with another socialist federation called as Eenheids Vakcentrale (United Centre of 
Trade Unions-EVC), the latter had even more members than the former in 1945 (Visser,1989a). Between 1945 and 1947, these two confederations attempted to realize a merger but it failed. By subscribing to the principles of the Foundation of Labor, the NVV had committed itself to the acceptance of the capitalistic structure of the economy, and to maintenance of industrial peace. Moreover, by exchanging its socialistic principles for social democratic principles, the NVV hoped to attract more workers, irrespective of political or religious concerns (Windmuller, 1969:350).

NVV, KAB, and CNV supported the policy of wage restrictions, as this not only served the common interest but also their own; they were recognized as official advisors to the government, and the extension of collective agreements expanded enormously, therefore their position strengthened (Voorden,1992:311). Between 1945 and 1958, the three major trade unions went along with the strictly guided wage policy, especially NVV was very much in favor because of its solidarity principle, equal proportional pay rises for everyone (Berg,1995:55). For the whole period 19451959, the union movement had grown very rapidly as can be seen in Table 2.8. The first post-war years witnessed an explosive growth with an annual average of $11.6 \%$ between 1945 and $1948 .{ }^{12}$ In the decade 1949-1959 this overall growth slowed down to about $1.6 \%$ annually and the membership of three trade unions increased in these years as presented in Table 2.9.

Windmuller (1969:354-56) regards 1959 as a milestone in the post-war industrial relations, for the sake of solidarity with the weak sectors the Partij van de Arbeid (Labor Party-PVDA) and NVV had defended the guided wage policy for a long time. In 1959, when a new government was formed without PVDA, a change towards more free wage formation is observed.

Differentiation in terms of employment had to be reached by linking the wage development in a certain industrial sector to the rise in productivity in that sector. By forbidding the wage increases to be passed on to the consumer, the government kept pursuing an active price policy. While the negotiations shifted more towards the industrial level, the final review still remained centralized at the Board of Government Mediators (Windmuller, 1969). Meanwhile, the labor market became extremely tight.

\footnotetext{
${ }^{12}$ However, the figures for this period are not very reliable.
} 
Table 2.8: Union Density Rates and Union Membership Developments in the Netherlands, 1946-1995

\begin{tabular}{|c|c|c|}
\hline & Union Density Rate & Annual Change in Union Membership \\
\hline 1946 & 40.40 & 20.70 \\
\hline 1947 & 39.40 & 9.00 \\
\hline 1948 & 39.80 & 5.80 \\
\hline 1949 & 40.80 & 4.70 \\
\hline 1950 & 42.00 & 4.80 \\
\hline 1951 & 37.10 & -10.00 \\
\hline 1952 & 37.70 & 3.40 \\
\hline 1953 & 38.50 & 4.40 \\
\hline 1954 & 38.70 & 3.50 \\
\hline 1955 & 38.90 & 3.10 \\
\hline 1956 & 40.40 & 6.10 \\
\hline 1957 & 39.40 & -0.30 \\
\hline 1958 & 39.00 & 0.20 \\
\hline 1959 & 39.10 & 1.40 \\
\hline 1960 & 39.40 & 3.30 \\
\hline 1961 & 39.10 & 1.40 \\
\hline 1962 & 38.40 & 1.20 \\
\hline 1963 & 38.50 & 2.40 \\
\hline 1964 & 37.30 & -0.80 \\
\hline 1965 & 37.00 & 1.60 \\
\hline 1966 & 37.60 & 3.40 \\
\hline 1967 & 37.40 & 0.50 \\
\hline 1968 & 37.10 & 0.70 \\
\hline 1969 & 36.20 & -0.20 \\
\hline 1970 & 34.90 & 2.50 \\
\hline 1971 & 34.60 & 1.30 \\
\hline 1972 & 34.50 & 0.90 \\
\hline 1973 & 35.00 & 2.90 \\
\hline 1974 & 34.60 & 1.00 \\
\hline 1975 & 34.90 & 2.30 \\
\hline 1976 & 33.90 & -0.20 \\
\hline 1977 & 34.10 & 1.60 \\
\hline 1978 & 33.70 & 0.60 \\
\hline 1979 & 32.80 & 0.50 \\
\hline 1980 & 31.30 & -1.50 \\
\hline 1981 & 29.30 & -2.20 \\
\hline 1982 & 27.70 & -2.20 \\
\hline 1983 & 26.00 & -4.10 \\
\hline 1984 & 24.70 & -2.80 \\
\hline 1985 & 23.90 & -1.30 \\
\hline 1986 & 27.50 & -0.30 \\
\hline 1987 & 25.60 & 1.20 \\
\hline 1988 & 25.50 & 2.30 \\
\hline 1989 & 26.20 & 3.50 \\
\hline 1990 & 24.00 & 2.42 \\
\hline 1991 & 25.00 & 3.25 \\
\hline 1992 & 27.00 & 3.90 \\
\hline 1993 & 28.00 & 2.09 \\
\hline 1994 & 28.00 & 1.60 \\
\hline 1995 & 29.00 & 1.39 \\
\hline
\end{tabular}


Table 2.9: Percentage Membership Share of Recognized Federations in the Netherlands,1946-1995

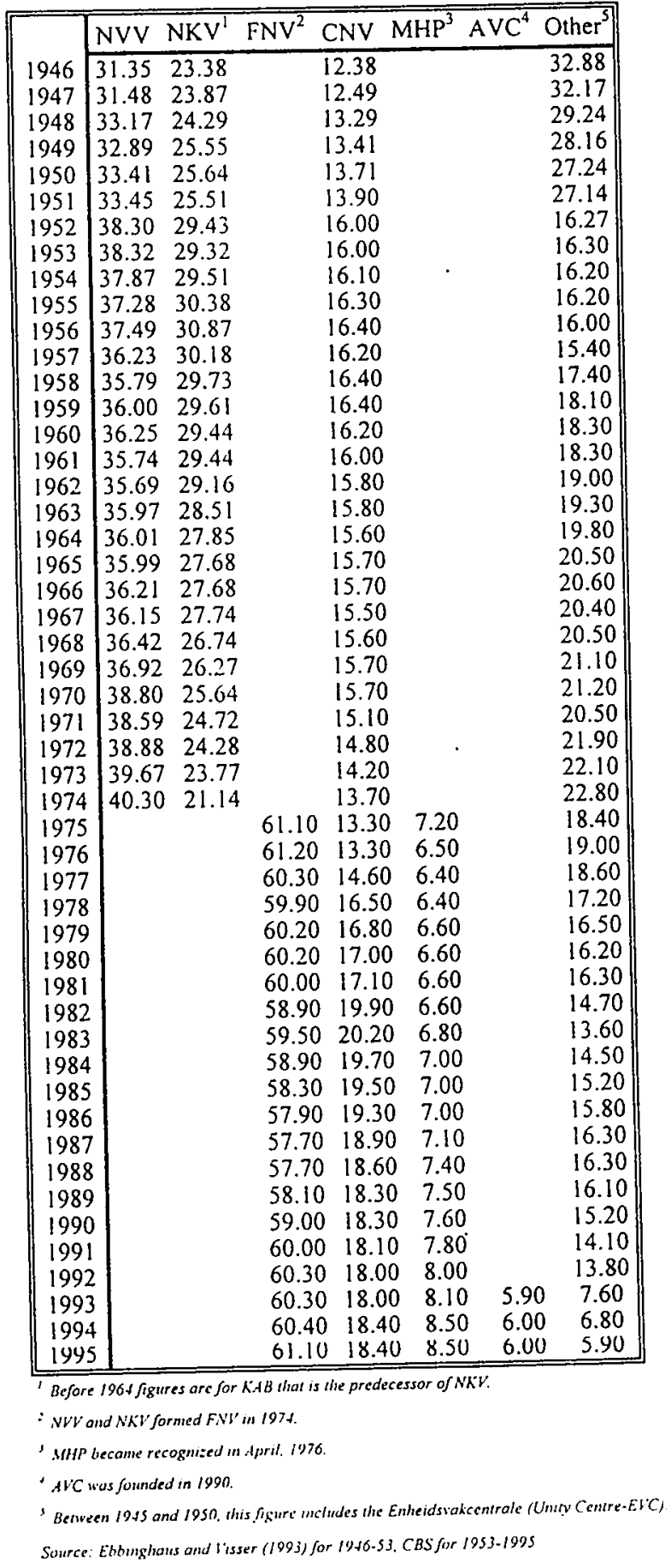


The shortage of labor gave the unions a strong bargaining position, leading to a reduction of the working week from 48 to 45 hours which immediately led to a rise in labor costs, a temporary decline in industrial production and export which caused government to intervene once again in the wage formation in 1962 (Windmuller, 1969:363).

Thus, the new wage policy was still dominated by centralization. Although there were other differentiations, the significant contrast to the previous period was that the bargaining parties did not abide by the rules. Although the affiliated unions felt passed over, they accepted the decisions of their federations instead of their members' demands (Voorden,1992).

At the end of 1967, parties in the Foundation of Labor agreed that the centralization should be replaced by the autonomous bargaining in each industrial sector (Windmuller, 1969:377).

The more relaxed labor market was giving the employers a bit more bargaining scope. Moreover, employers and unions both agreed that the wage gap between the strong sectors such as metal and chemical industry and the weaker ones such as textiles, clothing and shoe industry had become too large to justify the same wage increases (Berg, 1995:62). The Wage Determination Act was promulgated by the Parliament in 1970 after long discussions and protest of the union movement since the Minister of Social Affairs not only retained the power to issue a general wage control but also the right to interfere with separate collective labor agreements (Voorden, 1992:311). Thereupon, the NVV and Nederlands Katholieke Vakbeweging (Dutch Catholic Trade Union Federation-NKV) decided temporarily to resign from the SER and from the Foundation of Labor to protest the situation. ${ }^{13}$ This was the first sign of growing polarization between a large part of the union movement, the govermment and employers (van Voorden, 1992:312).

In 1960 s the union movement grew by $10.5 \%$ yet the labor force rose by $17 \%$, implying a decline in union density rate as shown in Table 2.9. When three Dutch union federations compared, the NVV achieved the highest rise in membership with $11.4 \%$ yet the CNV only increased by $6.4 \%$ while the NKV did not grow at all. In order to make the membership more attractive, it was recognized that the distance

${ }^{13} \mathrm{NKV}$ was founded in 1964 as the succesor of $\mathrm{KAB}$ and built the same organizational structure as the NVV (Windmuller, 1969). 
between the union leaders and members should be reduced. In the course of the 1960 s, this goal was realized in numerous ways. The unions realized that they had to go along more with the existing needs among their members, especially the unions in the growing sectors would gain from a more decentralized policy as they could press for higher demands than average (Windmuller,1969). The annual wage consultations changed into wage negotiations which was facilitated by the gradually more differentiated wage policy (Berg and Groot,1992). In 1960s, unions started to strike again. The workers resisted against wage restraint introduced on them in the first half of the decade and the unions gradually had to call for strikes in the second half of the decade. Another way to increase the attentiveness of the union movement was by means of merger. Several unions joined forces in the beginning of the 1970 s among which the NVV and NKV that was Socialist and Catholic Industrial Union was formed by the unions of miners, metal, textile and factory workers in 1972 (Albeda,1989). Membership rates showed an improvement in the first half of the 1970 s especially because of the more active attitude of the NVV. The membership increased only at the NVV whereas the CNV and the NKV fell back by about $5 \%$ and $11 \%$ respectively. More importantly, after 1972 the confessional federations would remain smaller than the NVV because of the widespread populism of socialist ideas in these years. In 1974, a number of white collar unions joined to form a new national federation, Vakcentrale voor Middelbaar en Hoger Personeel (Federation of Trade Unions for Staff and Managerial Personnel-MHP) which was admitted to the SER in 1976.

The third subperiod of Dutch trade union movement began in 1975 just after the first oil crisis. For the Dutch labor force, the main impact of crisis was the rise in structural unemployment that required a change in union policies. During 1975 and 1976 there was a certain shift of power within the union movement. Since the merger between the NVV and the NKV also commenced from 1976, the new Federatie Nederlandse Vakbeweging (Federation of Dutch Trade Unions-FNV) was by far the strongest center and while the NVV and the NKV were heading for a final merger in 1982, the distance between the FNV and the CNV became greater (Berg,1995:68). The primary reason for this was that the CNV remained more moderate in its views regarding cooperation with the employers while the FNV underwent an ideological reorientation towards more socialistic reforms for which a more regular use of strikes were permitted (Berg,1995). After 1976, the Dutch trade union movement was forced 
back on defense since as the business profits decreased ever faster and the unemployment rate was increasing the bargaining power of unions also decreased. The union movement began to realize that moderation of its wage demands became a necessity for two reasons; to improve the firms' profits which should slow down dismissals in the era of worldwide crises, and out of solidarity with the non-active population whose social benefits were linked to the minimum wage. If the wage increases became too high, this linkage would be endangered. In 1978, unions were willing to accept a wage sacrifice of $1.5 \%$ if they could reach agreements on the preservation of jobs to be accomplished by early retirement, and by a transition to five shifts in the continuous industry (Groot and Berg,1994). Until 1982, the unions still aimed at preserving the spending power by holding on to their acquired right of automatic wage indexation. However, in this year unemployment increased even faster so that unions could not reach the wage targets set. The unique strategy became the preservation of employment to be achieved by work-sharing through shorter working hours (Voorden,1992). There were two reasons to give priority to employment policies. First, the union movement lost much of their bargaining power because of the increasing unemployment. Second, it was realized that the social security system was endangered as the ratio between the employed and people receiving some sort of social benefit had declined from 7 to 1 in 1970 to 3 to 1 in 1981 (Visser, 1989b). The decentralization developed further remarkably after 1982. Negotiations take place at industry level, but ever more arrangements are left to be elaborated at the company level, where unions have little impact (Berg, 1995:75). Up to 1987 , the union movement lost more members than it enrolled new ones as presented in Table 2.10. In the second half of the decade, total membership begin to rise again with the upswing of business cycle and rising employment.

By the beginning of 1990 s, a debate was in progress about how to make the structure of the trade union federations more efficient (Voorden,1992:312). It did not seem to make sense that several unions in a single industry should belong to the same federation. A fourth national federation, Algemene Vakcentrale (General Trade Union Federation-AVC) was established in 1990. Ambtenarencentrum (the Civil Servants' Center- $A C$ ) took the initiative. In order to legitimate its existence, the AVC sought to differentiate itself from each of three older national federations by proclaiming itself nonsocialist, nonconfessional, and not confined to middle and higher personnel (Voorden,1992:317-18). Therefore, there are now four national confederations with 
which the majority of Dutch trade unions were affiliate: the religiously neutral, socialist FNV, the confessional CNV, the white-collar MHP, and the civil servants' AVC.

Table 2.10: Inflow to and Outflow from Unions in the Netherlands, 1972$1993(\%)$

\begin{tabular}{|c|c|c|c|}
\hline & Inflow & Outflow & Net Growth \\
\hline $1972 / 73$ & 12.4 & 11.0 & 1.4 \\
\hline $1974 / 75$ & 11.9 & 10.7 & 1.2 \\
\hline $1976 / 77$ & 11.4 & 10.0 & 1.4 \\
\hline $1978 / 79$ & 10.2 & 9.7 & 0.6 \\
\hline $1980 / 81$ & 8.3 & 11.1 & -2.8 \\
\hline $1982 / 83$ & 7.3 & 10.0 & -2.7 \\
\hline $1984 / 85$ & 6.1 & 8.8 & -2.8 \\
\hline $1986 / 87$ & 8.3 & 7.7 & 0.5 \\
\hline $1988 / 89$ & 10.9 & 7.2 & 3.7 \\
\hline $1990 / 91$ & 10.9 & 7.6 & 3.3 \\
\hline $1992 / 93$ & 10.3 & 7.8 & 2.5 \\
\hline Source: CBS & & \\
\hline
\end{tabular}

The working days lost due to labor disputes can be considered as a measure of peace in industrial relations or a measure how often workers use the strike as a tool for their various demands. Table 2.11 presents the working days lost in manufacturing industry due to labor disputes per 1000 employees in the European Union for the last decade. The figures for the Netherlands are always less than the average for the union with the exception of 1995. Moreover, the data follows a stable path except in 1990 and 1995. The falling rates denote the weakening of trade union movement and increase in peace in industrial relations for European Union in general and for the Netherlands in particular.

In conclusion, it should be noted that the Dutch labor movement has weakened considerably in recent years if we only consider the membership figures. The membership rate decreased to $29 \%$ in 1995 from its level of $40 \%$ in 1946 . The continuing increase of part-time workers, increasing female participation who are seemingly hard to organize, and the growth of the service sector relative to the manufacturing that is the traditional stronghold of trade unionism made it likely that, at best, union membership would stabilize at present level in the future. 
Table 2.11: Working Days Lost in Manufacturing Industry due to Labor Disputes per 1000 Employees in European Union, 1986-1996

\begin{tabular}{|l|ccccccccccc|}
\hline & 1986 & 1987 & 1988 & 1989 & 1990 & 1991 & 1992 & 1993 & 1994 & 1995 & 1996 \\
\cline { 2 - 14 } & 279 & 185 & 226 & 157 & 179 & 143 & 118 & 113 & 105 & 116 & 80 \\
Austria & 0 & 1 & 0 & 0 & .2 & 0 & 1 & 2 & 0 & 0 & 0 \\
Belgium & n.a. & n.a. & 84 & 164 & 107 & 108 & 206 & 66 & 78 & n.a. & n.a. \\
Dermark & 115 & 114 & 121 & 59 & 102 & 95 & 79 & 159 & 103 & 210 & 102 \\
Finland & 2290 & 145 & 223 & 148 & 101 & 71 & 112 & 28 & 1040 & 29 & 22 \\
France & 73 & 66 & 130 & 111 & 46 & 55 & 45 & 60 & 76 & n.a. & n.a. \\
Germany & 2 & 3 & 4 & 6 & 10 & 13 & 24 & 7 & 15 & n.a. & n.a. \\
Greece & 243 & 348 & 440 & 299 & 392 & 429 & 497 & 206 & 117 & n.a. & n.a. \\
Ireland & 189 & 450 & 237 & 98 & 735 & 59 & 42 & 41 & 31 & 66 & 24 \\
Italy & 350 & 435 & 256 & 282 & 616 & 308 & 279 & 356 & 277 & 91 & 305 \\
Luxerbourg & 0 & 0 & 0 & 0 & 0 & 0 & 0 & 0 & 0 & 0 & 0 \\
Netherlands & 25 & 9 & 3 & 8 & 127 & 40 & 25 & 10 & 8 & 448 & 0 \\
Portugal & 119 & 41 & 39 & 85 & 57 & 41 & 62 & 40 & 43 & n.a. & n.a. \\
Spain & 317 & 843 & 1074 & 711 & 359 & 759 & 497 & 411 & 322 & 285 & 326 \\
Sureden & 3 & 11 & 666 & 41 & 8 & 5 & 0 & 182 & 29 & 13 & 0 \\
UR & 185 & 125 & 280 & 138 & 178 & 43 & 19 & 25 & 12 & 13 & 18 \\
\hline
\end{tabular}

Source: EUROSTAT (1997a).

\subsubsection{Employers' Associations in the Netherlands}

Employers' associations in the Netherlands and all over the world have certain characteristics that contrast with trade unions.

- Employers are individualistic.

- Employers believe in free enterprise and hold generally conservative or traditional liberal political ideas that stress personal freedom and contemplate against membership in organizations.

- Before they join a trade union, workers are comparatively powerless. On the other hand, employers give up their position of authority when they are organized.

- Other employers are often perceived much more as competitors than as allies, thus employers' loyalty to their own associations may be regarded as an alliance of convenience.

- Employer individualism is also shown in the rather opportunistic way most association members are bound to their organization. Each one joins in as long as the organization serves their own interests.

- As in the case of trade unions, there is a tendency in declining membership rates for the employers' associations. 
At the central level in the Netherlands, there are side by side organizations representing employers associations and individual firms which directly or indirectly employ many workers, in particular Verbond van Nederlandse Ondernemingen (Federation of Dutch Industries-VNO) and Nederlands Christeljik Werkgeversverbond (Dutch Christian Employers Union-NCW), and organizations whose members employ few workers or none at all such as agricultural organizations (van Voorden,1984:203). Below the central level there are industry-wide, regional and local associations of employers but individual firms, besides being members of one or more of these organizations, may also belong directly to a central organization. Moreover there are some dual membership in VNO and NCW which take the form of corporate membership in the VNO, directly as an associate member or indirectly through a member association, and personal membership in the NCW for the employer as an individual. Finally, some industry-wide employers associations do not belong to any of the central organization (Voorden,1984).

Some employers organizations participate in collective negotiations on behalf of their members, while others act only in a coordinating and advisory capacity, leaving their affiliated members to negotiate on their own (Barrett,1975). Employers associations are characterized by centralistic procedure more than trade unions. Their leaders usually combine their association positions with the direction of the enterprise (Voorden,1984:226-27). Other developments include the formulation and publication of long-term social and economic policies from an employer perspective, and attempts to seize the initiative in collective bargaining by presenting employer demands at the bargaining table instead of always only reacting to the demands of the unions (Voorden,1984). All these developments have increased the importance of employers associations for their own rank and file. However, their decisions are not binding on members since there are no effective sanctions.

Nowadays, the government's social and economic policies are tending to move from the macropolicy to micropolicy. The stimulating supports that are given preferentially to economically weak sectors of industries and particular regions, and to individual firms, may increase the tensions between members of employers associations and may tend to weaken their cohesiveness. Further tension may be the result of firms growing in size. This makes it difficult to find and maintain a uniform policy. Increase in size of the firms has a negative impact on employers associations in other ways. First, the larger firms prefer to obtain their own expert advice which 
they have been getting from their associations. Second, as firms grow in size they generally spread their risks by diversification. As this process continues, the employers concerned consider themselves less well represented by an association restricted to one particular branch of industry.

\subsection{The Legal Framework of the Dutch Industrial Relations}

In this section the Dutch labor law will be briefly examined for the postwar years. The following subjects are generally seen as the most important part of labor law:

- The rules related to the working environment in the enterprise, such as rules concerning maximum working hours, safety and health. These are rules of public law.

- Individual labor law that focuses on the contract of employment, the rights and duties of the employer and worker, dismissal law and so on.

- Collective labor law that includes trade union law, collective bargaining, strikes and institutional participation.

- Social security law.

From the four subjects the collective labor law will be discussed in more detail.

With the latest amendment in 1907, the Civil Code included many provisions concerning the contract of employment that are still in effect for the contractual relations between employer and worker. The Civil Code defined the contract of employment as a contract by which one party promises to supply his labor to another party during a certain period of time; in exchange for wages to be paid, and in subordination to, that other party (Ven, 1986). The word "in subordination" stands for the authority of employer to unilaterally issue binding rules concerning the way in which the work has to be done or the organization of the enterprise.

In order to shape active labor market policy, the objectives and tasks of Public Employment Service (PES) are defined in the Employment Service Act (ESA) of 1990. The main objective of the PES is to promote an efficient and balance in the supply of and demand for workers on the labor market. In order to accomplish this objective, the following tasks should be performed (Koning, et.al.,1996): 
- The registration of job-seekers and vacancies notified by employers.

- The collection and provision of labor market information.

- The provision of information or advice, such as professional guidance.

- The placement of job-seekers.

- The provision of vocational training and encouragement of other organisations' activities in this field.

- Contributing to the development of policy regarding the apprenticeship system.

The reforms of 1990 had three themes: tripartition, decentralization and demonopolisation. Moreover, PES has given a coordinating and stimulating role related with the labor market policy. PES was also held responsible for the implementation of active labor market measures. In this framework, a special importance was assigned to regional labor markets via municipalities. The amendment of 1996 on the ESA includes the following changes (Koning, et.al.,1996:101):

- The new act explicitly states that the PES has to concentrate on the hard-to-place unemployed.

- The cooperation between the PES, the municipal social services and the industrial social insurance boards is to be increasingly stimulated.

- Changes in the administrative and financial structure.

- A reduction of the number of regions.

The PES has a limited ability to affect the excess supply of labor because it has weak tools to stimulate employment. Therefore, the short-term task of PES is to fill the existing vacancies and provides equal opportunities for different groups of unemployed. According to Koning, et.al (1995), the most important problem in the labor market is the shortage of jobs and PES is not equipped with to solve this problem. Moreover, it is observed that PES is not successful to provide equal opportunities for different groups and unemployment remains unequally distributed over the various groups (Koning, et.al.,1995:36). If PES solves the problem of redistribution of chances through appropriate policies, the long-term unemployment will decrease and consequently the total unemployment will be reduced. ${ }^{14}$

\footnotetext{
14 When analyzing the duration structure of unemployment in the previous section, it is observed that there is a significant long-term unemployment problem in the Netherlands.
} 
The temporary employment business, that is the temporary hire of a worker for monetary reward by a temporary work agency to an employer is a fairly new phenomenon in the Netherlands (Blanpain and Engels,1993). Temporary work agencies existed before World War II, yet their number was negligible. However, this situation changed in the 1950s when the number of temporary work agencies began to increase at a rapid rate (Blanpain and Engels,1993). This development had some drawbacks, some temporary agencies, especially those specialized in hiring out bluecollar workers to manufacturing industries, turned out to be rather low, taxes and social security premiums were not paid, the regulations concerning maximum working hours were not observed, and they paid extra high wage to their temporary workers (Bakels and Opheikens, 1982). Starting in 1965, the government took action and several acts were promulgated to deal with above mentioned abuses.

According to the Law of 1990 , temporary work is defined as the hiring out of workers to another person in return for payment in order to perform under supervision of that other person normal work in his enterprise without a contract of employment existing between those workers and the other person (Rood, 1995). Moreover, only licensed temporary work agencies are allowed to hire workers and the license is obtained from a tripartite institution when certain conditions have been fulfilled such as (Rood, 1995):

- The temporary work agency must not in any way hamper the temporary worker's entering the service of the user.

- The hiring out of temporary workers to work in a strike bound firm is prohibited.

- The hiring out is only possible for work of a temporary nature.

Hiring employees is not permitted in the building sector in which temporary work agencies were forbidden. The maximum duration of temporary work with the same hiring employer has been extended to one year in 1995, before that time it was six months.

The hours of work were regulated by a set of statutory provisions and they can be summarized as follows (Ven, 1986):

- a maximum working day of 8.5 hours and a maximum working week of 48 hours,

- no work is allowed on Saturday afternoons and Sundays,

- no work is allowed during the night,

- minimum successive 36 resting hours per 7 days. 
However, Working Time Act is amended in 1996. This new act has a tendency towards more flexible arrangements and deregulation. Moreover, the new law departs from the so-called standard working time that may be changed by collective agreements within certain limits (Rood, 1995). The main provisions are as follows (Koning, et.al., 1996:81):

- a maximum working day of 9 hours and a maximum working week of 45 hours,

- average working time of 40 hours per week,

- average working time of 520 hours per 13 weeks,

- minimum resting time of 11 hours per day,

- minimum successive 36 resting hours per 7 days or 60 per 9 days,

- maximum 8 hours of night work per 24 hours,

- minimum leave of 4 weeks per year,

- minimum 5.5 hours of work requiring a break.

After reviewing the individual labor law, it is possible to continue with the collective labor law, i.e. trade unions, collective bargaining, and industrial disputes. Freedom of association is guaranteed by the Constitution in which permission of government is not required in order to found an association (Rood, 1995).

According to Collective Agreement Act, a collective agreement is an agreement by which mainly working conditions are regulated that must be observed in the case of contracts of employment (Rood, 1995). As specified in the Act of 1937, the Minister of Social Affairs and Employment is authorized to declare the provisions of a collective agreement binding on an entire industry if a significant majority of the employers and workers in the industry are already covered by the agreement and extension is only possible at the request of one or more of parties to the collective agreement (Roo and Jagtenberg, 1994).

After the collapse of the central wage policy of 1960 s, the level of collective bargaining shifted to industry level and this may explain the low union membership rates. The Wage Determination Act of 1970 incorporated the principle of free collective bargaining in the sense that collective agreements no longer required previous approval by an authority formed for that purpose. But although the government had lost its former strong position, the Act granted it some power in the form of the Minister of Social Affairs and Employment having the power to issue a wage regulation to freeze wages for a maximum period of six months (Rood, 1995). 
The issue of strikes in the Netherlands is not covered by any specific legislation. In case a quick decision is urgently needed, the president of a District Court can give a summary decision that is subject to appeal and appeal in cassation, but very often the decision of the president acts as a final judgment (Rood, 1995). In the case called as Panhonlibco case of 1960, Supreme Court decided that workers engaged in a strike were, in general, guilty of a breach of contract, and, therefore, the union which organized the strike was liable in tort for inducing a breach of contract (Rood, 1995). However, the Supreme Court did not specify under what circumstances such lawful stoppage of work would be justified (Roo and Jagtenberg, 1994). According to Windmuller (1969) the Supreme Court's legal doctrine had no parallel among industrialized democracies. In 1969, a bill that aimed to reverse the decision of Supreme Court was introduced and the union acted unlawfully in only five cases according to bill (Rood, 1995). These causes are:

- if the strike is contrary to statute law,

- if the strike is contrary to a collective agreement which the union has entered into,

- if the strike is contrary to the existing norms in relations between organizations of employers and workers,

- if there exists a manifest disproportion between the ends and the consequences of the strike,

- if the strike is unreasonable towards the employer.

The bill still being before Parliament was withdrawn in 1980. However, it had already done its work because since its introduction the courts interpreted the Panhonlibco decision in the light of the contents of the bill (Rood,1995). In 1980, the Netherlands ratified the European Social Charter of which Article 6 stated that the member states of the Council of Europe should recognize the right of workers and employers to collective action in cases of interest, including the right to strike (Rood,1995). There is also no special regulation for lock-outs like strikes, and number of strikes in the Netherlands are very low because of the social consensus attained.

The last point for the summary of legal framework of the Dutch industrial relations is related with the minimum wages. The Minimum Wage Act of 1968 lays down a compulsory minimum wage for all workers, male and female, between the ages of 23 and 65 . By a decree issued by the Minister of Social Affairs and Employment in 1974, a minimum wage for workers in the 15-22 age group was also 
fixed. The minimum wage was regularly adjusted to meet the rising wage level by the Minister of Social Affairs and Employment who in this way provides a basis for collective bargaining (Blanpain and Engels,1993). The minimum wages and benefits linked to minimum wages are indexed on the basis of average trend in the collectively agreed wages in the public and private sectors (Koning, et.al,1996:84). However, the government may decide not to apply the indexing of minimum wages and benefits during economically hard times. The indexing and the possibility not to apply the indexing are regulated in a separate act in 1992. In 1993,1994, and 1995, indexing did not take place on the basis of this act.

In conclusion, it can be claimed that the impact of central government and centrally organized tripartite institutions in the legal wage determination process declined gradually through the years and the approach in the legal framework became more individualistic.

\subsection{Revisiting Dutch Labor Market}

It is possible to claim that Dutch central wage policy was successful in 1950 s and early 1960s when we look at the period after the war. One of the most important factor to reach such a judgement is the extreme consensus amongst the agents to rehabilitate the economy after the war. Once the economy is reconstructed, the centrally guided wage policy was in a way to transition. Naturally, the transition did not take place from one extreme-guided wage policy- to another-free wage negotiations. In the late 1960 s, we observe the first attempts towards a mixture of centralization and decentralization of wage determination. During the following years, the degree of centralization decreased but never came to an end. Central bodies kept their parental position in some extent. Therefore, as Veen (1997:37) stated "in Dutch wage setting two elements continuously show up: first, wage bargaining and second, the centralization-decentralization debate."

One of the most distinguishing characteristics of Dutch labor market is the increasing participation rates. The factor behind this trend is the continuously increasing and accelerating rate of female participation especially in 1980s. Another significant point is the increasing share of part-time employment from the early 1970s. Unemployment rates reached its peak in the early 1980s. However, there is a general trend of decrease in the last decade and the rate is well below the average of 
European Union and the third lowest in union. There are various sources of the existence of unemployment in the Netherlands but the most important cause is the long-term characteristic of it. Moreover, there are also some difficulties to create new vacancies.

When the Dutch manufacturing industry is analyzed because of the special importance attached in this study, it is observed that both the employment share and number of workers in the manufacturing industry shows a continual decrease. On the other hand, there are stable wage differentials amongst the sectors of manufacturing industry. Another somewhat stable trend is the rise in real wages.

In the postwar period, we saw a reflection of worldwide trend in Dutch labor market, decreasing union membership rates and nowadays it stabilizes around $30 \%$. The strongest confederation FNV's share is approximately $60 \%$. Moreover, it is possible to claim that the industrial relations are peaceful in the Netherlands in terms of the working days lost during labor disputes. As in the case of workers, employers have also a declining tendency to organize.

In 1990s, the legal framework of Dutch industrial relations has undergone important changes. The Employment Service Act of 1990 and the amendment in Working Time Act of 1996 have been counted as the milestones in this process of change. The influence of government and central organizations in the labor market declined gradually in the legal wage determination process, the powers are shifted to local governments and industry level organizations.

In sum, Dutch labor market can be treated as a good example with its various characteristics such as incredible consensus amongst the agents, part-time work tradition, and legal framework summarized above. 


\section{APPENDIX 2A: THE CHRONOLOGY OF THE DUTCH TRADE UNION MOVEMENT}

1861 First trade union established in the printing trades.

1866 First national trade union, the General Netherlands Union of Typographers, founded.

1871 Formation of the Dutch section of the Socialist International, the Netherlands Federation of Laborers, and moderate (liberal) General Netherland Federation of Laborers.

1872 Abolition of prohibition against coalition contrary to public order.

1893 National Labor Secretariat established.

1903 Railway strikes.

1906 Creation of the Netherlands Federation of Trade Unions and the Federation of Roman Catholic People's and Workers' Unions.

1909 Creation of the National Federation of Christian Trade Unions in the Netherlands and the Roman Catholic Trade Office.

1910-20 Change from craft to industrial union system.

1914-18 World War I.

1927 Law on Collective Agreements (Wet op de collectie arbeidsovereenkomst).

Employers forced to apply industry agreements to both organized and unorganized workers.

1937 Further legislation on collective agreements compels unorganized employers to obey the labor terms agreed upon for the industry through collective bargaining.

1940-45 World War II.

Holland under German occupation.

1945 Foundation of Labor established. .

1950 Law on Works Councils, revised in 1971 and 1979. Creation of Social Economic Council.

1970 Law on Wage Forming (Wet op de Loonvorming) gives employers and trade unions primary responsibility for setting wages, but spells out a distinct role for the government.

1974 Federation of Trade Unions for Staff and Managerial Personnel established. 
1976-82 Gradual merger of the two largest federations into the Netherlands confederation of Trade Unions (FNV).

1990 General Trade Union Federation (AVC) established.

1995 Social Affairs Minister presented a policy document on increasing flexibility in the labor market in the phase of increasing unemployment.

Source: Campbell (1992:572-73). 
Table A1: ISI Classification

\begin{tabular}{||rl||}
\hline Codc & \\
311 & Food manufacturing \\
312 & Manufacture of food products not elsewhere classified \\
313 & Beverage industries \\
314 & Tobacco Manufactures \\
321 & Manufacture of Textiles \\
322 & Manufacture of wearing apparcl, except footwear \\
323 & Manufacture of leather and products of leather, leather substitutes and fur \\
324 & Manufacture of footwear,except vulcanized or moulded rubber of plastic footwear \\
331 & Manufacture of wood and wood cork products, except furniture \\
332 & Manufacture of furniture and fixtures, except primarily of metal \\
341 & Manufacture of paper and paper products \\
342 & Printing, publishing and allied industries \\
351 & Manufacture of industrial chemicals \\
352 & Manufacture of other chemical products \\
353 & Petroleum refineries \\
354 & Manufacturc of miscellaneous products of petroleum and coal \\
355 & Manufacture of rubber products \\
356 & Manufacture of plastic products not elsewhere classified \\
361 & Manufacture of pottery,clina and earthenware \\
362 & Manufacture of glass and glass products \\
369 & Manufacture of other non-metallic mineral products \\
371 & iron and steel basic industries \\
372 & Non-ferrous metal basic industries \\
381 & Manufacture of fabricated metal products, except machinery and equipment \\
382 & Manufacture of machinery, except electrical \\
383 & Manufacture of electrical machinery, apparatus, appliances and supplies \\
384 & Manufacture of transport equipment \\
385 & Manufacture of professional and scientific and measuring and controlling equipment optical goods \\
390 & Other manufacturing industries \\
\hline
\end{tabular}

Source: SIS (1990) 
APPENDIX 2C: ILO AND OECD DATA ON THE DUTCH LABOR MARKET 


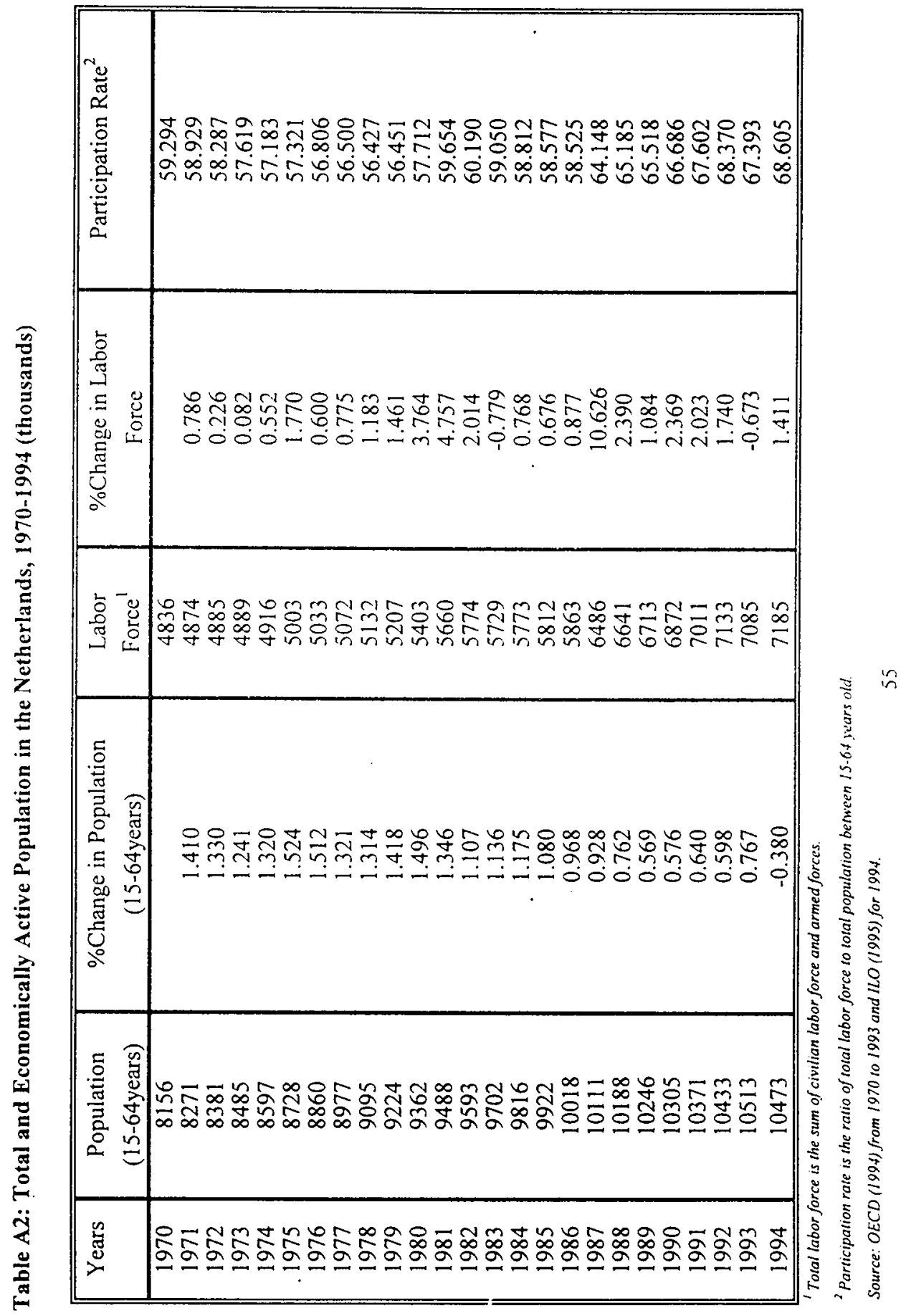




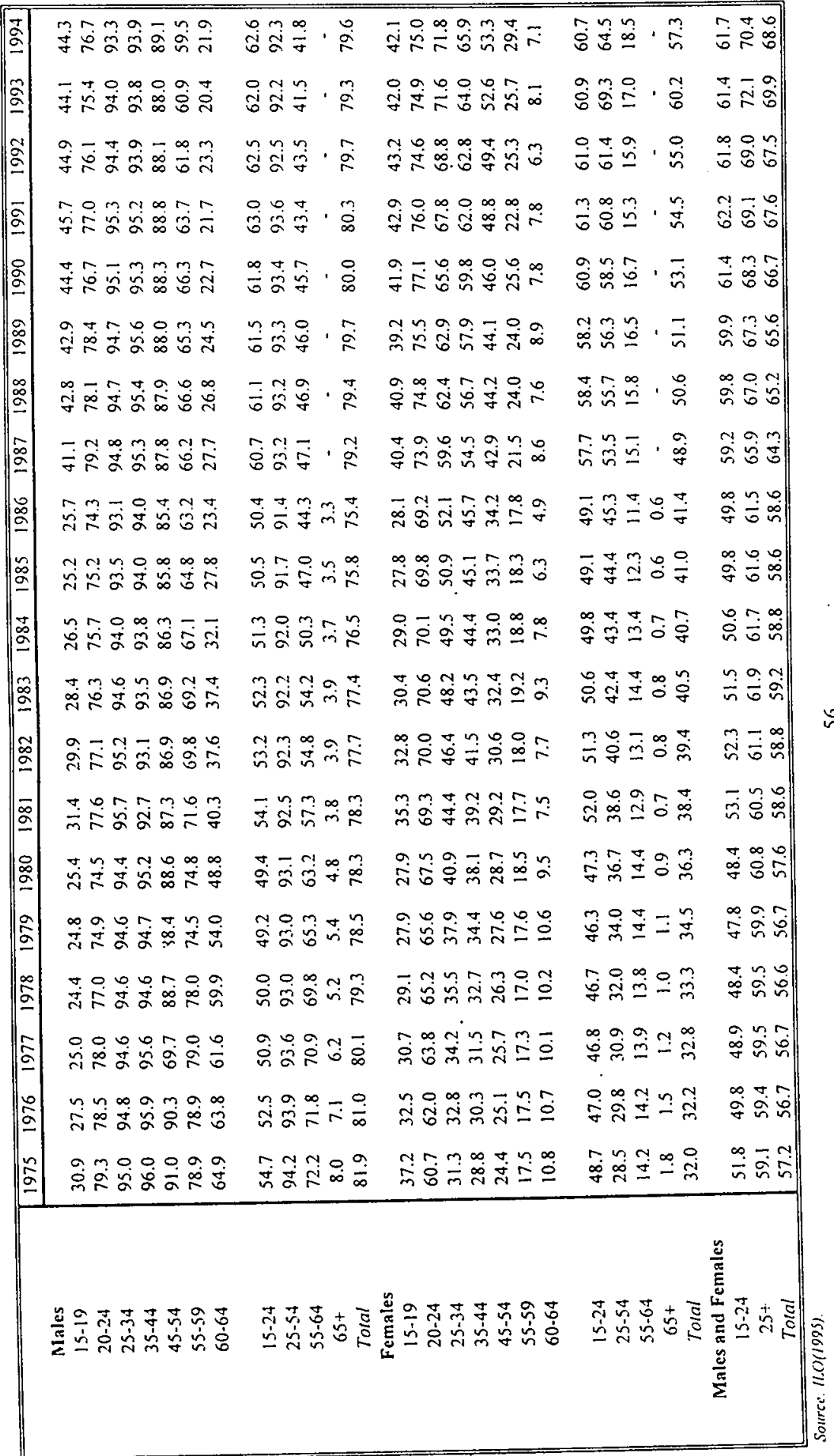


Figure A1: Participation Rates by Sex in the Netherlands, 1975-1994

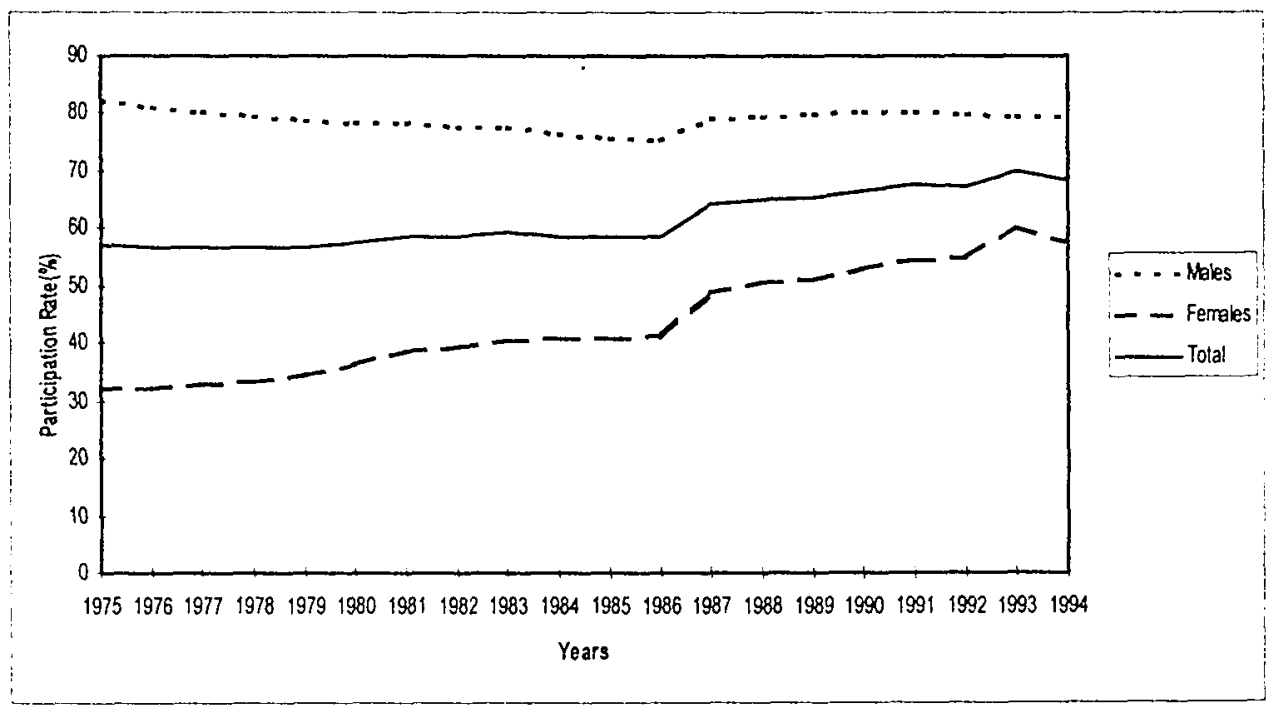

Source: Table A3.

Figure A2: Share of Part-Time Employment in the Netherlands, 1975-1991

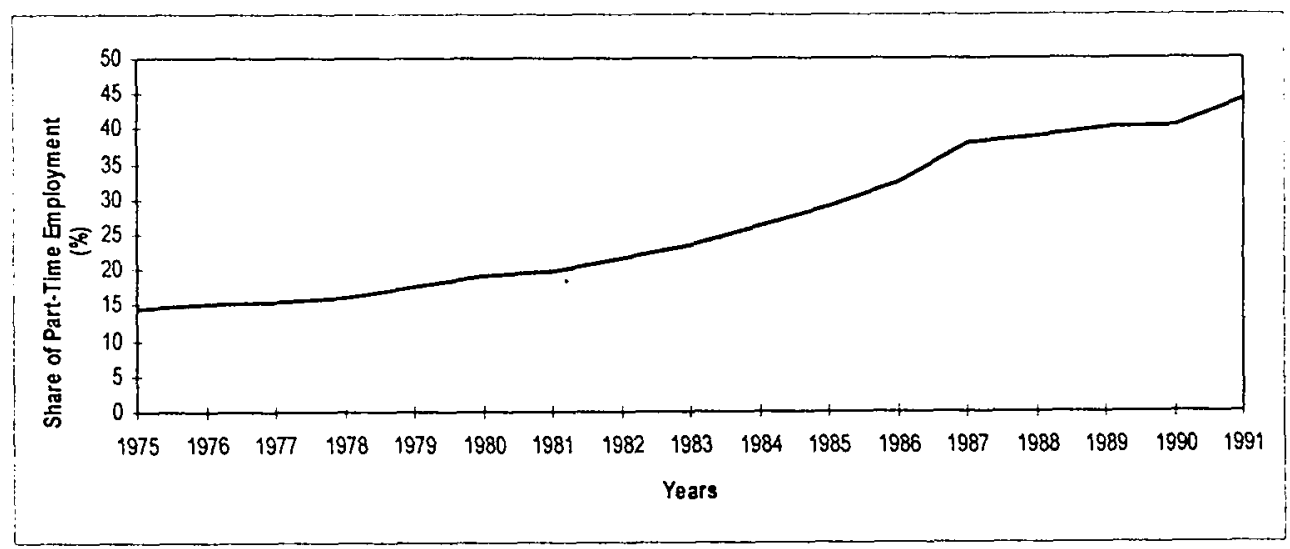

Source: OECD (1994a). 


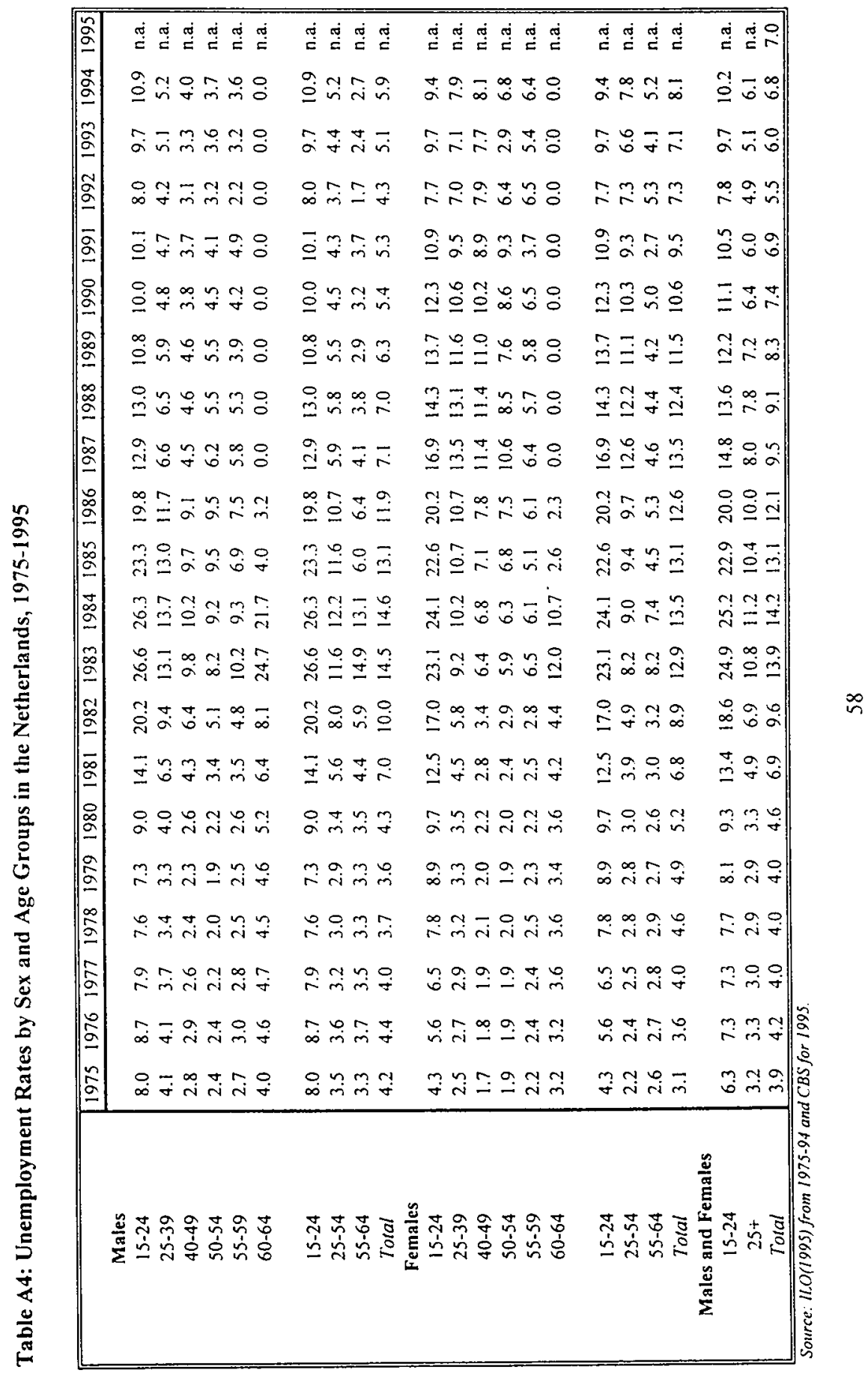


Figure A3: Unemployment Rates by Sex in the Netherlands, 1975-1994

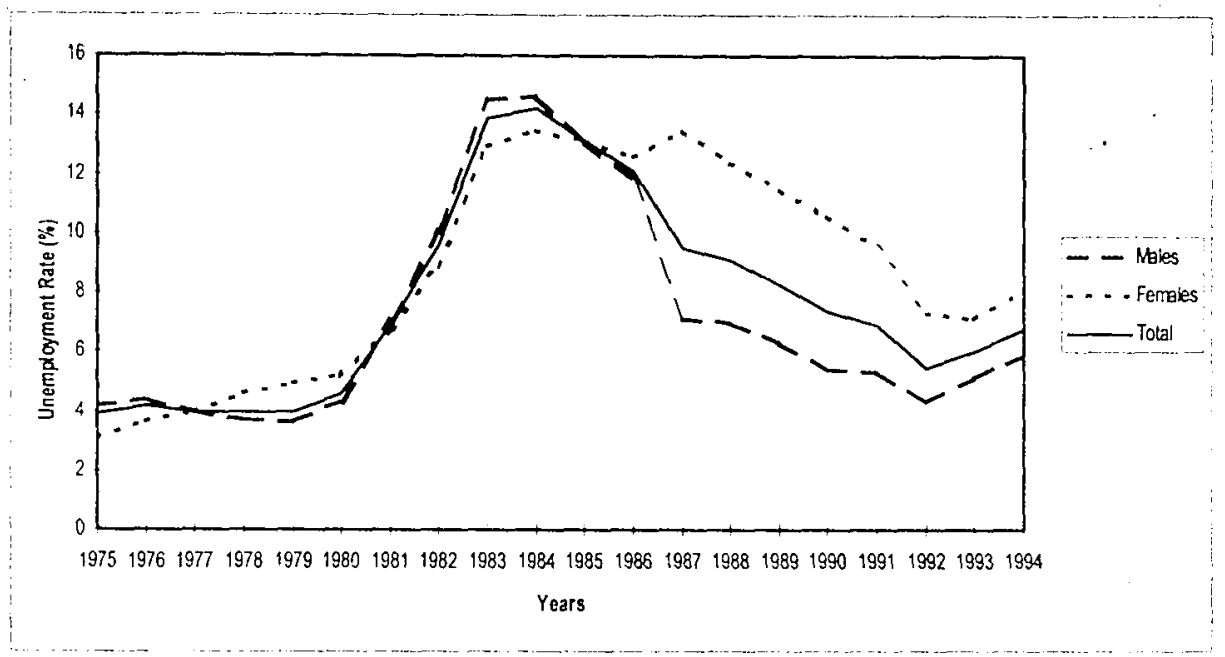

Source: Tabled

Figure A4:Duration Structure of Unemployment in the Netherlands, 1983-1989

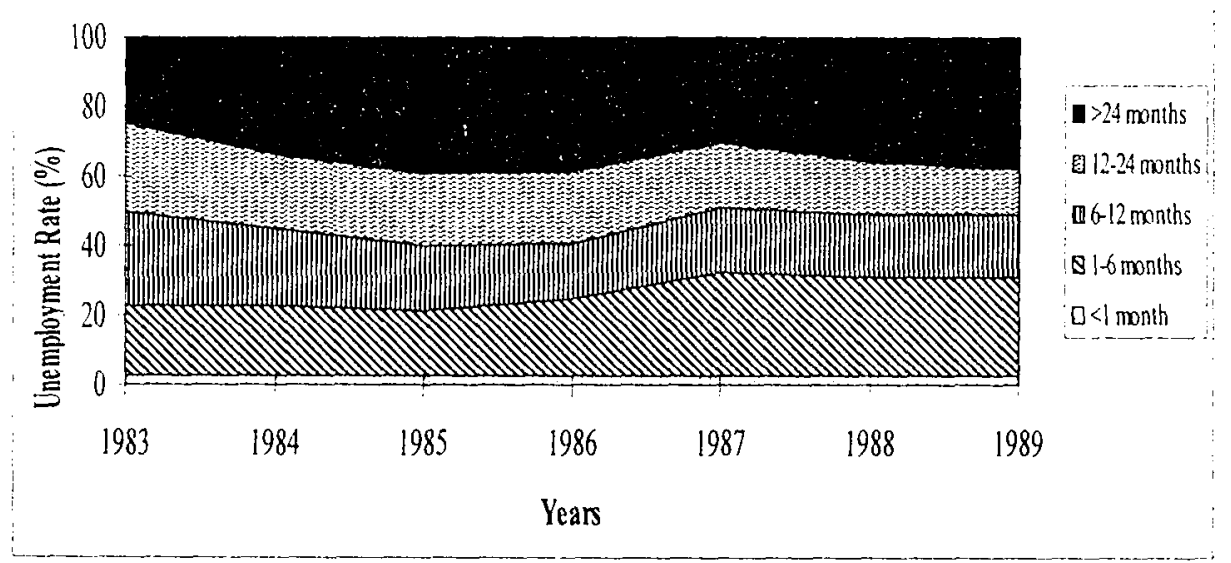

Source: OECD (1994a). 


\section{TURKISH LABOR MARKET: THE VICTIMS OF INSTABILITY}

\subsection{The History of Turkish Labor Market (1946-1995)}

The history of Turkish labor market can be analyzed under four sub-periods that were shaped by political and economic transformations.

\subsubsection{Articulation with the World Economy, 1946-53}

1946 is a milestone for both political and economic history of Turkish Republic. Politically, it is the date of transition from one-party to multi-party regime. Economically, after 16 years of closed economy with high protectionism and inwardlooking strategies, more liberal policies were implemented. In this period, as a result of outward-looking strategies, growth and development was based on foreign trade and priority was given to agriculture, mining, and construction sectors with increasing infrastructural investments. However, chronic balance of payments deficits caused the economy to be dependent on foreign resources and this would be one of the predominant characteristics of Turkish economy in the following periods. The main economic indicators of this period show rapid economic growth. Between 1946-53 the annual average of GNP growth is $11 \%$. As a response to this rapid economic growth, the real income of all social classes increased tremendously. The workers whose absolute living standards were really low during the war years reached a real income level quite above its prewar level. ${ }^{15}$ Unfortunately, this tendency cannot be observed in terms of income distribution. The share of wage earners from GNP, with the exception of agricultural workers, decreased from $19.5 \%$ to $16.1 \%$.

\subsubsection{Bottleneck and Adaptation, 1954-61}

This period begins with a major bottleneck because of limited foreign resources and falling export demand. As a reaction to this situation, liberal foreign trade policies ended and some import restrictions were applied. These years witnessed

is According to an estimate real wages rose by $73.3 \%$ in the period $1944-1953$ (Boratav, 1989:82). 
an irregular urbanization. The ratio of urban population which was $18 \%$ in 1945 reached $25 \%$ in 1960 . The main reasons behind this rapid urbanization were commercialization of agricultural products and mechanization in agriculture. The mechanization of agriculture, in turn, caused a labor surplus in rural areas. In other words, urbanization was not the result of new employment opportunities in urban areas. Moreover, the share of wage-earners in urban population continuously decreased throughout the period but as a result of a chaotic urbanization and migration from rural areas the share of people working in flexible jobs increased (Boratav, 1989:86). Labor force participation rate increased by 7\% between 1955 and 1960 meaning a $1.4 \%$ annual increase. This is, however, less than the increase in population growth. The sectoral distribution of labor force is given in Table 3.1. The most important point in this table is the high percentage change in service sector. The newcomers from rural arcas are mostly concentrated in service sector. Although the share of agricultural employment decreased, it still constituted $78 \%$ of total employment. The small change in the share of industry signifies that the employment opportunities in industry were rather limited. After 1956, the increase in wages is far less than the increase in prices. Therefore, real wages deteriorated especially for the period 1958-1960.

Table 3.1: Sectoral Distribution of Labor in Turkey

$1955-1960(\%)$

\begin{tabular}{|c|c|c|c|c|c|}
\hline \multirow[t]{2}{*}{ Sxctors } & \multicolumn{2}{|c|}{1955} & \multicolumn{2}{|c|}{1560} & $.955-1960$ \\
\hline & Nuner of itimers & Ferorentoge Share & Wriber of horkers & Faronivige Sinare & Eeraetitage Chatge \\
\hline Agrialture & 9446 & 80.77 & 9737 & 77.68 & 3.03 \\
\hline ivining & 63 & 0.54 & 77 & 0.61 & 22.22 \\
\hline Indistry & 720 & 6.21 & 885 & 7.06 & 21.90 \\
\hline Bhergy & 16 & 0.14 & 15 & 0.12 & -6.25 \\
\hline Services & 1494 & 12.35 & 1820 & 14.52 & $26.0 \alpha_{i}$ \\
\hline Total & 11695 & 100.00 & 12534 & 100.00 & 7.17 \\
\hline
\end{tabular}

Source: $O E C D(1970)$

\subsubsection{Planned Development, 1962-79}

The main characteristics of this period are the experiences of a planned economy and the implementation of import substitution policies. The adaptation of the planned economy is in fact a reaction to the bottleneck experienced in the second half of 1950 s. But this period ends with a more serious crisis at the end of the 1970 s. 
Trade and industrialization policies in this period have been based on import substituting industrialization under heavy protection. The heavy commitment of Turkish planners to rapid industrialization through import substitution after 1960 has meant that employment issues were totally neglected. Although employment was frequently argued to be one of the main development targets in five-year plans, this was under the understanding that it would be relegated to the background should it in any way come into conflict with rapid industrialization and technical change targets. Certain aspects of import substitution policies have been mainly held responsible for the slow pace of employment creation. While the price of the abundant factor, labor, was kept artificially high, the scarce factor, capital, was made available to the manufacturing sector at more favorable terms through a series of policies ranging from the maintenance of overvalued exchange rates and low interest rates to a variety of tax, credit, and other fiscal and monetary incentives. A major force behind wages rising above their market-clearing levels during this period was the emergence of a social and political environment which was on the whole conducive to the realization of the rising demands of organized labor. Even though the right for free collective bargaining was granted to the unions in 1963, trade unions emerged as a dominant force in wage determination for much of the period until the military coup d'etat in 1980. There was also increased militancy as reflected by the number of workers participating in strikes in addition to the rapid increase in the number of trade unions and their members. Most collective bargaining agreements included terms not only for protecting wage levels against future inflation but also for payment of generous bonuses and fringe benefits (Şenses, 1990:8). Moreover, trade union members could draw severance pay when fired or upon retirement that on top of its implications on job security was another factor instrumental in increasing labor costs. Another factor contributing to the rising trend in wages during this period was the high rates of profitability attained especially in highly-protected sectors. The government also played a significant role in this process of rising real wages through wage increases in state economic enterprises. It would be an important mistake, however, to view this process as harmonious as the state interfered into the free collective bargaining process and reversed the rising trend in real wages on two occasions even during this what turned out to be the most liberal phase of the evolution of Turkish labor rights. The military intervention during 1971-74 and the declaration of marshal law in a large number of provinces during a period of growing economic crisis were accompanied 
by a fall in real wages. Despite these interruptions which implied a fall in real wages on average by $3.9 \%$ during 1970-72 and by $16.3 \%$ during $1978-79$, real wages increased on average by 5.3\% during 1963-70 and by 4.3\% during 1973-77 (Işlkh, 1990:324). On the other hand, the policy of keeping interest rates low in the face of accelerating inflation led to the emergence of negative rates especially in the late 1970s. It is likely that keeping the nominal exchange rate constant over long periods led to overvaluation of Turkish Lira, and this became chronic during the same period with the appreciation of Turkish Lira against the dollar in real terms during the 197380 period. The policies vis-à-vis factor prices were instrumental in increasing the wage-rental ratio and were as elsewhere among factors encouraging the utilization of relatively more capital-intensive methods of production. Another significant factor was the extension the process of import substitution into intermediate and capital goods with relatively higher capital intensity. Finally, the increasing role of the state in this stage of import substitution also contributed to this process as state economic enterprises were all characterized by high capital intensity. All these factors imply that markets for labor, capital, and manufactured goods were characterized by heavy distortion leading to growing capital intensity in the manufacturing sector with incremental capital-output ratios rising from 1.6 in $1963-67$ to 2.4 in $1968-72$ and to 4.7 in 1873-77 (World Bank, 1982:1-2). As a reflection of these trends the rate of growth of manufacturing employment decreased from $4.6 \%$ annually in 1967-73 to $1.7 \%$ annually in 1973-79. In the face of low levels of employment creation in manufacturing, there was heavy recourse to several areas to cope with the growing pressures coming from the supply side of labor market. First, there was an increasing demand for Turkish labor in Western Europe during 1963-73 which managed to create roughly the same amount of employment as the domestic manufacturing industry during the same period. Second, there was an excessive hiring of labor by state economic enterprises. Third, small scale enterprises accounted for $15 \%$ of employment creation in the manufacturing sector during 1963-80. The relatively higher share of these enterprises in employment than in production in this sector may be attributed to the fact that the utilization of both labor and capital was more in line with their scarcity value than in larger enterprises. Finally, the share of service sector in employment increased from $14.5 \%$ to $25 \%$ during the $1960-80$ period. There are two factors accounting for the low levels of employment creation by the manufacturing sector. First, there was a rapid increase in productivity with the rate of 
growth in average labor productivity in the private and public sectors reaching on average $9 \%$ and $7 \%$ respectively during 1965-75. Second, the rate of growth of employment creation was closely associated with growth in manufacturing production. The fall in the annual average rate of growth of manufacturing employment from $4.6 \%$ to $1.7 \%$ from $1963-73$ to $1973-79$ was accompanied by a fall in the growth of manufacturing value added from $9.8 \%$ to $4.6 \%$ during the same period.

\subsubsection{Stabilization, Structural Adjustment, and Export-Orientation, 1980-Present,}

Economic policies applied under the stabilization and structural adjustment program were one of the most significant transformations in Turkish economic history and were opposed to earlier policies with respect to their implications for the labor market. Although there was originally no direct labor market policy in the stabilization and structural adjustment program, some specific policies like exchange rate adjustment, trade liberalization, wage restraint, a more restrictive labor environment, interest rate reform, and the reduction in the role of state in economic life in general, and in manufacturing in particular had enormous impacts on labor market. The primary emphasis was on policy realignment in both domestic factor markets and the foreign trade regime. The fifth five-year plan of 1985-89 has argued that through such policy reforms it would be possible to employ relatively more laborintensive technologies and specialize in activities in line with existing factor endowments. Moreover, the sixth five-year plan of 1990-1994 has stated that the structure of production is directed in accordance with the employment creation target while taking into account productivity and efficiency considerations as well. The implementation of the stabilization and structural adjustment program took place against the background of a highly restrictive environment for organized labor. This was a reflection of a growing reaction on the part of employers' association to rising real wages and growing trade union militancy at the end of the 1970s. This legitimized the political argument for restraining the power of trade unions. In the economic view, the creation of an exportable surplus and controlling inflation required domestic demand restraint for which wage restraint was used as a key factor. Wage restraint was also regarded as an important tool for attaining international 
competitiveness under an export-oriented strategy as wages were regarded as an important cost item. Reactivating the excess capacity for export markets as well as success in wage restraint required peaceful industrial relations which were expected to increase Turkey's relative attractiveness for foreign investors. The military coup d'etat in September 1980, was eight months after the introduction of stabilization and structural adjustment program, banned all trade union activity, suspended free collective bargaining and strikes, and started a period of new labor law aiming at curbing trade union power in wage determination. The available evidence shows that there was a quite big fall in the real wages during 1981-86 against significant rise in productivity. Then the real wages increased until gulf crisis and begin to fall thereafter. Therefore, the real wages were highly volatile in this period. This trend in real wages was strengthened by other policies such as the restriction on the scope of maximum payments that can be made under the severance payments scheme, reduction in pensions as a share of basic wages, reduction on the number of days designated as public holidays, the loss of payments at overtime rates on those days, and the reduction in the maximum number for bonus payments that could be made each year. Although employment creation in the post-1980 period under exportoriented policies seems to have performed better than in the earlier period of import substitution, it can be said that relative performance in this respect was not as sharp as the advocates of export-oriented policies claimed. While the rate of growth of employment in the 1980s under export-orientation was almost equal to the rate of employment creation in other developing countries during the 1960 s and the $1970 \mathrm{~s}$, it was slightly over the rate attained in Turkey during 1963-1980 under import substitution. An important characteristic of the pattern of employment under exportoriented policies was the fact that there was overall a very weak response to the new industrial trade policies with none of the alleged favorable employment effects of export-orientation so far making a major impact. In fact, underutilized capacity was reactivated rather than creating new capacities. It seems that factors on the supply side of the labor market will last to shape the market in the future. The sheer size of new entrants into the labor force with increased concentration in urban areas indicates that employment creation will fall short of these pressures from the supply side. 


\subsection{Main Characteristics of the Turkish Labor Market}

It is possible to argue that the labor market is the area where dissimilarity between Turkey and other OECD members is by far the greatest, a degree of similarity with Portugal and Spain notwithstanding. The current and projected rates of growth of population and labor force, the level of educational attainment and skill composition of labor force, the share of agriculture in total employment, the low productivity of labor in agriculture as well as in the informal sector in urban areas, the small share of wage-earners in total labor force, and massive shifts in the sectoral distribution of labor force through rural-urban migration are among the major structural characteristics which place Turkey within the category of semiindustrialized countries.

It is possible to model the Turkish labor market on the basis of a three-tier segmented model composed of agriculture, urban informal, and the formal sector. The productivity differential between non-agriculture and agriculture is far bigger than cross-country norms reflecting in large part the low absolute level of agricultural productivity. As a reflection of this situation, structural change in labor force towards non-agricultural activities has lagged significantly behind that of gross output. Furthermore, the low level of female participation rates in urban areas gives weight to the discouraged worker hypothesis and point to the importance of cultural and gender issues in examining labor market. Likewise, the employment of child labor in both agriculture and the informal sector, differences in the regional distribution of income, and the existence of seasonal migration in agriculture are among factors to be taken into account in order to understand the functioning of the Turkish labor market. The fact that a part of urban labor force in some form retains its economic as well as social links with agriculture should also be considered. Similarly, massive labor emigration to Western Europe in the 1960s and early 1970s, apart from its role in alleviating labor market pressures, has established similar links between emigrant workers and the domestic labor force through remittances.

In conclusion, the main characteristics of Turkish labor market can be summarized and listed as follows:

- a high rate of population growth, 
- a large proportion of population live in rural areas and work in agriculture with low productivity,

- a serious employment problem with the unpaid family workers having a special weight in the economy,

- a high rate of migration from rural to urban areas while job-creating capacities of urban areas and industry are limited. As a result, there is a serious problem of unemployment problem in urban areas,

- the labor market is segmented in several ways as explained previously,

- labor is heterogeneous with large wage differentials,

- the economy and the labor market are somewhat insensitive to trade cycles,

- the inadequacy of new job creation is more important for the Turkish labor market than the destruction of jobs.

\subsubsection{Labor Force and Participation}

Table 3.2 below gives the total and economically active population over 12 years old in Turkey for the period 1970-1995. As can be seen from this table, population over 12 years old generally increases with some significant exceptions such as in 1976, 1981, 1986, 1989, 1991, and 1994. The highest figure is observed in 1993. Between 1992 and 1993 population over 12 years old increased more than $6 \%$.

As compared with the labor force, change in population is less volatile or more stable. Higher increases, even a decrease in 1981, can be seen from the figures of labor force. Changu in labor force is never more than $4.5 \%$ in a year.

In terms of the participation rates, we observe a continuous decline. From 1970 to 1995 , this tendency continues and participation rate decreases from $64.5 \%$ to nearly 50\%. This is the most significant conclusion drawn from Table 3.2.

The participation rates by sex and age groups are presented in Figure 3.1 and Table 3.3. Participation rates for both males and females follow a stable path in the period of analysis. For males, it gradually declines from $76.5 \%$ to $72 \%$ but for females it is not possible to observe such a decline. However, some drastic changes can be seen for females between 1990 and 1991. For the whole population, there is a considerable decrease in the participation rate from $55.6 \%$ to $50.4 \%$. 


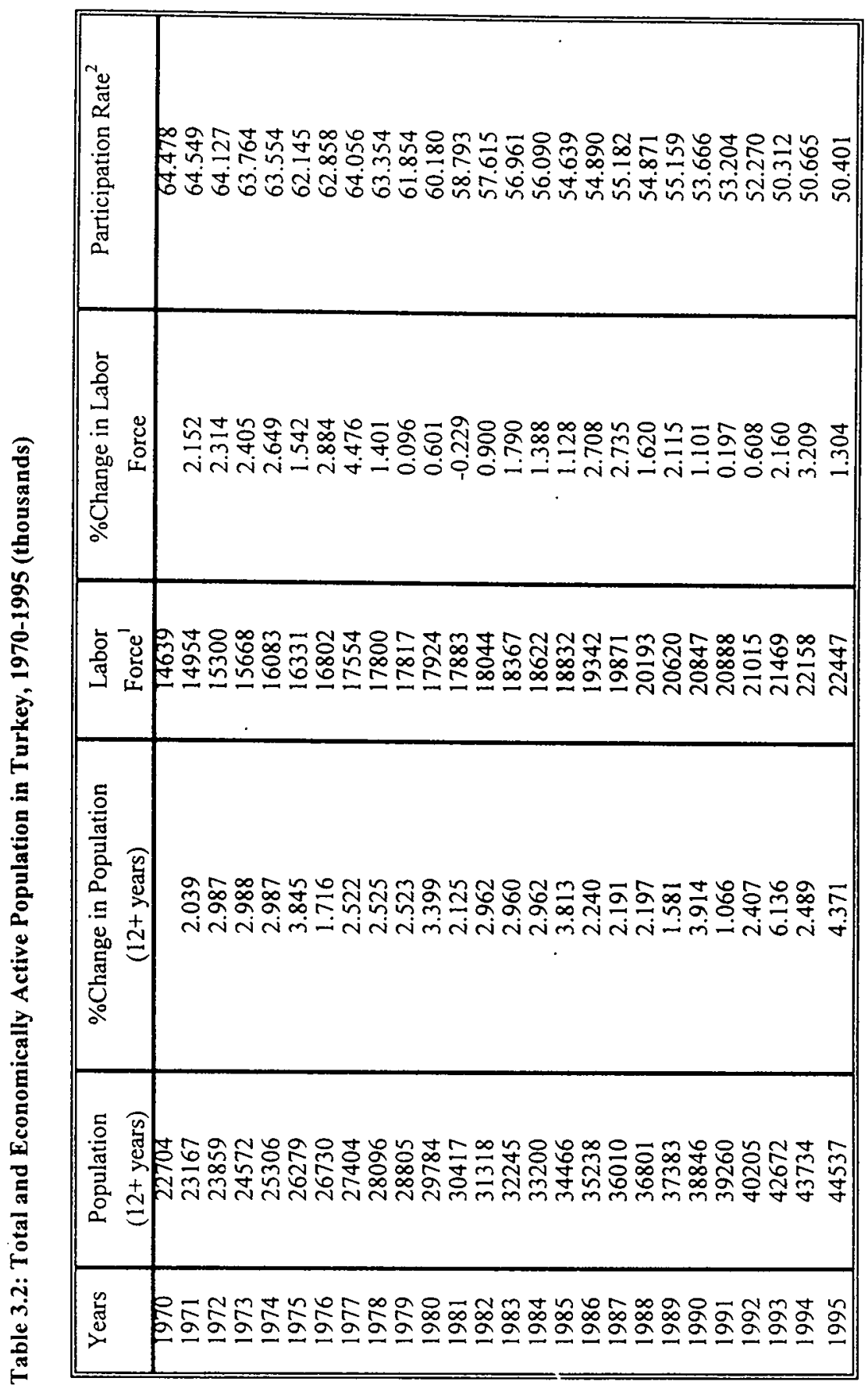




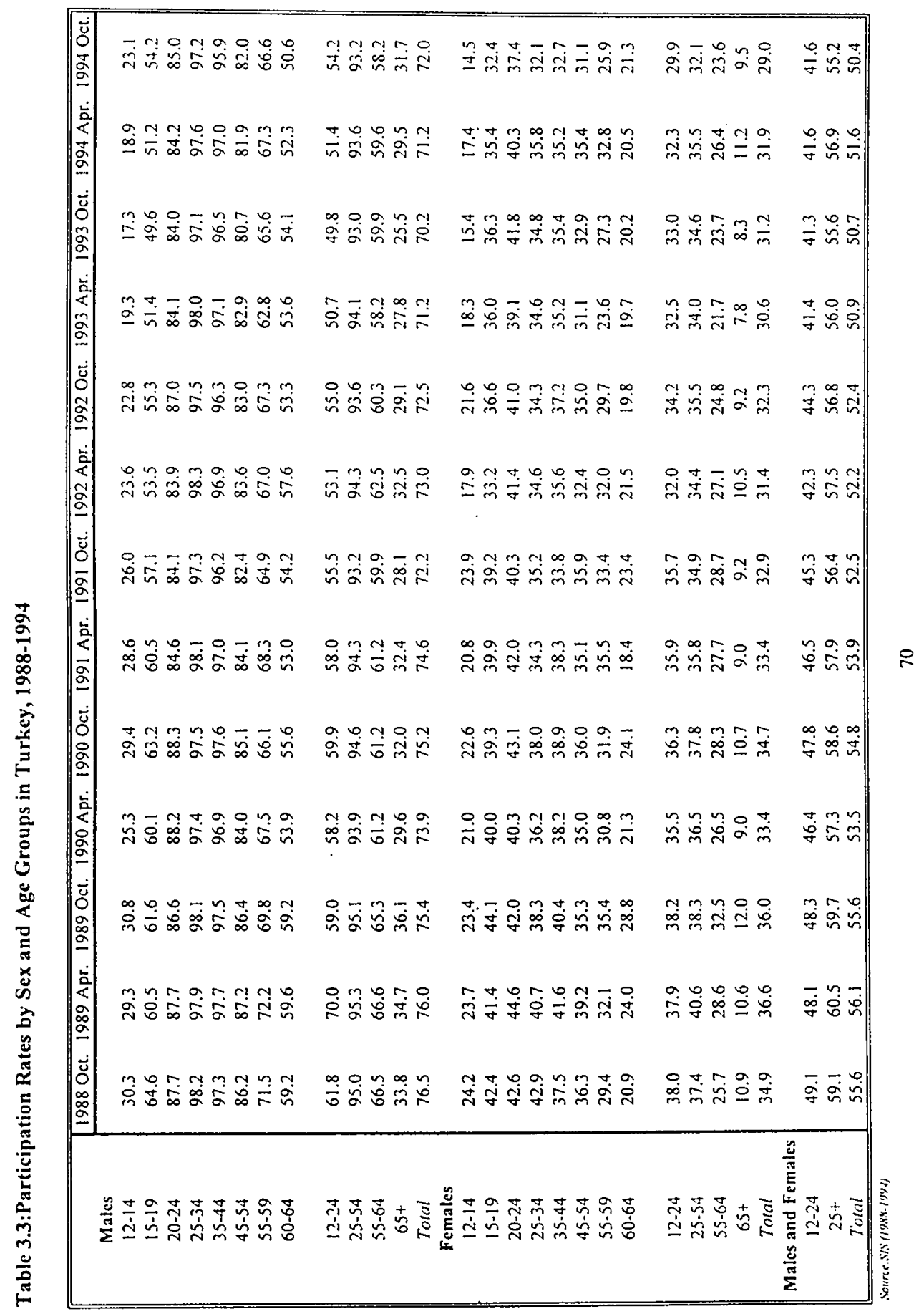


Another point is that male participation rates are significantly higher than female participation rates. This means that women in Turkey do not integrate into the labor market compared to men do. In terms of the age groups, the lowest participation rate for males belongs to the 12-14 age group because of schooling. The participation rate for males increases until 35-44 age group and with higher ages it falls as expected. For women, except the youngest and oldest age groups, the participation rate fluctuates around $35 \%$.

Moreover, we observe a sudden decline after the age group 20-24 which can be the result of marriage and child birth after these ages.

Figure 3.1: Participation Rates by Sex in Turkey, 1988-1994

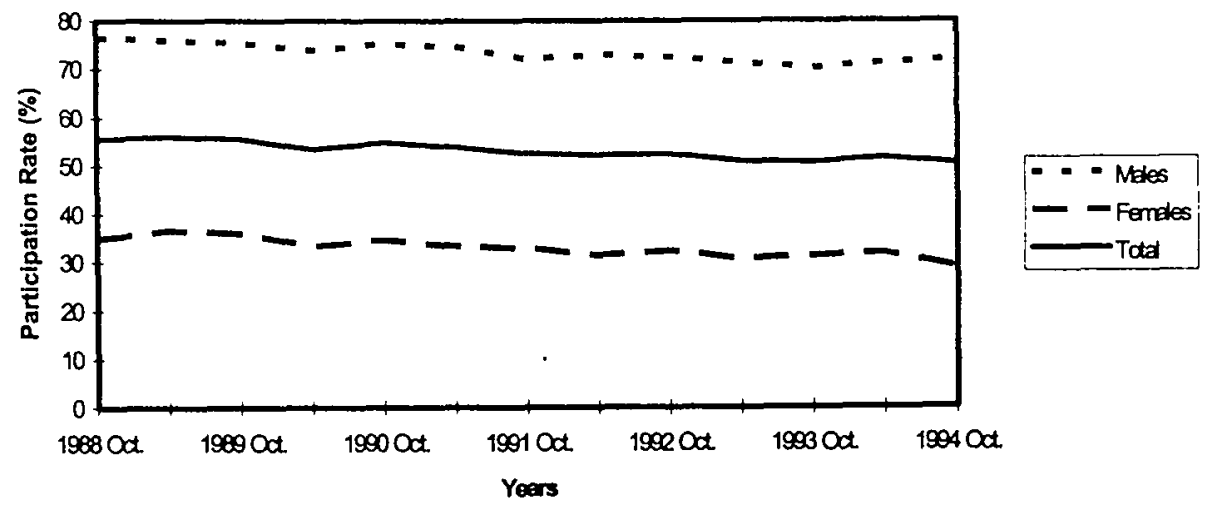

Source: Table 3.3.

Table 3.4: Reasons Given by Non-Participants by Sex and Age for not Seeking Work in Turkey in $1994(\%)$

\begin{tabular}{|c|c|c|c|c|c|c|c|}
\hline & & & Age & & & Sex & \\
\hline & Al1 & Under 45 & & Over 45 & Male & & Female \\
\hline Discouraged & 0.6 & 0.8 & & 0.4 & 1.2 & & 0.4 \\
\hline Seasonal Worker & 1.1 & . 1.3 & & 0.9 & 1.2 & & 1.1 \\
\hline Housewife & 49.3 & 53.9 & & 39.0 & - & & 68.4 \\
\hline Student & 24.3 & 35.8 & & - & 50.7 & & 14.1 \\
\hline Retired & 7.9 & 0.7 & & 23.4 & 24.5 & & 1.5 \\
\hline Having Property Income & 2.0 & 0.4 & & 5.4 & 2.9 & & 1.6 \\
\hline Disabled & 10.6 & 2.1 & & 28.8 & 14.4 & & 9.1 \\
\hline Peronal Reasons & 2.8 & 3.7 & & 1.2 & 3.1 & & 2.6 \\
\hline Other & 1.4 & 1.3 & & 0.9 & 2.0 & & 1.2 \\
\hline
\end{tabular}

Source: SIS(1994) 
Reasons of non-participation given in Table 3.4 may help us to draw a more concrete picture. For all population, the most significant reasons of non-participation are: being housewife, student, or disabled. For the first two reasons, the figures are even higher for persons below 45 years old in line with our expectations. For over 45 , retirement also seems to be an important reason. For men, more than $50 \%$ of nonparticipants are students, being followed by retired and disabled persons. For women, being a housewife replaces being student: almost $70 \%$ of female non-participants give this reason for non-participation.

\subsubsection{Part-Time Employment}

In Turkey, the share part-time employment that is known as more widespread in Western Europe is also increasing in last years. According to the statistics of the SIS, part-time employment corresponds to less than 40 working hours in a week. ${ }^{16}$

Figure 3.2 Share of Part-Time Employment in Turkey, 1988-1995

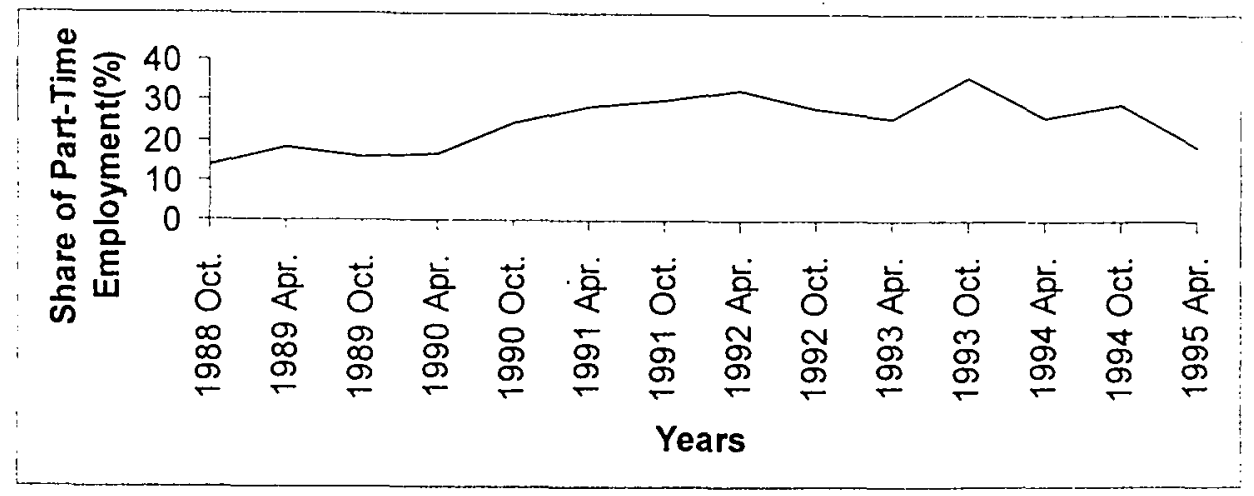

Source: SIS (1988-1995).

The share of part-time employment reached to $35.7 \%$ according to October 1993 statistics and later it felt drastically to $25 \%$. Although we encounter the possibility of the measurement problems in the data, there is an increasing trend after

16 There is a change in the definition of part-time employment in October 1990 statistics. Before this date, it is defined as the ratio of employment less than 40 hours in a week but later it also includes the employment less than 40 hours of work because of the nature of work. Therefore, the figures for part-time employment should be interpreted with reference to this change in the definition of part-time employment and the increasing trend may be misleading. 
$1990 .^{17}$ Moreover, as compared to other OECD countries, we conclude that the relative share of part-time employment cannot be neglected in Turkey (OECD, 1996). The increasing trend is a reflection of flexible working-time policies in the labor market through which a mild increase in available vacancies is also observed.

\subsubsection{Unemployment}

In order to complete our analysis of characteristics of Turkish labor market, we turn to unemployment trends. Turkey has a lower unemployment rate after 1982 compared to OECD average although the rate was considerably higher than this average in 1970s (OECD:1995a). Table 3.5 presents the unemployment rates in Turkey between 1970 and 1994.

Unemployment rate fluctuates until the second half of 1970 s between $6.4 \%$ and $7.6 \%$. However, the effects of the first oil crisis and embargo after Cyprus war were felt in the economy accompanied with political unrest. Therefore, unemployment rates in the second half of 1970 s reached its peak in 1977 with $10.1 \%$ and later it was still higher than the level in early 1970s. In early 1980s, the rate fell down to $7.2 \%$. However, with the effects of liberal policies it was higher than $8 \%$ until 1991 and it seems to be stabilized around $8 \%$ in the 1990 s.

The sex and age composition of unemployed people are shown in Figure 3.3 and Table 3.6 for the period 1988-1994. The unemployment rate for men is lower than for women in 1988 and 1989. This trend is reversed after 1990 and it is significantly lower for women until 1994.

In male and female age groups, the highest figures are observed for the 20-24 age group. Moreover, the figure for the women 25-34 age group is also high. Therefore, on average, more young women are unemployed compared to men. On the other hand, unemployment rate of older age groups among men is higher than the female age groups.

Another point of analysis for unemployment is its duration structure which is presented in Figure 3.4. In 1995, more than $40 \%$ of unemployed persons had been

\footnotetext{
${ }^{17}$ The reason of sharp downturns in the data may be caused by an error of measurement that is frequently faced in the employment data of SIS. However, we estimate the present share of part-time employment as around $25 \%$ in Turkey.
} 
unemployed for more than one year and $65 \%$ of total unemployed persons were looking for a job for more than 6 months. This means that unemployment in Turkey has a long-term character.

Table 3.5: Unemployment Rates in Turkey, 1970-1994(\%)

\begin{tabular}{|c|c|c|c|}
\hline & Unemployment Rate & & Unemployment Rate \\
\hline 1970 & 6.4 & 1983 & 7.9 \\
1971 & 6.8 & 7.8 \\
1972 & 6.3 & 7.3 \\
1973 & 6.8 & 1985 & 8.1 \\
1974 & 7.3 & 1986 & 8.5 \\
1975 & 7.6 & 1987 & 8.7 \\
1976 & 9.0 & 1989 & 8.5 \\
1977 & 10.0 & 1990 & 8.2 \\
1978 & 10.1 & 1992 & 7.8 \\
1979 & 8.9 & 1993 & 7.9 \\
1980 & 8.3 & 1994 & 7.9 \\
1981 & 7.3 & & 7.9 \\
1982 & 7.2 & \\
\hline \hline
\end{tabular}

Source: SIS (1996).

Figure 3.3: Unemployment Rates by Sex in Turkey, 1988-1994

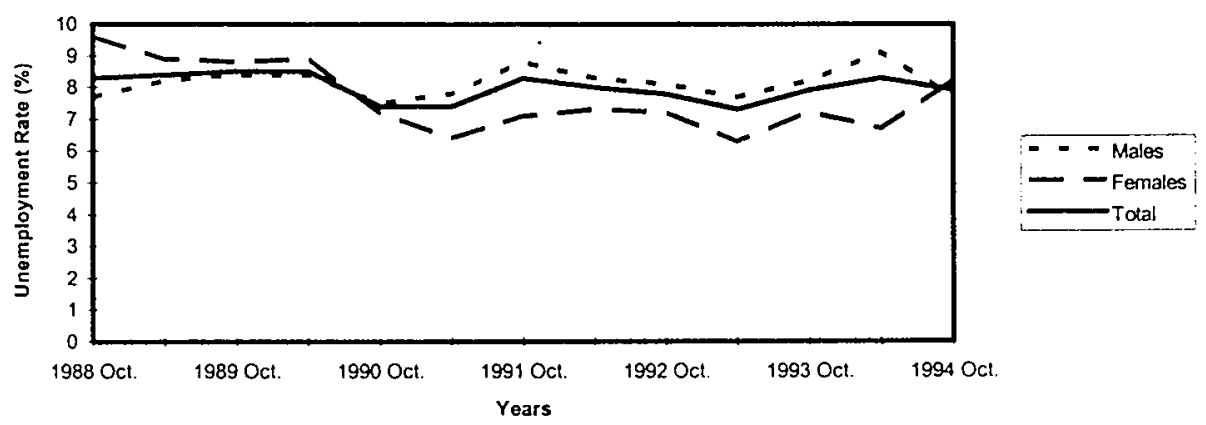

Source: Table 3.6. 


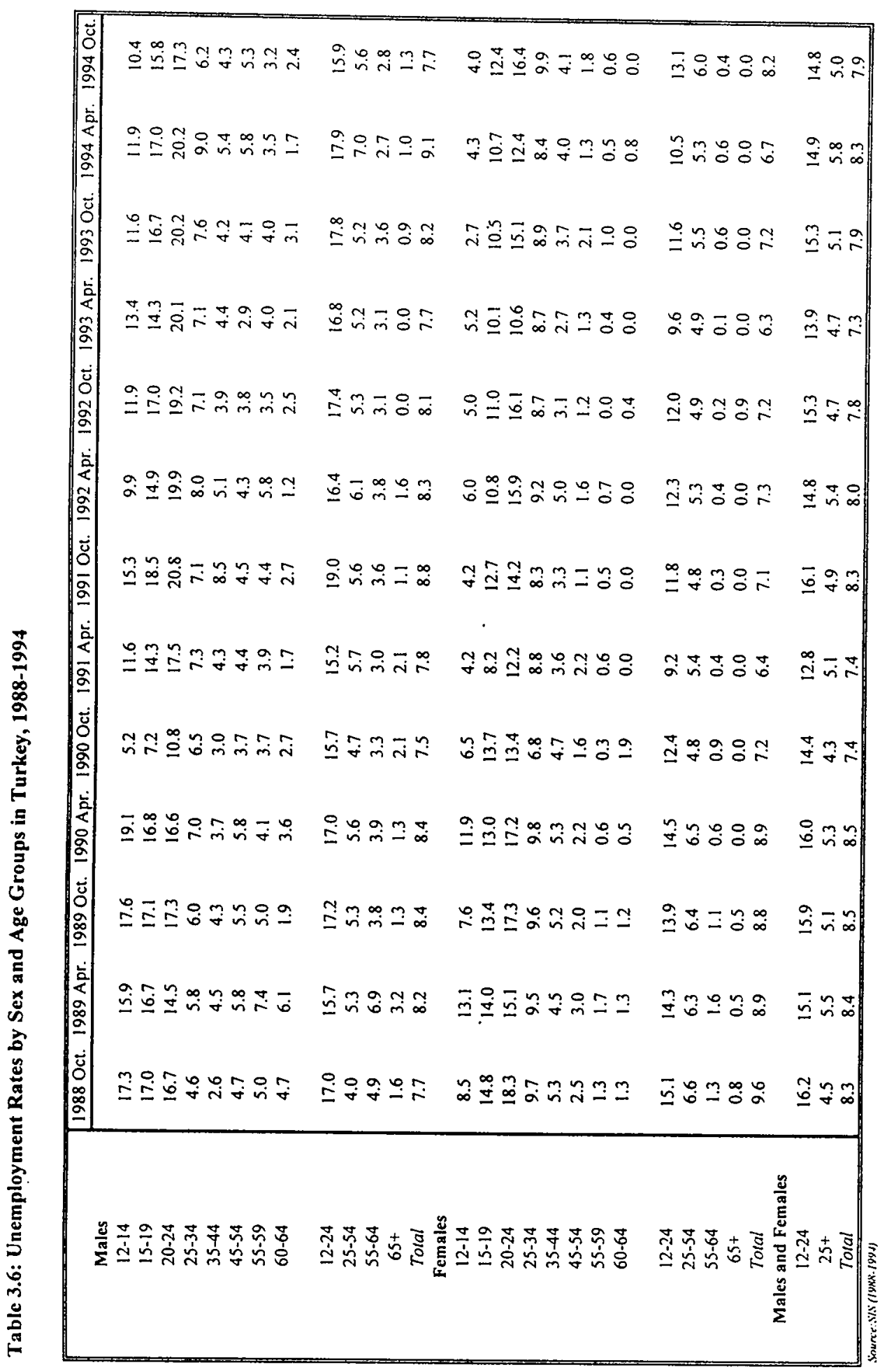


Figure 3.4: Duration Structure of Unemployment in Turkey, 1988-1995

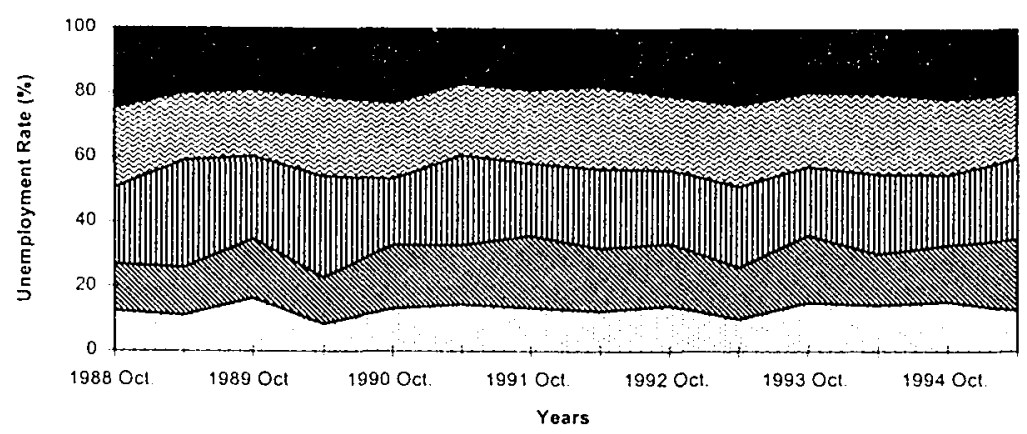

Source:SIS (1988-1994).

Another point of analysis for unemployment is its duration structure which is presented in Figure 3.4. In 1995, more than $40 \%$ of unemployed persons had been unemployed for more than onc year and $65 \%$ of total unemployed persons were boking for a job for more than 6 months. This means that unemployment in Turkey has a long-term character.

Our last point is the relation between vacancies and unemployment. However, a data problem arises. The data are obtained from the Turkish Employment Organization (TEO) and they do not include all the available vacancies. It only covers the reported open vacancies and applications of unemployed people. In constructing the vacancy-unemployment function, we use TEO data for both vacancies and unemployment for completeness of the analysis. ${ }^{18}$ Figure 3.5 sketches the unemployment-vacancy relation.

The gap between vacancies and unemployment opens up drastically with the increase in the number of unemployed until 1989. Later, jt closes with the slow down of unemployed persons. However, one should be cautious in reaching conclusions about the magnitude of the relation because of the reliability of the data. The general conclusion of Figure 3.5 is that there is the tendency of the unemployment-vacancy gap to close. The reason behind this is not the increase in available vacancies but the decrease in the number of unemployed.

18 TEO data of unemployment, covering only reported unemployment figures, thus, difters from the SIS data that covers total population. 
Figure 3.5: Unemployed and Vacancies in Turkey, 1981-1994

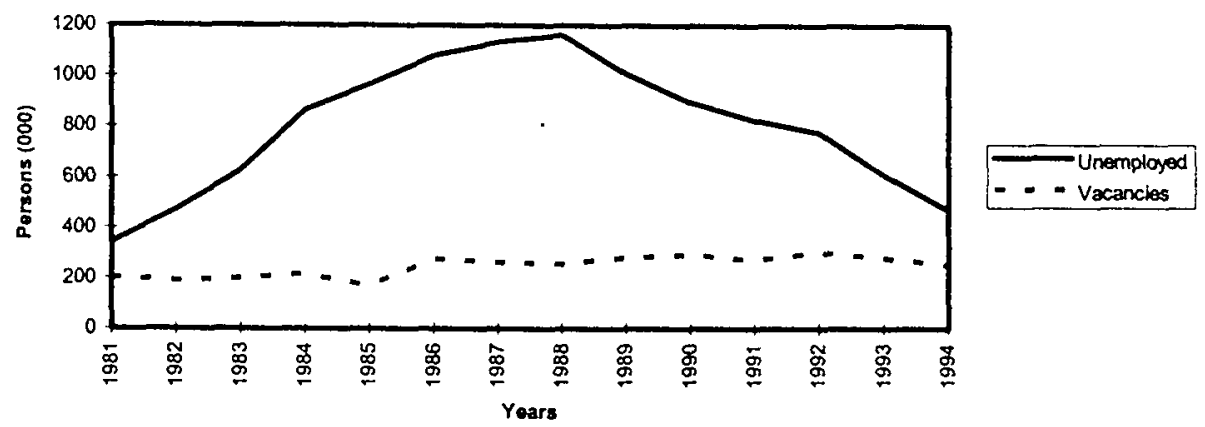

Source: SIS (1995).

In sum, we conclude the following points about Turkish unemployment:

- the unemployment rate is approximately constant around $8 \%$,

- it is higher for men in general. However, it is higher for women in the urban areas while the reverse is true for rural areas (Bulutay, 1995:237-8),

- it is considerably higher in urban places than rural areas,

- the unemployment rate is generally higher among the educated people contrasting sharply with the experiences of developed countries (Bulutay, 1995:238),

- the risk of unemployment for older workers as compared with prime-age workers is low,

- youth unemployment is relatively high,

- long-term unemployment is the predominant characteristic of unemployment,

- it is unlikely that older workers face the greatest risk of long spells of unemployment,

- Turkey is more similar to the European countries rather than the North American countries when the rate of flows into unemployment and the duration of unemployment spells are concerned. 


\subsection{Trends in Employment and Wages in Turkish Manufacturing Industry}

In this section of the study, Turkish manufacturing industry will be examined in terms of the trends in wages and employment and detailed conclusions about the characteristics of Turkish manufacturing industry will be drawn.

\subsubsection{Employment}

We start by the trends in employment shares of industries in Turkey that are given in Table 3.7. The most distinguished trend in Table 3.7 is the continuous decrease in the share of agriculture. Its share decreased from $64 \%$ to $45 \%$ during the period under consideration. On the other hand, the employment share of manufacturing increases slightly from $10 \%$ in 1970 to approximately $15 \%$ in 1994. Manufacturing industry reached it peak in 1992 with more than $15.5 \%$. Moreover, the employment level in manufacturing industry also increases steadily in the same period as can be observed in Figure 3.6. The number of workers employed in manufacturing industry rose by more than 100\% between 1970 and 1994. In 1994, approximately 3 million workers were employed by the manufacturing industry.

Figure 3.6: Employment in Turkish Manufacturing Industry, 1970-1994

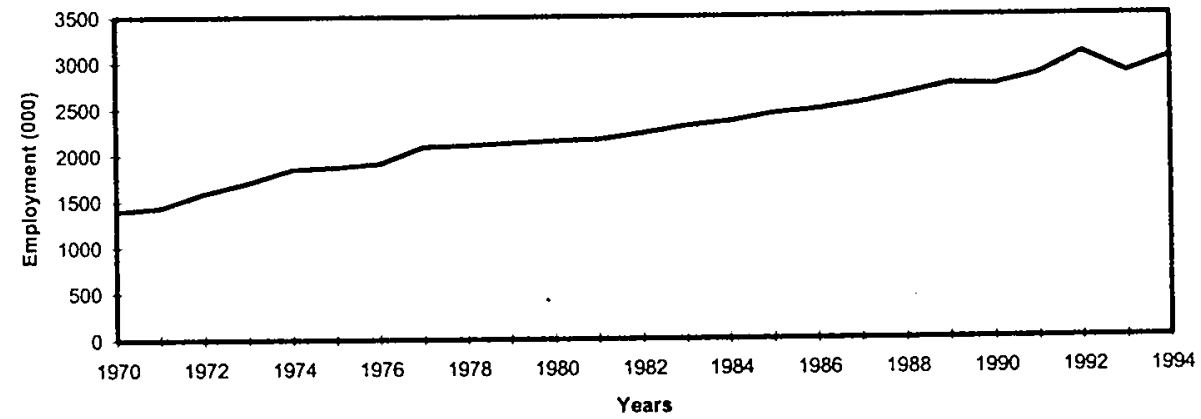

Source: SIS (1970-1995). 


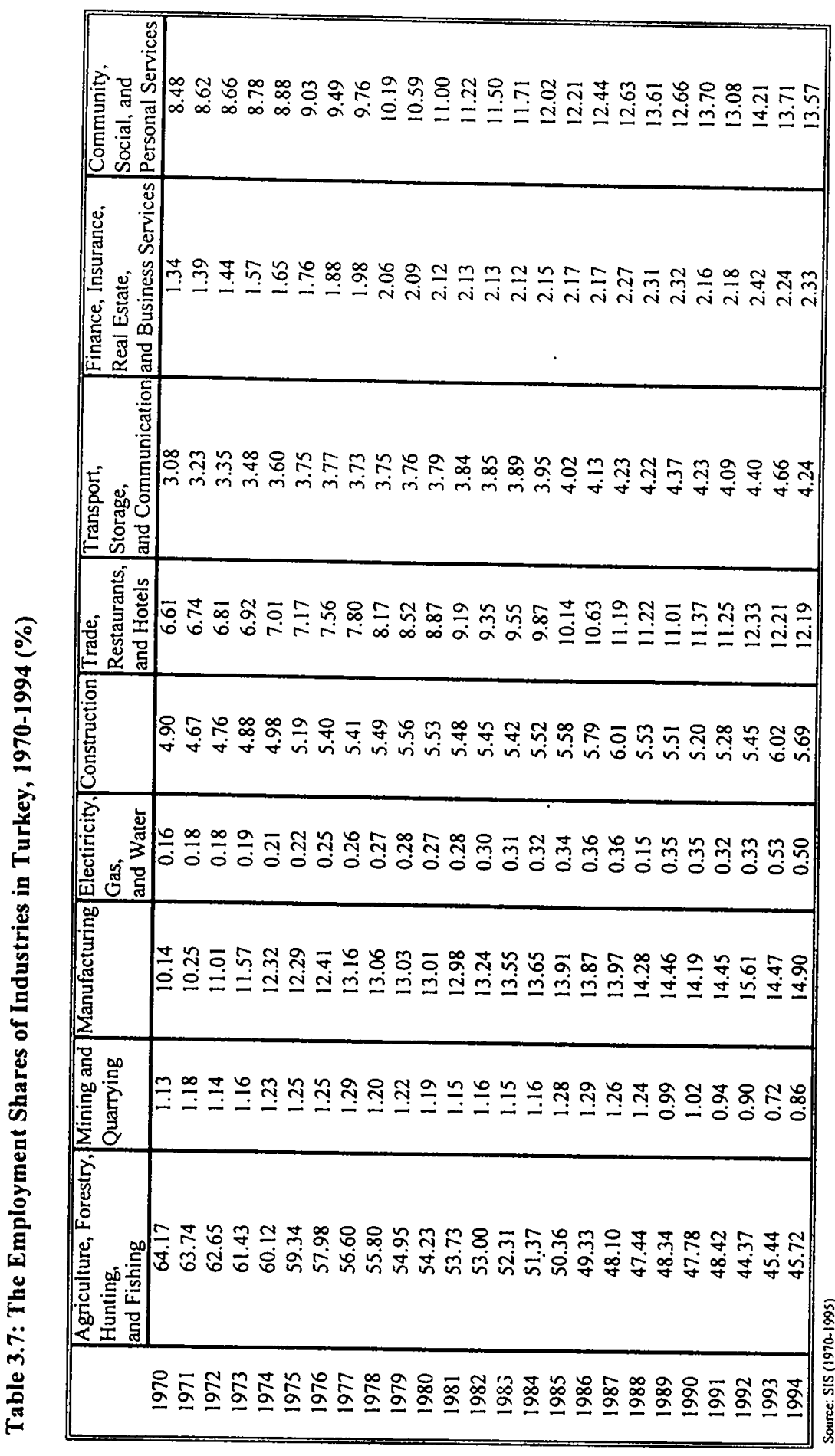




\subsubsection{Wages}

Table 3.8 shows the real wage structure in Turkish manufacturing industry. The low-wage industries are manufacture of furniture and fixtures (332), manufacture of wearing apparel (322), and manufacture of leather and products of leather (323). On the other hand, the dominant high-wage industry is petroleum refineries (353), but manufacture of products of petroleum and coal (354) and manufacture of chemical products (352) are also found among the high-wage industries.

As a measure of wage dispersion, relative deviation in Turkish manufacturing industry is relatively high in 1970s. It then decreases considerably in the 1980s but it has again an increasing trend in the 1990s. The application of liberal and free trade policies and stabilization measures surprisingly cause a fall in wage dispersion in the 1980s.

The changes in real hourly wages are shown in the Figure 3.7. The real wages in Turkish manufacturing industry does not follow a stable path. There are major upswings and downswings in different sub-periods. The first major increase in real wages is observed in the period 1973-1979 when the trade unions are very militant and exert a significant influence in the wage determination process.

Figure 3.7: Real Hourly Wages in Turkish Manufacturing Industry, 1970-1994

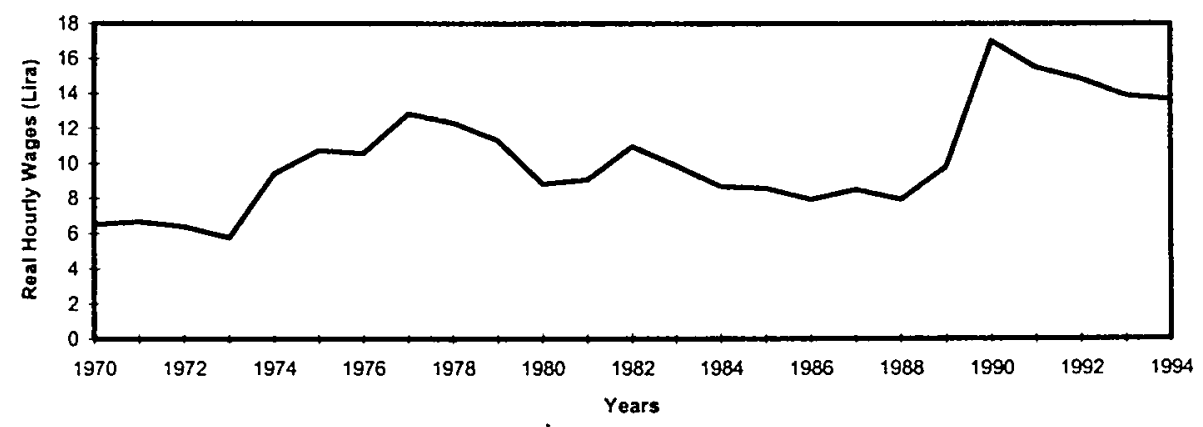

Source: SIS (1970-1995). 
Table 3.8: Wages in Turkish Manufacturing Industry, 1970-1994'

\begin{tabular}{||c|ccccc||}
\hline \multicolumn{7}{|c}{ Mean $^{2}$} & Standard Deviation & Min. $^{3}$ & Max. $^{3}$ & Relative Deviation \\
\hline 1970 & 7.99 & 4.44 & $3.00(332)$ & $24.63(353)$ & 0.56 \\
1971 & 7.01 & 2.48 & $2.67(332)$ & $14.31(353)$ & 0.35 \\
1972 & 7.39 & 4.19 & $2.12(332)$ & $24.71(353)$ & 0.57 \\
1973 & 6.63 & 2.73 & $1.64(332)$ & $16.30(353)$ & 0.41 \\
1974 & 10.35 & 5.20 & $1.98(332)$ & $19.77(353)$ & 0.50 \\
1975 & 11.76 & 6.17 & $2.84(332)$ & $27.96(353)$ & 0.52 \\
1976 & 12.08 & 8.91 & $5.10(332)$ & $52.73(353)$ & 0.74 \\
1977 & 13.71 & 7.15 & $4.24(323)$ & $38.20(353)$ & 0.52 \\
1978 & 14.04 & 8.33 & $4.84(332)$ & $48.30(353)$ & 0.59 \\
1979 & 12.21 & 6.91 & $4.94(385)$ & $41.49(353)$ & 0.57 \\
1980 & 9.27 & 3.83 & $3.27(332)$ & $18.76(353)$ & 0.41 \\
1981 & 10.22 & 4.77 & $3.66(322)$ & $23.25(354)$ & 0.47 \\
1982 & 11.01 & 5.04 & $4.22(322)$ & $28.08(353)$ & 0.46 \\
1983 & 10.89 & 4.27 & $4.81(332)$ & $21.12(354)$ & 0.39 \\
1984 & 9.15 & 3.66 & $3.96(322)$ & $18.27(354)$ & 0.40 \\
1985 & 9.38 & 3.66 & $3.77(322)$ & $18.23(353)$ & 0.39 \\
1986 & 8.64 & 3.50 & $4.31(322)$ & $17.96(353)$ & 0.41 \\
1987 & 9.21 & 3.59 & $4.39(322)$ & $18.58(352)$ & 0.39 \\
1988 & 8.74 & 3.29 & $4.29(322)$ & $18.31(352)$ & 0.38 \\
1989 & 11.47 & 5.27 & $4.65(322)$ & $28.25(353)$ & 0.46 \\
1990 & 14.59 & 6.63 & $5.10(322)$ & $68.83(355)$ & 0.45 \\
1991 & 17.27 & 7.88 & $4.64(323)$ & $36.11(353)$ & 0.46 \\
1992 & 17.26 & 8.45 & $4.69(323)$ & $35.51(353)$ & 0.49 \\
1993 & 16.50 & 8.40 & $4.77(323)$ & $35.92(353)$ & 0.51 \\
1994 & 16.81 & 9.32 & $4.94(322)$ & $42.27(353)$ & 0.55 \\
\hline
\end{tabular}

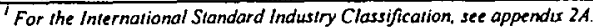

'Real hourb' gross wages

'Figures in parentheses show the ISIC code of minimum/maximum wage industry.

'Relative deviation is the ratio of siandard deviation to the mean wage.

Source: S1S (1970-1995) 
In 1979, real hourly wage rate is almost 2 times bigger than in 1973 . We observe approximately a $15 \%$ fall in real hourly wages during the 1980 s. However, in the 1990s there is a significant increase in real wages. The factor behind such an increase is that 1989 was a year of collective bargaining for $70 \%$ of public employees. Since there is a growing trade union pressure, wage explosion started in the public sector and was triggered by government concern over domestic recession and its declining support (Şenses, 1994:440). Wage settlements in the private sector in the same year follow the paths opened by the public sector. The increasing profit, especially in export-oriented sectors, makes such a rise in real wages possible. With the political concerns of the early general elections, the real wages continued to increase sharply in the 1991 wage rounds (Senses, 1994:440). When compared with the level in 1970, the increase in real wages is more than $100 \%$.

In conclusion, we can say that both share of manufacturing employment and the number of workers employed in manufacturing are increasing from 1970 to present. On the other hand, for wage structure, the low-wage and high-wage industries in Turkish manufacturing industry are more less same for the period 1970-1994. Moreover, wage dispersion has an increasing trend in the last decade. Finally, real hourly wages in Turkish manufacturing industry significantly increase between 1970 and 1994 although there are downturns in sub-periods.

\subsection{Institutions in the Turkish Labor Market}

\subsubsection{History of the Turkish Trade Union Movement}

In this sub-section, the history of Turkish trade unionism will be analyzed after the establishment of the Turkish Republic in $1923 .{ }^{19}$ The new republic did not encourage the right of association despite the liberal provisions of the 1924 Constitution and the Civil Code of 1926. The Restoration of Peace Act of 1925 was not sympathetic to the creation of class-based organizations even though it remained at least theoretically permissible to establish unions outside the public services. The ideology of one-party (Republican People's Party) regime accepted the view that

\footnotetext{
${ }^{19}$ For the chronology of Turkish trade union movement, see the appendix.
} 
Turkey was governed by a unitary state allowing for neither ethnic nor class privileges. Therefore, in the one-party regime between 1923 and 1946, no serious labor organization can be observed.

Turkey's transition to a multiparty democracy just after the World War II marked the beginning of a liberal era for freedom of association in general. The Trade Unions Act of 1947 stressed voluntary unionism and protected basic union freedoms including the right to set up a union without prior permission from the administrative authorities. However, it was limited to manual workers and excluded the white-collar employees from the right to unionize. Unions were expected to put the national interest above their own economic and organizational objectives. They could not be a member of international organizations without the prior consent of government, nor could they engage in politics. Therefore, this legislation brought strict government control over union activities and more importantly it banned strikes and lockouts. Under the impact of this legislation, the structure of Turkish unions began to take shape. The predominant organizational form was the local industrial union that sometimes confined to a single enterprise or to a province or region. Local unions could affiliate with industry-level federations that were loosely structured so as to allow the considerably local decision-making and financial autonomy (Işıkl, 1990:322). At the top were confederations made up of affiliated federations or local unions active in different industries. The significant development in this respect was the establishment of the Türkiye Iş̧̧i Sendikalari Konfederasyonu (Confederation of Turkish Trade Unions- Türk-Is) in 1952. In Democratic Party regime between 1950 1960 , some of the unions, especially the leftist ones, were either closed or subject to legal harassment. By 1958, union membership had reached 262,591 which meant that $37 \%$ of the wage earners covered by the Social Insurance Scheme $(701,231)$ had been organized (Dereli, 1992:468). However, the unionized percentage of total labor force remained low.

After a decade of increasing economic problems and political instability under Democratic Party rule, the 1960 military intervention and the following reformation led by a coalition of intellectuals, bureaucrats, and the armed forces enabled the Turkish trade union movement to gain a new momentum. The Constitution of 1961 guaranteed union freedoms, the right of collective bargaining, and the right to strike. Trade union movement benefited from the softening of government attitudes toward organized labor with the emergent belief that union freedoms and the right to strike 
were indispensable elements of democracy, and the gradual growth of left-wing ideologies in Turkey. Although there was a resistance by employers, the idea of a decentralized decision-making system in industrial relations was adopted. Turkish unions that are equipped with the right to strike started to be involved in collective bargaining. The most significant characteristic of Turkish trade unionism quickly became its emphasis on economic bread-and-butter functions (Koc,1996). Although most political parties sought to bring unions under their influence, the union preferred to remain non-political because of the laws that prohibited unions having direct party links.

An important development both in terms of union structure and of union-party relations was the birth of Devrimci Isçi Sendikalarl Konfederasyonu (Confederation of Revolutionist Trade Unions- DISK) in 1967. Turkish Labor Party played a significant role in the establishment of DISK. In a general convention of Turkish Labor Party, they adopted the idea of forming a union confederation based on party ideology in order to rival Türk-Iss. Following its establishment, DISK started to criticize Türk-İş severely. While DİSK emphasized the political side of unionism, its affiliates often proved to be efficient in the bread-and-butter aspects of unionism as well. However, DISK was not successful as was expected at its inception. The lack of a structured class-consciousness and the conservatism of the working class made most workers reluctant to identify themselves with the leftist groups. Therefore, DISK activism was largely confined to the leadership levels. On the other hand, Türk-Is treated the formation of DISK as a setback of Turkish trade unionism. It claimed that DISK worsened the disease of union inflation by dividing the labor movement and the factionalization of the labor movement caused the existence of many ineffective unions (Koc, 1996:350).

By 1980 , there were more than 750 unions with a total of approximately 2 million members. Half of these unions were federations and industry-based national organizations, the other half being local unions. However, national unions were mostly confined to a particular region and had very limited membership. Türk-İs was the largest confederation with its 1.5 million members. DISK was the second with around 450,000 members. There were two other confederations; Türkiye Milliyetçi Isçi Sendikalarl Konfederasyonu (Confederation of Nationalist Trade Unions of Turkey-MISK) and Türkiye Hak Isçi Sendikalar Konfederasyonu (Confederation of Righreous Trade Unions of Turkey- $\left.H A K-\dot{I}_{S}\right)$. Both were right-wing confederations but 
their membership was negligible. While union density was approximately $40 \%$ of the nonagricultural and potentially unionizable of work force around 5 million, computed in relation to the total labor force it was only about $10 \%$. About 1,000 collective agreements were concluded each year and of 2 million unionized workers, approximately half were covered by these agreements.

As a result of economic and political problems and political violence, a military coup d'etat took place in September 1980. The military National Security Council suspended the activities of several unions and banned strikes and lockouts. There was a transitional period during which the Supreme Arbitration Board reactivated number of expired collective agreements after revising wages and fringe benefits. The 1982 Constitution placed major restrictions on the political activities of the unions. Unions were forbidden to pursue political objectives, engage in political activities, establish relations with political parties, or use the name or symbols of political parties. Despite legal harassment, however, Turkish unions have frequently engaged in various forms of political activity, justifying their political involvement by arguing that they were simply furthering the economic and social status of their members as permitted by the law. Although the union structure has been centralized at the industry level, the focus of collective bargaining has been confined to local levels. Moreover, the requirement that a union, in order to be entitled to bargain on behalf of a plant or company, must represent at least $10 \%$ of the workers in the industry and more than half of the workers in the plant or company, has tended to curb the freedom to bargain without impediment of smaller, newly established unions, a circumstance that has become a major issue in union and ILO circles. However, there has been a tendency for multi-employer or group bargaining to become more common in the course of time. Particularly in the public sector, entire branches were covered by concurrent company agreements, thus in effect creating an industry-wide agreement. The distinguished feature of Turkish trade unionism is that its emergence and development have been brought about by legislation borrowed in an eclectic way from the industrial relations systems of various European countries. Although there are periods of political militancy in some segments of Turkish trade unionism, its main focus has been on its bread-and-butter function.

In the post-1980 period, Turk-İs was still the leading confederation in terms of membership as can be seen in Table 3.9. Almost $75 \%$ of all unionized workers is member of an union that is a member of Türk-Is. The second biggest confederation is 
HAK-Is and its share fluctuates around $10 \%$. DISK which is the left-wing confederation has been reestablished after a court decision in 1992 and reorganized in a relatively short period of time but could not reach the membership levels of the pre1980 period. However, its share is more than that of HAK-Iş between 1994 and 1996. MISK was also reestablished in 1994.

By the beginning of 1991, despite reductions of the number of unions through forced mergers, total union membership had reached its pre-1980 level of just over 2 million. At that time, union density in terms of total labor force remained at around $10 \%$, but in terms of the potentially unionizable work force it reached approximately $58 \%$ according to the statistics of Ministry of Labor and Social Security (MLSS) as can be seen in Table 3.10 .

Union density rate and annual change in membership have increased significantly between 1984 and 1985 because of the relaxation of prohibitive decisions of National Security Council on freedom of unionization and the impact of promulgation of new legislation in 1983 as it will be explained in the next section. It reached almost $65 \%$ in the beginning of 1989. A sudden fall is observed in 1989 because of some amendments in law. Union density rate has gradually increased until 1995 and reached $70 \%$ by the end of 1994 . In the last two years, a smooth fall in the rate is seen and it equals $66 \%$ in 1997 . The change in union membership has followed the same path. The highest increase is observed in the mid of $1980 \mathrm{~s}$ and in the mid of 1990 s.

We conclude that Turkish trade union movement and industrial relations system moved from a restrictive arena to a more liberal and democratic one from 1923 to 1980 and gained an important momentum in the period between 1961-1980.

Unfortunately, after the military intervention in 1980, all gains of trade union movement have been curtailed especially in the first half of 1980 s. Later on, with the effects of forceful agreements with ILO and reorganized labor, a new phase in Turkish trade union movement started.

Although the union structure has been centralized at the industry level, the focus of collective bargaining has been confined to local levels. Among the confederations of unions, Türk-İs has a leading role in terms of the magnitude of union membership. Union density rates and annual change in membership increase in the last decade with some exceptions but the rate of change in union membership slow down in last years. 
Table 3.9: Membership Share of Recognized Confederations in Turkey, 1984-1997 (\%)

\begin{tabular}{||l|cccccc||}
\hline & Türk-i\$s & DiSK $^{\prime}$ & HAK-I\$s & MiSK $^{2}$ & Independents & Other $^{3}$ \\
\cline { 2 - 6 } January 1984 & 79.85 & & 8.38 & & 11.52 & 0.25 \\
July 1984 & 80.42 & & 7.42 & & 11.67 & 0.49 \\
January 1985 & 79.92 & & 7.34 & & 12.05 & 0.69 \\
July 1985 & 74.13 & & 7.07 & & 11.16 & 7.64 \\
January 1986 & 74.29 & & 7.52 & & 10.86 & 7.33 \\
July 1986 & 73.62 & & 7.63 & & 11.44 & 7.31 \\
January 1987 & 73.73 & & 7.88 & & 11.33 & 7.06 \\
July 1987 & 74.01 & & 7.94 & & 11.20 & 6.85 \\
January 1988 & 74.72 & & 8.12 & & 11.69 & 5.47 \\
July 1988 & 75.03 & & 8.11 & & 11.67 & 5.19 \\
January 1989 & 75.77 & & 9.04 & & 12.92 & 2.27 \\
July 1989 & 77.45 & & 9.08 & & 13.36 & 0.11 \\
January 1990 & 77.71 & & 9.69 & & 12.56 & 0.04 \\
July 1990 & 78.47 & & 9.47 & & 12.03 & 0.03 \\
January 1991 & 78.79 & & 9.59 & & 11.62 & \\
July 1991 & 78.62 & & 11.72 & & 9.66 & \\
January 1992 & 78.62 & & 15.08 & & 6.30 & \\
July 1992 & 78.36 & 0.86 & 11.89 & & 8.89 & \\
January 1993 & 76.20 & 3.46 & 11.49 & & 8.85 & \\
July 1993 & 73.03 & 8.38 & 10.96 & & 7.63 & \\
January 1994 & 71.35 & 12.65 & 10.68 & & 5.32 & \\
July 1994 & 74.39 & 12.66 & 10.71 & 0.23 & 2.01 & \\
January 1995 & 74.36 & 12.40 & 10.78 & 0.28 & 2.18 & \\
July 1995 & 74.17 & 12.35 & 11.09 & 0.16 & 2.23 & \\
January 1996 & 74.30 & 11.76 & 11.48 & 0.16 & 2.30 & \\
July 1996 & 74.37 & 11.56 & 11.71 & 0.14 & 2.22 & \\
January 1997 & 74.12 & 11.50 & 11.90 & 0.14 & 2.34 & \\
\hline
\end{tabular}

'D/SK is banned from all union activities untul the court decision in 1992.

'MISK is banned from all union activitic.r unit the courl decision in 1992.

'Other confederations are liquidared hecause of recosnnision problem.

Surce: MISi: 1984.1907 


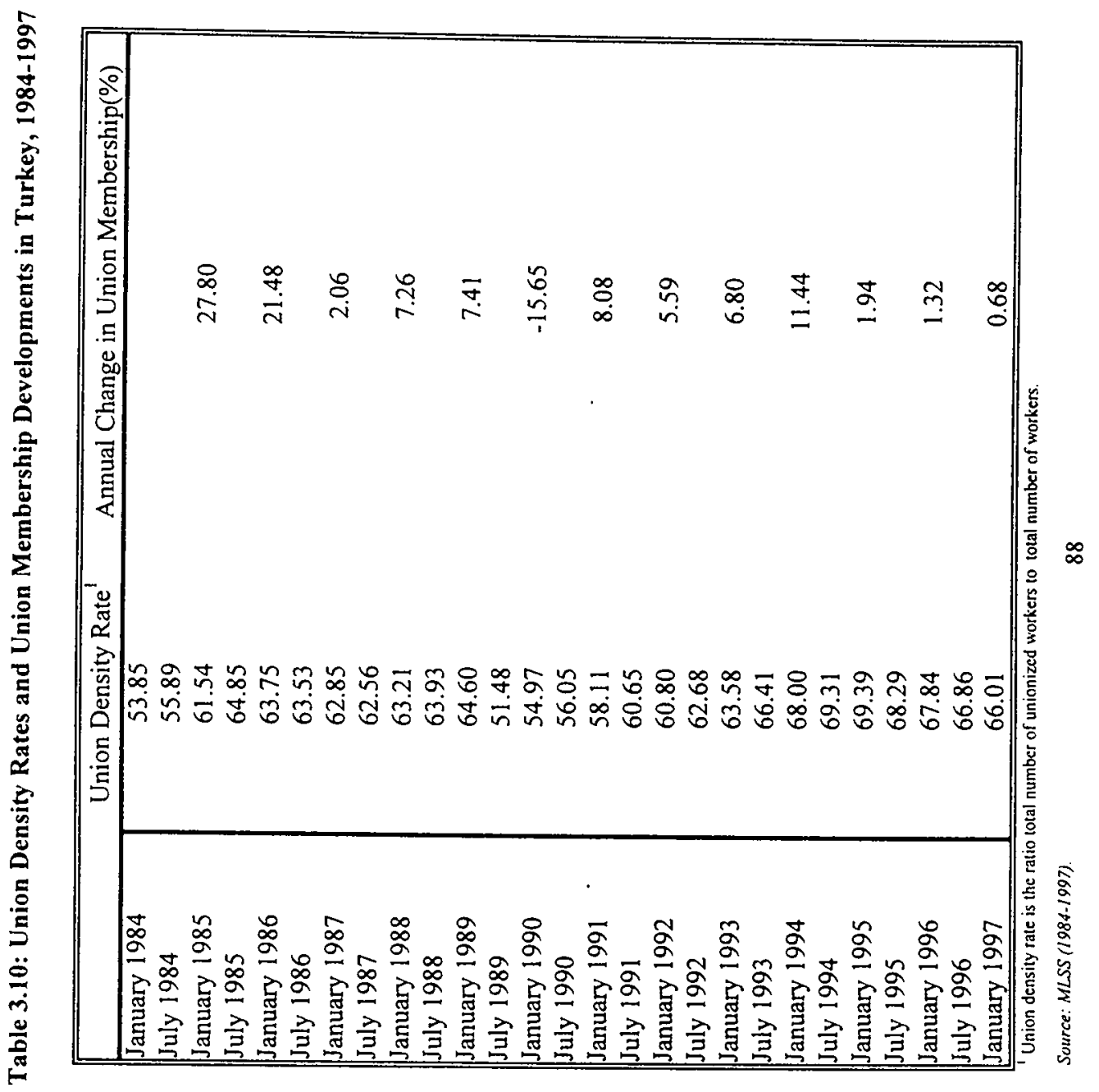




\subsubsection{Employers' Associations in Turkey}

In Turkey, the employers began to organize later than employees. The 1961 Constitution gave right to organize not only to workers but also to the employers. The number of employers' associations in a historical perspective is presented in Table 3.11 .

We observe that although employers were late to organize as compared to workers the number of employers' associations rose rapidly following the changes brought by the 1961 Constitution. In 1982, with the new constitution and legislation, a tremendous decrease in the number of employers' associations has been witnessed because of limitations prescribed by the new legislation. In 1990s, the number is stable around 55 associations.

Moreover, the distribution of employers' associations in terms of economic activity gives some clues about in which sectors employers are more organized. This data is at Table 3.12 .

It seems that the employers are highly organized in the food industry. Following the food industry, petroleum, chemicals, rubber, construction, textile, cement, clay, and glass employers are also significantly organized whereas in 12 out of 28 industries there is no employers' organization.

The first central organization was established at the end of 1961, named as İstanbul İşveren Sendikaları Birliği (İstanbul Assembly of Employer AssociationsIISB) with involvement of 6 associations in metal, wood, textile, food, printing, and glass and cement. Later, IISB organized throughout the whole country and its name was changed to Türkiye İşveren Sendikalan Konfederasyonu (Turkish Confederation of Employer Associations-TISK) in the end of 1962. Today, it is the only employers' association which has the right to conclude collective labor agreement with trade unions and has 17 member associations both in private and public sector. 
Table 3.11: Number of Employers' Associations in Turkey, 1963-1996

\begin{tabular}{|c|c|}
\hline & Number of Employers' Associations \\
\hline 1963 & - \\
\hline 1964 & 92 \\
\hline 1965 & 95 \\
\hline 1966 & 104 \\
\hline 1967 & 108 \\
\hline 1968 & 104 \\
\hline 1969 & 110 \\
\hline 1970 & 120 \\
\hline 1971 & 109 \\
\hline 1972 & 98 \\
\hline 1973 & 104 \\
\hline 1974 & 101 \\
\hline 1975 & 107 \\
\hline 1976 & 106 \\
\hline 1977 & 118 \\
\hline 1978 & 116 \\
\hline 1979 & 104 \\
\hline 1980 & 106 \\
\hline 1981 & 104 \\
\hline 1982 & 102 \\
\hline 1983 & 102 \\
\hline 1984 & 60 \\
\hline 1985 & 48 \\
\hline 1986 & 46 \\
\hline 1987 & 48 \\
\hline 1988 & 49 \\
\hline 1989 & 49 \\
\hline 1990 & 49 \\
\hline 1991 & 52 \\
\hline 1992 & 51 \\
\hline 1993 & 54 \\
\hline 1994 & 54 \\
\hline 1995 & 54 \\
\hline 1996 & 55 \\
\hline
\end{tabular}

Source: MLSS (1997). 


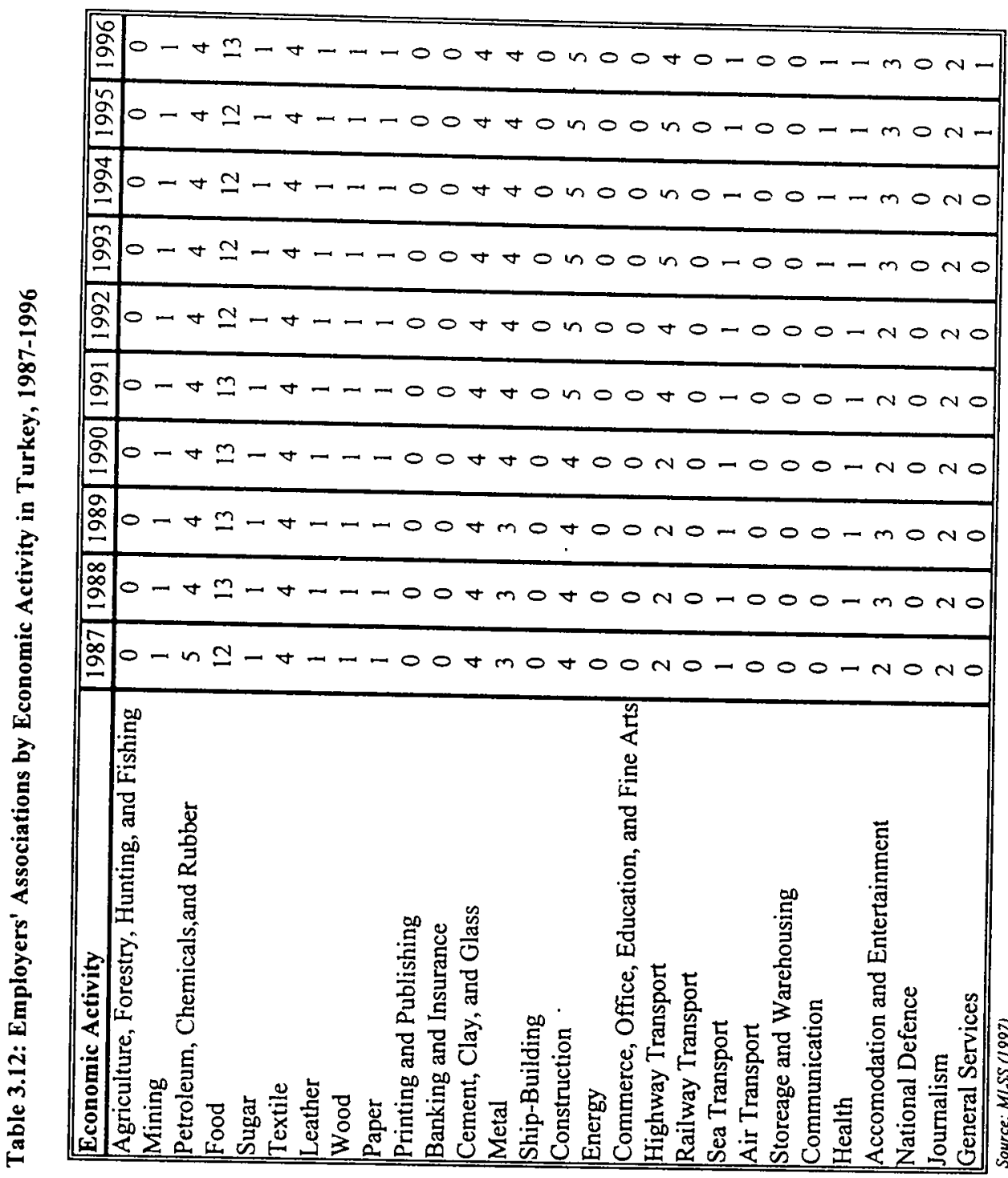


The basic principles of TiSK are as follows (TISK,1985:6-7):

- to establish and stimulate the peace in industrial relations, operate in accordance with the basic principles of republic,

- to support the parliamentarian democratic regime,

- to support the free entrepreneurship and free market economy as a part of this regime,

- to target industrialization and endure the development of agricultural and services sector,

- to cooperate with the relevant institutions to increase the productivity, to expand the volume of exports, to create employment opportunities, and to increase the welfare of whole society,

- to protect the social and economic rights of employers and employers' associations in the framework of the legislation,

- to coordinate lobbying activities in order to solve the social and economic problems of employers and to meet the needs of them,

- to protect the peace and consensus in industrial relations by establishing balanced ties between employers and employees,

- to emphasize the importance of vocational and technical education in order to speed up the industrialization process, to increase the competitive power in the world markets, and to meet the needs for qualified labor force,

- to push for a tax system which maintains incentives and savings,

- to advocate privatization in accordance with the national interests,

- to defend future of EU membership both at national and international levels and integration with Western economies,

- to initiate in activities for solving environmental problems.

The influence of employers' associations in the labor market in particular and in the economy in general declined especially after 1970. The most important gains of employers' associations were realized in the years just following the 1980 military intervention. They were really effective in the preparation of new legislation and almost all their requirements were put into new legislation. The way of conclusion of collective labor agreements has changed after 1980. In the pre-1980 period, the basis of collective labor agreements were both workers' and employers' demands were discussed in accordance with workers' demands. However, after 1980, the situation 
changed in the reverse direction and bargaining took place according to the drafts prepared by the employers' associations. Therefore, in collective labor agreements and in new legislation, the balance of powers has shifted in favor of employers in 1980 s and 1990s.

\subsection{The Legal Framework of Turkish Industrial Relations}

In this section, Turkish collective labor law will be discussed in a historical perspective. Following the proclamation of the Second Constitution of 1908 in the last years of Ottoman Empire that recognized the right of association, an outbreak of strikes occurred in İstanbul mainly against foreign-operated establishments. These were mainly in railways, public transportation, and public utilities and they took the form of general strikes and spread to other cities as well. The Unity and Progress Party government reacted by suppressing these work stoppages and promulgated the Work Stoppage Act of 1909. This act closed existing unions and prohibited the establishment of new ones in public services and utilities. This law that remained in force until 1937 was the first legal barrier to labor organization in Turkey.

In 1923, delegates representing farmers, traders, industrialists, and laborers assembled in İzmir to lay down the essentials of the new regime's economic policies. In this congress, the representatives of the working class demanded a new labor law. The draft of labor bill was prepared in 1924 but it could not be enacted in the face of opposition from those who insisted on a more comprehensive and protective labor code. However, in 1924 Weekly Holiday Act which allowed workers to have one day holiday in a week was promulgated. Another development was the new Act of Obligations of 1926 and with this law the Islamic principles in the employeeemployer relations were discarded. This law enabled the enactment of collective labor agreements between employers and organizations of workers in the following years.

In 1934, a draft of labor bill was prepared and it was enacted in 1936. It remained in force until the late 1960s. The coverage of the 1936 Labor Act was limited to manual workers. This act tightened the existing restrictions on work stoppages, and it laid down a full-fledged conciliation and compulsory arbitration mechanism. Based on provincial arbitration boards whose rulings could be appealed to Supreme Arbitration Board, the mechanism could be activated by the elected representatives of the workers under prescribed conditions. At least one fifth of the 
workers (not less than 10) in an establishment could apply to the Provincial Arbitration Board for the investigation of working conditions, their implementations, and collective labor agreements. If this board could not solve the problem, one of the parties had right to apply to Supreme Arbitration Board and decisions of this board were final. This system created the backbone on which unionism with collective bargaining could subsequently develop. The rationale for banning unions and strikes under the 1936 Act was the populist approach of the ruling Republican Peoples' Party which insisted that labor's interests were well protected by the classless and paternalistic state.

After the Second World War, in June 1946, the Act of Associations were amended and the prohibition on establishing class-based associations were removed. Following this amendment new unions were established in a short period of time. However, all of these unions were closed in December 1946 by the government. Trade Unions Act of 1947 was promulgated and it established basic union freedoms as explained in the previous section. However, like the 1936 Labor Act, it only covered the manual workers and excluded white-collar employees from right to unionize. The only exception was the journalists who were covered by a special legislation enacted in 1952. The most important deficiency of this law was its banning of strikes and lockouts. Therefore, the period 1947-1960 can be named as labor unionism without the right to strike.

In the 1950s, there were other important changes. In order to deal with disputes of rights, labor courts were formed by an act in 1950. In the same year, a special legislation empowered unions, along with elected workers' representatives, to file collective labor disputes with compulsory arbitration boards, and thus to conclude wage agreements with employers. Following this amendment, unions became quite active in settling labor disputes under the compulsory arbitration scheme.

The Constitution of 1961 brought union freedoms, right to strike, and collective bargaining. In 1963, in order to arrange these rights prescribed in the Constitution, two acts on unions and collective bargaining were promulgated. These acts covered both manual and white-collar workers. Although both laws were more liberal than the previous codes, there were still some limitations on union freedoms. All political and financial relations with political parties were banned. Moreover, strikes with political nature and general strikes were also forbidden. Another problem was related with which union in an industry would be qualified to sign a collective 
labor agreement. This problem that can be named as qualification problem was a major drawback of the new Collective Bargaining Act since later it led to abuses. The Collective Labor Act of 1963 gave the duty of determination of the qualified union to sign collective labor agreement in a work place to Ministry of Labor but it did not definitely state the conditions for the determination of the qualified union. In application, the Ministry of Labor decided it according to the number of members and gave right to sign the collective labor agreement to the union with the highest number of members. This application caused fraud against law such as double-membership, abuses in the date of membership of forms, etc. and many cases related with these abuses were brought to labor courts (Ketenci, 1987:162).

In line with the 1961 Constitution, an act concerning the formation of unions by civil servants was passed in 1965 , but, because they were reluctant to the right to strike and bargain collectively, most of the civil servants' unions remained insignificant. One of the strong exceptions to it was the teachers' unions and they became actively involved in left-wing politics and consequently were susceptible to occasional harassment by the government. The transitional government formed during the 1971 military intervention effected certain changes in the 1961 Constitution, including abolition of the right of civil servants to organize. Following this constitutional amendment, the legislature repealed act on civil servants' unions, depriving an important portion of public employees of right to unionize.

The entire body of legislation led to the establishment of an industrial jurisprudence system and principles to cover employee-employer relations. Collective bargaining determined not only wages and fringe benefits of workers but also the administration of discipline and layoffs as well as the settlement of grievances. The accumulation of judicial rulings and the decision of arbitration boards made Turkish industrial relations both splendid and complex within a short period of time. However, both legal and practical problems remained intact in the Turkish system.

Following the military intervention in 1980, the military National Security Council suspended the activities of unions and forbidden all strikes and lockouts. Between 1980 and 1983, Supreme Arbitration Board decided upon the expired collective labor agreements. In mid of 1983, by the enactment of Unions Act and Act on Collective Agreements, Strikes, and Lockouts, a new phase of industrial relations started in Turkey. Together with the Labor Law of 1971 which deals with the individual employment relationships, these two acts, as amended in 1986 and 1988, 
established the legal framework of present labor relations in Turkey. This legislation covered all manual and white-collar workers in both the public and private sectors with some minor exceptions. However, civil servants did not have right to unionize and to bargain collectively. This legislation aimed to exhaust the abuses and malfunctioning of the previous legislation but this affirmative action in some sense brought some other negative effects on union freedoms. New legislation imposed some limitations on membership, instituted heavier penalties for abuses, further restricted strikes, and expanded the scope of compulsory arbitration. Most of the new regulations were based on the articles of 1982 Constitution in which right to unionize and right to strike were explained in a detailed manner. For example, even the qualifications of the administrators of unions were specified in the Constitution. Moreover, unions establishing any sorts of ties with political parties, associations, and other professional organizations were again banned by the Constitution. The Constitution also prohibited work stoppages, political, solidarity, and general strikes and lockouts.

With these respects, the new legislation is an irony since efforts to correct the abuses of the past by creating a centralized structure, speeding up the bargaining process, eliminating fraud by unions, and strengthening union democracy, in fact, caused new malfunctions, among them intertwined rules, entangled procedures, and complicated time periods to be observed if unions were not to incur penalties or lose bargaining rights. The endeavors to draw a trade union picture through legislation mainly concentrated on building a centralized structure and on reducing the number of unions. In order to accomplish this target, national and industrial unionism was declared as the basic organizational principle. Furthermore, the number of industries according to which unions might be organized was decreased from 32 to 28 . The condition that at least five unions active in different industries must come together to found a confederation served to build a less factionalized organizational framework.

Complicated rules for mediation and detailed regulations relating to strikes are other characteristics of the post-1980 system of industrial relations. Furthermore, another characteristic of new legislation on strikes and lockouts is its more restrictive approach. Strikes and lockouts must have been called by the competent parties and conducted in conformity with the rules. Their aim must be work related. Moreover, general strikes, sympathy strikes, politically motivated strikes and lockouts, work slowdowns, sit-ins are considered as illegal. The present legislation expanded the 
scope of restrictions on strikes as compared to the previous legislation of 1963. For establishments or activities where strikes and lockouts were forbidden, the legislation defined a compulsory arbitration mechanism to follow the mediation process. Approximately $20 \%$ of the unionized workers is engaged in areas subject to compulsory arbitration (Dereli, 1992:472). It is really a high ratio in a country committed to free collective bargaining and the right to strike. Moreover, in the application, it was observed that mediators were not chosen from the labor law academicians by the ministry instead the advisors of the employers' associations were chosen and, because of this, unions treated mediation process as costly and timeconsuming (Ketenci, 1987:191). Türk-İs has also criticized the composition of Supreme Arbitration Board by arguing that workers are underrepresented and this leads to decisions against workers' interests.

There are also other restrictions on the right to strike. Strike and lockouts are not permitted during a state of war or full. and partial mobilization, and they may be forbidden in the case of major disasters negatively affecting daily life. They can be temporarily restricted in the case of martial law or extraordinary emergency law conditions. Furthermore, a legal strike or lockout considered likely to endanger public health or national security may be suspended for sixty days by a government order and taken to compulsory arbitration at the end of this period, if the parties of the dispute have not reached an agreement.

In conclusion, the target to create a centralized structure of unionization is reached by the mechanism prescribed in the new legislation. Furthermore, the restrictive rules and the regulations on the application of strikes seriously exhausted the right of using strikes as a tool to conclude collective agreements quickly in favor of workers since the nature of strikes to force employer to conclude the agreement is deformed by the new legislation. Therefore, legislation of 1983 is a step backward in terms of the rights of workers gained in 1960s.

\subsection{Revisiting Turkish Labor Market}

Turkish labor market suffered from the lack of policies directed to labor market during a long period of time. It was considered as a small section in broad macroeconomic policy prescriptions. In the last decade, serious efforts first made to formulate policies towards labor market. The most radical changes as in every market 
of the economy were experienced after 1980 with the introduction of structural adjustment policies. Wage restraint in the sake of demand restraint and competitiveness in the international trade was used as an important tool to reach some macroeconomic objectives. In the late 1980 s, the direct policy measures, such as education and vocational training, social security reforms, and safety regulations were begun to be discussed seriously.

The first significant trend in Turkish labor market is the decrease in participation rate. The participation rate felt around 14\% between 1970 and 1995 . Moreover, this trend is valid for all age groups and both for males and females. There is also a large gap between male and female participation rates. The most common reasons of non-participation are being housewife, student, or disabled. The unemployment rate is stabilized around $8 \%$ in 1990s; it is well below the average of EU that is approximately $11 \%$ in 1996 (EUROSTAT, 1997b: 304). Although the male unemployment rate is generally less than the female unemployment rate, the difference is not large and even in some periods it is higher then the female uncmployment rate. The problem is that youth unemployment rate is relatively high. Another chronic problem of Turkish unemployment rates is its long-term nature. In 1995, more than $40 \%$ of unemployed had been looking for a job more than one year. It is also seen that the potential for vacancy creation is limited and follows a stable path. This may cause unemployment-vacancy gap to open up during crises.

In the last two decades, the employment share of manufacturing industry slightly increased. On the other hand, total number of workers in manufacturing industry nearly doubled in the same period. The real hourly wages are very sensitive to political factors. The wage restraint created by the legal obstacles on union bargaining after the military intervention of 1980 causes real wages to fall significantly. Another political factor is seen just before the elections. Workers in the public manufacturing industry were given high real wage increases in the pre-election periods and this trend is imitated by the private sector in some extent (Erdil, 1997). Finally, there are large inter-industry wage differentials in the manufacturing industry (Erdil, 1996a).

The military intervention of 1980 was damaged the Turkish labor movement seriously. In the following years, a very restrictive legal environment on unions and union bargaining was created by the new constitution and other legal documents. However, after 1984 we observe an increase in the union membership as opposed to 
world-wide trend but the power of unions in terms of membership is still less than the pre-1980 period. On the other hand, employers' power in both wage determination process and formulation of broad economic policies increased after 1980 considerably.

In the legal framework after 1980, the aim of controlling the collective labor movement is realized by the enactment of series of legislation towards a more central union structure. Not only the collective rights but also the individual rights of workers were hampered by the new legislation.

In conclusion, Turkish labor market with its very dynamic history can be treated as a laboratory for any type of analysis. It is also a relevant example in the context of wage leadership model. 


\section{APPENDIX 3: THE CHRONOLOGY OF TURKISH TRADE UNION MOVEMENT}

1865 First recorded protective regulation concerning employment conditions of workers in the Ereğli-Zonguldak coal-mining region.

1869 Supplementary regulations abolishing forced labor in the mines.

1872-80 Series of strikes by telegraph employees, dockworkers, and other worker groups, mainly in Istanbul.

1876 First constitution. Establishment of a parliament with limited powers.

Promulgation of the Mecelle Code, a comprehensive set of regulations combining the tenets of Islamic law with Westem legal principles.

1878 Abolition of the parliament by the sultan.

1906 Strike at the French-operated cigarette factory, the Regie.

1908 Second constitution, instigated by the Young Turks Movement, recognizes the right of association.

Series of strikes, mainly against the foreign operated companies in the major cities of the Ottoman Empire.

1909 Work-Stoppages Act bans union organizing and strikes in the public service.

1910 Establishment of the Ottoman Socialist Party by Hüseyin Hilmi, with the aim of winning the support of workers.

1914-18 The Ottoman Empire, as an ally of Germany in World War I, shares in Germany's defeat.

1919 Establishment of the Socialist Party of Turkey and the Workers' and Farmers' Socialist Party of Turkey; both seek to appeal to the workers.

1919-22 War for independence under the leadership of Mustafa Kemal Atatürk.

1920 Turkish Communist Party (TKP) founded.

1923 February. İzmir Economic Congress formulates national economic policies for Turkey.

September. Official founding of the Republican People's Party (RPP).

October. Republican regime proclaimed.

1924 First constitution of the Republic of Turkey.

1925 Restoration of Peace Act empowers the government to close down associations to facilitate the launching of Atatürk's reforms. 
1926 Civil Code, modeled on the Swiss, includes an Obligations Act dealing with the labor contract.

1932 Turkey joins the International Labor Organization.

1936 First comprehensive Labor Act. Dealing mainly with the individual employment contract of manual workers, it establishes a full-fledged compulsory arbitration system but does not permit union organizing or strikes.

1938 Associations Act Restricts the formation of associations based on religion, race, or class.

1939-45 Turkey maintains neutrality during World War II.

1946 Turkey amends the 1938 Associations Act, adopts the multiparty system, establishes a Ministry of Labor, and founds a Workers' Insurance Organization.

1947 Trade Unions Act No.5018 entitles manual workers to organize and join unions.

1950 Labor Courts established to deal with rights disputes. Following national elections in May, an RPP government takes over after ten years of Democratic Party rule.

1952 Confederation of Turkish Trade Unions (Türk-İs) founded.

1960 Democratic Party era ended by military intervention on May 27. Constitutional Assembly established.

1961 Second constitution of the Republic of Turkey, containing progressive provisions including trade union freedoms and the right to strike. Founding to the Turkish Labor party (TIP).

1962 Confederation of Turkish Employers' Unions (TISK) established.

1963 Trade Unions Act and Collective Agreements, Strikes and Lockouts Act guarantee union freedoms for both manual and white-collar workers and mark the beginning of a liberal era.

1966 RPP adopts a left -of-center platform, reinforced by policy statements in 1970 and 1974.

1968 Türk-İs adopts the "Twenty-four Principles," which embody social and economic reforms and basic right of workers.

1971 Birth of the Social Democratic faction within Türk-İş. Labor Code of 1936 amended to include both manual and white-collar workers, and to expand scope of protection. 
1977 May Day demonstration in Istanbul, organized by the Confederation of Reformist Trade Unions (DISK), leads to death of thirty-six.

1977-80 Many strikes in major industries, coupled with escalating violence of left and right extremists.

1980 Military intervention on September 12 brings a five-member National Security Council to power and establishes a Consultative Assembly.

1982 Third constitution proclaimed.

1983 May. Trade Unions Act (no.2821) and Collective Agreements, Strikes, and Lockouts Act (no.2822).

November. Free elections bring the Motherland Party (ANAP) to power.

1988 May Day demonstration to commemorate the 1977 May Day incident blocked by the police; eighty arrested.

Merger of the Turkish Communist Party (TKP) with the Turkish Labor Party (TIP) leads to the formation of a new party, the United Turkish Communist Party (TBKP).

1989-91 Frequent strikes. Türk-İs increasingly active in coordinating public sector bargaining.

1991 May. Tripartite summit meeting of employers, unions, and government seeks to establish a top-level Labor Council to improve chances for harmonious labor relations.

July 23. Constitutional Court rules to disband the TBKP, declaring it unconstitutional because it seeks to establish the supremacy of a single class and threatens to destroy the "indivisible integrity of the nation and the State". October 20. Motherland Party (ANAP) loses elections and is replaced by a coalition of Social Democratic Populist Party (SHP) and the True Path Party (DYP).

Hopes of workers raised by the new government.

1992 Moves by the coalition government to draft new legislation on job security, unemployment insurance, labor relations, and civil servants' unions arouse a great deal of controversy.

1993 An amendment both in the constitution and labor law.

1994 Turkey ratifies some ILO conventions.

1993-96 Frequent demonstrations of civil servants. 
1996 Following elections in 1995, the religious Welfare Party (RP) and True Path Partyt (DYP) form a coalition government.

1997 National Security Council dictated the resolution of Welfare Party (RP) and True Path Party (DYP) coalition.

1997 Democratic Leff Party (DSP) and Motherland Party (ANAP) formed a coalition.

1998 Constitutional Court rules to disband the Welfare Party (RP), declaring it unconstitutional because its activities is against secular character of the republic and threatens to destroy the "indivisible integrity of the nation and the State". The members of RP established a new religious party.

The leader of the Labor Party (IP) was judged and imprisoned because of his speeches.

1999 The rise of nationalist right and left wing elements in the genaral elections.

Source: Campbell (1992:587-89). 


\section{Different Labor Markets?}

\subsection{A Comparative Perspective on the Dutch and Turkish Industrial Relations Systems}

The Dutch economic system is based on values of stability and security. The Netherlands is a country with a high insurance density and is not the place where riskloving individuals constantly change relationships in order to maximize short- term profits (Groenewegen, 1998). Institutional changes are based on self-regulation since optimal use is made of diffused information and actors involved are becoming as parts of the process and this makes them responsible for the implementation. In this process, agents have a well-defined place. Visser and Heemerijck (1997) noted that Accord of Wassenaar in 1982 between the largest labor unions and the employers' associations is seemed to be a major step forward. The agreement that consists of proposals for the negotiation of wages and employment represents a change in the attitudes of both labor and employers. Trade unions were aware of the fact that wages should be frozen and employers revised their insistence on the reduction in labor time. There are three interrelated elements: wage moderation, a reduction of working time and a reduction of the government deficits (Groenewegen, 1998). Trade unions, employers and government realized that these elements should somewhat be coordinated in order to solve severe economic problems experienced at the beginning of the 1980s. This concensus and interdependence are inevitable for reaching the objectives of these agents. It was the existing institutional structure of consultation and the past experience of its usefulness that made possible to guide the process of bricolage in a specific direction (Groenewegen, 1998). The corporatist system in the Netherlands is essentially a system of voluntary arbitration, voluntary both ex ante and ex post: there is no compulsion to give up rights to the corporatist organizations, there are always escapes from the outcome (Voskamp, 1994)

Teulings and Hartog (1998:286) enumarate the paradoxes inherent in the Dutch system of labor relations:

- The economy-wide membership rate is 24 per cent, while 72 per cent of the workers are covered by collective agreements negotiated by unions. What provides unions this large leverage? 
- Anybody is free to form a union and employers can negotiate with anybody they want. Then, why is the organizational structure of unions so stable? Moreover, why do firms not negotiate with newly formed unions time and again, in particular when the existing unions have such low membership rates?

The main force behind these paradoxes lies in the system of mandatory extension. This system is also responsible for low membership rates. When a worker covered by a union contract by a legal requirement, workers have little interest in becoming members and there is a large scope for free-rider behaviour (Teulings and Hartog, 1998).

The industrial relations system in Turkey was not established on democratic grounds as in the case of the Netherlands. The dominant form is the state-directed bargaining and coercive institutions. Moreover, unlike the Netherlands, the industrial relations system was characterized by conflict at each and every stage rather than consensus. In fact, the conflict between the state and workers are more prevalent than the conflict between the capitalists and workers. The result is the some sort of the state-directed societal corporatism. When Turkish societal corporatism is compared and contrasted with Western European experiences, it seemed to be unusual since it emerged in an environment where advanced capitalist development and strong pluralist traditions were not existing (Cizre, 1984). Neither underdevelopment nor institutional drawbacks may be regarded as an obstacle for the state to create a more centralized system of corporatist bargaining. This framework encouraged a bargaining process in which the state retained an unusually high degree of independence from group demands and in which the representatives of different economic sectors rarely arrived at mutually satisfactory agreements through unmediated negotiation (Bianchi, 1984:378).

\subsection{Comparing the Facts and Figures on Labor Markets}

One of the most significant and recent changes is seen as the increasing labor force participation in the Dutch labor market and the main stimuli comes from the increasing participation of female labor force. On the other hand, Turkish labor market is characterized by an uninterrupted decline in participation rates. The main cause of this decline is drastic decline in male participation rates whereas the female participation rate is more or less stable. However, Turkish female labor force 
participation rate is almost half of the Dutch one. Moreover, there is also considerable difference between these two countries in terms of the reasons in non-participation. In the Dutch case, the most important reason is retirement while this is the fourth critical reason in the Turkish case. In Turkey, 75 per cent of the labor force is not participating since they are either students or housewife but it is around 45 per cent in the Netherlands.

Another distinctive feature of the Dutch labor market is the extremely high share of part-time employment. Almost one third of Dutch working population is employed on part-time basis. Again the main motivation comes from the females $(60$ per cent). In Turkey, around one fourth of working population is working in part-time jobs and it reaches to this figure in the last decade.

In both countries, unemployment became a chronic problem during the second half of 1970s and this situation persists until mid 1980s. However, the policies curing unemployment is notably different. In the Netherlands, by conscious policies directed towards the labor market like increasing share of part-time employment, flexible working time arrangements, and ALMPs. In Turkey, it is not possible to observe special policy proposals targeting labor market in general and unemployment in particular. Unemployment problem is somewhat cured by the side effects of more broad macroeconomic policies, especially until the mid 1990s. Export-led growth strategies combined with specific incentives for exports and investments caused an increase in demand or labor. Only in the second half of the 1990s, ALMPs were started to be discussed and they are mainly related with education and training. As another distinctive feature of unemployment in both countries is that the gap between male and female unemployment rates is wider in the Netherlands than in Turkey. . What is similar in two countries is the concentration of unemployment in younger age groups. The Dutch unemployment has a more dominant long-term characteristic. The ratio of unemployed more than 6 months is around 80 per cent in the Netherlands whereas it is around 65 per cent in Turkey. As a final point for unemployment, we observe widening of the gap between unemployment and vacancies in the last decade in the Netherlands yet in Turkey this gap is decreasing constantly after 1988.

In terms of employment shares of industries, we observe a stable decline in the share of manufacturing employment in the Netherlands in favour of services sector. However, in Turkish case the share of agriculture is decreasing in favor of both manufacturing and services sector. 
Finally, as a last point of comparison, it is noticed that wages in Turkish manufacturing industry is relatively more dispersed across sectors than in the Dutch manufacturing industry. Real hourly wages shows a stable increasing trend in the Dutch manufacturing yet it is more volatile in Turkey as we perceive frequent fluctuations.

\subsection{Routes to Wage Spillovers}

The answer to question "What is the relevancy of wage leadership model with these countries?" is hidden in the transition processes from centralized to decentralized wage determination. The institutional role played by the centralized infrastructure is thought to be replaced by other institutional mechanisms during the transition from centralized wage determination to a more decentralized one. One of these institutional mechanisms is the wage leading-following behavior among the industries. In both countries, it is observed that some collective bargains in critical industries are treated as an anchor in setting macro annual wage targets since these bargains are followed by others and in turn determine the annual rate of wage inflation. $^{20}$

However, as I will explain in chapter 6, we are neither in a position to give an over weight to institutional mechanisms nor ignorant about the relevancy of market mechanisms. Productivity, labor market tightness, alternative wage set, or price expectations may be as important as other institutional mechanisms. What we claim in this study is that the role of institutional mechanisms should not be ignored in the wage inflation process. For instance, the unemployment rate is volatile against economic crises and we have seen major upturns and downturns for both countries and as will be explained in chapter 6 we expect a strong relation between unemployment and wage inflation. Moreover, there are also significant inter-industry productivity differences among sectors both in the Netherlands and Turkey when the data is examined. This situation may well cause differences in the wage inflation rates.

\footnotetext{
${ }^{20}$ For a detailed discussion of this issue, see Visser and Hemerijck (1997) and Erdil (1997).
} 
The last question we are searching for an answer is the factors behind the institutional wage determination process. In this study, we determine two of such factors, unionization and product market structure. In the Netherlands, we have observed a declining trend in the net growth of union membership during 1980s. However, this trend is reversed in 1990s and the union policies toward more efficient structure seemed to find a considerable support. Opinion research shows a relatively high and stable approval rate of Dutch unions, their policies and leaders and three out of four workers support the view that unions are necessary institutions for the protection of collective employee interests (Visser and Hemericjk,1997:85). In the post-1980 period, Turkish trade unions have never reached their social and political effectiveness achieved especially in the late 1970s. This caused not only by the legal restrictions enacted during the military intervention of 1980 but also the lack of union policies against the changing employer profile. Nowadays, the employers follow more populist strategies and draw a profile of defending the democratic and social rights of workers more than state does. This will cause a fall in membership rates in the near future. Turkish trade unions still unaware the dangers of such a situation and inactive to formulate counteracting strategies. However, they are still powerful in the manufacturing wage determination process in some extent.

In terms of the product market structure, there is a tendency toward monopolization in manufacturing industries of both countries when we analyze fourfirm concentration ratios. In the Netherlands, for 18 out of 26 industries, the concentration ratio is more than $35 \%$. In Turkey, this is valid for 10 out 29 industries. The assumption is that the wage changes first appear in the concentrated sectors and may be transferred from these sectors to the following sectors. Therefore, the tendency of monopolization of product markets both in the Netherlands and Turkey cannot be ignored in such a study of wage inflation.

In sum, this part of the study presents the picture of labor markets, manufacturing industries, institutions in labor markets and legal framework of industrial relations in both countries. This picture will give invaluable evidences in interpreting the results of wage inflation models and formulating the policy implications of these models. 


\subsection{Concluding Remarks}

In conclusion, Dutch and Turkish labor markets have special characteristics and most of them are very differentiated but what is common in both countries is the significant experience of centralized wage determination process. In the Dutch case, it was reached through a social consensus of agents in the labor market to recover the economic difficulties of war and legislation was enacted by this consensus. Moreover, there is a mild transition from centralized to decentralized wage determination process beginning in 1960s. What is different in Turkish case is the existence of centralized wage determination process forced on the agents by the state. Legislation is very restrictive on rights of agents and even against the will of these agents in the labor market. Furthermore, the transition is more unstable. From centralized wage determination process to decentralized one by the military intervention of 1960 and once again a more centralized structure brought by the military intervention of 1980 . In the late 1980s, there is again a tendency towards decentralized structure and less restrictive legal environment. 


\section{PART II: THEORIES AND FANTASIES ON WAGE SPILLOVERS}

Part II consists of chapters 5 and 6. In Chapter 5, first a brief analysis of orthodox theory of wage inflation will be presented in the context of a conventional bargaining model and second a historical outlook to the development of a theory of wage inflation emphasising the relevance of institutional factors will be discussed. In chapter 6, after an anlysis of the properties of the bargaining models, two variants of bargaining models of wage inflation will be formulated in the light of the models discussed in chapter 5. First, a typical bargaining model of wage inflation is presented. Second, a wage leadership formulation as a representative version of spillover models of wage inflation is derived. 


\section{WAGE SPILLOVER IN RETROSPECT}

\subsection{Introduction}

Throughout the postwar period, it is possible to observe a substantial dichotomy amongst economists in terms of the relative importance of market and spillover forces in transmitting inflationary impulses across the labor market. As it has already been stated this dichotomy can be observed at the first sight but it is not as sharp as generally thought. The spillover approach to the labor market is nothing but an extension of the market model. Many economists, as adherents of orthodox view, claim that market forces largely determine both the structure of relative wages and the dynamics of the general wage level. However, institutionalists deny that the dynamics of the modern institutionalised labor markets can be explained in terms of this orthodox vision and support the idea that the process of wage adjustment can be understood in terms of social, political and institutional forces.

As a result of this survey of the literature, we will conclude that the instutionalist model established a solid theoretical basis for their analysis not only by using tools and postulates of orthodox market models but also by recognizing the relative importance of institutional factors in the wage determination process. Therefore, the two most consistent models of spillover, the threat effect and wage leadership hypothesis, use the postulates of rational choice theory yet they introduce specific assumptions about the institutional environment that are partly ignored by the neoclassical analysis of wage determination. Moreover, it is clear from the survey that the spillover effects are an undeniable fact in the labor market. Different conclusions reached by different studies, however, suggest that the spillover effect is quite sensitive to the specification of the model and the time period considered.

\subsection{A Typical Bargaining Model of Wage Inflation}

Although orthodox wage theory is specified in real terms it is possible to derive a corresponding proposition in terms of nominal wages ${ }^{21}$. First, it is assumed

\footnotetext{
${ }^{21}$ For the examples of orthodox wage theory-discussed in this chapter, see Agarwala, et.al, (1972), Driehuis (1975), Addison and Burton (1978 and 1979), and Bemmels and Zaidi (1990).
} 
that all firms in any sector $i$ have the same Cobb-Douglas production function, and according to the condition of profit maximization the rate of growth of demand for labor in that sector $\left(L_{i, t}\right)$ is given by

(5.1) $L^{d} d_{i, t}=v a_{i, t}-w_{i, t}$

where $v a_{i, t}$ is the rate of growth in real value added in industry $i$, and $w_{i, t}$ is the rate of growth in real wages in industry $i$, and $t$ is a time subscript.

Moreover, it is assumed that the labor supply to any sector is a multiplicative function of its own real wages and wages in alternative sectors. Then the sectoral labor supply function can be written as

$$
L_{i, t}=\gamma_{0} w_{i, t} \gamma_{i} w_{1, t} \gamma_{1} w_{2, t} \gamma_{2} \ldots \ldots w_{n-1, t} \gamma_{n-1} w_{n, t} \gamma_{n}
$$

where $\gamma_{i}>0$ and $\gamma_{0}$ is a parameter showing the effects of all other aspects of net advantages on the labor supply decision and all these net advantages are assumed to be intertemporally invariant. $w_{a}$ is the opportunity cost of labor or alternative wage set which is the set of real wages in alternative sectors to which actual and potential $i_{i}$ th sector labor suppliers are assumed by neoclassical theory to compare $i^{\text {th }}$ sector wages in making their supply decisions or maximizing net advantages. It is possible to obtain an equation determining the rate of growth of labor supply $\left(L^{S}\right)$ to sector $i$ by taking the logarithmic time derivative of equation 5.2 .

$$
L_{i, t}=\gamma_{i} w_{i, t}+\sum_{a=1}^{n} \gamma_{a} w_{a, t}
$$

The market equilibrium growth rate of real wages $\left(w^{*}{ }_{i, t}\right)$ in sector $i$ can be determined by equating equations 5.1 and 5.3 .

$$
w_{i, t}^{*}=\alpha_{0} v a_{i, t}+\sum_{a=1}^{n} \alpha_{a} w_{a, t}
$$

where $\alpha_{0}=1 /\left(1+\gamma_{i}\right)>0$ and $\alpha_{a}=-\gamma_{a} /\left(1+\gamma_{i}\right)>0, a=1 \ldots n$

The real wage lag adjustment hypothesis can be incorporated by assuming that markets do not clear instantaneously. That is, during a given period, only a fraction $\theta_{i}$ of the difference between the equilibrium rate of growth in the $i t h$ real wage $w_{i, t}^{*}$ and the last period's actual growth rate $w_{i, t-1}$ is actually realized.

$$
w_{i, t}-w_{i, t-1}=\theta_{i}\left(w^{*}{ }_{i, t}-w_{i, t-1}\right)
$$

Substituting equation 5.4 into 5.5 gives 


$$
w_{i, t}=\varepsilon_{i}+\pi_{i} v a_{i, t}+\sum_{a=1}^{n} \phi_{a, i} w_{a, t}+\rho_{i} w_{i, t-1}
$$

where $E\left(\varepsilon_{i}\right)=0 ; \pi_{i}=\theta_{i} /\left(1+\gamma_{i}\right) \cdot\left[0<\pi_{i}<1\right] ; \phi_{a, i}=-\theta_{i} \gamma_{a} /\left(1+\gamma_{i}\right)$, and $\rho_{i}=1-\theta_{i},\left[0<\rho_{i}<1\right]$.

Then, in order to express this relation in nominal terms and assuming as in the strict neoclassical view that all agents do not have money illusion, the current expected rate of growth in the price level $\left(P^{e}\right)$ can be added to both sides of the equation (5.6). Finally, for the completeness of the analysis, the inverse of the economy-wide unemployment rate $\left(U^{-1}\right)$ which shows labor market tightness, can also be included in equation (5.6). Thus, equation (5.6) becomes

$$
W_{i, t}=\varepsilon_{i}+\pi_{i} v a_{i, t}+\sum_{a=1}^{n} \phi_{a, i} w_{a, t}+\rho_{i} w_{i, t-1}+\lambda_{i} p e_{t}+\sigma_{i} U_{t}^{-l}
$$

The above reduced form equation model is a general representation of the orthodox market model of wage inflation that can be found in the literature. As it is observed at the first instance, this model partly ignores the institutional factors in the labor market that may affect the wage inflation process.

\subsection{Spillover Models of Wage Inflation}

Some of the literature on wage determination has been concerned with wage adjustments that are linked through some sort of spillover mechanism. The main theme underlying this wage interdependence is that the wage settlements reflect not only the traditional labor and product market forces affecting a particular industry, but also the wage settlements achieved by other industries. According to institutionalists, the working of this spillover process has a different character from the traditional market process. Although it is possible to observe some conflicting views amongst the institutional economists, all of them agree that nominal changes in wages are primarily transmitted from one sector of the labor market to another not by a market mechanism but by a spillover mechanism.

Early work on wage spillover done in the 1940s was based on the concept of equity, that is equal pay for equal work. Ross (1948) emphasized the equity concept as he believed that the supply and demand in the labor market are of limited relevance for wage determination, because wages are often determined on the basis of wages in 
the other industries. This concept is based on the notion that a group of workers whose wages had fallen behind in the inter-industry wage structure would speed up their rate of wage increases.

Addison and Burton (1977) presented a comprehensive classification of the spillover hypothesis in the literature. Here, this classification will be used in reviewing the institutionalist literature on wage spillover. They classified six types of hypotheses as wage contour, relative deprivation, morale effect, union politics, threat effect, and wage leadership. All of these hypotheses will be discussed in following sections but wage leadership will be the one to be explained in detail. In addition to these six hypotheses, a separate attention will also be given to spillovers through wage bargaining.

\subsubsection{Wage Contour Hypothesis}

The wage contour hypothesis was first proposed by Dunlop (1957) in his pioneering study. He emphasized the imitative wage behavior in his description of a wage contour which consists of a group of firms whose wage determination process is linked together and wage rates in this group of firms set pattern for inter-firm wage rates. A wage contour is defined as a stable group of wage-determining units linked by the common possession of similar product of labor market characteristics, therefore they have similar wage-making characteristics (Dunlop,1957:131). According to this definition, relevance of market variables is not completely rejected. The adherents of this hypothesis do not deny the limited effect of market forces in wage determination but they argue that market forces work so slowly that they bring uncertainty associated costs (Addison and Burton,1977:339). In fact, the central assumption in wage contour hypothesis is that wages are not set by the interaction of demand and supply at least for a major portion of the labor market but that they are administered prices and settled by the workings of institutionalized markets. The boundaries of this are set by both formal and informal rules.

Hence, there is a very strong incentive for decision makers to administer wages according to extra-market criteria. Thus, many companies are secn as administering their own internal labor markets that are only loosely linked to the external market through certain jobs that fulfill the function of being ports of entry to the internal labor market (Addison and Burton,1977:339). The wage rates for these 
jobs are considered as the contact points between internal and external markets and constitute key rates. Dunlop (1957:128) concluded that these key rates lie on one or more wage contours. Other wages apart from the key rates tend to follow but there is a considerable discretion since job descriptions and contents vary. In a similar manner, the key rates are assumed to move together following the pattern set in one or more key bargains negotiated with leader firm(s).

The wage contours are seemed to be temporary, even though there is an evidence to maintain the existence of wage contours in empirical applications. Moreover, according to Addison and Burton (1977:339-40), the predictive content of the wage contour hypothesis is by no means clear. The question of determination of the key bargain is unanswered and the nature of a wage contour is misspecified. The word "similar" in the definition of wage contour does not explain which similarities are significant.

In sum, a wage contour is a stable group of wage-determining units. These units may be plants, firms, or some bargaining units. A wage contour contains one or many key settlements. The wage contour is comprised of the rates for the key wage determining unit(s). These key settlements are followed by other wage determining units. Some units are very closely related to the leader(s) and some have indirect relations. Therefore, if one moves toward the exterior of contour, the units will follow the leader(s) weakly.

\subsubsection{Relative Deprivation Hypothesis}

The concept of relative deprivation has been popularized by Runciman (1966). Relative deprivation is originated in inequalities of class, status, or power. Runciman (1966) offered a definition of this subjective magnitude and he specified three conditions for the existence of relative deprivation. First, if some individual should notice a disparity between his situation and that of the referent(s) while he makes comparisons with some group of referent(s). Second, as a result of these comparisons he should want to change his situation. Third, this change should be feasible. Baxter(1973) hypothesized that relative deprivation varies in magnitude, that is, the extent of difference between the desired and actual situation perceived by the individual, frequency which is the proportion of the membership group experiencing such insights of relative deprivation, and the degree of intensity with which such 
perceptions are experienced by the individual. According to Baxter (1973:281), wage inflation can be decreased by an egalitarian policy of income distribution since it is connected to inequalities in the social system.

Thurow (1978) hypothesized the concept of psychic income which is related to the characteristics of a job. In fact, this is a kind of non-monetary benefit of work that individuals make reference for group comparisons. According to Thurow (1978:145), this concept can help to explain many of the observed realities of labor market, including rigid relative wages and downward rigidity of money wages.

Hines (1969) presented some empirical relevance for reference group theory in his disaggregated study of U.K. wage inflation for the period 1948-62. In order to identify reference groups in wage comparisons, he correlated each industry's annual wage change with lagged annual wage change of other industries and selected the industries with highest correlation coefficient as reference groups. By applying the same methodology for a different sample period, Sargan (1971) found almost completely different results.

Brown and Sisson (1975) tried to find out the role of reference groups in wage determination but instead of using the industry level data they used workplace comparisons. They found support through an analysis of variance of wage changes in two samples of Fleet Street newspaper offices and Coventry engineering industry. They observed that there had been a general tendency from the use of intraoccupational and inter-plant wage comparisons towards the use of inter-occupational and intra-plant reference group comparisons in wage determination.

McCarthy, O'Brien and Dowd (1975) attempted to identify reference group comparisons in wage determination for Ireland. They found that the craft sector was the reference sector for wage comparisons. They also claimed that bargainers in collective agreements use comparability principle more frequently as compared to economic arguments. The only economic factor that seemed to be the most important was the cost of living.

Arestis and Mariscal (1995) estimated a general model combining complementary theories of wage determination for U.K., and found that reference group wage comparisons and the relative situation of individual worker in the wage ladder plays an important role in wage determination in addition to efficiency wage, hysteresis, and income distribution models. 
One of the main problems of relative deprivation hypothesis is its speculative character in defining relative deprivation. More importantly than this, this hypothesis does not specify a mechanism by which perceptions of relative deprivation is transmitted to actual wage changes. In relation to this shortcoming, the analysis does not clearly consider the existence of socio-economic constraints on the fulfillment of desires. Moreover, the relative deprivation hypothesis does not allow quantification of the stock of relative deprivation. In consequence, the proposition that wage increases are determined by relative deprivation cannot be directly tested against reality. Researchers have employed indirect tests seeking to infer-reference group comparisons from the data on wage changes because of this difficulty. Unfortunately, such attempts to identify reference groups involve rationalization of data in terms of theory. Finally, it can be concluded that the relative deprivation hypothesis falls short of explaining a substantial mechanism of wage transmission.

Finally, the main theme behind this hypothesis can be summarized with one clause "psychological factors in wage demands". While deciding upon their wage demands, workers first determine reference group(s). These comparisons may be carried at inter-industry, intra-industry, or workplace level. The relative situation of individual worker or group of workers in the wage ladder determines the growth in wages. Such comparisons create a leading-following behavior in the wage settlements.

\subsubsection{Morale Effect Hypothesis}

The basic assumption behind the morale effect hypothesis is that labor turnover is costly to firm because of the existence of hiring and training costs and because the cost of policing employee effort is non-zero (Addison and Burton,1977:341). This morale effect hypothesis in wage determination is first proposed by Behman (1964). Behman's argument is as follows: A basic characteristic of the labor market at any time is that the economy is in inherent regularity and the desire for regularity affects the decisions of both employers and workers. From the firm's viewpoint, an efficient work force is an essential condition for a profitable operation. The firm benefits if it can keep its regular complement of workers, especially the permanent employment of workers in requiring responsibility or a skill acquired over a period of years is advantageous for the firm. Therefore, the firm is 
motivated to keep labor turnover at a minimum level. From the worker's viewpoint, job stability provides various benefits. If he gets established in a satisfactory job, he can live in a place convenient to his work. If he were to quit, then he could expect to subject significant costs. If he is a semi-skilled worker, loss of his job might mean starting in a lower occupational level on his next job. Moreover, a permanent service with the same employer gives the worker some measure of security, his seniority may be sufficient to protect him from most layoffs since at times of crisis firms prefer to layoff less senior workers. He may also have accrued certain pension rights because of his seniority. Therefore, there is a desire for regularity on both worker's and firm's side.

This behavior implies for the wage determination that existing wage levels can withstand minor fluctuations in supply and demand but when pressure passes a certain level wages are altered. Suppose the demand for the product of a particular class of labor increases. At the first instance, this new demand is probably concentrated in few firms. If this change in demand is temporary, less adjustment is required than if the change is expected to be permanent. For the temporary case, firm may use overtime or transmit the orders to other firms. If the increase in product demand is permanent, overtime and loss of orders become costly to the firms. Under these circumstances, firms try to hire specific labor that meets their hiring criteria. If this increase in demand for qualified labor is met from the pool of unemployed, there will be no reason to increase money wage rates. However, if this pool is not enough for the expanding firm, it tends to offer higher wage rates. Once wage increases have been triggered in a sector experiencing increasing product demand, then the increase in money wage rates is diffused throughout the industry. A gradual flow of labor is observed from the less active to more active centers. But before a worker moves to seek work on better terms offered elsewhere, it is reasonable for him to try and get better terms from his present employer.

Hence, prosperous firms that do noi want to lose qualified and trained workers give the wage increases not only to the workers who really move but also to the other workers. If the wage increases were not generalized, those workers who would not move would be likely to express their resentment in reduced efficiency and this raises labor cost per unit to the firm. Thus, the money wage rate increase in one sector is transmitted throughout industry by the moralc effect. 
Behman (1964) has tested for an association between the rate of wage inflation and labor turnover variables in aggregate U.S. manufacturing in the period 19461961. It is found that quit rate explained $90 \%$ of the movement in the rate of change in hourly earnings. The major finding of this study can be considered as the introduction of quit rate as a behavioral variable explaining the rate of wage changes and spillover effects. However, it is not possible to treat this study as a major benchmark against neoclassical market model since the concepts used are usually utilized by the neoclassical model and union behavior seemed to have a secondary importance in the study.

In another study of job satisfaction, Borjas (1979) provided a systematic empirical analysis of the effect of union membership on job satisfaction and wages and showed how the interaction between these effects leads to empirically observable relations between unionization and individual quit probabilities. The major empirical finding is that union members report significantly lower levels of job satisfaction on average. It was also found that the union effect on job satisfaction was highly dependent on job tenure. In this study, unions are seen as the main transmitting force of wage changes as a result of increasing job satisfaction. In this respect, his study can be treated as more consistent as compared to Behman's study.

In conclusion, morale effect hypothesis leads on the premise that both workers and firms have a strong desire for regularity in the labor market. Firms want to keep the labor turnover costs as low as possible and have a tendency to minimize these costs. On the other hand, workers also prefer to stay at the same job mainly because of the benefits provided by the seniority. Wage levels resemble minor fluctuations in response to mild changes in supply and demand. However, there is a threshold level at which workers may demand increases in wages. The large and monopolistic firms give wage increases especially to qualified workers and these wage increases first spillover in the firm and then followed by other firms. Therefore, the wage increases spillover throughout the sectors of the ecoriomy.

\subsubsection{Union Politics Hypothesis}

The union politics hypothesis is first discussed by Ross (1948). In this hypothesis, it is assumed that union leaders are concerned to maintain the size, survival and growth of the organization that they lead and upon which their status 
rests. Moreover, they are also interested in the maintenance of their continued tenure in office. All of these concems cause union leaders to try to follow wage increases imposed by other unions. Otherwise, their status is challenged by the loss of membership and growing resentment amongst the rank and file. Hence, by the effect of union leaders with these incentives, wage increases spillover from one sector to another. Moreover, Ross (1948) assumed that this process will occur in a manner unconstrained by the employment effects of wage increases due to the difficulty of estimating the slope and position of the wage-employment tradeoff in a world of uncertainty, and the probably variable and lengthy time lags in the employment effect. In fact, Ross (1948) thought that union was a political agency acting in an economic environment and that among all the participants in economic life, the trade union was probably the least suited to purely economic analysis.

Rees (1951) observed political environment between and inside the unions as an important factor in wage determination in his study of U.S. steel industry. The rivalry between right-wing and left-wing unions seemed a bitter one in the 1940s. The prestige of leaders of the United Steel Workers which was a right-wing union would have suffered in the cyes of the membership had the left-wing United Auto Workers won substantially larger wage increases. Another observation of Rees (1951) is that pressure for inter-industry wage uniformity or at least an appearance of uniformity is generated by such rivalry and operates on the management side as well. Management recognized the role of wage settlements in maintaining the prestige of union leaders and therefore forced to include as an element of its wage policy and its own preference between the existing leaders of the unions with which it bargains and potential rivals (Rees,1951). Such factors give rise to an observable inter-industry transmission of wage settlements.

Flanagan (1976) also treated union politics as one of the reasons of similar wage changes. He stated that union leadership is presumed to gain utility from both higher wages and more employment of the membership. Moreover, for internal political reasons, unions may simply ignore market conditions in setting wage objectives, except in cases of serious threat to employment and membership. In terms of employment, his formulation is clearly opposed to Ross (1948).

Freeman (1980), on the other hand, claimed that union leadership tries to lessen the wage dispersion in order to establish union solidarity. Union solidarity is difficult to maintain if some workers are paid markedly less than others, and such a 
pattern invites division within the organization and loss of certain common advantages such as joint strike funds and interrelated policies toward major employers. Union solidarity in major issues causes leaders to be more powerful. Freeman (1980), in fact, explained not only the spillover of wages from one sector to another but also the spillover of collective behavior.

In conclusion, while the union politics hypothesis provides clear mechanism whereby relative deprivation feelings induced by wage increases outside of the membership group generate forces that wifl lead to the matching of the external wage changes, it is not satisfactory as a theory of wage inflation in that the general rate of wage inflation in the unionized sector of the labor maiket is indeterminate, as all spillover coefficients are unity in value and the wage inflation process is unconstrained by the demand side of the labor market (Addison and Burton, 1977:341). The last point is especially observed in the hypothesis proposed by Ross (1948). Moreover, the union politics hypothesis does not explicitly generate any predictions about the behavior of money wage change in the non-union sector. Finally, this hypothesis is not verified by the econometric methods in the literature.

Union politics hypothesis summarizes the political elements between and inside the unions in the wage determination process. Union leaders mainly follow the wage increases imposed by other unions in order to be politically strong, not to loose members, and more importantly to increase membership. Moreover, decrease in wage dispersion between union members supports the union solidarity. This behavior, therefore, causes wage increases to spillover from one sector to another.

\subsubsection{Threat Effect Hypothesis}

The threat effect hypothesis is a hypothesis of spillover from union to nonunion sector. The threat effect hypothesis analyzes the labor market in two sectors, the unionized and the non-unionized sectors, and it basically postulates that wage increases in the union sector cause employers in the non-union sector to increase wages because of the threat of unionization in this sector. Slichter (1954) argued that changes in union wages have a direct and positive spillover effect on non-union wages as non-union employers reacted to an increase in union wages by raising their wage offers in order to reduce the threat of unionization of their work force that was posed by the initial increase in union/non-union wage ratio. 
The threat effect hypothesis was first tested by Rosen (1969) for U.S. manufacturing industry and his model predicted that an increase in union power would cause an increase in non-tinion wages. The non-union response occurs because non-union employers calculate that non-union workers are less likely to unionize when the non-union firms are independently responding to union wage increases. Rosen (1969) introduced a probability structure in his estimating equation and assumed that profit-maximizing non-union employers will set the wage rate so as to minimize the expected wage rate that they would face. After he controlled individual characteristics, Rosen (1969:189) used three different levels of probability of increase in union power $\left(D_{i}\right)$ in estimating his wage equation; $D_{i} \leq 0.5,0.5<D_{i} \leq 0.8$, and $D_{i}>0.8$. His results suggested larger threats at lower levels of unionization in concentrated industries. It is well known that concentrated industries have generally been the most resistant to unionization. It could also be true that nonorganized firms in concentrated industries tend to buy more protection against unionization by greater threat and indirect responses. Moreover, Rosen (1969:193-94) drawn a threatcoverage function which is negatively sloped at high levels of unionization. This means that threats of further organization fall at high levels of unionization. When mean unionization rate of an industry is high, remaining non-union firms were the original holdouts and hardest to unionize to begin with and their threat responses were lower than subsequently unionized firms (Rosen, 1969:194-95).

Before Rosen (1969) the generally accepted reason of unions ability to increase wages is that that when they are first organized they are more successful but, in the course of time, their ability to increase wages decreases because of the increasing substitution over the long run. But Rosen (1969:195-96) concluded that the union's ability to raise wages depends on threat responses of non-union firms. If threats are high, the result will be both higher union and non-union wages. Non-union firms' evaluation of threat is a highly subjective matter and will be far less certain and more likely to change when there is a short story of unionism in the industry rather than a long one.

Ashenfelter, Johnson, and Pencavel (1972) examined a model of wage determination in the union and non-union sectors of U.S. manufacturing industry in order to obtain effects of trade unions on the rate of change of average money wages. They first found that the presence of unionism affects the form and timing of money 
wage changes. Their estimated equation also suggested that the presence of unionism eliminated the short-run response of union wage changes to market forces. Finally, their results were consistent with the hypothesis of significant spillover effects of union wages on non-union wages through the threat effects.

Schmidt and Strauss (1976) analyzed effect of unions on earnings and earnings on unions and, as opposed to most of the union studies, they treated unionism as an endogenous variable to the model in a mixed logit approach for U.S. manufacturing industry. According to them, unions cause wages to increase through threat effects but wages also have an effect on the extent of unionization since relative wages affect the attractiveness of various industries to a potential union organizer. Therefore, this implies that extent of unionization would more properly be viewed as jointly or simultaneously determined with wages rather than being treated as exogenous. Their hypothesis is verified by the empirical application and they found out that union membership has a positive effect on earnings and earnings have also a positive effect on the probability of union membership.

Mitchell (1978), in his study of union wage determination in U.S. manufacturing, claimed that non-union employers will make their wage decisions according to the behavior of the labor market in the absence of legal constraints and threat effects of potential union organization. He found that the wage determination in the non-union sector is more sensitive to real business conditions although he did not completely reject the role of threat effect in the non-union wage determination.

Kahn (1980), in his study investigating the effect of unionism on the real wages of non-union workers in U.S. economy, asserted that the union impact on nonunion workers' real wages is made up of opposing forces and is a priori ambiguous. On the one hand, unions may indirectly cause the crowding of workers into non-union jobs, lowering wages there. On the other hand, union threat effects may cause nonunion employers to raise wages. Kahn (1980:97) claimed that these influences may vary according to demographic group and his results had implications for labor market segmentation. He found that a rise in union wages causes an increase in the wages of non-union white males via threat effect but has a crowding effect for the non-union female and non-white workers by lowering their wages.

Freeman and Medoff (1981) carried out a study for production workers in U.S. manufacturing to test the impact of the percent organized on union and non-union wages. The major finding of their research is that the percentage organized has a 
strong positive association with the wages of union production workers but has either no association or a weak positive association with the wages of non-union workers. As a result, they claimed that the union/non-union wage differential is positively related to the extent of organization.

Oswald (1981) examined threat and morale effects as the transmitting forces of wage changes from union to non-union sectors in a general equilibrium setting. According to him, the productivity of non-union workers is assumed to depend on their own wage and the wage rate being paid to workers in the unionized sector. Oswald (1981:270) blamed conventional theories of morale and threat effects as being incomplete since they treated the problem in a partial equilibrium setting and the nature of threat and morale effects was ad hoc in these studies. His argument is as follows: A rise in union wage rate makes non-union workers less productive through the morale effect and this reduces the value of workers' marginal product and tends to lower the demand for non-union workers. A rise in the union wage rate raises the expected wage of a non-union employer through the threat effect and this reduces the demand for non-union labor because firms equate the expected wage rate with the value of the marginal product of non-union workers. Finally, a rise in the union wage rate increases the supply of non-union labor by displacing workers from the unionized sector. However, Oswald (1981) misinterpreted the point that subjective valuation of employers about their change in demand for non-union employer depends on the relative magnitude of the rise in expected wages of non-union employers and the potential rise in non-union wages through increasing extent of organization.

Moore, Newman and Cunningham (1985) asserted that the effect of the extent of unionism on the wages of non-union workers is composed of conflicting forces and is theoretically indeterminate. They listed three forces at work, namely, crowding, demand, and threat effects. While the first has a negative effect on non-union wages, the last two have positive effects. In the crowding effect, a rise in union wages would cause a fall in demand for labor in union sector, producing an excess supply of labor in the non-union sector that tends to lower wages in non-union sector. However, the relatively high skill levels of union workers are neglected in crowding explanation and the perfect substitution between union and non-union workers is open to discussion. The demand effect suggests that increases in union wages will increase the cost of production in the union sector, resulting in a higher demand for the products of non-union firms and a higher demand for non-union labor with increased wages for 
them. In the threat effect, non-union employers raise wages to prevent the possibility of union organization within their own firms. Moore, et.al. (1985:31-41) tested the significance of these effects in U.S. economy for the period 1973-1979 and found a considerable evidence to suggest that increases in the extent of unionism and union wages in an industry have substantial positive effects on the wages of non-union workers.

Podgursky (1986) analyzed the threat effect in terms of different sizes of employers for the private sector production workers in the U.S. His study showed that coverage of workers by a union contract and strength of unionization in their industry have sharply different wage effects in establishments of different size. The results of Podgursky (1986:284) suggest that large non-union employers tend to match the union wage levels at all levels of unionism in their industry; medium-size non-union employers match the union wage increases only as the union presence in their industry appear to be large; and small non-union employers maintain wages below the union rate at all levels of union organization of their industry. This study is really interesting in separating the threat effects of non-union wage increases in terms of employer sizes and its findings are consistent with the hypothesis that for any given level of industry organization, large establishments, as more attractive organizing targets, are more likely than small establishments to raise wages in order to avoid unionization.

Dickens (1986) proposed that non-union employers pay above market-clearing wages to deter unionization and the determinants of the wage that a non-union employer must pay to avoid unionization are the magnitude of supra-competitive rents and the costs of organizing. Dickens and Katz (1987) conducted an empirical analysis of the union threat explanation of non-union industry wages. They found that that the sign of the percent unionized variable in the non-union wage regressions is generally positive but they pointed out that the hypothesis is only weakly supported because the coefficient is not always positive and is often statistically insignificant. Some of the other variables support the threat model, particularly the positive coefficient on profitability which they indicate supports the hypothesis that the higher potential rents, the higher the wage.

Neumark and Wachter (1992) tested threat, crowding, and complement models for U.S. economy by using a panel data set. The first two models were explained previously and the logic is same in their analysis. In the complement model, 
there are three sectors: a union sector, a substitute non-union sector that competes with the union sector, and a complement non-union sector that serves as a production complement to both the union and substitute non-union sectors (Neumark and Wachter,1992:7-11). Workers in the complements sector may include non-union workers employed in the same establishments as union workers, or non-union workers in non-union firms that act as suppliers to the union and substitute non-union sectors. Lower union sector output would thus reduce the demand for non-union complement workers, and reduce their wages and employment. The results found the complement model to be more consistent although some weaker evidence is obtained for the threat hypothesis.

In another study with a different data set, Neumark and Wachter (1995) tested threat and crowding effects of unions on non-union wages at the industry and city levels across occupations. Their results suggested that at the industry level crowding effect dominates threat effect while at the city level threat effect explains non-union wage changes. Moreover, their results supported the threat effect in the white-collar and management and professional market, and the crowding effect in the blue-collar market.

In conclusion, the threat effect hypothesis constitutes one of the most acceptable basis for spillover theories of wage inflation. As compared to union politics hypothesis, it is more satisfying since it provides a determinate model of spillover wage inflation that contains the behavior of union and non-union sectors of the labor market and which does not ignore the impact of potential employment effects on the determination of union wage policy.

Threat effect hypothesis summarizes the wage spillover from union to nonunion sector. Employers inherently do not prefer a strong union movement in their firms. In order to prevent this danger for unionization, wage increases in the union sector is followed by the non-union sector. Increase in union power in the union sector causes increase in both union and non-union wages. Thus, wage increases in the union sector spillover to non-union sector.

\subsubsection{Spillovers Through Wage Bargaining}

In this section of the study, although we will discuss the wage bargaining models in general, the Scandinavian models of wage bargaining will be analyzed in 
more detail since these models contain significant insights in terms of the impacts of institutional factors in wage setting that we utilize in this study. In this context, we also analyze the concept of wage drift. First, we will discuss some general characteristics of bargaining process. Second, we will present the one of the simplest but the oldest model of wage bargaining proposed by Hicks (1966). ${ }^{22}$ Third, the exchange theory of Kuhn (1974) will be presented. Fourth, basic points of the behavioral theory of Walton and McKersie (1991) will be analyzed. Fifth, the models from the LSE (London School of Economics) tradition will be put forward. Sixth, the Scandinavian models of wage bargaining will be discussed. Finally, facts and characteristics of bargaining process in Scandinavian countries will be analyzed. ${ }^{23}$

Bargaining strength has both a subjective and objective element (Elliott, 1991:363). Workers' bargaining strength subjectively depends on the firm's assessment of their willingness to withdraw their labor. This largely depends on the degree of harmony that typifies industrial relations in the firm. Bargaining strength objectively relies on the magnitude of the costs one party can impose on other. Workers may have bargaining strength if they are able to reduce the firm's output and thus causes a fall in firm's profits by withdrawing their labor. The level of this power is determined by the elasticity of substitution and by the elasticity of supply of substitute factors of production. Bargaining power is also depend on the elasticity of demand for the output. Bargaining may not emerge simply because the total benefits from bargaining are less than the total costs obtained from it. In order to reduce the costs of bargaining Williamson et al. (1975) proposed that parties will observe particular conventions or rules of behavior. Informal and unwritten rules of behavior alleviate the excessive costs of continual bargaining and remove the uncertainty that would otherwise characterize these situations. A distinctive characteristic of the internal labor market is that rules are very often substituted for market processes. Comparability, the objective of securing a wage growth, analogous to that of similar workers elsewhere, may highlight significantly the rules that determine wages. Consequently, the wage rates of various groups in the internal market may be linked together by custom in what have been called job clusters (Dunlop, 1957:16). The

\footnotetext{
${ }^{22}$ Hicks originally proposed the theory in 1932 .

${ }^{23}$ For a detailed discussion of bargaining models, see Oswald (1985), Pencavel (1985), and Booth (1995).
} 
wage rates of each occupation within the cluster are tied to a key rate and this key rate is linked to that of others. The key rates generally constitute ports of entry to the internal market and thus they provide linkages to the external market (ibid., 17-20). Movements in these key rates are the main determinants of changes in internal wage structure of the firm.

What is common for all bargaining processes is the use of threats by the two parties. Specifically, strikes, or the threat of a strike are outstanding characteristics of the collective bargaining process in numerous cases. The ways of behaving of each party through the wage bargaining are determined by what each perceives to be the costs of agreeing to the other party's wage offer, weighed against the costs perceived to be attached to the party's disagreeing to the offer (Elliott, 1991). Elliot (1991:423) identify each party's bargaining attitude by the balance of the costs of agreeing relative to the costs of disagreeing as follows:

$$
\begin{aligned}
& \text { The Trade Union's Bargaining Atitude }=\frac{\text { Costs of disagreeing with employer }}{\text { Costs of agreeing on employer's term }} \\
& \text { Employer's Bargaining Atritude }=\frac{\text { Costs to employer disagreeing with union }}{\text { Costs of agreeing on union's term }}
\end{aligned}
$$

These ratios mean that as long as they are less than 1 , neither the union nor the employer not be inclined to settle.

The first and may be the simplest model of wage bargaining was introduced by Hicks (1966:136-57). In this model it is supposed that the management and labor are bargaining over only one issue: the size of the wage increase to be granted. Then, the question is how the percentage increase that the union demands and the increase that the employer is willing to grant would vary with the expected duration of strike.

Hicks (1966) analyzed this question with a figure like in Figure 5.1 in which the vertical axis shows the percentage wage increase over which labor and management is bargaining. On the employer side, the firm's highest pre-strike wage offer is assumed to be $W_{f}$. If that offer is rejected and a strike arises, the employer may be able to service its customers for a relatively short period of time through accumulated inventories the use of nonstriking employers in production jobs. As a strike progresses, however, the costs of lost business or dissatisfied customers mount, and the employer can be expected to increase its wage offer in an effort to end the strike. The expected willingness of employers to increase their wage offers as strike prolongs is illustrated by the upward-sloping employer concession schedule (EC). On 
the other hand, the union is assumed originally to accept some wage increase, like $\mathrm{W}_{\mathrm{i}}$, without a strike, but after a strike commences worker attitudes may harden, and the union may essentially increase its wage demands early on. After some point during the strike, however, the loss of income workers are bearing starts to affect their attitudes, and the union will begin to revise its wage demands in the downward direction. This reduction is shown by the union resistance curve (UR).

\section{Figure 5.1: Hicks's Bargaining Model}

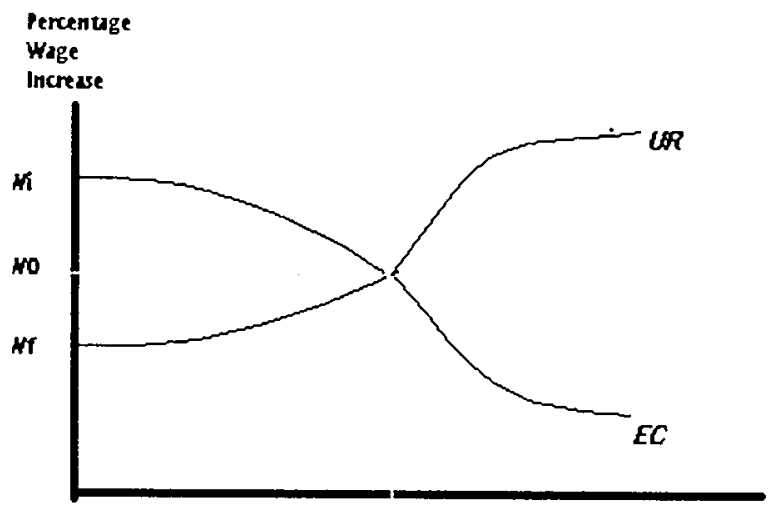

SO

Expected Strike Length (s)

Source: Hicks (1966:145).

As the strike proceeds, one expects the union's demands to decrease and the employer's offer to increase, until at strike duration $S_{0}$ the two will eventually coincide. At this point a resolution is reached on a wage increase $W_{0}$, and the strike is expected to come to an end. In fact, this simple model has several implications.

First, holding the EC schedule constant, anything that shifts the UR schedule upward that is increases union resistance to management will both lengthen the expected strike duration and raise the wage increase that can be expected. This increased resistance may be manifest in either a higher no-strike wage demand, an increase in $\mathrm{W}_{\mathrm{i}}$, or a flatter slope to the UR curve, which would indicate that the union is less willing to modify its wage demands as strike proceeds. The evidence for such a behavior of UR curve is presented by McConnell (1989) and Card (1990). Union resistance can be expected to increase, for instance, if the costs the workers of being 
on strike were to fall. More specifically, if the unemployment rate is too low that the workers on strike can easily obtain temporary jobs, or if union members are able to collect some form of unemployment benefits during the strike, then their motivation to strike or to stay on strike will increase. In fact, there is substantial evidence that workers on strike are both more probably and of longer duration in periods of relative prosperity (Ashenfelter and Johnson, 1969; S. Vroman, 1989; Cramton and Tracy, 1994, Harrison and Stewart, 1994; Dickerson, 1994). Moreover, there is also considerable evidence that the availability of unemployment benefits influences strike action (Reder and Neumann, 1980; Hutchens et. al, 1992).

Another implication of the Hicksian model is that anything strengthening the resistance of employers will lower the EC curve, thus lengthening expected strike duration and reducing the expected wage settlement. Therefore, firms will be more probably to resist and less probably to increase their wage offers very much as the strike proceeds if they are less profitable, cope with an elastic product demand curve, can accumulate inventories in advance of a strike, can hire replacement workers from other firms in the industry (Unterberger and Koziara, 1980; Schnell and Gramm, 1994). Such an inter-firm relation can be considered as a barrier for wage spillovers from one firm to another in the same industry.

The third implication is that strikes seem to be unreasonably wasteful. If the expected settlement of $W_{0}$ had been reached without a strike or by a short strike, both sides would have been spared some losses. When strikes are very costly to both parties, they might agree in advance of a contract's expiration date to certain bargaining procedures that will help to prevent future strikes. There is certain evidence that strikes are less frequent and shorter when the costs of any strike to both parties are probably to be higher (Reder and Neumann, 1980; Kennan, 1986).

As a second model of bargaining, we will discuss the exchange theory of Kuhn (1974) in the context of collective bargaining agreements. In the model developed by Kuhn (1974), several terms are pertinent to the analysis of power. Power is concerned with the kinds and quantities of goods and bads involved in interactions between parties. Bargaining power is the ability to get wanted goods on advantageous terms that is by giving relatively little in return. A transaction involves two mutually contingent decisions. Only if the benefits equal or exceed the costs to each party separately will the transaction be concluded. Each party must choose 
between two goods, the one to get and the one to give up. We can join these two items for each party and say that one party's effective preference is his or her net desire for the good held by the other. In wage bargaining, these are money wage and labor. Each party's own effective preference is its resistance point that represents the party's minimum acceptable terms. The target of one is usually selected in a way that represents the other's resistance point, that is, one party's best estimate of the other's effective preference.

Union-management relations characteristically involve both threat and stress. The threat comes first, "Agree to this or there will be a strike". The threat is always present implicitly even if no one ever mentions it. If the threat does not produce agreement, it is ultimately transferred to the stress of actual strike. The usual unionmanagement relation is that of a threat that can later be converted into a stress. A strike can do this since it is relievable.

The relevancy of Kuhn's model for the wage spillovers is as follows: A complication of bargaining is that parties pay attention to the possible tactical or strategic effects of their present negotiations on any other negotiations, whether involving parties other than themselves or themselves at some future time. There are strategic as well as tactical relationships among successive bargains. If one party has won a very advantageous settlement in a given year, it may relax and feel a duty to go a bit easy next time by displaying a longer effective preference. If the union accepted substandard settlement one year since employer was in economic difficulty, it may expect reciprocal generosity in the future when management is in a better financial position; in many cases employer may feel obliged to respond (Herman, 1998:221). In sum, not only do present behavior affect expectations about future, but also expectations affect present behaviors. There may be interrelations among different negotiations going on more or less simultaneously but with different employers, whether those employers deal with the same or a different union. Pattern setting is one such relation. The effective preferences of both parties are shorter if they are aware that they are pattern setters than if they are bargaining merely on their own behalf. In the former case, any concession made by either union or management means a potential loss, not only to the principals directly involved but also to all other unions and managements that follow the pattern. Knowledge that one will be a hero with unions and managements elsewhere for putting up a successful fight may further shorten a negotiator's effective preference (ibid., 222). Pattern followers tend to have 
their effective preferences move at the outset of bargaining to approximately the positions already set elsewhere. Pattern-following bargaining is generally quicker and easier since each party knows at the beginning nearly where the opponent's effective preference is. However, even a pattern follower may have problems that lengthen negotiations and some supposed pattern followers may propose something better for the union and management than emerges in the pattern. In conclusion, Kuhn's exchange theory makes wage spillovers possible over time and space.

Walton and McKersie (1991:4-6) propose that the process of labormanagement negotiation comprises four different subprocesses: distributive bargaining, integrative bargaining, attitudinal structuring, and intraorganizational bargaining. In the first subprocess, the parties bargain over division of a particular pie and one party's gain is a direct loss for the opponent. Thus, this approach can theoretically be expressed as a fixed-sum game. In the integrative bargaining subprocess, both parties search for solutions that would increase the size of the pie. In game theory models this approach is described as a variable-sum game. At this step, the targets of parties need not necessarily be in conflict. The third subprocess, attitudinal bargaining, represents a major departure from components represented in other bargaining theories. This subprocess identifies the quality and type of relationship between labor and management. Attitudinal structuring includes the parties' efforts to shape their opponents' behavior. Walton and McKersie (1991:5) claim that the negotiators' own behaviors may have impacts on the attitudes and behaviors of their opponents. The first two bargaining subprocesses can be treated as issue-oriented decision-making processes, while attitudinal structuring is connected with the mood and ambience existing at the bargaining table. The final subprocess, intraorganizational bargaining, refers to the internal negotiations that occur with the respective organizations. Walton and McKersie (1991:9) admit that neither the union nor the management has a homogeneous structure. Each party should resolve their internal conflicts before it can reach a settlement with its bargaining opponent.

Walton and McKersie (1991:42-45) discussed another valuable concept that is called as the notion of a contract zone. The zone may have a positive or a negative range and its limits are decided by the bargaining parties. For the wage bargaining, there is a wage at which management would be losing money and thus might have no incentive to remain in business and employ workers. On the other extreme, there is a level of wage at which workers decide to look for alternative employment. The parties 
have opening offers, target positions, and resistance points within each contract zone. A resistance point within the range of potential solutions specifies the minimum settlement level that the party would be willing to accept. Beyond that point, the party would refuse to settle and therefore would be willing to recognize and respond to the economic consequences of a bottleneck.

Figure 5.2: Contract Zones for Wages

\section{a. Pasitive Cantract Zane}

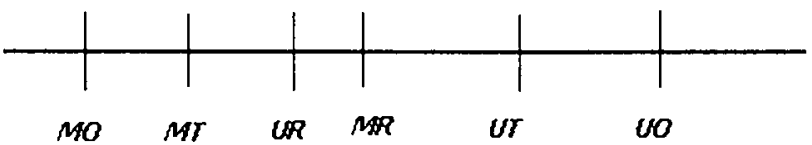

\section{b. Negative Contract Zane}

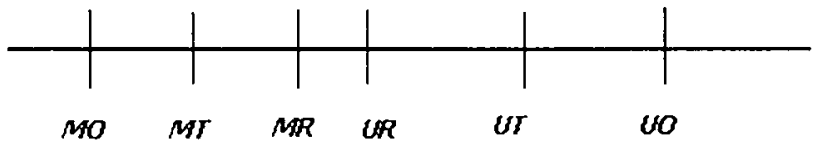

$M$ Management, $U$ Union, MO, VO Opening Offers MT, UT Target Positions, $\quad M R$, UR Resistance Points Source: Walton and McKersie (1991:42-45)

Figure 5.2 presents two probable positions of resistance points in labormanagement negotiations. In the case of a positive contract zone, the union and management resistance points overlap; there is a range of possible settlements that the parties would prefer to a strike. A negative contract zone exists, such as in panel b, whenever the resistance points do not overlap.

In their pioneering work, Nickell and Andrews (1983) derive a two-equation model determining real wages and employment from an explicit firm-union bargaining procedure. Consequently, they try to draw conclusions on whether unions have some impact on employment. This model, where unions and employers bargain on wages, while employers set independently the wage rate is called as right-tomanage model. Moreover, right-to-manage model is characterized by profits and union utility that depend on wages and employment and the bargaining solution is the 
Nash solution (Veen, 1997). According to Nickell and Andrews (1983:202), unions have unfavorable impact on employment, however, if unions and employers bargain equally about employment and wages, the consequences would be beneficial to both parties and would lead to a higher level of employment than solely bargaining on wages. Moreover, Nickell and Andrews (1983:202) believe that introduction of unions in a decentralized economy have considerable employment effects.

Layard et al. (1991:85), in comparing decentralized and centralized bargaining, claim that under decentralized bargaining the bargainers take the national level of job opportunities as given and ignore the effect of their own decisions upon the job opportunities open to other workers. However, under centralized bargaining, when one union bargains on behalf of the entire workers, this externality is internalized. Therefore, they conclude that under centralized bargaining the union is not likely to push for wages that will cause unemployment. In sum, centralized bargaining is contributing to full employment since the bargainers internalize all the employment effects of the wage bargaining. This result has indirect spillover impact all over the economy.

The contribution of Walton and McKersie (1991) in to the bargaining literature is invaluable on several grounds. First, they allow us to view collective bargaining not as an unidimensional contest of labor versus management but rather as a complex, interrelated process of a distributive, integrative and intraorganizational bargaining as well as attitudinal structuring. Second, their framework puts forward that any single action by a union or a management negotiator can induce multiplicity of responses within the four subprocesses. Finally, they present the existence of strong links among bargaining behaviors, tactical decisions, and the goals of the negaotiating parties. In their view, by observing behaviors we can deduce much about the agendas and targets of the parties. The spillovers in the context of this model are not simply in the form of imitating wage increases. What is followed or imitated in this model may be bargaining behaviors, strategic and tactical decisions, and objectives of the bargaining parties.

Holden (1988) discusses the local and central wage bargaining. ${ }^{24}$ The local wage bargaining is modelled as an asymmetric Nash bargaining game. A change from

\footnotetext{
${ }^{24}$ For a detailed discussion of the previous studies on wage drift, see appendix of chapter 7.
} 
a system of central wage bargaining to local system exhibits the usual income and substitution effects (Holden:1988, 97). Holden (1988) shows that when bargaining takes place on two levels, the union is able to obtain more of both employment and wages and this will tend toward higher employment and a higher wage by assuming both goods are normal. This result is clearly contrasted with the well-known proposition that bargaining on two levels increases wages and reduces employment. Holden's hypothesis aims to model two levels of the Norwegian system of wage determination. Holden (1987) studies the empirical application of local wage bargaining model for Norway. The model also attempts to explain the modesty of central trade union in most of the wage negotiations in Norway during the early 1980s. According to Holden (1988:99), the central union may contentedly focus on the employment level in central negotiations while be aware of the fact that higher wages will be attained through local bargaining. Holden (1989) attempts to explain the wage drift in the manufacturing sector in Norway. It is found that central wage settlements have a significant effect on aggregate and relative wages in the short run. However, the size of the wage drift is so large that it might have offset the central wage increases (Holden ,1989: 430). As it is predicted by the theoretical model, there is no evidence that such offsetting effect occurs. Holden (1989) also finds out the determinants of wage drift as size of inventories in industry, vacancy rate, payroll tax changes. There also appears to be an error correction mechanism operating on relative wages, in the sense that, if the relative wage in an industry is low compared to with its normal level, then this will tend to raise wage drift in that industry (Holden, 1989:431). In another study, Holden (1998) whether the previously explained offsetting effect is relevant for the Nordic countries is analyzed. In Nordic countries, wage setting takes place at two levels, nationally or by industry and at the firm level where wage drift occurs. For all countries ${ }^{25}$, where a switching regression model is employed, there is little or no offsetting the central increase in wage drift.

Moene (1988) concentrates on how workers' incomes, profits, and equilibrium employment is affected by the rules of local wage bargaining games. Moene (1988, 480-81) finds out that an increase in bargaining power of the unions leads lower employment when slow-downs are used whereas it causes higher employment when

${ }^{25}$ The ccuntries studied are Denmark, Finland, Norway, and Sweden. 
work stoppages are used. Moreover, equilibrium wages and employment levels are not necessarily moving in the opposite direction.

Andersen and Risager (1991) estimate a bargaining model for Denmark by using the models proposed by Andrews and Nickell (1983) and Hoel and Nymoen (1988). Andersen and Risager (1991:567) claim that among the Scandinavian countries only Denmark suffers from substantial unemployment and this necessitates a particular study for wage formation in Denmark. Their major results are that wage setting in Denmark is not characterized by money illusion, shorter working hours lead in the long run to full wage compensation and a fall in total number of hours worked, and expansionary demand management policies induce wage increases which finally eliminate the expansionary effects on activity (Andersen and Risager, 1991:575).

The Nordic countries of Denmark, Finland, Norway, Sweden, and Iceland share a common labor market and a long-standing political, cultural, and scientific corporation. The term "Nordic Model" is used to describe the distinctive common elements of their systems of social welfare provision, economic routing, labor market regulation, industrial relations, and their complex articulation at the national level (Alestalo and Kuhnle, 1984; Brunn et al., 1992; Kjellberg, 1992; Schiller, 1994). However, there are many significant differences suggesting the historically particular national environmental pressures on the developments and strategies within each country (Ahrne, 1988; Andersson, 1993).

Industrial relations in the Nordic countries are often given the label of corporatist. But corporatism is a particularly bad choice of word to describe the Nordic system of centralized wage setting since corporatism has connotations of anticompetitive practises and trade protection (Moene and Wallerstein, 1995a). In fact, the Nordic variety of corporatism was associated, not with protectionism and monopolistic pricing, but with free trade and subsequent need to remain competitive in export markets. In Nordic area, the principal supporters of centralized bargaining were not the unions at all, employers. This does not mean that impacts of unions are immaterial. In fact, the establishment of centralized bargaining necessitates cooperation from both parties. Therefore, the Nordic countries can best be considered models of highly centralized systems of. wage bargaining rather than corporatist. Moreover, many scholars prefer to use the term "bargaining society" that is pioneered by Johansen (1979). Johansen (1979) refers to political economies in which distributional questions are resolved by negotiations among a small number of 
encompassing organizations rather than by open conflict, market competition, or directives issued by a central agency. Whether the centralized wage-setting institutions that characterize the Nordic economies in particular enhance economic efficiency and/or macroeconomic performance has been the subject of continuing controversy (Moene et al., 1993; Calmfors 1993a; Lindbeck 1993). On one side are those who believe that centralized negotiations improve economic performance by allowing wage setters to incorporate various externalities into their decisions that would otherwise be ignored by actors with only local responsibilities (Wallerstein and Golden, 1997a:699). On the other side are those who believe that any centralized system of wage determination is likely to suffer many of the same informational and incentive failures as central planning (ibid.; 699).

Recently, some studies (Calmfors, 1993b; Moene and Wallerstein, 1993; Reder and Ulman, 1993; Streeck, 1993; Lindbeck and Snower, 1995; Iversen, 1996; Pontusson and Swenson, 1996) have proposed that centralized bargaining has turned out to be less efficient or less feasible even though it is not inefficient in principle. According to these views, in the last two decades, European economies have changed in ways that have reduced the efficiency or the practicality of centralized systems of wage determination. In the literature, three possible explanations for the trend towards decentralized bargaining are changes in production, changes in occupational structures and union membership, and increased integration in world markets.

Streeck (1993) and Pontusson and Swenson (1996) point out the rise of flexible specialization and diversified products. According to them, the peculiarities of centralized bargaining systems of the Scandinavian countries have steadily become less compatible with the post-Fordist production processes and the needs of many establishments. Olsson (1991), Moene and Wallerstein (1993), and Lange et al.(1995) claim that changes in the composition of union membership have reduced the ability of trade unions to act collectively. Reder and Ulman (1993) argue that unions gain from the centralized wage setting since they have the ability to take wages out of the competition at the national level. When the goods flow freely throughout the European Union the basis of centralized bargaining from the union point of view lost its meaning.

After analysing the general tendencies of Scandinavian models of wage bargaining, we will discuss the various kinds of changes in the centralization of wage setting in Sweden, Norway, Finland, and Denmark. 
From 1956 through 1982, Swedish private sector wage bargaining was characterized by a high level of centralization and a low level of government involvement. Since 1982, the level of centralization has fluctuated from one bargaining round to he next, and govemment involvement in wage setting has increased. In spite of attempts to restore centralized bargaining in the mid-1980s and again in the early 1990s, by 1993 it was clear that the era of centralized bargaining was over in Sweden (Wallerstein and Golden, 1997a). In the period 1956 to 1982, the main blue-collar union confederation- Landsorgnisationen (LO) and the main employers' association- Svenska Arbetsgivareforeningen (SAF) negotiated central agreements that covered most of the blue-collar private sector employees. In principal the frame agreements were simply advisory. The legally binding contracts were signed at the industry level (Olsson, 1991:28). In 1982, the statutes of SAF were changed, reducing the peak association's authority over its members (Wallerstein and Golden, 1997b). In 1983, SAF initially refused to bargain centrally with LO (Wallerstein and Golden, 1997a). Since 1983, the initial level of bargaining has oscillated between the confederal level and the industry level (Ahlen, 1989). Finally, in 1990, the SAF board announced the discontinuation of its bargaining department, thus eliminating SAF's capacity to engage in national level bargaining (Wallerstein and Golden, 1997a).

Sweden is the only Nordic country in which the government almost never directly participates in private sector wage setting. The most extensive government involvement in private sector wage setting occurred in 1991 to 1992. In this period, the government introduced a two-year wage freeze coupled with a ban on strikes and a ceiling on price increases (Wallerstein and Golden, 1997b). The measure was defeated in parliament causing social democratic government to resign. By the next bargaining round in 1993, the liberal government was uninterested in sustaining centralized bargaining (Martin, 1995).

Perhaps the most dramatic instance of union-sponsored wage equalization occurred during the postwar years in the Scandinavian countries of Norway and Sweden. An ambitiously egalitarian wage policy was adopted by the central bluecollar confederations in the early 1950 s and pursued steadily for three decades (Moene and Wallerstein, 1995a:79). For much of the postwar period, the wage-setting pattern in Norway followed the similar paths of Sweden: a phase of initially less centralized wage setting followed by a long period of a high level of confederal 
control over the process. However, the extent of the confederal participation in wage setting has diverged between Sweden and-Norway. Whereas in both countries, wage setting became less centralized in the early 1980s, in Norway highly centralized wage setting was restored by the end of the decade (Kahn, 1995). Finally, the Norwegian government has been more frequently and more intensely engaged in private sector wage setting than the Swedish government.

Industry-level bargaining predominated in the early 1950s and in the early 1980s. From 1958 to 1982 , and after 1988, the primary negotiations have been conducted at the confederal level (Wallerstein and Golden, 1997a). In 1973 and from 1975 to 1980, wage negotiations took the form of combined settlements in which the government participated in the bargaining process along with the Landsorganisasjonen I Norge -LO, the representative of mostly blue-collar workers, the Norsk Arbeids-Giverforening -NAF, representative of employers ${ }^{26}$, and the representatives of farming and fishing associations (Wallerstein and Golden, 1997a). In 1978, the tripartite negotiations broke down and parliament sent to LO and NAF into compulsory arbitration. Moreover, in 1978 and 1979, the government proclaimed a wage and price freeze, suspended renegotiations over a cost of living adjustments, and, for the first time prohibited plant-level bargaining (Wallerstein and Golden, 1997a). In 1988, the LO and NAF negotiated a contract conditional on the enactment of a law prohibiting wage increases for workers outside the LO from being greater than those received by LO members (Moene and Wallerstein, 1995a). Moreover, plant-level bargaining was disallowed during first year of the contract. Since 1989, collective bargaining has continued at the confederal level without direct government intervention. The restoration of centralized bargaining in Norway in the late $1980 \mathrm{~s}$ contrasts piercingly with the extensive decentralization that arisen in Sweden.

The path of wage setting in Finland has diverged from both the Norwegian and Swedish patterns. In the early 1950s, wages were largely set by the government in consultation with the union and employers' confederations. After 1955, government intervention diminished and wage agreements were concluded at the industry or confederal level (McDaid, 1995). Government participation has gained greater

\footnotetext{
${ }^{26}$ The new name of this organization is Naeringslivets Hovedorgainisasjon-NHO.
} 
magnitude in the late 1960 s when a period of national-level tripartite bargaining commenced that has last to the present.

The history of collective bargaining in Finland after the postwar era can be divided into three periods (Wallerstein and Golden, 1997a). The first period, $1945-$ 1955, was characterized by heavy government regulation of wages and prices. However, this does not mean that main labor market organizations had no impact. Their representatives also included in the board that managed the wage and price controls. The second period of collective bargaining started with a general strike in 1956 as prices jumped and unions asked for the compensation of this jump. The general strike was come to an end with a one-year agreement between the Suomen Ammattilittojen Keskusjarjesto- SAK, main blue-collar federation and the Suomen Tyonantajain Keskusliitto- STK, main employers' confederation, followed by three years of bargaining at the industry level.. The third period of collective bargaining began in 1968 when the government announced the suspension of the three-year agreement by consulting with the central organizations following a large devaluation in 1967. The usual pattern since 1968 has been for industry-level negotiations to take place within a framework negotiated by the central organizations. However, the framework agreement is not compulsory. Although the government does not sign the central agreements, it has been directly participated in central negotiations for the past three decades.

The trend for decentralization in the level of collective bargaining has been keenly supported by the key Finnish employers. They have also called for greater employee flexibility on the labor market and in the enterprise. Employer demands for the decentralization of collective bargaining reached it peak at the end of the 1993 as central organization of employers rejected to engage in negotiations with trade union confederations (Brunn, 1994). Consequently, the bargaining rourd ending in the first half of 1994 was accomplished at union level and produced a wide variety of agreements. An appealing feature of this decentralized collective bargaining has been the formation of cartel-like groups of unions within and between the central trade union organizations to help coordinate union demands (Jensen et al., 1994).

Danish wage setting followed a similar path that of Sweden: a prolonged period of centralized wage setting starting in the 1950 s and lasting until the early 1980s, followed by a period of declining confederal involvement in wage setting (Wallerstein and Golden, 1997a). What is different from the Swedish pattern is the 
government mediation or direct wage setting by parliament until the early 1980 s. Furthermore, the extent of decentralization of Danish wage setting is modest. Although the role of central organizations has weakened, the confederations are replaced by five bargaining cartels that cover the whole labor market (Scheuer, 1992).

Throughout the postwar period, collective bargaining in Denmark followed a sequence and a timetable that was originally negotiated by the Landsorganisationen $i$ Danmark- LO, main union confederation and the Dansk Arbejdsgiverforening- DA, the Danish employers confederation in 1936 and subsequently amended in 1951 (Wallerstein and Golden, 1997a). The general issues including general wage increases were negotiated at the confederal level while the specific issues were agreed upon at the industry level. In practice, every bargaining round from 1959 through 1972 ended up in mediation. When mediation is not successful, the government frequently intervened (Due et al., 1994).

After 1981, the role of confederations in bargaining rounds has been declined. In 1985, there were no agreements at the industry level or in mediation (Wallerstein and Golden, 1997b). Further important change in the bargaining system took place in the period from 1989 to 1991, when a series of mergers among employers' organizations resulted in the establishment of a single association for all industrial employers, Dansk Industri- DI (Scheuer, 1992). On the one hand, the establishment of DI characterized a trend towards the centralization of bargaining, On the other hand, the foundation of DI stood for an embedded decrease in the power of the employers' confederation in the bargaining. A parallel tendency was also observed in the employees' side. In 1990, a proposal within the LO to respond merging the LO's affiliates into five bargaining cartels was accepted but it was cancelled in 1992 (Wallerstein and Golden, 1997b). However, in the subsequent period until today it is possible to see the formation of new cartels. Finally, it can be claimed that Danish system is in a way to move a new path in which the main agents are neither the national unions and industry level employers' associations nor the peak associations. The agents of new system are five bargaining cartels and their corresponding employers' organizations.

The 1980s may be considered as a decade of major change in wage-setting applications and institutions in Nordic economies. The remarkable characteristic of the records we have analyzed is that in Nordic region diverse national experiences are observed in terms of the changes in wage-setting patterns. In Denmark and Sweden, 
the impact of the centralized union confederations and employers' associations in wage setting has been considerably diminished. However, only the Swedish case reveals obvious trend towards decentralization in which we see a broad change toward greater discretion over wages at the industry or plant level. The new Danish system of five bargaining cartels is barely an indication of a move toward industry-level bargaining. The wage bargaining in Norway is a restored version of a system of centralized bargaining that had existed previously. Thus, it can be claimed that the Norwegian wage bargaining system has been recentralized in 1980s. Finally, the experiences of Finland show no substantial change in the level of bargaining. The most probable account of why a permanent decentralization of wage bargaining occurred in Sweden among the Nordic countries in the 1980s that is based on an observable difference between Sweden and the others is that the political aims of Swedish employers contributed to their opposition to centralized bargaining (Wallerstein and Golden, 1997a). Sweden stands out among the other Nordic countries in the extent of political antagonism between the leaders of the employers' confederation and the unions (Elster, 1989).

What is important for us is to find some evidences for the wage spillovers from the Nordic experiences of wage bargaining. Trade unions can affect the rate of wage inflation by creating a wage transfer mechanism based on criteria of horizontal and vertical equity in the structure of relative wages. To create such a transfer mechanism is more likely to occur in a centralized wage-setting system. Union movements have become more fragmented in Nordic countries in 1980s. It is possible to observe a remarkable change in terms of the wage dispersion. In 1980, the ratio of earnings at the $10^{\text {th }}$ percentile to earnings at the $90^{\text {th }}$ percentile was 0.41 in Finland, 0.47 in Denmark, 0.49 in Norway, and 0:50 in Sweden while the figures are 0.40, $0.46,0.51,0.46$ respectively in 1995 (OECD, 1996:61-62). Therefore, it is clear that the wage equality is damaged more in Sweden with a move toward decentralization than in any other country while we see improvement in Norway that is keeping centralized wage- bargaining practises. In conclusion, the decentralization of wage bargaining and fragmentation of union movement cause serious difficulties in transmission of wage changes from one sector to another and create more inegalitarian wage structure. 


\subsubsection{Wage Leadership Hypothesis}

The wage leadership hypothesis postulates that the level of money wages in any one sector of the economy is determined institutionally by comparison to a given set of wages in the wage leading sector(s). The essential notion of the wage leadership hypothesis is that a certain key group or groups of industries act as pattern setters in wage determination. It is argued that there is a causal ordering in the wage setting patterns in that real wage increases in the leading sectors produce, in the nonleading sectors, wage increases that are independent of the nominal wage increases in the nonleading sectors that are imputed to the market forces operating on the nonleading sectors.

Seltzer (1951) is the first author that defined pattern bargaining and analyzed for the U.S. economy. He defined pattern bargaining as the negotiation of labor agreements by reference to one agreement, called key bargain which serves as a standard or model for many others (Seltzer,1951:319). He observed that the negotiations carried by the United Steelworkers of America are followed by other industries. However, his study does not contain a formal econometric model and a test of the above explained behavior of following negotiations rather it leads to some ad hoc observations.

Maher (1961) on the basis of a detailed analysis of contract terms found the existence of the basic industries of the U.S. economy belonging to the key group. He found that there are inter-connections among the unions in the group. He further concluded that the wages in the basic group conform to a common pattern as bargaining in these industries is tied together because of input-output nexus, the similarity of internal technological and economic conditions that will produce similar responses to external changes, large unions and high concentration. The wages in these basic industries conform to a similar pattern and wages in industries outside this basic group follow the wage pattern of the basic industries.

The concept of wage leadership was explicitly introduced into the models of wage determination by Eckstein and Wilson (1962) and it can be treated as the first serious attempt to test wage leadership. Their paper presented an empirical model to explain the behavior of wages in the wage rounds of U.S. manufacturing industry. They advanced five hypothesis about the determination of wages (Eckstein and Wilson, 1962:381-87): 
- Wages are set by a bargaining process,

- Both product and labor market factors influence wage determination,

- Profit and unemployment rates are sufficient to explain most of the variation in the rate of increase of wage rates,

- Wage determination in a group of heavy industries is interdependent,

- Wages are determined in wage rounds.

Eckstein and Wilson (1962) assumed eight heavy industries as the key group of industries. The common characteristics of these industries are that they are highwage industries, have strong industrial unions, consist of large firms with a considerable market power, and are situated in the same geographical area. First, they hypothesized that key group wages are set by a bargaining process in which the relative opportunity costs of concession to unions and employers in the key group are related to the unemployment rate and profit rate within the key group as a whole. Profits and unemployment proved to be significant variables as they explained most of the variation in key group wages. Interestingly, productivity and consumer prices do not seem to be significant in their regressions. Second, they run regressions for the wage determination outside key group using key wages and industry specific unemployment and profit rates as independent variables. In eight industries out of eleven, coefficients on the key wages were found to be positive and significant. Therefore, they concluded that wages in the nonkey group are largely determined by spillover effects of the key group wages.

The study of Eckstein and Wilson (1962) has various defects even though it is an important milestone amongst the wage determination studies. First, there is no exact criterion for defining an industry as within the key group and the basis of their classification is an ad hoc judgment. Second, which bargain functions as key bargain within the key group is not clearly identified. Finally, one of its deficiencies is later found by Eckstein himself (1968). Eckstein (1968) found a new spillover channel from construction to durable manufacturing that was defined as key group in the previous study. Hence, the key group is no longer the key group.

Snodgrass (1963), using the statistical information about the uniformity of cumulative wage changes in certain manufacturing industries, tested the hypothesis of pattern bargaining among manufacturing industries and the impact of key bargains on the wages elsewhere. A pattern is said to consists of a group of wage setting units, a 
leader and a number of followers. The essence of pattern bargaining is that the actions of the followers are basically reactions to those of the leaders. The conclusion reached by Snodgrass (1963) is that pattern bargaining has its role in determining wage rate changes in U.S. manufacturing, but the key industries are limited to only steel and auto.

McGuire and Rapping (1968) attempted to determine whether traditional demand and supply variables in addition to bargaining variables play a role in the determination of U.S. manufacturing relative wages and to distinguish spillover effects from labor supply effects. For this purpose, they estimated two equations, one for the market model and one for the spillover model. In the market model, they regressed each industry's one period lagged change in wages, change in value added, change in national and state manufacturing industry wages on the change in nominal wages for each industry. Most of the variation in money wages are explained by national and state average manufacturing wages, where local wages are found to be more important. They chose the steel and auto wages as leading wages and used them as independent variables for the spillover model. These sectors are chosen on a priori grounds. For five industries the wages in steel industry, and for ten industries wages in the auto industry are observed as significant. As a result, although they claimed that market variables play an important role in the manufacturing sector's relative wage determination process, they did not completely reject the importance of collective bargaining and spillover effects. In another study, McGuire and Rapping (1966:498) criticized the spillover theory because of its inability to specify unambiguously the spillover domain. Moreover, the counterpart of this difficulty in the market model is the specification of the alternative wage domain. According to McGuire and Rapping (1966), these two domains overlap creating a serious identification problem. The main question is "Do spillovers imply a smaller dispersion than market forces?". It is not possible to identify that wage dispersion" is removed by either spillover forces or market forces since the effects are overlapping. They concluded that spillovers do not necessitate a smaller wage dispersion than market forces for the same set of industries (McGuire and Rapping,1966:501). In a further study, McGuire and Rapping (1970) demonstrated the superiority of market model against spillover model and found empirical evidence that local labor market conditions affect local wages. In their studies, however, McGuire and Rapping (1966, 1968, 1970) choose the leading 
sectors arbitrarily and do not assume a considerable spillover from union to nonunion. Therefore, the results obtained by these studies are incomplete and misleading.

Turner and Jackson (1970:847-48) claimed that wages will increase in the leading sector at the same rate as real labor productivity is growing in this sector. However, money wages in other sectors tend to follow the rate of wage increase established in the leading sector, so that the rate of money wage inflation is uniform across the economy. In their cross-country study of 35 countries for the period 1956 1965 , sectors with the highest productivity growth were chosen as the leading sectors. Turner and Jackson (1970) found a considerable evidence for their argument. However, their evidence does not constitute a direct test of the wage leadership hypothesis as their data do not contain any measurement of labor productivity growth but instead consists of a number of judgmental assumptions about its dispersion. Finally, Tumer and Jackson (1970) fail to consider the impact of relative price movements predicted by their model and the prospects that such differential productivity growth patterns may pose for output and employment in the slow growth sectors.

Reuber (1970) tried to identify the determinants of money wage changes in Canadian manufacturing industry. His estimates emphasized that general economic conditions such as level of unemployment and general level of wages have an important influence on wage changes. Reuber (1970:463) defined three key groups to test wage leadership hypothesis; first is the same defined by Eckstein and Wilson (1962) for U.S. economy; second, key group is defined in relation to certain characteristics of Canadian industries such as the strength of unions, the relative level of wages, the rate of wages grown in the past, and relative size of labor force; third, key group is identified according to collective agreements covering 500 or more employees. However, Reuber (1970) found no substantial evidence to support the wage leadership hypothesis for the first two definitions of the key groups. For the third definition, there is small evidence in favor of wage leadership hypothesis. As a result, he concluded that a new definition of key group for Canadian manufacturing industry is needed.

Sparks and Wilton (1971) analyzed the effects of negotiated wage increases for Canadian manufacturing industry. They claimed that the grouping or pooling of industry explanatory variables to form key group variables as done by Eckstein and Wilson (1962) would be inappropriate for individual contracts running over different 
time periods. Furthermore, they also suggest a pooling or averaging of wage changes into one dependent variable if one contends that spillovers are so pervasive that the key group of industries can be treated as a unit. On the other hand, the simple introduction of a past key settlement which might be expected to influence a current bargain presents problems in identifying the key contracts and obscures the role of other variables by increasing multicollinearity. In order to capture the interindustry effects, Sparks and Wilton (1971) introduces a variable defined as the current base rate at the time of the bargain divided by a four quarter average of average hourly earnings in manufacturing. Its effect should be negative since wage earners with low basic rates relative to the average will press for higher settlements. Moreover, they also included an interaction variable which is the multiplication of productivity with the above relative variable. However, they found that these variables play a minor role in the wage determination as compared to market variables such as productivity, price changes, profits, and unemployment. Their formulation of spillover variable is defective in the sense that it does not capture the whole effect of spillover from union to non-union wages, rather it takes into account intra-contract effects of wage settlements. Therefore this study is limited in its scope.

Kleiman (1971) studied spillover effects in relation to plant size for Israeli manufacturing industry. He evaluated the changes in wages and plant size in terms of wage indices without carrying out a regression analysis. He concluded that wages tend to be higher as the plant size gets larger. Therefore, the concentration of employment in large plants raises the weighted average wage rate for an industry as a whole. However, he did not find a support for the claim that such concentration also raises the level of wages in the industry's smaller plants. The concentration may be an important determinant of wage spillover. Kleiman (1971), however, did not provide a serious econometric analysis and accordingly concluded on a priori base.

Anderson (1972) investigated the wage spillover mechanisms for both U.S. and Canadian manufacturing industries. He informally chose U.S. and Canadian durable goods sectors as representing wage leaders and specified three conditions for the existence of a spillover mechanism (Anderson,1972:182).

- An exogenous wage must be superior source of wage compromise for the bargainers within the industry in question; 
- The predicting wage must consistently produce livable settlements for both sides of the bargaining relation and this requires some market interrelations between them;

- No other distracting expectations can exist which deprives the influencing wage of its expectation satisfying role.

Anderson (1972) claimed that U.S. durable goods industry meets these three conditions and has a pronounced spillover relationship while Canadian one fails to meet first and last conditions and has no such a spillover relation. All these three conditions, however, are subjectively specified and not verified by formal test procedures.

Dynamic market interdependence hypothesis proposed by Brechling (1973) states that there is a general dependence of each sectoral expected wage change on possibly all actual wage changes. The expected wage change in sector $i$ is allowed to be influenced by actual wage changes in sector $j$, so that the actual wage change in sector $i$ responds not only to market conditions in sector $i$ but also to those in sector $j$. Brechling (1973) examined two versions of the dynamic market interdependence for U.S. manufacturing industry. First, it was assumed that regions with relatively low unemployment rate were the leaders which influenced wage changes in other regions and there was no transfer from high unemployment to low unemployment regions. The empirical support for this hypothesis was found to be very weak. Second, it was assumed that regions with relatively high average earnings were the leaders which influenced wage changes in other regions. States were ranked from high wage to low wage states, and mean wage change of the leaders was assumed to influence the expected, and hence, the actual wage change of followers. In this model, the leaders do not respond to wage changes among followers, but instead their expected wages are assumed to be related to their own past unemployment. This dynamic market interdependence is unidirectional as there is no tendency to migrate from high earnings to low earnings regions. Some empirical support for this formulation has been found by Brechling (1973).

Edgren, Faxen and Odhner (1973) hypothesized a model in which wage leadership is treated in the context of constraints on price movements established by the competition in international export markets. In the study of Edgren, et.al. (1973) for Sweden, a key assumption is that the tradable sector acts as a wage leader with 
respect to nontradable sector. Nominal wage increases in the tradable sector adjust in the long run to the wage increases in the sector, the sum of productivity growth and international inflation. Wage increases in the tradable sector are assumed to be transmitted to the rest of the economy through bargaining institutions and market forces. Inflation imported by the intemationally competitive sector spread through the rest of the economy because of the wage-following behavior of nontradable industries. For the empirical performance of the model, Edgren, et.al. (1973) relied on descriptive statistics related to Swedish economy and the model was verified without any rigorous econometric investigation. It can be concluded that the model proposed by Edgren, et.al. (1973) can be viewed as a theory of international transmission of inflation rather than a wage leadership theory.

Mulvey and Trevithick (1974) carried out a study on wage leadership hypothesis for Irish manufacturing industry and hypothesized that there is a key group of skilled manual occupations, which is enabled, by virtue of a persistent excess demand for their services, to strike wage bargains in advance of the remainder of the labor force and that these bargains are of a magnitude which reflects the economic circumstances of the key group. It is also assumed that the key group serves as wage leader because of the existence of wage transfer mechanism based on the widespread acceptance of vertical and horizontal equity. Mulvey and Trevithick (1974:2-4) chose the wage leader as electricians having the lowest unemployment rate that shows an excess demand for this particular group and explained the wage transfer mechanism from key sector to nonkey sectors also by using this excess demand as an explanatory variable in aggregate wage change equation. Moreover, they used a freeze dummy to take into account the effects of wage freezes applied by Irish government. Finally, they verified the hypothesis by finding the significant coefficients on unemployment rate of electricians. However, the approach of Mulvey and Trevithick (1974) is insufficient as an institutional approach since their model obviously does not explain the institutional forces behind wage transfer mechanism.

Eatwell, Llewellyn and Tarling (1974) presented a cross-country analysis for 15 industrial countries for the period 1958-67 to test the wage leadership hypothesis of the determination of money wage inflation. For each country, Eatwell, et.al. (1974:516) selected 3 key industries with the fastest productivity growth and found that there is a strong tendency for the countries in which the rate of growth of productivity in the top three industries is high to have relatively high rates of growth 
of wages. They claimed that the overall rate of increase of money wages is linked to the rate of increase of productivity in those sectors with the fastest productivity growth. The behavioral assumption behind this idea is that key industries dissipate a high proportion of their large gains in productivity in the form of higher wage and that gains are not absorbed in higher profits, the higher input costs attendant upon unitcost inflation in other sectors, or by substantial price cutting (Eatwell, et.al., 1974:516). They found that the only divergence from the above explained tendency is observed for the Netherlands; the growth in Dutch wages is significantly higher then the average rate of growth of productivity in the top three industries. Eatwell, et.al. (1974) argued that this is the result of state intervention in the wage bargaining process in the first half of the period and the collapse of incomes policy in the second half of the period. Therefore, Eatwell et.al. (1974:521) run two separate regressions where average rate of growth of money wages is explained by the average rate of productivity in leader sectors; one for including the Netherlands and one for excluding the Netherlands. In both regressions, the coefficient on productivity variable is found to be positive, significant and less than unity in conformity with the hypothesis tested. As expected, the case excluding the Netherlands performs better than the one including the Netherlands. However, it is not clear that the key industries are wage leaders as far as wage growths concerned. For instance, for Sweden, the key industries include petroleum and chemicals but the rate of wage growths in these industries have almost the lowest of the growth rates for Swedish industries. For Japan, wage growth in the key industries is less than in manufacturing industry as a whole. In sum, in the 15 countries examined by Eatwell, et.al. (1974), 8 have key industries with wage growth below the manufacturing average. Hence, it is difficult to accept these industries as wage leaders for the rest of the manufacturing industry and such findings suggest that the high correlation between wage growth and productivity growth in key industries found by Eatwell, et.al. (1974) is misleading. They ignore the effects of other variables such as unionization, unemployment, etc. completely.

Driehuis (1975) investigated the wage determination process via wage bargaining, wage policy and production structure in the Netherlands for the period 1953-72. Driehuis (1975) assumed that the key industries can be found in the manufacturing sector and claimed that the bargainings begin in important branches of industry such as the metal industry and followed by other manufacturing trades, the construction sector, the services sector and at the end by the agricultural sector. 
Drichuis (1975:653-54) treated the whole manufacturing industry as a wage leader for the rest of the economy because of the limited disaggregation of data and estimated separate wage change equations for manufacturing, construction, services, and agricultural sectors. In order to find the determinants of wage changes in the manufacturing sector, three separate equations for contract wages, wage drift, and total wage bill are estimated. Driehuis (1975) found the change in labor productivity, the change in consumer price index, and the change in profit rate as significant factors in the determination of manufacturing industry wage changes. For the remaining three sectors, percentage change in average contract wages in the manufacturing sector, percentage change in productivity, level of capacity utilization, percentage change in unionization, absolute change in social security premiums paid by employers as percent of gross wage, and sector-specific dummy variables are regressed on annual percentage change in wages per worker. For the first three variables, a lag structure is introduced in some equations but how this lag structure is chosen is not explained by Driehuis (1975). The percentage change in average contract wages in the manufacturing sector is used as one of the independent variable to test the wage leadership hypothesis and in all three sectors coefficients on this variable are found to be positive and significant suggesting a substantial spillover from manufacturing industry wages to those sectors. Therefore, Driehuis (1975) concluded that the results verify the wage leadership hypothesis for Dutch economy. This study, as many of the studies in the literature, suffers from the point of choosing a wage leader on a priori judgments. Moreover, by using contract wages instead of wage sum per worker, Driehuis (1975:653) assumed that only key wage bargains spillover from manufacturing to other sectors whereas it is found by the author that trade unions do not play a significant role in wage determination in services and agricultural sectors. Hence, using wage sum may be more appropriate in this context.

Mehra (1976) found no evidence of significant wage spillover and pattern bargaining in manufacturing by using U.S. manufacturing data. Mehra (1976:301302) studied the covariance structure underlying the residual components of wage changes after taking out the effects of the exogenous labor and product market forces on the wage change to test the existence of labor market interdependence. He divided the manufacturing sector into low wage, highly competitive sector on the one hand, and a high wage, highly noncompetitive sector on the other hand. His results indicated that wages in the former group can be explained mainly in terms of exogenous labor 
and product market forces, represented by the consumer price index and the unemployment rate. These results are different from those showing the wage spillover effects of key sectors to other sectors. Wages in the latter group were found to be highly correlated as these sectors share common labor and product markets. The industries in these group comprise the majority of the manufacturing sector. Although wages in this group of industries are correlated, Mehra (1976:308-11) found no evidence of one or two key bargains that would be setting the pattern bargaining.

Econometric models have been estimated to find the spillover from union to non-union and vice versa by introducing a measure of union-non-union wage differential in the wage equations for union and non-union sectors. A spillover from non-union to union wages is present if the coefficient of this wage differential is negatively significant in the union wage equation, while a positively significant coefficient in the non-union wage equation would indicate spillover from union to non-union wages. Studies by Flanagan (1976) and Johnson (1977) using this kind of methodology, though for different time periods, arrived at similar conclusions. Both studies found a negatively significant coefficient in the non-union wage equation, thus arriving at the conclusion that the wage spillover is from non-union to union sectors, and not from union to non-union sectors.

Copeland (1977) used the same data set of Eatwell, et.al. (1974) for the identical 15 countries but by extending the period to 1972. Copeland (1977) also added the employment weighted average of the aggregate productivity growth and the growth rate of prices into the regression equation. As a result of the analysis, Copeland (1977:262) found that aggregate productivity growth explains the growth in wages while the average productivity growth in the leading three industries is not significant. Then, he concluded that wage leadership hypothesis is not sufficient to explain long-run wage inflation process and claimed that it might have a short-run effect on the wage inflation process and this effect is transitory. Moreover, he argued that labor market structure plays a part only in the transmission yet not in the causation of wage inflation. Nevertheless, such an approach cannot be treated as sufficient to explain the wage transmission mechanism since it ignores the effects of other market variables (i.e., unemployment, profits) and institutional factors (i.e., unionization). Moreover, it also suffers from the point that choosing wage leaders according to the productivity growth rates as done by Eatwell, et.al. (1974) is not consistent for these countries as explained previously. 
Mitchell (1980) hypothesized a test for wage spillover from union to nonunion sectors for U.S. manufacturing industry. Mitchell (1980:375) found that heavily unionized sectors behave as wage leaders for the non-union or lightly unionized sectors. He used one year lagged union/non-union wage differential as a measure of this transmission and for the lightly unionized sector a positive and significant coefficient for this variable is obtained.

S.Vroman (1982) developed a model of wage behavior for both union and non-union workers in the U.S. manufacturing industry and run two separate wage regressions for union and non-union sectors. In order to determine the reasons of wage rate changes in the non-union sector, S.Vroman (1982:104-106) used the difference between average level of union wages and average level of non-union wages in separate equations. The positive and significant coefficients for these variables confirmed the wage leadership hypothesis whereas the differential variable in the union wage equations was found to be insignificant. Hence, S.Vroman (1982) concluded that union wage behavior influences non-union wage changes but not vice versa.

W.Vroman (1982) analyzed the relationship between wage changes in selected large collective bargainings and industry-wide changes in average hourly earnings for U.S. manufacturing industry. W.Vroman (1982:579) defined three types of wage spillovers; interindustry wage spillovers, intraindustry spillovers between union and non-union wages, intraindustry and interindustry wage spillovers between individual collective bargaining agreements. In order to test all these types of spillover, W.Wroman (1982:580) used average union wages as an independent variable together with other market and institutional variables such as the inverse of unemployment rate, the lagged percentage change in consumer price index, the change in strike activity. He found positive and significant coefficients for spillover variable in most of the industries and concluded that information on wage changes in union contracts yields valuable information about the industry-wide money wage changes. In another study, W.Vroman (1984) tested the third type of spillover. He assumed collective wage agreements in the steel and auto industries as key settlements. The significant and positive sign of this coefficient suggested that there were important spillovers from these agreements.

Plowman et al. (1986) presented an empirical model to explain the money wage changes in Australian manufacturing industry. In order to select the leading 
sectors, a factor analytic approach was used in this study. After selecting the leading sectors, the simple average of wages in these sectors, together with other market variables, the difference between vacancy and unemployment rates, rate of change in the price of tradables and the change in productivity are regressed on the change in money wages in nonleading sectors. Plowman, et.al. (1986) found that all nonleading industries follow the wage changes in the leading industries. Moreover, they carried out a Granger causality analysis in order to verify the results obtained from the regression analysis. The results of the Granger causality analysis also confirmed the wage leadership hypothesis.

Bemmels and Zaidi (1990) tested both the neoclassical market model and the wage leadership hypothesis for Canadian industry. As in Plowman et.al (1986), Bemmels and Zaidi (1990) also used factor analysis to determine wage leading sectors. In the wage leadership model, change in productivity, one year lagged value of real wage changes, expected change in prices, change in the opportunity cost of labor in terms of average money wages paid in the rest of the industries, and change in wages of each leading industry were used as indeperdent variables to explain the money wage changes in each industry. Bemmels and Zaidi (1990:557-64) found that the wage leadership variable substantially improves the fit of the model for many industries. In 16 out of 21 industries, at least one of the wage leadership coefficients was found to be significant and positive. Bemmels and Zaidi (1990:566) concluded that their results provide considerable support for the wage leadership hypothesis and the wage leadership variables have a significant influence on wages in nonleading industries after allowing for the influence of market forces. Bemmels and Zaidi (1990:564-65) also verified their results with Granger causality analysis.

Artstein and Sussman (1992) examined the market forces and spillover effects in Israeli manufacturing industry. The main argument of Artstein and Sussman (1992:970) is that wage comparison operates through institutional wage linkage as well as a wide range of informal mechanisms by which wage agreements on one industry, plant or union influence those in another even when the market conditions in which they operate are very different. Instead of choosing a leading sector, Artstein and Sussman (1992:971) used relative wages as basis of comparison and they included the change in unemployment as a main market force. Their results support the existence of an inter-industry wage mechanism. The main deficiency of their study is that Artstein and Sussman (1992) did not evaluate through which channels 
wage comparisons are made although they accepted the existence of institutional wage linkages.

Holmlund and Ohlsson (1992) investigated the intersectoral wage linkages in Sweden focusing mainly on the links between private and public sectors by using Granger causality analysis. It is found that wage changes in the private sector is the Granger cause of wage changes in the public sector. Public sector wage movements involve an error correction mechanism whereby past deviations from the long run relative wage path are offset; the lower the relative wage in the past, the higher the current wage increases (Holmlund and Ohlsson,1992:15). This means that private sector acts as wage leader for the public sector in Sweden and wage changes are transmitted from the private sector to the public sector.

Graafland and Verbruggen (1993) studied sectoral and macroeconomic influences for the wage determination process in the Netherlands between 1966-90. In order to determine wage leading sectors, Graafland and Verbruggen (1993:1375) applied modified Sims method in which both the one year and two year-lagged percentage change in wages for each sector are regressed on the percentage change in wages in the other sectors. As a result of this analysis, they found a strong support for three sectors, namely food processing, sea and air transport, and banking and insurance, being wage leaders. Moreover, some evidence for wage leadership is also found for three other sectors, the wood and building materials industry, the paper and printing industry, and the chemical industry. After finding the wage leaders, Graafland and Verbruggen (1993:1376-79) estimated sectoral equations for the wage formation in both wage leaders and wage followers. Wage formation in the wage leading sectors is found to be dominated by macro variables such as the consumer price, the macro labor productivity, and the replacement ratio defined as the ratio between the unemployment benefit and the sector wage rate. Moreover, sector specific variables such as sectoral labor productivity also have some impact on the wage formation. For the wage formation of the wage follower sectors, it is found that both the wage level in the wage leading sector and macro variables are significant. In order to detect the relative importance of macro and wage leadership variables, Graafland and Verbruggen (1993:1379) calculated reduced form coefficients of the wage equations of the sectors. Graafland and Verbruggen (1993:1381-82) concluded that the wage rate in all sectors depends more on macro variables even though wage leadership variable has some impact. Hence, they did not completely reject the wage 
leadership hypothesis but claimed that it has a secondary importance in the sectoral wage formation.

Mizala and Romaguera (1995) examined the existence of wage leadership process by public sector wages on private sector wages in the Chilean economy for the period 1976-90. They tested the hypothesis that private sector wages have followed those of the public sector by Granger causality and vector autoregression (VAR) analyses. Mizala and Romaguera (1995:304) divided their sample into two subperiods, 1976-82 and 1982-1990, with regards to centralized adjustment policies by the government. The Granger causality analysis indicated a bidirectional causality between public and private sector wages for the 1976-82 period whereas private sector wages is Granger cause of public sector wages in the period 1983-90. This means that private sector wages behave as wage leader for the public sector wages in the second period. VAR analysis consists of estimating a system of equations where each equation incorporates lags for another variable and its own history. The VAR analysis of Mizala and Romaguera (1995:305-306) indicates that in the first period private sector wages were affected by innovations in public sector wages and vice versa but for the second period each series tend to be explained by its innovations. Mizala and Romaguera (1995) concluded that for the period 1983-90 the hypothesis of public sector as a wage leader is rejected and evidence exists to support the hypothesis that private sector sets the trend for growth in nominal wages in Chile.

Erdil (1997) has performed a test of wage leadership hypothesis in Turkish manufacturing industry for the period 1975-90. In order to choose the leading sector(s) principal component factor analysis is used in this study. Following the determination of leading sectors, SUR models of both the neoclassical growth of money wages and the wage leadership are estimated for private and public sectors separately. The results have generally confirmed the wage leadership hypothesis and have drawn a picture of higher than average wage increases occurring in the leading sectors with a number of nonleading industries following their leading sectors in the next year (Erdil,1997:223).

\subsection{Concluding Remarks}

This chapter demonstrates that the reasons of wage inflation in labor markets perceived in different ways by large number of studies. In fact, most of the studies use 
the basic premises of the neoclassical theory although they criticize it severely. The institutionalist literature can be viewed as a challenge to the othodox theory of wage determination at the first instance but it is only an extension of it. Therefore, the perceived dichotomy between these two theories is not a real one.

The basic defect of the traditional neoclassical theory is its perception of labor as a commodity. The Hicksian tradition of determination of wages, like all prices, by supply and demand is a deficient approach to labor markets. Viewing the labor as an ordinary commodity brings about the ignorance of other factors. The wage determination process cannot be analyzed without considering the behavioral, social, political, and institutional forces.

Although institutionalist theory is not a real challenge to the orthodox theory in the sense that it uses the beginning assumptions of this theory, it has a significant and continuous research tradition in its own domain. Furthermore, it has an important effect in the understanding of wage inflation and has a considerable support in policy making and implementation. This section will critically discuss the shortcomings and conclusions of instiutionalist theory in general and spillover hypotheses in particular. Table 5.1 summarizes the main characteristics and findings of empirical studies on wage spillover. This table only includes the most representative and distinctive empirical studies in the literature.

First, the wage contour hypothesis offered by Dunlop (1957), assuming that similar wage determining units are linked to each other, suffers from its predictive content. How key bargain is determined is unclear. The similarities among the wage determining units are not well specified. These problems threaten the reliability of the hypothesis seriously.

Second, the relative deprivation hypothesis has problems with the definition of relative deprivation like in the case of Runciman (1966) in which his definitions of relative deprivation are very subjective.

Baxter (1973) assumes that relative deprivation exists because of perceptions of inequalities but which perceptions are transmitted to actual wage changes are not specified. Moreover, Baxter (1973) ignores the socio-economic limits on increase in wages. Another problem is related with the determination of reference group. As in the case of Hines (1969) who uses correlation coefficients to choose reference group(s), he implicitly assumes that this technique shows a causality but implementing correlation coefficient in such a way can cause researcher to reach 
misleading conclusions. Brown and Sisson (1975) use coefficient of variations and mean square deviation of earnings. However, this technique can be used for descriptive purposes but it is very naive technique to conclude on a wage imitation process. The study of Mc Carthy, et.al. (1975) has the similar problems. The problem, in fact, related with the nature of relative deprivation. The wage increases determined by relative deprivation are difficult to test against reality. This difficulty causes researchers to apply indirect tests and they try to rationalize the data in terms of theory.

The morale effect hypothesis, concerning with the regularities in the labor markets, takes into account the labor turnover costs to employer and costs accrued by quitting to employees (Behman,1964). It is a demand-pull wage determination model and most of the study is in the Hicksian tradition. Spillover effect is only observed when the labor market experiences major supply and demand fluctuations. Only the quit rate as a behavioral variable explains the growth in wages and spillovers. Although Behman (1964) claims that the study analyzes the role of institutions in the framework of market mechanism, the labor market institutions are given a secondary and insignificant role in the wage determination.

The union politics hypothesis is clearly in the tradition of institutionalist analysis of wage inflation. The main deficiency of all the studies is related with the verification of hypothesis with the empirical models. The use of statistical and econometric methods are not observed since the hypothesis concerns with purely behavioral and political factors and the policy mechanisms inside the trade union are not suitable for the use of such techniques. This brings another problem; the hypothesis ignores the market conditions. Flanagan (1976) claims that the source of such ignorance by the hypothesis is the trade union itself; for political reasons unions ignore the market conditions in shaping their wage demands. Flanagan (1976) and Freeman (1980) use econometric techniques in their studies to show there is a spillover from union to non-union sectors but it is not clear that this spillover is a result of union politics. It may well be the result of the threat effect. 

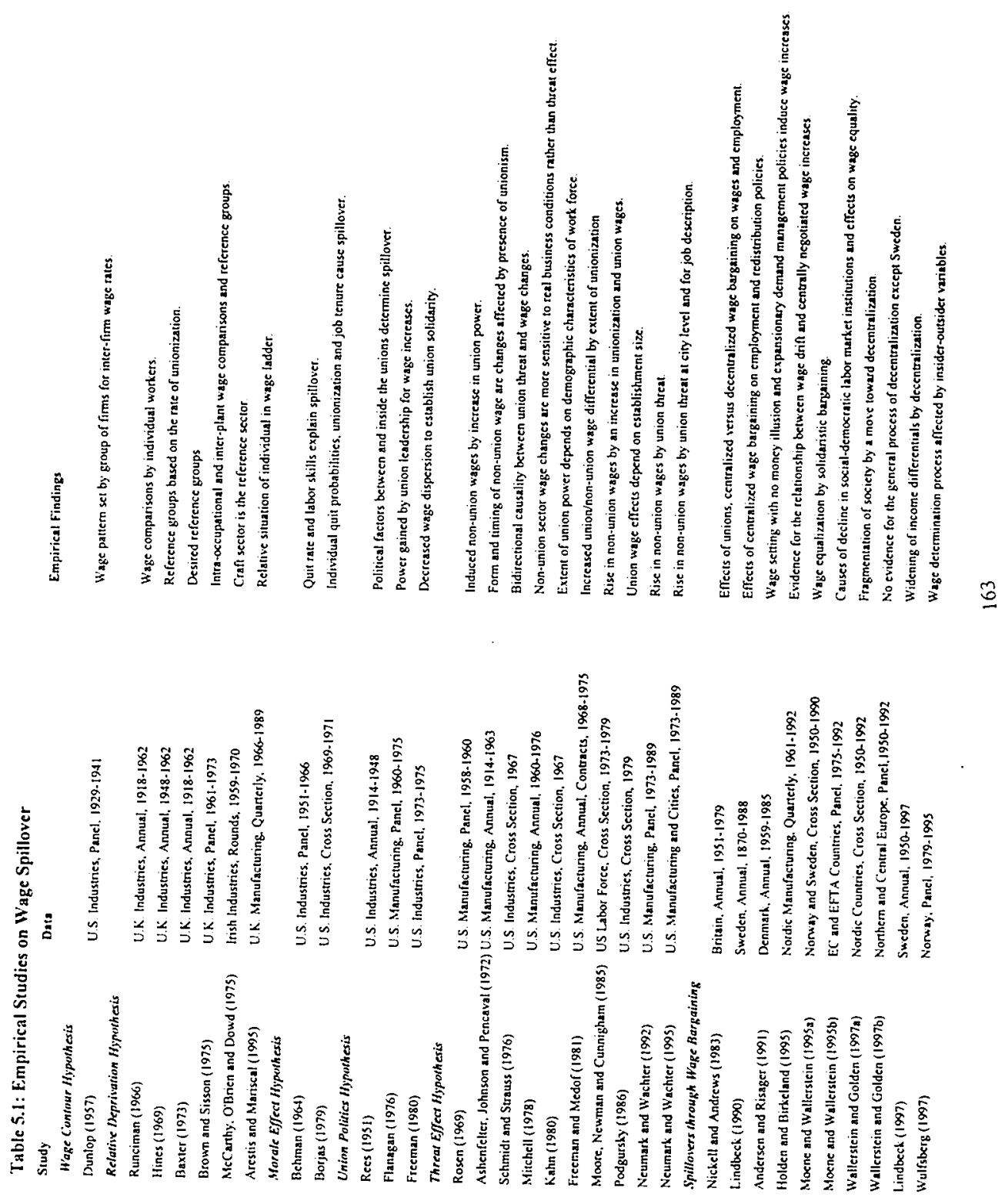


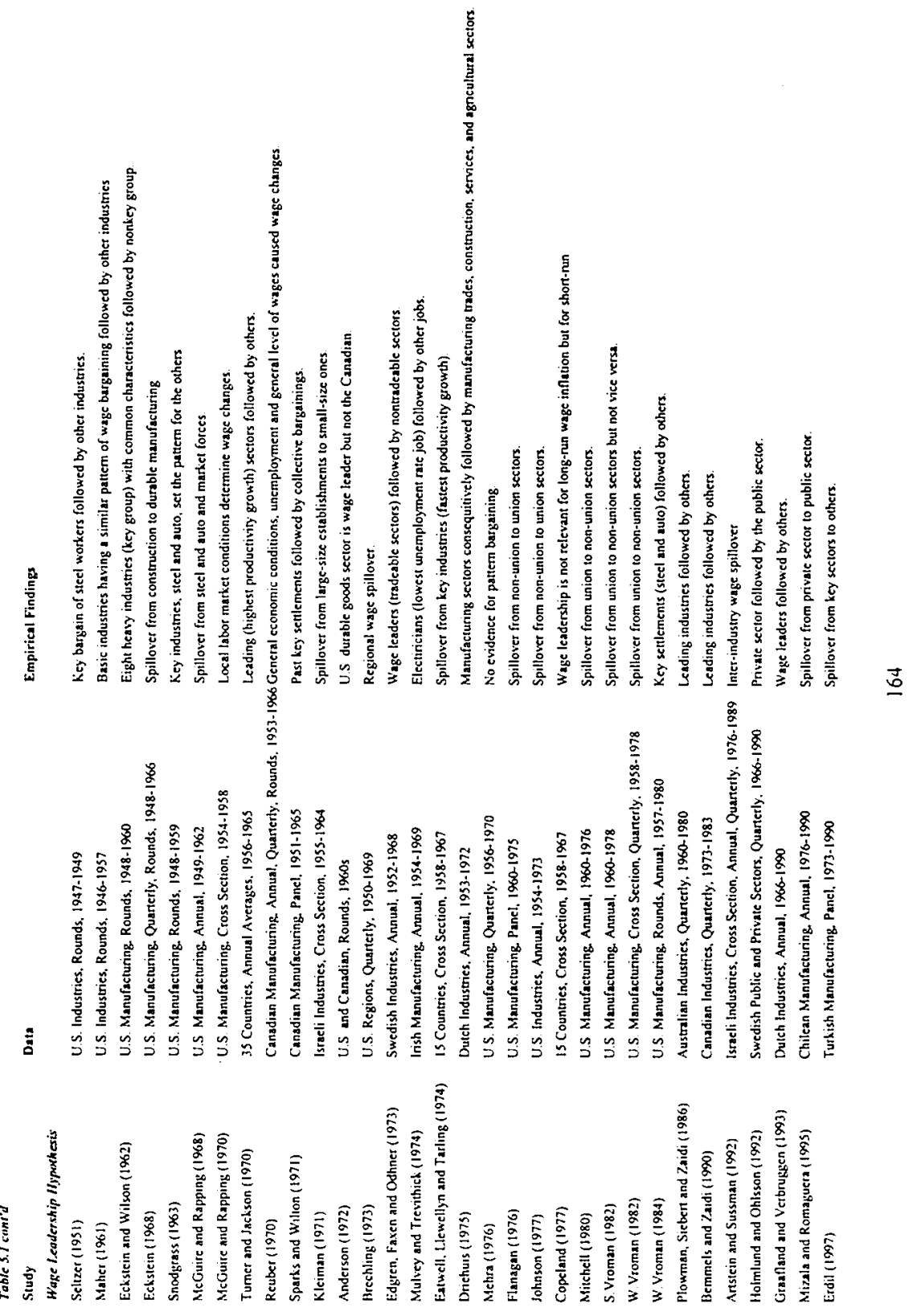


Threat effect hypothesis, as an explanation of wage spillover from union to non-union sector, is one of the consistent theories of wage inflation when compared with the previously criticized hypotheses. The first empirical model testing this hypothesis is offered by Rosen (1969). Rosen (1969) offers probabilistic statements for the increase in union power and use it as an explanatory variable. The problem related with this study is that union power variable is not an exogenous variable. It should be endogenous since increase in union power causes wage inflation and resulting wage inflation and some other factors then determine the union power. Moreover, the probabilistic structure is not explained correctly. For consistency, probability of unionization should be treated as a function of both returns to union entry and costs of entry. Furthermore, the net of costs and returns for the present members affect the decisions of potential members. Although Ashenfelter, et.al. (1972) claims that presence of unionism affects the timing of wage changes, they do not carry out a test of this proposition in a dynamic setting. Schimidt and Strauss (1976) find a unidirectional causality between unions and earnings but it may be misleading to propose such a strong proposition only by using a cross section data set for a one-year change in earnings. Mitchell (1978) supports the lack of effectiveness of demand management in the inflation process. However, as Mithchell (1978) found a low coefficient of unemployment term and a high value on lagged prices does not imply an inflation process that will not respond to the level of aggregate demand. Moreover, the question whether the coefficients governing the wage-price process would change if a permanent change in policy behavior could achieve credibility is unanswered. Using a cross-section data set Kahn (1980) found that the extent of union power differs with respect to race-sex groups. The major problem in this study is that Kahn (1980) assumes unionization rate as exogenous but he claimed that it should be treated in a simultaneous equation setting. However, it is not always possible to estimate simultaneous equation system because of the data problem. The study of Freeman and Medoff (1981), using 2-digit Standard Industrial Classification (SIC), suffers from an important aggregation bias in two points. First, spillovers should be searched for sectors as detailed as possible. Second, especially aggregating wage data for 2-digit SIC may cause problems. Moore et.al. (1985:24) define elasticity of demand for the output of the unionized firms by using the ratio of the output of unionized firms to the output of nonunion firms in the same industry. However, they approximate this as the ratio of union to nonunion employment in an industry (Moore 
et.al.,1985:24). The problem is that how output is approximated by employment and under which assumptions such an approximation is true are not clear in this study. Podgurky's study (1986) has also a data problem. He claimed that union wage effects depend on establishment size but this should be supported by time series data or the estimation procedure should be repeated by cross section data for another year(s). On the other hand, studies of Neumark and Wachter (1992 and 1995) do not have same problem since they use a panel data set. Theoretically, they propose that there should be spillovers between the union and nonunion wages in the same industry because of threat effects (Neumark and Wachter, 1992:7). However, it is possible to observe threat effects between related industries. Another problem is related with the definition of employment shares, employment shares are defined as percent of total economy employment (Neumark and Wachter,1992:7) but why such a definition is used instead of shares as percent of industry employment is not explained. In general, most of the studies in threat effect hypothesis, especially the early ones, ignore the labor supply effects of relative wage changes.

The empirical results of wage spillovers through bargaining are discussed in the context of Nordic countries, except the British case of Nickell and Andrews (1983), since these countries have a long tradition of various types of wage bargaining and there is a vast literature on the practises of wage setting in Nordic countries. ${ }^{27}$ Nickell and Andrews (1983) conclude that unions in a decentralized economy have significant employment effects. Furthermore, unions have damaging effect on employment and this effect can be prevented by bargaining of unions and employers concurrently on employment and wages.

Andersen and Risager (1991) estimate a wage-employment model for the manufacturing sector of Denmark. They found that wages do not respond sufficiently to the state of the labor market since unemployment in their model put forth little pressure on wages (Andersen and Risager, 1991:575). Andersen and Risager (1991) further find out that shorter working hours lead in the long run to full wage compensation and a fall in total number of hours worked, and expansionary demand management policies stimulate wage increases which ultimately eliminate the expansionary effects on activity.

27 Only a summary of literature survey is analyzed here and presented in Table 5.1. 
Holden and Birkeland (1995) claim that the large part of increase in money wages is the result of negotiations at firm level and this wage drift may offset the outcome of the central agreement. Their study presented evidence for Denmark, Finland, Norway, and Sweden, suggesting that there is no or very little such offsetting effect. Moreover, the institutional system of wage setting may induce nominal rigidities at the central negotiations that may prevent wage restraint in times of low inflation and low productivity growth (Holden and Birkeland, 1995:18).

Moene and Wallerstein (1995a) discuss the politics of solidaristic bargaining. Solidaristic bargaining called for the equalization of workers' pre-tax income by eliminating or reducing wage differentials that existed between plants within the same industry, between industries, between regions, and ultimately between occupations (Moene and Wallerstein, 1995a:79). Moene and Wallerstein (1995a:92) find that wage equalization generates an industrial structure with more investment in modern plants and more rapid abandonment of older plants than would otherwise exist when solidaristic bargaining does not raise the wage far above the market-clearing level. The outcome is greater output per worker without reductions in employment. Therefore, the unions' search for greater wage equality found support in employers' pursuit of higher profits (ibid., 92).

Moene and Wallerstein (1995b) present a dissenting view of the economic effects of social democratic policies and institutions in the labor market and discussion of corporatism, trade dependence, and the origins of centralized wage bargaining. Moreover, their study examines the politics and economics of the reduction of wage differentials through solidaristic bargaining. Moene and Wallerstein (1995b) find out that, nowadays, there is a tendency toward less centralized bargaining, growing wage differentials, and higher equilibrium unemployment throughout North and Central Europe. However, they claim that the legacy of social democracy in terms of a relatively egalitarian income distribution may be long lasting in Nordic countries at least in comparison to other societies (Moene and Wallerstein, 1995b:210).

Wallerstein and Golden (1997a) present data on the changes in the centralization of wage bargaining and measures of the centralization of wage setting in Sweden, Norway, Finland, and Denmark since 1950. The main finding of the study is the diversity of national experiences and the absence of strong evidence of a common trend in Nordic countries. Wallerstein and Golden (1997a) claim that 
adjustments in the distribution of wages and benefits do not necessitate the abandonment of centralized bargaining. Furthermore, whether employers and unions are willing to cooperate in modifying the central agreement to accommodate changes in technology and in market conditions depends on the political relationships that exist within and between the unions and employers' confederations (Wallerstein and Golden, 1997a: 727).

Wallerstein and Golden (1997b) submit the data on changes in organization of unions, employers' associations, and collective bargaining in Austria, Belgium, Denmark, Finland, Germany, the Netherlands, Norway, and Sweden from 1950 through 1992. Additionally, they put forward the indicators of the strength of the unions' position in the market, union concentration, statutory authority of both the union and employers' association, dimensions of statutory authority, and the centralization of private sector wage setting. Wallerstein and Golden (1997b) test whether the changes in patterns of wage setting in private sector are consistent with the claim that corporatist bargaining institutions are being undermined by changes in global economy. Although Wallerstein and Golden (1997b:379) find some signs that corporatist wage-setting institutions are in decline, they also find offsetting signs of the resiliency of such institutions. In general, the existing evidence does not point out that wage-setting in the private sector is enduring a general process of decentralization in these eight countries.

Lindbeck (1997) examines the economic and social experiments made in Sweden after World War II and presents the characteristic features of the institutional structure. Lindbeck (1997) observes that, in the early 1970s, unions succeeded in pushing through important labor market legislation in their favor when they could not get what they wanted through centralized bargaining with employers. However, the deterioration in the relations between the unions and the employers' associations was accentuated by an ideological offensive as employers shifted to a more free market oriented position in the early 1980s. Lindbeck (1997) concludes that the common characterization of Sweden as a country of strong consensus among unions, employers' associations, and the government does not really seem to be an appropriate description of the dominant power relations in Sweden, particularly since the mid1970s.

Wulfsberg (1997) investigates wage determination in Norwegian industry using as panel of over 7,000 firms over 17 years. The wage equations focus on 
relative importance of insider versus outsider variables. Wulfsberg (1997) finds out that insider and outsider variables are relatively more important than other variables employed in the determination of wages in Norwegian industry.

Finally, some studies on the wage leadership hypothesis will be criticized. ${ }^{28}$ The wage leadership hypothesis is the most consistent hypothesis in the literature with its assumptions on the transmission of wage changes from one industry to another. Moreover, there is a vast empirical literature verifying the existence of wage leadership and most of the studies statistically test the hypothesis in some extent. One of the first important studies is carried out by Eckstein and Wilson (1962). As most of the studies of this literature, Eckstein and Wilson's study (1962) has an important shortcoming: the leading sector(s) are chosen on ad hoc basis and this problem causes that models cannot be tested for other time periods and geographical area reliably. This is a very important weakness of Eckstein and Wilson (1962). Secondly, which bargain is assumed to be the key bargain is not well defined. Eckstein (1968) compares new results with that of the previous study and finds a new spillover channel.

McGuire and Rapping (1966, 1968, and 1970) choose leading sectors on $a$ priori grounds and they do not consider a significant spillover channel from union to nonunion sectors in formulating their models by noting "...spillover variable may not be relevant in the nonunion sector..." (McGuire and Rapping,1968:1031). Moreover, McGuire and Rapping (1968:1019) define key bargain wage as a geometric mean of the equilibrium wage rate, such a definition overestimates the key wage rate and this cause their study to reach a conclusion that there are no significant spillovers and to prefer market model against wage leadership model. Hence, the results concluded in these studies should be interpreted cautiously.

Turner and Jackson (1970) choose highest productivity growth sectors as the leading ones and conclude that other sectors follow them. However, the main shortcoming is related with the statistical method they use. Although Turner and Jackson (1970) do not have the data on labor productivity growth, they use wage

\footnotetext{
${ }^{28}$ Not all the studies on wage leadership hypothesis will be discussed here since the details are given in the previous section and the types of the shortcomings in these studies can be seen in Table 5.1. The most significant ones for the rest of study will be analyzed critically.
} 
changes as an approximation for labor productivity growth and employ the dispersion of wages with a number of normative assumptions. ${ }^{29}$

The model proposed by Edgren et.al. (1969 and 1973) cannot provide a general theory of wage leadership in the sense that it is only applicable to the cases of small open economies. Nordhaus (1972) states that this model cannot be applied countries like France, Germany and United States. Moreover, the model works under the assumption of fixed exchange rate system and the main premises of the model are not true under flexible exchange rate system. Finally, the empirical performance of the model relies on the descriptive statistics.

The study of Eatwell et.al. (1974) also suffers from the shortcomings related with the determination of wage leading industries since they use again productivity growth as a criteria to choose key sectors. Moreover, the effects of some institutional variables such as unionization on wage spillover are not considered.

Driheuis (1975) assumes the Dutch manufacturing industry as the wage leader for the rest of economy. However, first such an approach has the aggregation problems and second manufacturing industry is chosen as the wage leader on ad hoc basis. Moreover, Driehuis (1975) uses contract wages instead of wage sum per worker and assumes that only key wage bargains spillovers from manufacturing to other sectors. On the other hand, Driehuis (1975) also finds that trade unions do not play a significant role in the wage determination in services and agricultural sectors. In this context, using wage sum may be more appropriate. Although Driehuis (1975) has these shortcomings, it gives valuable evidences for my study. When formulating the Dutch part of my study, the main emphasis is given to manufacturing industry and in a different way searching for the wage spillovers inside the manufacturing industry.

Two other studies, Plowman et al. (1986) and Bemmels and Zaidi(1990), give me important methodological insights. In these studies, factor analytic approach is used to find the leading sectors. It is a substantial methodological improvement indeed. However, the important shortcoming of these studies is that this approach is sensitive to the outliers in the data set. Another problem is related with the price expectations, both studies assume that price expectations of employers and employees

\footnotetext{
${ }^{29}$ For a more detailed discussion of the model proposed by Turner and Jackson (1970), see Knight and Mabro (1972).
} 
are same. Moreover, a variable called alternative wage set is used but the exact definition of this variable is not provided.

Graffland and Verbruggen (1993) offered a new and more reliable method, Modified Sims method, to determine wage leading sector(s) as an alternative to the factor analytic approach. This method will be used in my study because of the advantages it poses. Their analysis confined to both sectoral and macro wage equations and it is one of the important studies on the wage leadership in the Netherlands.

Erdil (1997) uses factor analysis to determine wage-leading sector(s) in Turkish manufacturing industry. The method is changed because of shortcomings of factor analysis. It has also some data problems because of the availability of the data. However, it is a first attempt to test wage leadership hypothesis for Turkish manufacturing industry and the wage inflation models used in Erdil (1997) are employed in this study with some alterations.

The final observation from Table 5.1 is related with the countries in the data column. There are few European studies on wage spillovers. The research on wage spillovers first started in United States and it is seen that, for example, relative deprivation hypothesis is tested only for United Kingdom. For other European countries, the serious effort begin in 1970s and increase in number after this date but most of the studies are concentrated on few countries, like Ireland, the Netherlands, and Scandinavian countries. The cross-country studies have also shortcomings of the data availability and this causes models to employ inappropriate proxies.

In conclusion, all studies have some shortcomings but this is the nature of the science of economics. It is not possible to model real life exactly. What determines a model is more successful relative to others is how vital the shortcomings are. 


\section{MODELS OF WAGE INFLATION}

\subsection{Introduction}

In this part of the study, three versions of wage inflation models will be formulated. First, a bargaining model of wage inflation proposed by Nickell and Wadhwani (1990), Layard et al. (1991), Nickell et al. (1994), and Lever and Marquering (1995) is presented. Second, a market model which also includes some bargaining elements is discussed. The relation between these two sections is that the first section gives necessary clues on how to introduce bargaining elements into other models and estimating equations. Finally, by employing the basic premises of these models, a wage leadership formulation as a representative version of spillover models of wage inflation is obtained. The models discussed here should not be considered as antagonist to each other rather they might be treated as complements to one another. The aim of all these discussions is to formulate a model that can be estimated in the next chapter.

\subsection{General Properties of the Bargaining Models}

Nickell and Wadhwani (1990), Layard et al. (1991), Nickell et al. (1994), and Lever and Marquering (1995) hypothesized that wages are settled through bargaining between firms and unions. On the other hand, employment is determined by firms to maximize its profits. It is also assumed that unions seek to maximize the expected income of their members. ${ }^{30}$

The firms are assumed to have the following Cobb-Douglas production function. $^{31}$

(6.1) $Y_{1}=N_{1}^{a} K_{1}^{1-a} \quad 0 \cdots \alpha \cdot I$

where $Y$ denotes for production in terms of value added, $N$ for employment that shows labor intensity and $K$ is the capital stock. The index $i$ points to industry. The product

\footnotetext{
${ }^{30}$ This section is generally based on Layard et al. (1991).

"1) Cobb-Douglas production function is used instead of a Constant Elasticity of Substitution (CES) production function since the results obtained do not change but the derivation becomes more tedious. For the discussion of this point, see Layard et al. (1991:102-107).
} 
demand is determined by a demand index, the price of value added, and the price elasticity of demand ${ }^{32}$ Thus, the demand function is

(6.2) $Y_{1} \ldots P_{t}^{*} \cdot \beta_{1} Y_{d t}, \varepsilon_{1} \cdot l$

where $P_{1}$ is the real price of value added, $\varepsilon_{i}$ stands for the price elasticity of demand, $\beta_{t}$ is a non-negative random variable for the demand uncertainty, and $Y_{d}$ represents an index for demand. The size of the random variable and therefore the volume of demand can be determined and finalized after the bargaining process. Price, the level of production, and the employment are determined following the wage negotiations. By using the production and demand functions, the profit function of the firm can be written as

(6.3) $\Pi_{1}=R\left(N_{1}\right)-N_{1} W_{1}$

where $R$ is revenue and $W$, symbolizes wages

By substituting equations (6.1) and (6.2), the profit function can be rewritten as

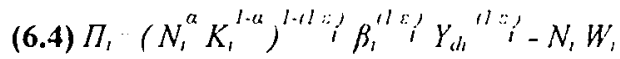

The employment is determined by maximization of profit function when the first order condition is set equal to zero.

(6.5a) $\delta \Pi_{1} \delta N_{1}=0$

Consequently, the optimal level of employment is found as

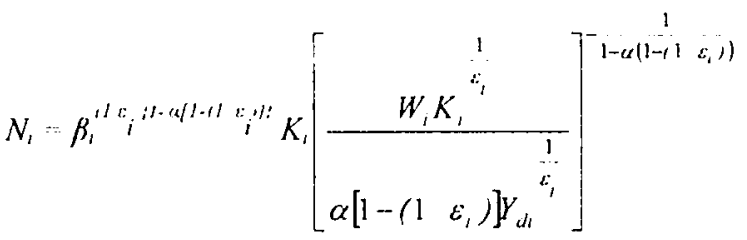

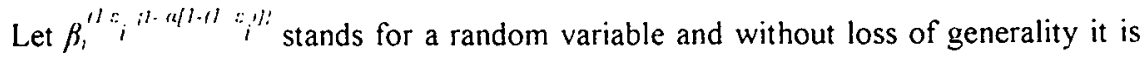
assumed that it has a mean value of unity, and further $\rho_{1} \cdot \mid 1-(1 ;) /$ where $0 \cdot \rho_{1} \leq 1$, then $\rho$, may be treated as an indicator of competition in the product market. In the case of perfect competition $\rho_{i}$ will be equal to 1 or under the monopoly situation it will be .close to zero.

\footnotetext{
$\therefore$ The production function can be written by taking account of a productivity factor to consider the effects of technical progress (Lever and Marquering, 1995:10). However, it is found that we end up with the same wage equation. Therefore. such a factor is not included for the sake of simplicity.
} 
If we substitute the equation (6.5b) into equation (6.4), it is found that maximum profits are proportional to labor costs.

(6.6) $\left.\Pi_{t} \cdot /(I-\alpha y)\right) \quad\left(4 p_{l} / W_{1} N_{1}\right.$

Trade unions maximize the expected income of the representative member. The utility function of trade unions for the $i^{\text {th }}$ industry can be written as (6.7) $U, \quad(, W,(1-Q) W A$, where $Q_{1}$ is the probability of being employed within the same industry in the following period, $W$, represents the wage within the industry under consideration, $W A$ stands for the wage rate expected for a worker made redundant or an alternative wage. When the bargaining is resulted with a disagreement, employees may go for a strike. When they are in strike, suppose workers receive wages $\bar{V}_{1}$. For the sake of simplicity, assume that these wages are equal to alternative wages $W A$. Hence, ${ }^{33}$

(6.8) $\left(l_{1}-\bar{l}_{1} \quad()_{1},\left(W_{1}-W A\right)\right.$

On the other hand, the firms' profit during the strike exhausted, that is

(6.9) $\bar{\Pi}_{i} \quad 0$

The optimum result of the negotiations can be derived by maximizing the following Nash function.

(6.10a) $\Theta=\left(\left(I_{1}-\left(I_{l}\right)^{\prime}\left(\Pi_{1}-\bar{\Pi}_{1}\right)\right.\right.$

where $\eta_{1}$ refers to the bargaining power of the unions in the $i^{\text {ih }}$ sector and $\eta_{1} \cdots 0$. In other way, the maximization problem can also be written as by making the necessary substitutions given in equations (6.8) and (6.9).

(6.10b) $\max \Theta=Q\left(W_{1}\right)^{\prime \prime}\left(W_{1}-W A\right)^{\prime \prime} \Pi_{1}\left(W_{l}\right)$ ${ }_{i}$

From the first-order condition of this maximization problem, it is found that

(6.11) $1-\frac{W A}{W_{i}}=\frac{1}{\eta_{p w^{\prime}}+\frac{\alpha \rho_{1}}{\gamma_{1}\left(1-\alpha \rho_{1}\right)}}$

where $\eta_{p w}-(\delta Q \delta W)(W, Q)$ can be defined as the absolute elasticity of survival with respect to the wage rate (Layard et al., 1991:104). By same way, from equation $\mathbf{6 . 5 b}$, it is possible to find that $\eta_{p w} \cdots \eta_{p n}\left(1-\alpha p_{l}\right)$ where $\eta_{p n} \cdots-\left(\delta Q \delta N_{\nu}\right)\left(N_{l} Q\right)$ which is

\footnotetext{
${ }^{3}$ Here $P$ is a function of wages, that is, $P_{1}-P(W)$.
} 
the employment elasticity of survival (ibid.: 105) ${ }^{3.4}$ Substituting the expression for $\eta_{p w}$ into equation 6.11 produces

(6.12) $1-\frac{W A}{W_{1}}=\frac{1-\alpha \rho_{1}}{\eta_{m}\left(W_{1}\right)+\frac{\alpha \rho_{!}}{\gamma_{1}}}$

Alternative wage is composed of

(6.13) $W A: / 1-\psi\left((l),(I) / W_{o} \cdot \psi /(l, \dot{l})\left(U_{h}\right.\right.$

where $0 \quad \psi^{\prime} \quad l, \psi_{1} \quad 0, \psi_{2} \quad 0, W_{0}$ is the wage rate outside the $i^{i^{t h}}$ industry, $U_{b}$ stands for unemployment benefit $\psi(I \%$ (i) shows the probability that an employee made redundant does not find employment elsewhere, $U$ is the unemployment rate and $\dot{U}$ symbolizes the change in short-term unemployment rate. The common sense tells that the probability of not finding a job of an unemployed worker will inrease if both unemployment and short-term unemployment rises.

Substituting 6.13 into 6.12 gives

(6.14) $1-\frac{W_{o}}{W_{1}}\left[1-\psi(U, \dot{l})\left(J-\left(U, W_{n}\right)\right]=\frac{1-\alpha \rho_{1}}{\eta p_{n}\left(W_{1}\right)+\alpha \rho_{1} \gamma_{1}}\right.$

In order to obtain the impact of the explanatory variables on the wages in the $i^{i \text { th }}$ sector, we totally differentiate the first-order condition by denoting logarithms of

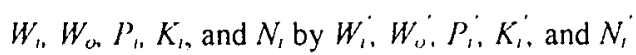
(6.15) $d W_{i}^{\prime} i / d P_{i}^{\prime} \cdot(1-\alpha)\left(d K_{i}^{\prime}-d N_{1}^{\prime}\right) /(1-i) / d W_{o}^{\prime} \cdot \theta_{1}\left(d l / h d W_{o}^{\prime}\right) \cdot \theta_{2} d I I$ $\theta_{s} d i l l \cdot \theta_{+} d p \theta_{i} \cdot \theta_{s} d y$

Here, it can be shown that $0 ;, \quad 1,0_{1} \quad 0,0_{2} \quad 0,0_{3}, 0_{1} \theta_{3}, 0$ and the sign of $\theta_{4}$ is indeterminate. ${ }^{35}$ Equation (6.15) is a way of writing sectoral wages as a log-linear of internal and external factors, product market power, and union bargaining power and this equation also reveals that the weight of the internal factors $(i)$ and that of the external factors ( $I-i$ ) sum up to unity (Lever and Marquering, 1995:13). In fact, this equation validates that it is possible to write the sectoral wages as a log linear of internal and external forces, product market and union bargaining power. As common sense tells unemployment benefits and bargaining power exert a positive pressure on the wage rate whereas the unemployment rate and the change in short-term

\footnotetext{
$\therefore$ The derivative of survival function is positive as shown by Layard et al. (1991:537).

$\therefore$ For the complete derivations of these multipliers, see Lever and Marquering (1995:13-14).
} 
unemployment put forth negative impacts in determining the wage rate. However, the effect of product market power cannot be determined. ${ }^{36}$

This model brings important insights for the derivation of two other models in what follows. Both of them include some bargaining elements. The first one is concentrated on the impacts of market variables the other is on the effects of wage imitation behavior. In sum, these models may be considered as simplifications and/or extensions of the above complete bargaining model.

\subsection{A Typical Bargaining Model of Wage Inflation}

The bargaining model used in this study has a close resemblance with the model which is derived in the previous section and inspired from the models proposed by Addison and Burton (1979), Plowman et al. (1986), and Bemmels and Zaidi (1990).

In order to derive the model, assuming that all firms in an industry have the same Cobb-Douglas production function ${ }^{37}$, the rate of growth of labor demand in an industry $\left(\dot{L}^{d}{ }^{\prime}\right)$ is written as ${ }^{38}$

(6.16) $\dot{L}^{d}{ }^{\prime}-\dot{v}_{\|}-\dot{w}{ }_{11}$

where $\dot{v}_{\|}$is the value added in sector $i \dot{w}_{\|}$is the level of real wages in the $i^{\text {th }}$ sector.

Moreover, labor supply to any sector is a multiplicative function of its real wage and those in alternative occupations. Then, the sectoral labor supply function can be written as

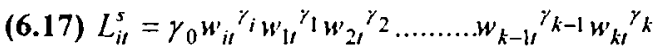

where $\gamma_{1}$ is a parameter that summarizes the effect of all other aspects of net advantages on the labor supply decision and it is assumed to be held constant and $y_{1} \cdot 1$. Then let us define $\mathrm{W}_{\mathrm{a}}(\mathrm{a}=1, \ldots, \mathrm{k})$ as the alternative wage set that is the wages

\footnotetext{
${ }^{36}$ Layard et al. (1991), Nickell et al. (1992), and Lever and Marquering (1995) speculate that the degree of competition in the product market exerts a negative pressure on the wage rate by assuming the positive survival effect as negligible.

${ }^{37}$ We have certain simplifying assumptions in this section like that both production functions and labor supply functions are Cobb-Douglas type in order to strip off the analysis of the problem to its most basic essentials. The homogeneity restrictions are met by both CobbDouglas and Constant Elasticity of Substitution type of functions (Addison and Burton, 1979:95)

${ }^{38}$ The dot operator indicates, hereinafter, the term is a proportional rate of change.
} 
in alternative occupations. Taking the logarithmic time derivative of equation (6.17), an equation determining the rate of growth of labor supply to $i^{\text {th }}$ sector is found as

(6.18) $\dot{I}_{t}^{s}=\gamma_{1} \dot{w}_{u}+\sum_{a=1}^{k} \gamma_{a} \dot{v}_{u}$ where $\gamma_{a} 0$.

By equating (6.16) and (6.18), the market equilibrium growth rates of real wages in the $i^{\text {th }}$ sector is found as

(6.19) $\dot{w}^{*}{ }^{*}=\beta_{0} \dot{v}_{u}+\sum_{u=1}^{k} \beta_{u} w_{u}$ where $\beta_{0}=l\left(I \cdot \gamma_{1}\right) \quad 0$ and $\beta_{a} \cdot-\gamma_{a}\left(I \cdot \gamma_{0}\right) \quad 0$.

We further assume that markets do not clear instantaneously. In other words, during a given period only a fraction of $\theta$ of the difference between the current equilibrium rate of growth of the $i^{\text {th }}$ real wage $i_{i l}{ }^{c}$ and the past period's actual growth rate $\dot{w}_{n-1}$ is made up

(6.20) $i_{11}-i_{i r-1}=\theta\left(i_{i t}^{, k}-i_{i t-1}\right)$

where $0 \cdot \theta \cdot 1$.

By substituting (6.19) into (6.20), it is found that

(6.21) $\dot{i}^{\prime \prime}=\varepsilon+\pi{ }_{n}+\sum_{i=1}^{k} \phi_{a} i{ }_{u t}+\rho \dot{i}^{i_{t-1}}$

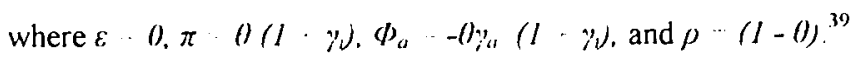

Then, we further assume that all individuals are without money illusion that is expected rate of inflation equals to the actual rate of inflation. Thus, it may be possible to add the current expected rate of growth of the price level to both sides of the equation $(6.21)^{+10}$

(6.22) $\dot{W}_{u}=\varepsilon+\pi \dot{i}_{n}+\sum_{a=1}^{k} \phi_{u} \dot{i}_{u}+\rho i_{n-1}+\lambda \dot{P}_{i}$

\footnotetext{
"Here $\theta \pi$ land $0 \quad \rho \quad l$.

H" Therefore, in this equation $i$ is assumed to be equal to unity since agents are without money illusion.
} 
What is implicitly assumed in equation (6.22) is that both employers and employees have the same sort of price expectations. Finally, we add the inverse of the probability of being unemployed to the equation (6.22). Thus, we have ${ }^{41}$

(6.23) $\dot{W}_{t t}=\varepsilon+\pi \dot{v}_{n}+\sum_{a=1}^{k} \phi_{a} \dot{w}_{a t}+\rho \dot{w}_{t t-1}+\lambda \dot{P}_{t}+\sigma U_{t}^{-1}$

In the next section, we will add the sectoral wage imitation behavior to the model given in (6.23). Therefore, we will add another significant component of wage determination in the bargaining process. The resulting model, then, can be named as the wage leadership model.

\subsection{The Wage Leadership Model}

We will first give a brief outline of the wage leadership model before introducing how the presence of such behavior is examined. Following Addison and Burton (1977), we postulate that nominal wage changes are mainly transmitted from one sector of the labor market to another not merely by a market mechanism but by a spillover mechanism. This mechanism has the following common form:

(6.24) $\dot{W}_{t}=\sum_{s=0}^{h} \sum_{r=1}^{k} l_{t r, t-s} \dot{W}_{r, r-s}, \forall i=l, \ldots, n ; k=l, \ldots, n(i=k, s=0)$ and $l_{i r, t-s} \geq 0$.

In (6.24), $\dot{W}$, is the proportional rate of money wage increase in the $i^{t h}$ sector; $\dot{W}_{r}$ is the proportional rate of change of money wage increase in the reference sector(s); $l_{\text {rr.t-s }}$ stands for the a coefficient stating the magnitude of the spillover effect of the rate of $r^{t h t}$ sector wage change in the period $t-s$ on the current rate of $i^{\text {th }}$ sector wage change; $\mathrm{k}$ stands for key sectors; $s$ and $t$ are time subscripts; and finally $h$ is the time horizon of the spillover system.

The relation given in (6.24) can also be expressed in matrix notation; the array of spillover coefficients include what Tobin (1972) has termed the wage pattern matrix of the spillover system. The wage leadership hypothesis assumes that reference wage sets are neither large nor variable across the labor market; all wage comparisons are supposed to be made with respect to one singular leading sector or selected key group of mutual leading sectors so that only $I^{\text {th }}$ column or $L$ columns $(I,=I, \ldots, r)$ of

\footnotetext{
${ }^{+1}$ In this equation $\mathrm{U}_{t}^{-1}=\mathrm{f}\left(\bar{W}_{t}\right)$ where $\bar{W}_{t}$ is the reservation wage below which the workers prefer to be unemployed (Bemmels and Zaidi, 1990).
} 
the wage pattern matrix contain nonzero elements (Burton and Addison, 1977:336). In such a situation, (6.24) can be rewritten as

(6.25) $\dot{W}_{u}=\sum_{s=0}^{h} l_{t l . t-s} \dot{W}_{t . t-s} \quad, i \cdot I$. and $l_{t t . l \cdot s} \cdot 0$

In other words, $(6.25)$ can be rewritten by using key group wages as

(6.26) $\dot{W}_{n}=\sum_{s=0}^{h} l_{k, t-s} \dot{W}_{K \cdot t-s} \quad, i: K$ and $l_{i k \cdot t-s} \quad 0$

where

$$
\dot{W}_{k, t-s}=f\left(\dot{W}_{l, t-s}\right) \quad, L=1, \ldots, r
$$

where $f$ denotes the operation like mean, median whereby the index of the rate of wage inflation in the key group $\dot{W}_{K}$ is arrived at by participants of the nonkey sectors (ibid, 337).

It is possible to formulate and test the wage leadership hypothesis in several steps:

- determining the leading sector(s),

- formulating and estimating a system of equations.

- testing wage spillovers.

- identifying the determinants of wage leading-following behavior.

The first step to test the wage leadership hypothesis is to determine the leading sector(s). In the literature, most of the studies chose the leading sector on a priori base, i.e. Eckstein and Wilson (1962), McGuire and Rapping (1966, 1968, 1970), Reuber (1970), and Driehuis (1975). Sometimes, certain criteria are used by some other studies in choosing the leading sectors. Edgren et al. (1973), for instance, used the tradable export-oriented sectors and Eatwell et.al (1974) applied the fastest productivity growth measure. Rarely, statistical methods such as testing the covariance structure and factor analytic approach are employed; Mehra (1976), Plowman et.al. (1986), and Bemmels and Zaidi (1990) are the exceptions. All of the above methods to chose the leading sector(s) have some sort of deficiencies as explained in the previous chapter. Graafland and Verbruggen (1993) applied modified Sims' method in which both the one-year and two year-lagged percentage change in wages for each sector are regressed on the percentage change in wages in the other sectors 
In this study, we will make use of a somewhat different method to determine the wage leading sector(s) and employ wage leads in the model in addition to lagged wages. This model will, in fact, be a causality analysis and details of the procedure are explained in the appendix.

In order to choose the leading sectors, the following equation will be estimated by OLS for each sector in the economy. ${ }^{42}$

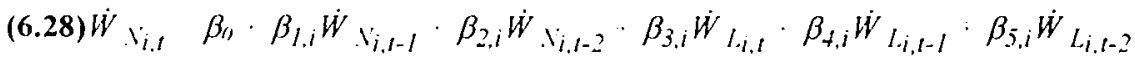

$$
\begin{aligned}
& \beta_{6, i} \dot{W}_{l, i, t \cdot 1} \cdot \beta_{7, i} \dot{W}_{L, i, t \cdot 2} \cdot u_{t}
\end{aligned}
$$

where i stands for industry, f for lime, and

$W_{l} \Rightarrow$ the percentage change in the hourly wage rate of the leading sectors.

$W_{N} \Rightarrow$ the percenage change in the hourly wage rate of the following sectors. and

${ }_{t} \Rightarrow$ the independently. identically distributed disturbance term with $N\left(0 . \sigma^{2}\right)$.

Then, the hypothesis of $\beta_{6} \cdot \beta_{7} \quad 0$ will be tested by the Wald statistics given in equation (A.14). When the estimates of $\beta_{6} \cdot \beta_{7} \cdot 0$, this means that changes in $I^{\text {th }}$ sector wages do not cause changes in $N^{\text {th }}$ sector wages. Hence, wages in sector $N$ could be leading to the wages in sector $I$.

After the determination of the leading sector(s), the second step is to estimate a system of equations in order to test the wage spillovers. The model will be estimated is found by imposing (6.27) into (6.23). ${ }^{43}$

(6.29) $\dot{W}_{t t}=\varepsilon+\pi \dot{i}_{t t}+\sum_{a=1}^{k} \phi_{a} \dot{i}_{a t}+\rho i_{i t-1}+\lambda \dot{P}_{t}+\sigma\left(l_{t}^{-1}+\mu_{t} \dot{W}_{l t, t-1}\right.$

$\dot{W}_{I .} \Rightarrow$ the percentage change in the hourly wage rate of the leading sectors.

The addition of $\dot{W}_{L}$ to model given in equation (6.23) is the wages in the leading sectors. This can be done in two ways; either weighting these wages in leading sectors by employment rates and adding them as one variable, or adding them as separate variables. Although the second way gives more certain results, it may cause a degrees of freedom problem. Therefore, using employment-weighted wages in the leading sector(s) is a more appropriate way to introduce this variable. However, if wages in one or two sectors are identified as leading wages, they may be used separately.

\footnotetext{
42 Lag and lead lengths are chosen to be two by assuming that the contracts agreed upon can at most cover a two-year period.

$4:$ In calculating alternative wage, leading sectors are also included.
} 
After estimating equation (6.29), whether the real wage increases in the leading sector(s) produce wage increases in the nonleading sectors will be tested. The coefficient on variable $\dot{W}_{L}$ which can be called as the leadership coefficient should be positive if the wage leadership hypothesis holds. If the nonleading sectors precisely follow the leading sector(s), it should be equal to unity. If they follow weakly, the wage leadership coefficient will be positive but less than one.

The next step is to identify the determinants of wage leading-following behavior. For this purpose, two variables will be used, namely sectoral unionization rate $(I / R)$ and sectoral concentration ratio in terms of the first four largest firms' sales $((R t)$.

One basis for the wage leadership hypothesis is the idea that wage spillovers from one sector to another will basically take place through labor market institutions rather than market forces. If this is the case, it is expected that wage leadership and wage following behavior should be most evident in highly unionized sectors. This suggests that each of the leadership coefficients should be a function of the extent of unionization in that sector. That is,

(6.30) $\mu_{i}=\alpha_{0, i}-\alpha_{l, i} l / R_{i l}$

$U R \Rightarrow$ unionization rate in inchustry $i$.

In order to test this point of view of the wage leadership hypothesis the model in equation (6.29) is reestimated with equation (6.30) imposed. The estimating equation for this case will be

$$
\begin{aligned}
\dot{W}_{n}= & \varepsilon+\pi \dot{V}_{n}+\sum_{a=1}^{k} \phi_{a} \dot{H}_{a t}+\rho \dot{w}_{i t-1}+\lambda \dot{P}_{t}+\sigma l_{t}^{-1}+\mu_{t} \dot{W}_{t, t, t-1}+\alpha_{0, t} \dot{W}_{L, t,-1} \\
& +\alpha_{1, t}\left(I R_{t, l} \dot{W}_{i, t, t-1}\right.
\end{aligned}
$$

Then the hypothesis to be tested will be

(6.32) $H_{0}: \alpha_{l, i} \quad 0$

$H_{l}: \alpha_{l, i} \neq 0$

Furthermore, the transmission of wage changes from leading sectors to following sectors may be a result of product market structure. The wage changes first appear in the concentrated sectors and may be transferred from these sectors to the following sectors via labor market institutions. This means that leadership coefficient is a function of sectoral concentration ratios in the following way. 
('Rt $\Rightarrow$ four-firm concentration ratio in industry $i$.

Again this hypothesis can be tested by imposing equation (6.33) into equation (6.29) and reestimating it.

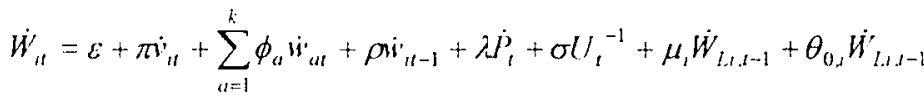

$$
\begin{aligned}
& +\theta_{1, i}\left(R 4_{i, I} \dot{W}_{i, i-1}\right.
\end{aligned}
$$

Then the hypothesis to be tested will be

(6.35) $H_{0}: 0_{1.1} \quad 0$

$$
H_{1}: \theta_{1,1} \neq 0
$$

The wage leadership hypothesis implies a causal ordering from the leading sectors to the following sectors. In other words, increases in wages in the leading sectors induce wage increases in the nonleading sectors, yet wage increases in the nonleading sectors do not cause wage increases in the leading sectors. This unidirectional causality is an important component of the wage leadership hypothesis. If there were bi-directional causality, this would indicate that wages in different sectors are simply intercorrelated with no explicit pattern of leading and following This may also imply that the positive results for the leadership coefficients reflect little more than the role of these sectors as part of the alternative wage set as defined in the neoclassical theory. The unidirectional causality denoted by the wage leadership hypothesis can be tested with a model designed by Granger (1969). Thus, the following equation is estimated

$$
\text { (6.36) } \dot{W}_{L, i, t} \cdot \gamma_{0, i} \cdot \gamma_{l, i} T \cdot \gamma_{2, i} \dot{W}_{l, i, t-1} \cdot \gamma_{3, i} \dot{W}_{\Lambda_{i, t-1}} \cdot \eta_{t}
$$

where $T$ is a linear time trend which is included in the regression to make the series stationary and $\eta_{f}$ is a disturbance term satisfying Gauss-Markov assumptions. In order to test the causality it should be tested that the $13, i$ coefficients are significantly different from zero. That is,

$$
\text { (6.37) } \begin{array}{rl}
H_{0}: \gamma_{3, i} & 0 \\
H_{l}: \gamma_{3.1} \neq 0
\end{array}
$$

If they are not significantly different from zero, then it is proved that the wage increases in the nonleading sector do not cause the wage increases in the leading sector. 


\subsection{Concluding Remarks}

In conclusion. this chapter provides the tools of analysis for the next chapter concerning the empirical application. First, we present the general properties of the bargaining models in detail. Then, by using the basic points of the previous section, a bargaining model is proposed. Finally, the wage leadership model as an extension of the bargaining models that includes the impact of spillover forces in the context of wage determination is formulated. In order to estimate the last model. we have to define how to determine wage-leading sector(s). This study proposes somewhat a cumbersome but a very reliable method for the determination of leading sector(s) since for each sector a separate equation is estimated and finally unidirectional causality is also tested for the proof of the first step. Moreover, our aim is not only to verify relevancy of the wage leadership model but also to search for the possible instiutional factors behind this behavior. For this end, sectoral unionization rate and sectoral concentration ratio are offered as possible sources. Tests for the effects of these variables will complcte the analysis. It is natural to think about some other relevant variables to our models but our models reflect the basic premises of looking at labor markets. 


\section{APPENDIX 6: A NOTE ON MODIFIED SIMS METHOD}

Granger (1969) has proposed a definition of causality in economic systems,

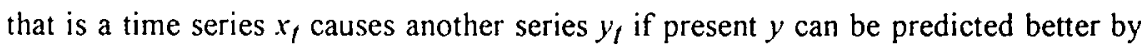
using past values of $x$ than by not doing so, other relevant information including the past of $y$ being used in either case. When the domain of relevant information is restricted to past values of $x$ and $y, x$ and $y$ are jointly covariance stationary time series with autoregressive representation, the set of predictors is constrained to be linear in past $x$ and $y$, and one's criterion for comparison of predictors is mean square error, therefore the question of whether $x_{1}$ causes $y_{l}$ is equivalent to question of whether there exists an autoregressive representation,

(A.1) $\left(\begin{array}{l}x_{t} \\ y_{t}\end{array}\right)=\left[\begin{array}{ll}d(L) & e(L) \\ a(L) & b(L)\end{array}\right]\left(\begin{array}{l}x_{t} \\ y_{t}\end{array}\right)+\left(\begin{array}{l}\varepsilon_{t} \\ \delta_{t}\end{array}\right)$

where $e(L)=0$.

A test of proposition that $x$ does not cause $y$ contains estimating A.1 by ordinary least squares (OLS) and testing the hypothesis of $e(L)=0$ since A.1 is a set of population regression equations with serially uncorrelated disturbances. This test is known as Granger causality test. If one does not have special knowledge which restricts $d(L)$ and $\mathrm{e}(\mathrm{L})$ to be known functions of parameters whose number is reasonably small relative to sample size, nevertheless, this cannot be done. In actual applications such as Sargent (1976) and Geweke (1978), some arbitrary restrictions on the form of $d(L)$ and $e(L)$ must be made before estimation and testing can proceed; for instance, $d(L)$ and $\mathrm{e}(\mathrm{L})$ might be assumed to be polynomials of finite order, or ratios of polynomials of finite order. If the restrictions hold, then the asymptotic properties of traditional tests of $\mathrm{e}(\mathrm{L})$ are well known. If the restrictions do not hold, such test will reject the null hypothesis $e(L)=0$ asymptotically even if the null hypothesis is true

Sims (1972:543-46) regarded the effects of the condition $e(l)=$.0 for the projection of $y_{1}$ on current and past $x_{l}$,

(A.2) $y_{t} \quad f_{l}(L) x_{t}-u_{t}=\sum_{s=0}^{\prime} f_{l s} x_{t-S}-u_{t}$

where $\operatorname{cov}\left(u_{1}, x_{1-.}\right)=0$ and $s \geq 0$.

Moreover, Sims (1972:544-45) also considered the projection of $y_{l}$ on future, current and past $x_{i}$, 
(A.3) $y_{1} f_{2}(I.) x_{1} \cdot y_{1} \quad \sum_{s}, f_{2 s} x_{1-5}-y_{1}$

where cov $\left(1, x_{1-. .5}\right) \cdots, \forall s$.

Sims (1972:550-51) indicated that $e(l) \quad O.\left(x_{1}\right.$ does not cause $\left.y_{l}\right)$ if and only if the second projection includes only current and past $x_{l}$, so that $f_{l}(l)=f_{2}(L)$. If such a test is to be realized, $f_{1}(L)$ and $f_{2}(l$.$) must be restricted for the same reasons that d(L)$ and $e(I)$ were restricted in conducting a Granger causality test. Furthermore, since $\|_{t}$ and $y$ are serially correlated, a feasible generalized least squares (FGLS) estimator that restricts autocovariance functions of $u_{l}$ and $v_{l}$ to be known functions of a reasonable number of parameters must be used in applying the test proposed by Sims (1972). Once again, the asymptotic bias against the null hypothesis that would result from maintaining restrictions on $f_{l}(L)$ and $f_{2}(L)$ may be removed by allowing the number of estimated parameters to increase with the sample size. Appropriate rates of parameter expansion are unknown as in the previous case.

However, there is an extension of the test proposed by Sims (1972) in which there is no need to use a FGLS estimator to contend with serial correlation in $\|_{l}$. This test is formulated by Geweke. Meese. and Dent (1983). First, the system of equations in $\mathbf{A . 1}$ is multiplied by the matrix

$$
\left[\begin{array}{ccc}
1 & 0 \\
-c / \sigma_{\varepsilon}^{2} & 1
\end{array}\right]
$$

where $c=\operatorname{cov}\left(\varepsilon_{l}, \delta_{l}\right)$. That is,

$$
\text { (A.5) } \begin{aligned}
{\left[\begin{array}{cc}
1 & 0 \\
-c / \sigma_{\varepsilon}^{2} & 1
\end{array}\right]\left(\begin{array}{l}
x_{t} \\
y_{t}
\end{array}\right) } & =\left[\begin{array}{cc}
1 & 0 \\
-c / \sigma_{\varepsilon}^{2} & 1
\end{array}\right]\left[\begin{array}{ll}
d(L) & e(L) \\
a(L) & b(L)
\end{array}\right]\left(\begin{array}{l}
x_{t} \\
y_{t}
\end{array}\right) \\
& {\left[\begin{array}{cc}
1 & 0 \\
-c / \sigma_{\varepsilon}^{2} & 1
\end{array}\right]\left(\begin{array}{l}
\varepsilon_{t} \\
\delta_{t}
\end{array}\right) }
\end{aligned}
$$

This gives a new system where the first equation is the first equation in $\mathbf{A . 1}$ and the second equation is written as.

(A.6) $y_{1} g^{-}\left(l, y_{l} \cdot f^{*},\left(l, x_{1} \cdot \omega_{l}\right.\right.$

$$
\sum_{, 1}^{\prime} g_{s^{\prime} /-s} \cdot \sum_{, n}^{\prime} f_{/ S}^{*} x_{t-s}-\varpi_{1}
$$


where $g *(I)$ and $f^{*}{ }_{I}(L)$ are functions of the parameters in equation A.1 Since $w_{l}=\delta_{t}$ - $\left(c \sigma^{2} \varepsilon\right) \varepsilon_{l}$, it is uncorrelated with $\varepsilon_{l}$, and consequently $\varpi_{l}$ is uncorrelated with current $x_{l}$, past $x_{l}$, and $y_{l}$. Hence, the right-hand side variables of equation A.6 are exogenous and $\varpi_{t}$ is serially uncorrelated. Geweke, et.al. (1983:164-65) assumed that $v_{f}$ in equation A.3 has an autoregressive formulation such that

(A.7) $h(I.) v_{l}=\xi$

and

(A.8) $h(L)=I-h^{*}(L)$

(A.9) $f_{2}^{*}(l)=h(I) f_{2}(L)$.

If both sides of A.3 is multiplied by $h(L)$, we get

(A.10a) $h(L) y_{t}=h(L) f_{2}(L) x_{t} * h(L) v_{t}$

By using equation A.9, we obtain

(A.10b) $h(L) y_{t}: f^{*}{ }_{2}(L) x_{t}: h(I.) y_{t}$

and from equations $\mathbf{A . 7}$ and $\mathbf{A . 8}$ it is derived that

(A.10c) $\left[1-h^{+}(L)\right] v_{t}=\xi_{1}$

that is.

(A.10d) $y_{f}-h(L) y_{f}=\xi_{t}$

Substituting equation A.8 into equation A.10b gives

(A.10e) $\left[1-h^{*}(I) / y_{l} \cdots f^{*} 2^{(L)} x_{l} \cdots\left[I-h^{-}(L)\right] v_{t}\right.$

By rearranging and substituting $\mathbf{A . 1 0} \mathrm{c}$ into $\mathbf{A} .10 \mathrm{e}$, we obtain

(A.10ก) $y_{t}-h^{*}(L) y_{t}=f^{*}{ }_{2}(L) x_{t}: \xi_{t}$

with a final rearrangement it is found that

(A.10) $y_{t} \cdot f^{*} 2(L) x_{l} \cdot h(L) y_{t} \cdot \xi_{t}$

or A.10 can also be rewritten as

(A.11) $y_{t}-\sum_{r=1}^{r} h^{*} y_{t-S}-\sum_{t=-, r}^{s} f_{2 s^{x} t-s}^{*} \cdot \xi_{t}$

Now, the disturbance $\xi_{t}$ is serially uncorrelated. It is uncorrelated with all $x_{t-s}$ since it is a linear combination of disturbances in the projection in equation $\mathbf{A . 3}$ and it is also uncorrelated with past values $x_{i}$ since these are linear combinations of all $x_{1-s}$ and past 5 . Furthermore, $f_{2 s}^{*}=0$ for all $s: 0$ if and only if $f_{2 s}=0$ for all $s \cdots 0$ because 
$h(L)$ is invertable. Therefore, the test for the hypothesis that $x_{t}$ does not cause $y_{f}$ proposed by Sims (1972) may be carried by using a test of $f^{*} 2 s ; 0$ for all $s+0$ on the estimates of some finite parametrization of equations A.6, A.10, and A.11 in the traditional way. The number of parameters in $g^{+}(L), h^{+}(L), f^{*}{ }_{l}(L)$, and $f^{*}{ }_{2}(L)$ that are estimated must again increase with the sample size.

A test of $f^{*} 2 s \quad 0$ for all $s \quad 0$ can be based on the sums of squared residuals from ordinary least squares of the regression equations

(A.12) $y_{t}: F^{*}{ }_{l}(L) x_{l} \cdot\left(; *(l) y_{l} \cdot H_{l}\right.$

$$
=\sum_{t=1}^{r}\left(; \quad y_{t-S} \cdot \sum_{, 0}^{4} F_{l . S}^{*} x_{t-S} \cdots H_{t}\right.
$$

and

$$
\begin{aligned}
& \text { (A.13) } y_{l}=F^{*} 2(I) x_{1} \cdots H(L) y_{t} \cdot W^{-} \\
& \sum_{s=1}^{\prime} H^{*} y_{t-s}^{\prime} \cdot \sum^{q}, F^{*}{ }_{2 s^{x}}^{x_{1-s}} W_{1}
\end{aligned}
$$

If $\hat{\sigma}^{2} H$ is the maximum likelihood estimate of $\operatorname{var}\left(H_{l}\right)$ in $\mathbf{A . 1 2}$ and $\hat{\sigma}^{2} W$ is the maximum likelihood estimate of $v a r\left(W_{\nu}\right)$ in $\mathbf{A . 1 3}$, then the corresponding Wald $\left(\mathrm{T}^{\mathrm{W}}\right)$, likelihood ratio $\left(\mathrm{T}^{\mathrm{LR}}\right)$, and Lagrange multiplier $\left(\mathrm{T}^{\mathrm{LM}}\right)$ tests are given by

(A.14) $T^{w}{ }_{n} \cdots n\left(\hat{\sigma}^{2} H-\hat{\sigma}^{2} W\right) \hat{\sigma}^{2} W-\chi^{2}(p)$

(A.15) $T L R_{n} \cdots n \ln \left(\hat{\sigma}^{2} H \hat{\sigma}^{2} W\right)-\chi^{2}(p)$,

(A.16) $T M_{n}=n\left(\hat{\sigma}^{2} H-\hat{\sigma}^{2} W\right) \hat{\sigma}^{2} H \sim \chi^{2}(p)$.

According to Monte Carlo experiments carried out by Geweke et.al (1983:178-85), Wald test should be preferred over other proposed test statistics since the approximate slopes of this test is at least as great as those of other tests, the sampling distribution of Wald test under the null hypothesis is very satisfactory, and under the alternative rejection frequencies correspond very closely to those indicated by the asymptotic theory. Therefore, in this study the test statistics given in equation A.14 will be used to test the wage leadership hypothesis. 


\section{PART III: WAGE DETERMINATION PROCESSES IN THE DUTCH AND TURKISH MANUFACTURING INDUSTRIES}

Part III consists of chapters 7-9. In chapters 7 and 8, wage determination processes in the Dutch and Turkish manufacturing industries will be examined respectively. For each country, first, a bargaining model then, as an extension of this model, the wage leadership model will be estimated. The method of estimation in both cases is Seemingly Unrelated Regression (SUR) method. In the context of the wage leadership model, a method for choosing the wage leading sectors will also be outlined. Chapter 9 will be devoted to the policy implications of findings in chapters 7 and 8 in the context of corporatism and centralization debate. 


\section{WAGE DETERMINATION PROCESS IN DUTCH MANUFACTURING INDUSTRY}

\subsection{Introduction}

In this chapter of the study, the previously proposed models of wage inflation will be analyzed econometrically after they are adjusted for the availability of the data. First, the bargaining model of wage inflation is studied. Second, the wage leading sectors in Dutch Manufacturing Industry are determined. Third, we estimate the wage leadership model. Finally, the extensions of the wage leadership model in the context of the determinants of wage leading and following behavior are studied. All the models are estimated by the Seemingly Unrelated Regression (SUR) method. This study is concentrated only on the manufacturing industry because of the data limitations on other sectors and reliability of the manufacturing data. Nevertheless, we have still some problems with the existing data on manufacturing industry. The data sources and possible shortcomings of the data are discussed in the appendix.

\subsection{A Bargaining Model of Wage Inflation}

In order to assess the relevancy of the bargaining model of wage inflation for 26 sectors of the Dutch Manufacturing Industry, the following equation is estimated by SUR. The estimation results can be seen in Table 7.1.44

$$
\begin{aligned}
\dot{W}_{i t} & =\beta_{0}+\beta_{1, i} \dot{v} a_{i t}+\beta_{2, i} \dot{w}_{a, t}+\beta_{3, i} \dot{w}_{i, t-1}+\beta_{4, i} \dot{m} w_{t}+\beta_{5, i} \dot{u} b_{t}+\beta_{6, i} \dot{P}_{l}^{e} \\
& +\beta_{7, i}(V-U)_{t-1}+\varepsilon_{t}
\end{aligned}
$$

where $i=1, \ldots, 26, t=1971, \ldots, 1993, \varepsilon_{t} \sim N\left(0, \sigma^{2}\right)$, all relevant variables are in the rate of growth and

$W_{i} \Rightarrow$ nominal hourly wages in industry $i$.

$v a_{i} \Rightarrow$ real value added per hour in industry $i$,

$w_{a} \Rightarrow$ alternative wages set,

$w_{i} \Rightarrow$ real hourly wages in industry $i$,

$m w \Rightarrow$ real minimum wage paid in the economy,

44 The bargaining model is also estimated by using the inverse of one-period lagged unemployment rate. The results of this model are presented in the appendix but our original model with one-period lagged vacancy-unemployment rate performs better. Therefore, this model will be discussed throughout the rest of study. 
$u b \Rightarrow$ real unemployment benefit paid to a typical worker in the economy.

$P^{e} \Rightarrow$ expected prices,

$V \Rightarrow$ vacancy rate,

$U \Rightarrow$ unemployment rate.

The expected signs of the variables in the model are as follows: ${ }^{45}$

- Value Added (va): This variable is used as a proxy for the change in labor productivity. The value added per hour is calculated and deflated by the sectoral price indices. The expected sign of this variable is positive, that is to say, as productivity increases wages tend to increase.

- Alternative Wage Set $\left(w_{a}\right)$ : Alternative wage set is one of the three components of the opportunity cost of labor. A positive relationship is expected between percentage change in wages of alternative employment opportunities and percentage change in nominal wage. The relationship is twofold. First, in order not to lose the workers, especially the skilled component of their labor force, firms should follow the increase in nominal wages paid elsewhere in the economy. Second, in terms of efficiency wage theory, because of equity and faimess concerns firms should increase the nominal wages during the time when the general wage level is increasing. By doing so firms attempt to prevent the decline in productivity of their workers.

- Minimum Wage (mw): It is the second component of the opportunity cost of labor. The explanations made for the alternative wage set are also valid for the percentage change in real minimum wages determined in the economy.

- Unemployment Benefits (ub): The percentage change in unemployment benefits is the last variable to measure the effects of opportunity cost of labor. Again, the expected sign is positive.

- Past Wage Changes $\left(\mathbf{w}_{t-1}\right)$ : The use of this variable is in conformity with the real wage adjustment lag hypothesis. The expected sign of percentage change in oneperiod lagged real wages is positive.

- Expected Rate of Growth in the Price Level (Pe): The expected rate of growth in consumer price index (CPI) is used. Price changes are assumed to influence workers in all sectors equally. The duration of employment contracts affects the 
time path of price influence on wages. Most of the studies in the literature found that especially first-year wage adjustments in currently negotiated agreements are significantly influenced by price changes. ${ }^{46}$ Moreover, for most of the estimation period, the union agreements generally include terms that second-year and thirdyear wage adjustments are indexed to cost of living allowances (COLA) or CPI. However, neither a rational expectations nor an adaptive expectations price formation is used in this study, rather a mixture in which past, present and future price changes are weighted equally is employed. The expected sign of this variable is positive.

- Excess Demand for Labor (V-U): This variable is used as a proxy to measure the excess demand for labor. Its expected sign is positive since the nominal wages tend to increase to attract the existing labor force when the gap between vacancy and unemployment rates widens. It is lagged one period because the effects of change in excess demand are reflected in the next periods' wages.

The first interesting result of this table is the insignificant estimates for the value added variable which is used as a proxy for the labor productivity. Only in 6 sectors, these estimates are found to be significant. Moreover, in 5 of these sectors its sign is positive as expected. However, it should be noted that the constant term is large and significant for some sectors and it may capture the effects of productivity on wage changes in some extent.

Alternative wage set that is evaluated as one of the three components of opportunity cost of labor is highly significant for the Dutch Manufacturing Industry and the positive sign of estimates are in close conformity with our expectations. In 5 sectors, the coefficients are found as insignificant.

The other components of the opportunity cost of labor are minimum wages and unemployment benefits for the whole economy. In 5 sectors in which nominal wage changes are not explained by the changes in the alternative wage set, the nominal wage changes are explained by either the changes in minimum wages or changes in unemployment benefits. However, some of the signs are negative and this contradicts with our expectations.

\footnotetext{
${ }^{45}$ The introduction of intercept term will consider the productivity effects and the effects of wage drift.

${ }^{46}$ For the examples of such studies, see Driehuis (1975), Flanagan (1976), Bemmels and Zaidi (1990), and Graafland and Verbruggen (1993).
} 


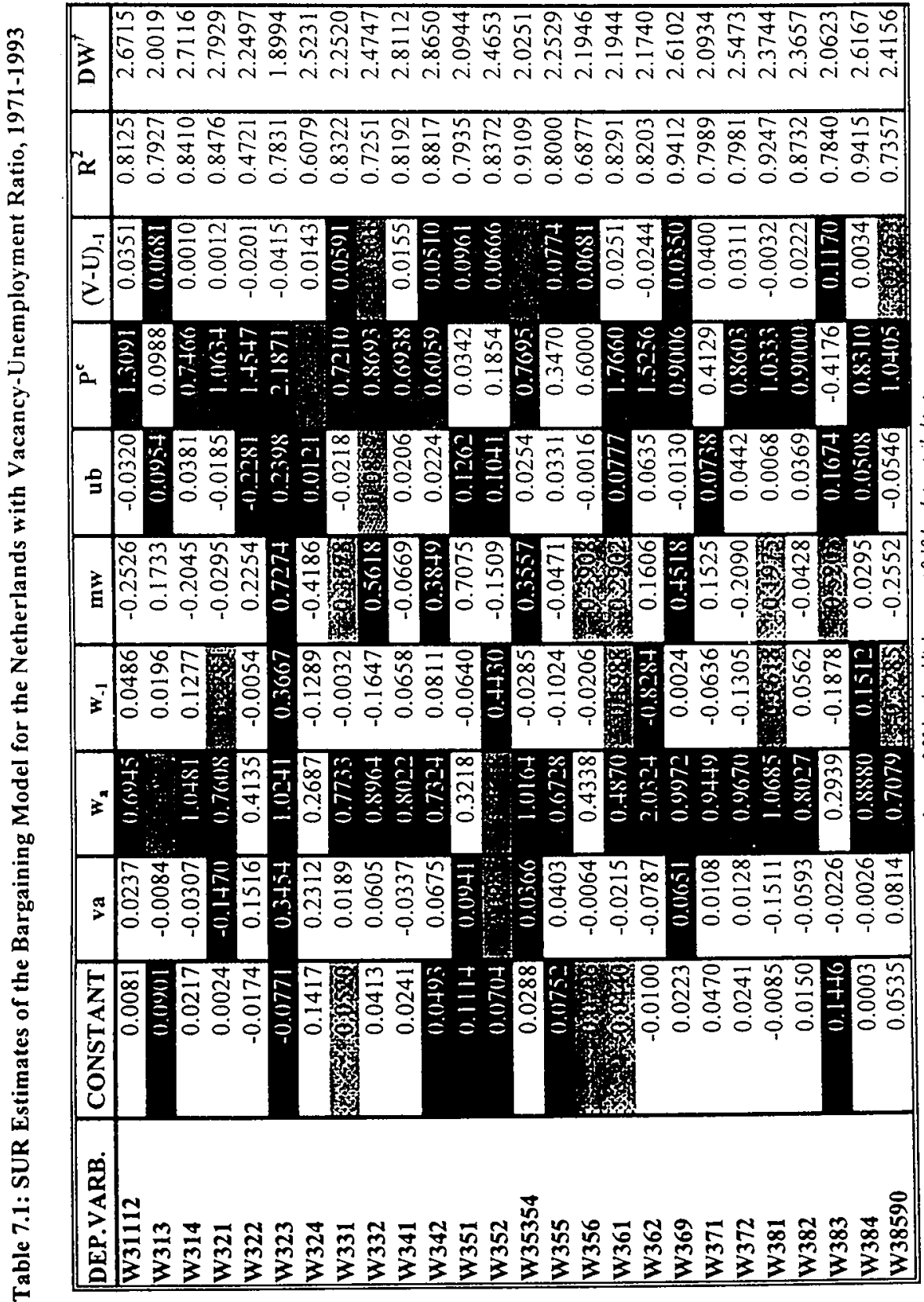


The estimates for past real wage changes do not generally determine the rate of nominal wage changes. For 8 sectors, the coefficients are significant and two of them are negative. This is in favor of the predictions of the real wage adjustment lag hypothesis.

Price expectations are highly significant in the determination of wages in the Dutch Manufacturing Industry. 19 significant coefficients show that change in expected prices plays an important role for the wage demands of workers. Its positive sign implies that increases in CPI is followed by the increases in nominal wages in some extent.

Finally, the vacancy unemployment rate which is used to assess the degree of labor market tightness is an important variable in the Dutch wage determination process. In 12 sectors, coefficients of this variable are significant. Furthermore, its positive sign as expected shows that increases in excess demand for labor cause firms to increase nominal wage offers to attract labor force or vice versa.

In sum, the simple bargaining model is not as adequate as expected to explain the growth of money wages for the Dutch Manufacturing Industry. Surprisingly value added and real wage variables are not significant for most of the sectors. Only measures of labor market tightness and opportunity cost of labor give significant results. Therefore, the bargaining model is far away to explain the growth rate of nominal wages with the above formulation. The next step is to consider the impact of institutional factors on the wage determination process.

\subsection{The Wage Leadership Model}

The first step to formulate the wage leadership model is to find the wage leading and following sectors. In order to determine these sectors modified Sims method (Geweke, et.al, 1983:163) is used and equations given by 6.28 are estimated for each sector. Respective coefficients $-\beta_{6}$ and $\beta_{7}$ - are tested by applying the Wald test statistics since it has desirable properties as compared to other test statistics as discussed in the appendix to chapter 6. 
(7.2) $\dot{W}_{N_{i, t}}=\beta_{0}+\beta_{l, i} \dot{W}_{N_{i, t-1}}+\beta_{2, i} \dot{W}_{N_{i, t-2}}+\beta_{3, i} \dot{W}_{L_{i, t}}+\beta_{4, i} \dot{W}_{L_{i, t-1}}+\beta_{5, i} \dot{W}_{L_{i, t-2}}$

$$
+\beta_{6, i} \dot{W}_{L i, I+1}+\beta_{7, i} \dot{W}_{L_{i, t}+2}+u_{t}
$$

where $i=1, \ldots, 26, t=1971, \ldots .1993$, and $u_{t} \sim \mathrm{N}\left(0, \sigma^{2}\right)$,

$W_{L} \Rightarrow$ percentage change in the hourly wage rate of the leading sectors,

$W_{N} \Rightarrow$ percentage change in the hourly wage rate of the following sectors.

In equation (7.2), the hypothesis $\beta_{6}+\beta_{7}>0$ is tested for both the leading and nonleading sectors. The detailed results of Wald test statistics are presented in Tables $7.2 \mathrm{a}, 7.2 \mathrm{~b}$, and 7.2 .

Sectors 342 (Printing, Publishing and Allied Industries) and sector 351 (Manufacture of Industrial Chemicals) are found to be wage leading sectors for the Dutch Manufacturing Industry. Sector 351 has been followed by 21 sectors and it has only one leading sector at $5 \%$ significance level. On the other hand, sector 342 has been followed by 17 sectors and has 2 leaders again at 5\% significance level. At first sight, sector 355 (Manufacture of Rubber Products) can be treated as one of the wage leaders with 18 following sectors. However, the number of leading industries (4) is greater than that of the sectors 342 and 351 . There may also be some doubt related with sector 371 (Iron and Steel Basic Industries) but the number of follower (13) for this industry is less than that of the sectors 342 and 351 . Another point that shoul be kept in mind is that sector 322 (Manufacture of Wearing Apparel) is exactly neither a leader nor a follower. The same consclusion is also valid for sector 323 (Manufacture of Leather) in some extent.

Therefore, after a careful analysis of Table 7.2 at $5 \%$ and $10 \%$ significance levels, it is possible to state that sectors 342 and 351 are the wage leading sectors for the Dutch Manufacturing Industry in the period 1973-1991. Our results are consistent with the findings of Graafland and Verbruggen (1993).

In their analysis on Dutch economy, Graafland and Verbruggen (1993) also found some evidence for the wage leading behavior of the paper and printing industry and the chemical industry. However, as opposed to findings of Graafland and Verbruggen (1993), we do not find the food processing and the wood and building materials industries as the wage leaders. 


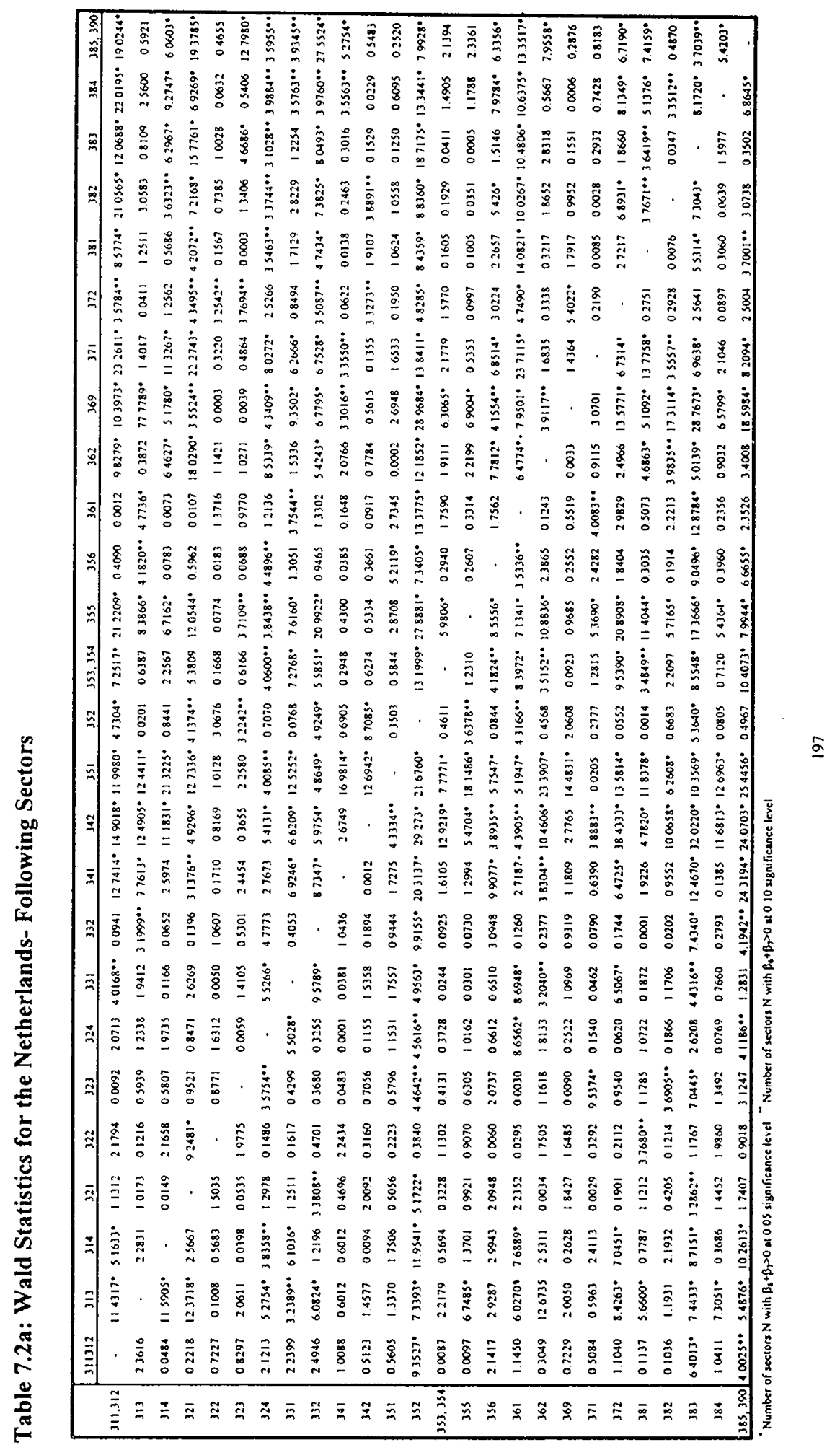




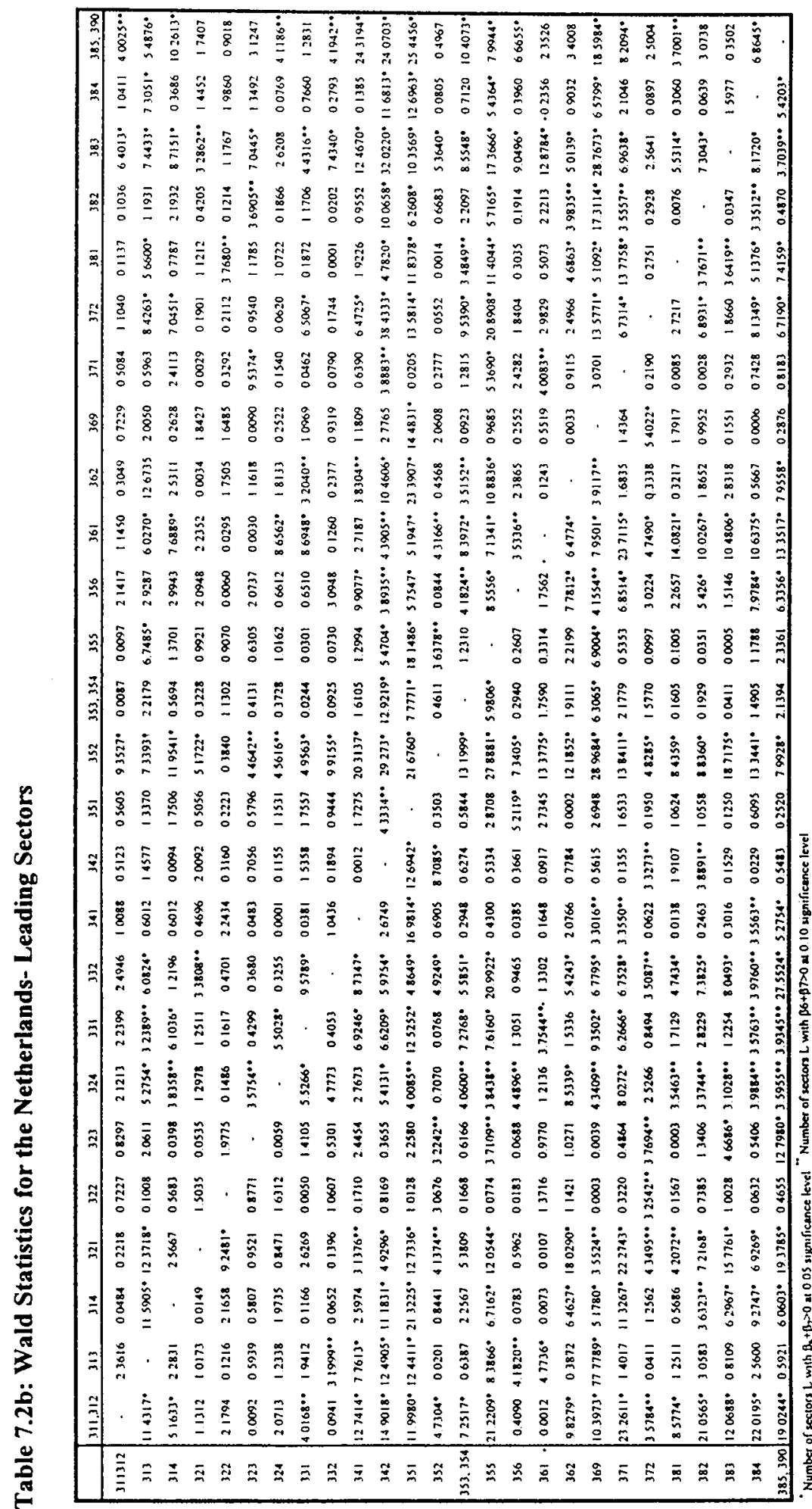




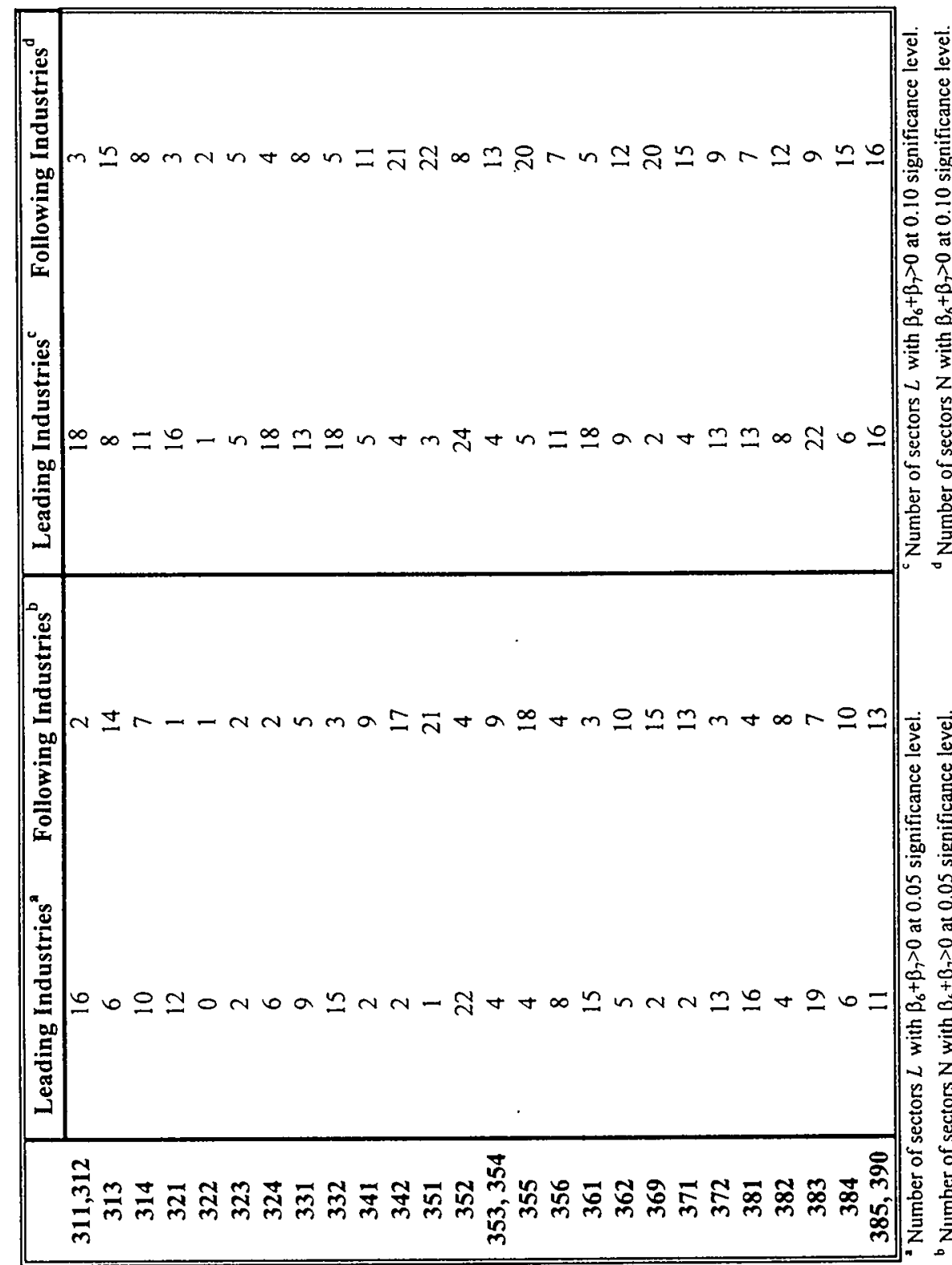


Another test is related with the unidirectional causality denoted by the wage leadership hypothesis since the wage leadership hypothesis claims that increases in wages in the leading sectors cause wages in the nonleading sectors to increase but increases in wages in the nonleading sectors do not cause wages in the leading sectors to increase. In order to test this unidirectional causality, Granger test given in equation 6.36 is carried out.

(7.3) $\dot{W}_{L, i, t}=\gamma_{0, i}+\gamma_{l, i} T+\gamma_{2, i} \dot{W}_{L_{i, t-1}}+\gamma_{3, i} \dot{W}_{N_{i, t-1}}+\eta_{t}$

where $T$ is a linear time trend which is included in the regression to make the series stationary. ${ }^{47}$

The hypothesis to be tested is,

(7.4) $H_{0}: \gamma_{3, i}=0$

$$
H_{l}: \gamma_{3, i} \neq 0
$$

If these coefficients are insignificant, then it is verified that the wage increases in the nonleading sectors do not cause wage increases in the leading sectors.

The results of Granger causality tests are presented in Table 7.3. Apart from the leading sectors 342 (Printing, Publishing and Allied Industries) and 351 (Manufacture of Industrial Chemicals), two significant coefficients are observed in Table 7.3. These belong to sectors 313 (Beverage industries) and 322 (Manufacture of wearing apparel). If Table 7.3 is analyzed with Table 7.2 simultaneously, it is observed that sector 322 has no leading industry and only one following industry. Therefore, the wage determination process in this sector is independent of the wage leading-following behavior. As a result of Granger causality tests, only sector 313 violates the predictions of the wage leadership hypothesis.

After the determination of the wage leading industries, we can continue with the estimation of the wage leadership model. Again the estimation method is SUR. There are two additions to the bargaining model. One of them is the rate of growth of wages in the wage leading industries. This variable is calculated by using the share of employment as weights and it is lagged by one period. Hence, it is an employmentweighted average of wages in sector 342 and 351 . The second addition to the model is the variable accounting for the effects of international trade on the growth of money wages.

${ }^{47}$ Adding time trend seems to be necessary as a result of the unit root tests. 
Table 7.3: Granger Causality Results for the Netherlands

\begin{tabular}{|l|c|}
\hline \multicolumn{1}{|c|}{ DEP.VARB. } & $W_{N \cdot 1}$ \\
\hline WL31112 & -0.0927 \\
WL313 & 0.2663 \\
WL314 & 0.0629 \\
WL321 & -0.1651 \\
WL322 & -0.1436 \\
WL323 & -0.0013 \\
WL324 & 0.0382 \\
WL331 & 0.0056 \\
WL332 & -0.0737 \\
WL341 & 0.2209 \\
WL342 & 0.2747 \\
WL351 & 0.2924 \\
WL352 & -0.0604 \\
WL35354 & 0.1845 \\
WL355 & 0.0441 \\
WL356 & 0.1282 \\
WL361 & -0.0299 \\
WL362 & -0.0676 \\
WL369 & 0.1433 \\
WL371 & 0.1319 \\
WL372 & 0.1056 \\
WL381 & -0.0356 \\
WL382 & 0.0996 \\
WL383 & 0.0969 \\
WL384 & 0.0588 \\
WL38590 & 0.2319 \\
\hline
\end{tabular}

- Dark shaded areas imply that the respective coefficients are significant at 0.05 level.

This addition may be blamed as being intuitive, even though this critique is relevant in some extent, we want to strip the effects of international trade from that of spillover effects. Moreover, there are some empirical studies explaining the importance of such a variable. This variable is the sectoral ratio of international competitiveness, $R I C$. $R I C$ is measured by the ratio of net exports (exports minus imports) to total trade (exports plus imports). If this ratio is close to unity, this will mean increase in competitiveness. Some studies, like Edgren, et.al. (1973), use this variable for the determination of wage leading sector(s). Another study, Erdil (1996a), shows that ratio of international competitiveness explain the differences in wages for Turkish case. As Visser and Hemerijck (1997:17) stated that the Central Accord concluded between central union and employers federations in 1982 included the idea of sustained policy of wage moderation to lower the real exchange rate and improve price competitiveness of Dutch firms and products. Although there is not very strong empirical support for the inclusion of this variable, to test the effects of relative 
competitiveness in international markets on wage changes, it is added somewhat intuitively. Therefore, this variable is used to capture the effects of international trade on the percentage change in wages. ${ }^{48}$

$$
\begin{aligned}
\dot{W}_{i t} & =\beta_{0}+\beta_{1, i} \dot{v} a_{i t}+\beta_{2, i} \dot{w}_{a, t}+\beta_{3, i} \dot{w}_{i, t-1}+\beta_{4, i} \dot{m} w_{t}+\beta_{5, i} \dot{u} b_{t}+\beta_{6, i} \dot{P}_{t}^{e} \\
& +\beta_{7, i}(V-U)_{t-1}+\beta_{8, i} \dot{W}_{l, t-1}+\beta_{9, i} R I C_{i, t}+\varepsilon_{t}
\end{aligned}
$$

$\dot{W}_{L} \Rightarrow$ percentage change in the hourly wage rate of the leading sectors,

$R I C_{i} \Rightarrow$ ratio of international competitiveness for sector $i$.

The expected signs of new variables in the model are discussed as follows:

- Leadership Variable $\left(\mathbf{W}_{L}\right)$ : This variable is calculated as the percentage change in real hourly contract wages of wage leading sectors. As explained previously, it should be positive if the wage leadership hypothesis is valid.

- Ratio of International Competitiveness (RIC): The implementation of wage moderation policies is an important factor in adjusting the Dutch economy to changing external conditions and to adopt to much tougher international competition in foreign and domestic markets. The sign of the coefficient of this variable which takes into account the impact of international trade on the percentage change in nominal wages is ambiguous. Since competitiveness may require lower prices with lower labor costs, the expected sign may be negative. However, in order to be competitive, technologically efficient methods of production are needed and such a technology calls for a skilled labor force demanding higher wages. In this line of logic, a positive relation is expected.

The results for this equation are given in Table 7.4 below. ${ }^{49}$

It is evident from Table 7.4 that the results are improved by the introduction of new variables if compared to the results of the bargaining model.

First, the number of sectors for which productivity matters in the wage determination process increases from 6 sectors in Table 7.1 to 9 sectors in Table 7.4. The same conclusion is also true for the real wage variable.

\footnotetext{
48 The complete model includes two more variables, sectoral profitability and wage drift, but the time series data on these variables are not available for both the Netherlands and Turkey for the time period considered and for subsectors of the manufacturing industry. Therefore, the discussion of the complete model including these variables is presented in the appendix.

${ }^{49}$ See appendix for the estimates of model with inverse of unemployment.
} 


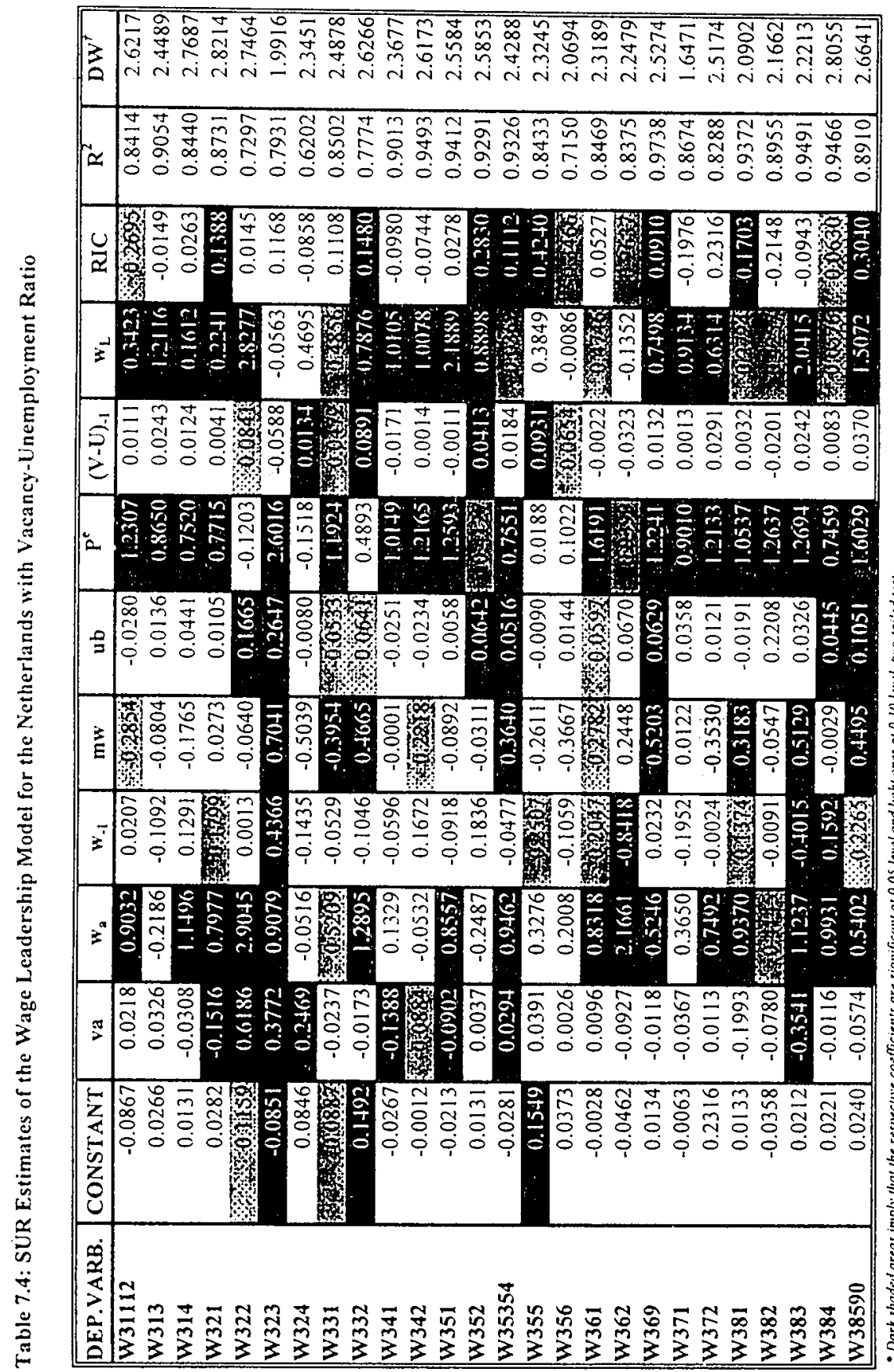


In addition to the opportunity cost of labor variables, we now have a wage leadership variable that workers also make wage comparisons by using the wage changes in the wage leading industries. We have, however, 6 sectors with wage changes that are not explained by the opportunity cost of labor variables. However, in 3 of these sectors, the wage leadership coefficients are significant. In 21 sectors, the wage leadership coefficients are found to be significant.

Moreover, for all of these sectors, the signs of these coefficients are positive; this validates the wage leadership model. ${ }^{50}$

Below, detailed tests for these coefficients will be carried out in order to test the nature of this leading-following behavior. In general, the wage leadership coefficients satisfactorily explain the changes in money wages and improve the performance of the bargaining model.

The international trade variable - Ratio of International Competitiveness- is found to be significant in 12 sectors. In 10 sectors, its positive sign may imply that in order to be competitive in the international markets firms use technologically efficient production techniques and this necessitates skilled labor force demanding higher wage changes. Unfortunately, it is not possible to test this proposition because of the unavailability of the data. In 2 sectors, it has negative sign. This means that competitiveness requires lower product prices with lower labor costs.

After estimating the wage leadership model, we continue our analysis with a closer look to the wage leadership coefficients. As explained previously, we make a behavioral assumption about the wage leadership coefficients. These coefficients should be positive if the nonleading sectors follow the leading sectors. Moreover, it should be equal to unity if they precisely follow the leading sectors. To decide the number of sectors with these properties, following two hypotheses will be tested by usual t-statistics:

(7.6) $H_{0}: \beta_{8, i}>0$

and

(7.7) $H_{l}: \beta_{8, i i}=1$

\footnotetext{
${ }^{50}$ For sectors 342 and 351 , the wage leadership coefficients are significant since it is assumed that each of these sectors follow a common wage-setting pattern. Moreover, the coefficients are different from zero because in constructing the wage leadership variable the employmentweighted averages are used.
} 
The results of these tests are given in Table 7.5. In the Dutch Manufacturing Industry, as can be seen from the first column of Table 7.5, 12 sectors weakly follow the wage leading industries. Morcover, 9 sectors precisely follow the wage leading industries with coefficients equal to unity. 5 sectors do not follow the wage leading industrics in either form.

Table 7 .5: Tests of Wage Leadership Hypothesis for the Netherlands with Vacancy-Unemployment Ratio, 1971-1993

\begin{tabular}{|c|c|c|}
\hline DEP.VARB. & $w_{L}>0$ & $w_{L}=1$ \\
\hline NW31112 & 1.9063 & 3.5543 \\
\hline NW313 & 3.9175 & 0.6841 \\
\hline NW314 & 1.8157 & 2.9942 \\
\hline NW321 & 17709 & 0.6709 \\
\hline NW322 & $3.5041^{\circ}$ & 4.7433 \\
\hline NW323 & 0.1116 & 0.1935 \\
\hline NW324 & 0.5988 & 0.6766 \\
\hline NW331 & jedozo & 1.1725 \\
\hline NW332 & 1.8495 & 3.7439 \\
\hline NW341 & 3.2654 & 0.0338 \\
\hline NW342 & 3.3112 & 0.0256 \\
\hline NW351 & 5.7038 & 3.0979 \\
\hline NW352 & 2.7830 & 0.3447 \\
\hline NW35354 & 413600 & 1.3272 \\
\hline NW355 & 0.9132 & 1.2596 \\
\hline NW356 & 0.0129 & 0.5097 \\
\hline NW361 & 944259 & 1.3089 \\
\hline NW362 & 0.1942 & 0.6311 \\
\hline NW369 & 3.9242 & 1.3095 \\
\hline NW371 & 2.1564 & 0.2044 \\
\hline NW372 & 2.3856 & 0.8089 \\
\hline NW381 & 13800 & 1.3181 \\
\hline NW382 & 1,43722 & 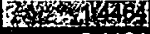 \\
\hline NW383 & 6.1006 & 3.1124 \\
\hline NW384 & $8 \times 461 ; 667$ & 4.8939 \\
\hline NW38590 & 3.8786 & 1.3053 \\
\hline
\end{tabular}

- Dark shaded areas imply that the respective coefficients are signiffcant at 0.05 level and light one's at 0.10 level.

As a conclusion, it can be stated that the wage leadership model sufficiently explains the rate of growth of money wages in the Dutch Manufacturing Industry. There is a substantial evidence that proves the existence of the wage leading and following behavior in the Dutch Manufacturing Industry.

\subsection{Sources of Wage Leadership}

After finding some evidence on the existence of wage leading and following behavior, we can look for the possible sources of this behavior. One of the sources through which wage spillover from one sector to another takes place is unions. The 
unionization rate may be a determinant of the wage leading-following behavior. In order to test this hypothesis, each of the leadership coefficients should be a function of the unionization rate as summarized by equations 6.30 and 6.31 . It is possible to ask that instead of unionization rate coverage rate by collective agreements should be used. One of the bases for the wage leadership hypothesis is the notion that wage spillovers from one sector to another will mainly come about through labor market institutions. If this is the case, it would be expected that wage leading and following behavior is most evident in the highly unionized sectors which is shown by the membership rates in each sector. This, in turn, implies that each of the leadership coefficients should be a function of the extent of unionization in that industry rather than coverage rate by collective agreements.

The estimated equation is as follows:

$$
\begin{aligned}
\dot{W}_{i t} & =\beta_{0}+\beta_{1, i} \dot{v} a_{i t}+\beta_{2, i} \dot{w}_{n, t}+\beta_{3, i} \dot{w}_{i, t-1}+\beta_{4, i} \dot{m} w_{t}+\beta_{5, i} \dot{u} b_{t}+\beta_{6, i} \dot{P}_{t}^{c} \\
& +\beta_{7, i}(V-U)_{t-1}+\alpha_{0, i} \dot{W}_{L, t-1}+\alpha_{1, i} U R_{i} \dot{W}_{L, t-1}+\beta_{9, i} R I C_{i, t}+\varepsilon_{t}
\end{aligned}
$$

$U R_{i} \Rightarrow$ unionization rate in industry $i$.

The results of this estimation can be seen in Table $7.6 .^{51}$

The estimates for unionization variable are significant for 13 sectors. 2 of these sectors are sectors with the insignificant coefficients in Table 7.4. These are sectors 323 (Manufacture of leather and products of leather), 324 (Manufacture of footwear). In the transmission of wage changes, unions play an important role for the 13 aforementioned sectors.

Another source of wage leading and following behavior may be the product market structure. The wage changes first observed in the concentrated industries because there is a tendency of sharing the rents of monopolistic product market advantages with workers in the concentrated industries. By using this reasoning we claim that the leadership coefficients should be a function of sectoral concentration ratios as formulated in equations $\mathbf{6 . 3 3}$ and $\mathbf{6 . 3 4}$. In order to test this hypothesis, the wage leadership model is reestimated.

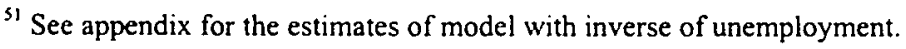




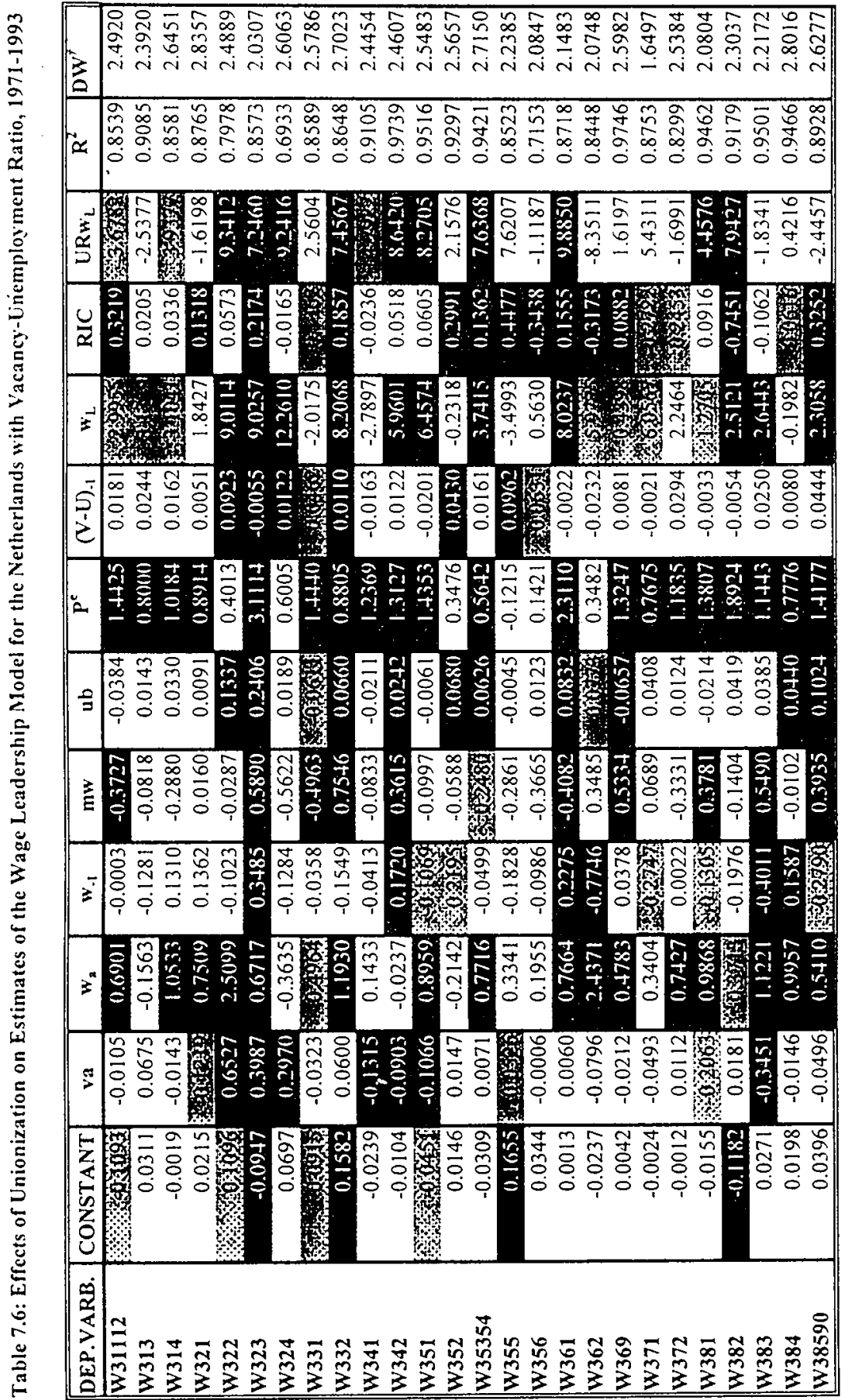

옹 


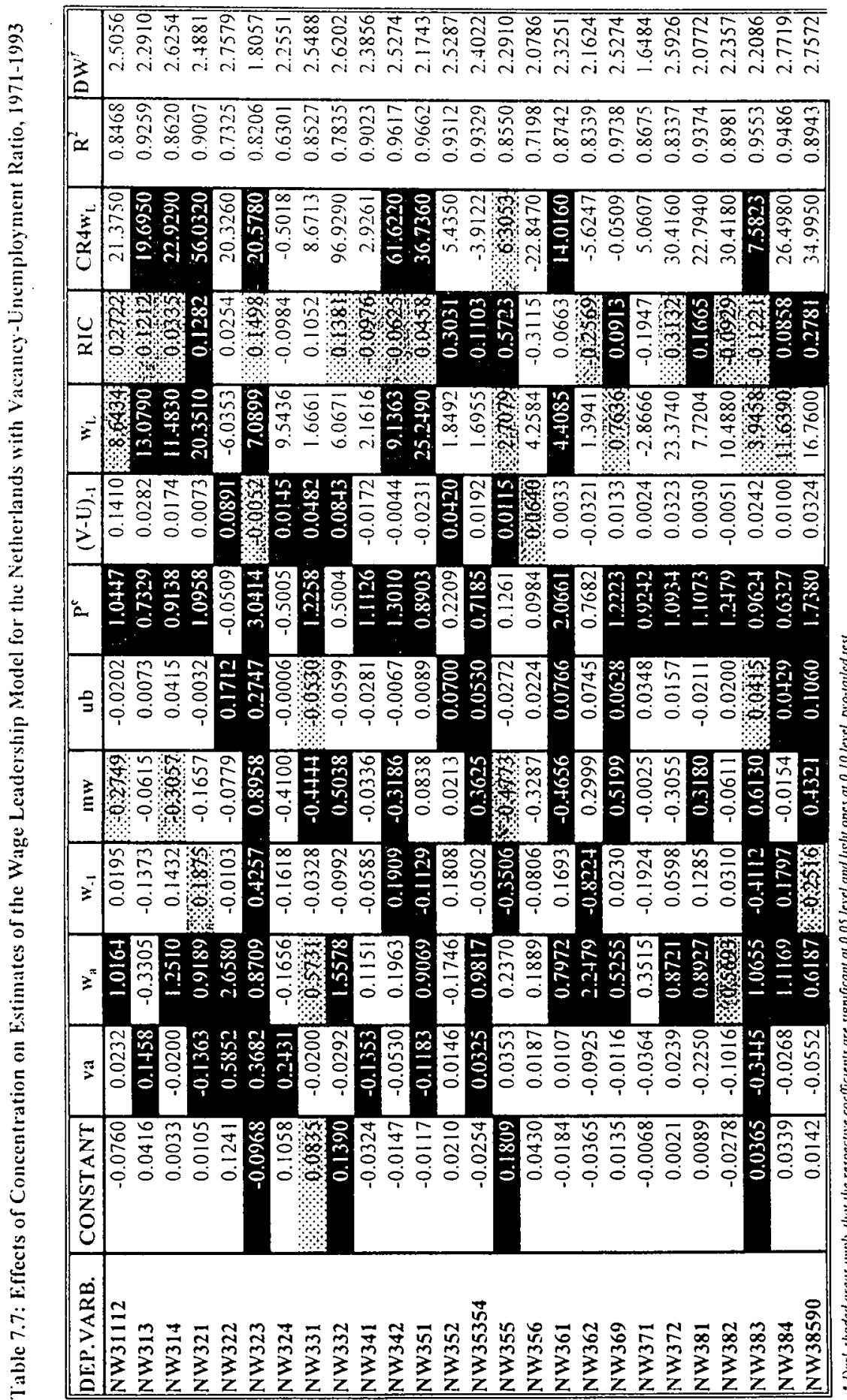


That is,

$$
\begin{aligned}
\dot{W}_{i t}= & \beta_{0}+\beta_{1, i} \dot{v} a_{i t}+\beta_{2, i} \dot{w}_{a, t}+\beta_{3, i} \dot{w}_{i, t-1}+\beta_{4, i} \dot{m} w_{t}+\beta_{5, i} \dot{u} b_{t}+\beta_{6, i} \dot{P}_{t}^{e} \\
& +\beta_{7, i}(V-U)_{t-1}+\theta_{0, i} \dot{W}_{l, t-1}+\theta_{1, i} C R 4_{i} \dot{W}_{L, t-1}+\beta_{9, i} R I C_{i, t}+\varepsilon_{t}
\end{aligned}
$$

$C R 4_{i} \Rightarrow$ four-firm concentration ratio in industry $i$.

The results of this estimation are given in Table 7.7..$^{52}$

For 9 sectors of the Dutch Manufacturing Industry, concentration ratio imposed wage leadership coefficients are significant. 2 of these sectors are sectors with insignificant coefficient in Table 7.4. These sectors are 323 (Manufacture of leather, products of leather, leather substitutes, and fur) and 355 (Manufacture of rubber products). It is possible to conclude that product market structure also plays a somewhat significant role in the transmission of wage changes from leading sectors to other sectors.

\subsection{Concluding Remarks}

In conclusion, the wage leadership model can be said to explain the growth of money wages in the Dutch Manufacturing Industry. In Table 7.4, the coefficients for 5 sectors are found to be insignificant but adding unionization and concentration variables separately to our model improves the results and the coefficients for 4 of these 5 sectors become significant, only insignificant one is sector 356 (Manufacture of plastic products not elsewhere classified). Moreover, the coefficients of unionization and concentration variables show that the wage changes are transmitted for 17 sectors of the Dutch Manufacturing Industry by either one of these channels or both as can be seen in Table 7.8. For the rest of the sectors with significant leadership coefficients, there are other channels through which wage changes are transmitted from one sector to another sector. Tests for the type of leading-following behavior in the Dutch Manufacturing Industry imply that the dominant form of wage-following behavior is weak imitation of nominal wage changes in the leading industries. To sum up, our model validates the assumptions of the wage leadership model for the Dutch Manufacturing Industry.

\footnotetext{
${ }^{52}$ See appendix for the estimates of model with inverse of unemployment.
} 
Table 7.8: Combined Effects of Unionization and Concentration

\begin{tabular}{|c|c|c|c|c|}
\hline Sector & URW & $\mathrm{CR4W}_{\mathrm{L}}$ & Both & None \\
\hline 31112 & + & & & \\
\hline 313 & & + & & \\
\hline 314 & & & + & \\
\hline 321 & & + & & \\
\hline 322 & + & & & \\
\hline 323 & & & + & \\
\hline 324 & + & & & \\
\hline 331 & & & & + \\
\hline 332 & + & & & \\
\hline 341 & + & & & \\
\hline 342 & & & + & \\
\hline 351 & & & + & \\
\hline 352 & & & & + \\
\hline 35354 & + & & & \\
\hline 355 & & + & & \\
\hline 356 & & & & + \\
\hline 361 & & & + & \\
\hline 362 & & & & + \\
\hline 369 & & & & + \\
\hline 371 & & & & + \\
\hline 372 & & & & + \\
\hline 381 & + & & & \\
\hline 382 & + & & & \\
\hline 383 & & + & & \\
\hline 384 & & & & + \\
\hline 38590 & & & & + \\
\hline Total & 8 & 4 & 5 & 9 \\
\hline
\end{tabular}

Graafland and Verbruggen (1993) found that in the Dutch economy wage leading sectors are mainly manufacturing sectors although manufacturing consists around one fifth of total employment in the Netherlands. The wage leading sectors of Graafland and Verbruggen (1993) are food processing, wood and building materials, paper and printing and the chemical industries, and a one service sector, banking and insurance. Our study is focused on the wage dependencies in the manufacturing sector because of the problems related with the data and our model does not permit us to include other sectors with the existing data. However, our findings, in general, do not diverge completely from the findings of Graafland and Verbruggen (1993). Both the paper and printing and chemical industries are also found as wage leaders by our study. The food industry is treated as an aggregate of four subsectors of our study in 
Graafland and Verbruggen (1993). In fact, one of these subsectors may well be a candidate of being a wage leader (313-Beverage Industries) as observed in Table 7.2. Thus, the difference related with this sector may be related with the disaggregation. Our data shows that this industry is a high-wage industry and it has the highest average wage rate change among the food industries. The most significant difference is in the case of wood industries. In sum, the analysis of wage-leading behavior in a different setting for the whole Dutch economy is a concern of future research.

Graafland and Verbruggen (1993:1381) find that wage formation in the aggregated wage-leading sector both depends on the wage rate in the wage-leading sector and on macro variables. Table 7.4 also exhibits a difference in this respect. Our findings show that the rate of growth of wages in the wage-leading sectors are affected rather by the sector-specific variables, like value added, and average wages in the wage-leading sectors. In this respect, labor market tightness, unemployment benefits and minimum wages are not significant. However, such differences are acceptable since Graafland and Verbruggen (1993) is concentrated on the wage formation for the whole Dutch economy. The existing similarities, on the other hand, verify that our study is on the right way. 


\section{APPENDIX 7A: THE COMPLETE WAGE LEADERSHIP MODEL}

The complete wage leadership model is

$$
\begin{aligned}
\dot{W}_{i t} & =\beta_{0}+\beta_{1, i} \dot{v} a_{i t}+\beta_{2, i} \dot{w}_{a, t}+\beta_{3, i} \dot{w}_{i, t-1}+\beta_{4, i} \dot{m} w_{t}+\beta_{s, i} \dot{u} b_{t}+\beta_{6 . i} \dot{P}_{t}^{e} \\
& +\beta_{7, i}(V-U)_{t-1}+\beta_{8 . i} \dot{W}_{L, t-1}+\beta_{9, i} R I C_{i, t}+\beta_{10, i} \Pi_{i, t-1}+\beta_{11, i} \dot{w} d_{i, t-1} \varepsilon_{t}
\end{aligned}
$$

$\Pi_{i} \Rightarrow$ profitability measure for industry $i$.

$\dot{w} d_{i} \Rightarrow$ wage drift in industry $i$.

One of the additions to the model is the sectoral profitability measure. The addition of this variable is mainly related to the efficiency wage concerns. In its simplest version, efficiency wage theory can be formulated as follows: if the productivity of workers depends on the wage, an excess supply of labor may not provide firms to cut wages, since in doing so the reduction in productivity may outweigh the savings made by paying lower wages, thereby actually increasing unit labor costs. The efficiency wage is the wage which minimizes wage costs per efficiency unit. A potential explanation for the relationship between product market power measured by the profitability and wages is complementarity between capital and unobserved skills. This link relies on a view that capital-intensive industries are likely to be more concentrated and typically more likely to generate monopoly rents for incumbent firms. The union threat model and some other models in which insider workers have bargaining power imply that workers should share in product market rents in the form of higher wages. The same relationship arises from efficiency wage models in which workers' notions of fairness are related to the firms' ability to pay. Moreover, the rent sharing explanations are closely related with the efficiency wage theories in two senses. First, the reasoning of firms in sharing rents is likely that failure to do so will result in their work force not cooperating with firms by quitting, or shirking. By paying a higher wage, firms may invoke effort and avoid these consequences. Second, rent sharing is less expensive for firms in an efficiency wage environment where changes in wages have no first order effect on costs than it would be in a standard competitive situation. Kahneman, Knetsch, and Thaler (1985) provided evidence from the Canadian labor market that for many worker fair wages for incumbent employees depend on a firm's profitability and ability to pay. Kumar (1972), Pugel (1980) and Hodson and England (1986) found strong positive effects of industrial profitability measures on average industry wage changes. In the formulation 
of the profitability measure, the nominal profits are divided by the nominal gross additions to fixed assets during the year and lagged one year since adapting the change in profits is time related concept and in the bargainings to take into account the previous periods' profits is more likely to occur.

Another addition is the wage drift. The essence of wage drift is that the effective rate of wage per unit of labor input is raised by the arrangements that lie outside the control of the recognized procedures for contract rates. These procedures issue in awards, statutory orders, or negotiated agreements that place time-rates or piece-rates, or changes in them throughout a field of employment. But during a period in which unchanged contract rates continue to apply, the rates actually being paid for a given labor input may rise. This rise may come about in several ways. The employer may directly agree with an individual worker or a group for a higher rate than that contracted, or where the contract rate is preserved he may raise the effective rate by arranging overtime, loosening standards of grading and payment by results, and providing different kinds of bonus and benefits. In these ways, the contracted wage rates is replaced by variations made locally, and they obviously lie within drift.

The factors behind the wage drift can be grouped under three headings in the literature; sex, skill, and industry specific factors. Lerner and Marquand (1962) pointed out that female workers get less overtime and fewer long service and merit changes than male workers and that they have been less able to get a share from the wage drift. Turner and Jackson (1969) stated that female workers are unlikely to have benefited much from the upgrading of workers resulting from technological progress because they are generally confined to relatively unskilled jobs, and their employment on shifts is restricted.

The second source of drift is the skill of the workers. Brown (1962) observed a higher drift for the skilled workers than for the unskilled ones by using the Scandinavian data. Behrend (1960) also found similar results with the Scottish data. Skilled workers may reveal more drift since they are scarcer than unskilled workers in the labor market.

Finally, there are industry specific factors at work. The differences between industries in the extent of drift show some relation with their prosperity as found by Dicks-Mireaux (1958) for Sweden and Marquand (1960) for Britain. In these studies, it is observed that the larger the size of the firm, the larger the extent of wage drift. The main cause of the wage drift is attempts to offset reductions in vertical inequality 
amongst workers. In a study of Dutch manufacturing industry, Driehuis (1975) found the main determinants of wage drift as changes in productivity and changes in the degree of unionization

In fact, the size of the wage drift may reflect union equity objectives. This influence has generally been seen in countries with centralized collective bargaining systems such as in the Scandinavian countries (Dicks-Mireaux,1958 and Brown, 1962), the Netherlands before 1969 (Driehuis,1975) in which attempts by the labor movement to achieve greater equality in the structure of negotiated wage rates impeded by the subsequent behavior of the drift. Therefore, available evidence suggests the introduction of a variable taking into account the impact of wage drift. In the model, one period lagged change in wage drift $(w d)$, that is the difference between actual wages paid and contract wages, is used. Therefore, contract wages are added as an explanatory variable and lagged one.period since its extent affects the wage negotiations held in the next year.

The expected signs of these variables are discussed as follows:

- Profitability $(\pi)$ : This variable is included in accordance with the presuppositions of the efficiency wage theory. If the expectations of efficiency wage theory in terms of rent-sharing are well-founded, the sign of the coefficient on the profitability variable should be positive.

- Wage Drift (wd): This variable is calculated as the difference between the real hourly contract wages and the real wages actually paid. It measures the effects of this difference on the percentage change of next periods' real hourly contract wages. Its coefficient is expected to be positive especially because of unions' equity considerations. 


\section{APPENDIX 7B: THE DUTCH DATA}

In this section of the study, the data sources for the Netherlands will be explained in a detailed manner variable by variable.

The Dutch data covers the period 1970-1993. In order to reach to real variables, the price indices with the base year of 1990 are used. The data sources and the description of the data are as follows:

- Wage Data: Both nominal and real wages are average hourly wages paid. It is calculated by using the gross earnings that include pay for normal time and merit pay; supplements and bonuses for overtime, shift work or irregular hours; commissions; rent subsidies; payment for time spent for traveling; bonuses and premiums regularly paid at each period; remuneration for time not worked such as public holidays, annual leave or short absences; short time wages and salaries and wages and salaries paid in the event of sickness or accident, provided the gross amount continues to be paid in full (ILO,1995:149). They exclude employer's contribution to health insurance; holiday bonuses; performance-related payments, incentive pay, profit-sharing or asset-formation payments when they are paid on an irregular basis; compensation for transport costs, tools, working clothes, and use of private car, etc.; interest subsidies on amounts borrowed from the employer; advances and back-pay; other incidental and occasional payments; payments and/or supplements paid in the event of sickness, accident or reduced hours of work, unless the employer continues to pay the entire gross wage or salary. The data is obtained from Yearbooks of Labor Statistics of International Labor Organization (ILO). However, the origin of the data is Jaarlyks Loonenderzoek (Annual Earnings Survey) of Central Bureau voor de Statistiek (Central Bureau of Statistics-CBS). The reference period of this data is $1^{\text {st }}$ of October and it covers all the establishments for the whole country.

- Value Added (va): It is obtained from the Structural Analysis Industrial Database (STAN) of Organization for Economic Cooperation and Development (OECD). It is an estimated database. It is national accounts compatible value added, represents the contribution of each industry to national GDP (OECD,1995b:10). The value added per worker is calculated and deflated by the sectoral producers' price indices (excluding Value Added Tax-VAT) whose base year is 1990 that are 
obtained from CBS. However, the indices used are available for 2-digit ISIC classification. The employment figures comprises number of employees as well as self-employed, owner proprietors, and unpaid family workers.

- Minimum Wage ( $\mathrm{mw}$ ): It is the monthly minimum wage paid and obtained from CBS. If there is a change in the minimum wage paid during the years, the simple average of these values are used.

- Unemployment Benefits (ub): It is the total amount of annual unemployment benefits and covers the actually paid inclusive supplements. It is also obtained from CBS.

- Expected Rate of Growth in the Price Level $\left(\mathbf{P}^{\mathbf{e}}\right)$ : The expected rate of growth in consumer price index (CPI) is used. Price changes are assumed to influence workers in all sectors equally. It is the simple average of past, present, and future CPI. The data on CPI whose base year is 1990 that includes the VAT is obtained from CBS.

- Vacancy Rate (V): It is the annual amount of reported vacancies in the economy (demand of employers) and obtained from CBS.

- Unemployment Rate (U): It is the rate for the registered unemployed which comprises all persons between the ages of 16 and 64 registered at the employment exchange who do not work or are working fewer than 12 hours per week and have found work bringing the total number of weekly working hours to at least 12 hours, or declare they want to work at least 12 hours per week, are available to accept work at least 12 hours per week.

- International Trade Data(Exports and Imports): This data is obtained from OECD's Compatible Trade and Production (COMTAP) database which contains flows by ISIC, Revision 2 category. The data have been converted from the Standard International Trade Classification (SITC), Revision 1, 2, and 3 depending upon the year concerned. The conversion from the SITC commodity classification to the ISIC industry classification is not exact because many SITC commodities can be produced by two or more ISIC industries. OECD developed a conversion table that distributes a fixed percentage of each multi-industry commodity to a corresponding ISIC industry. Due to the inexactness of this conversion process the aggregation of lower level ISIC industries may not be equivalent to the higher levels of ISIC. 
- Concentration Ratio (CR4): It is the sectoral concentration ratios in terms of four largest firms' sales. The data on this variable comes from two sources. For the period 1974-1986, the data is provided by Marcel Lever from EIM Small Business Research and Consultancy. For the period 1970-1973, by using an approximation method -taking averages of EIM's data in the backward direction-, it is calculated. After 1986, by using CBS data on establishment sizes and the method introduced by Bain (1966:27-30), it is constructed.

- Unionization Rate (UR): Union coverage in some sector is defined as the number of employees covered by a collective agreement divided by the total number of employees in that sector. This data is also provided by Marcel Lever from EIM Small Business Research and Consultancy for the period 1974-1992. He obtains the data on the number of workers covered by the collective agreements, which are not published at low aggregation levels, from the Ministry of Social Affairs and Employment. By registration, which is enforced by law, the Ministry classifies around 200 industry agreements according to the 3 -digit industries. The numbers of workers covered by industry agreements include those that are covered by mandatory extension. Sectoral data on the total number of employees are obtained from CBS. As put forward by Lever and Marquering (1995:15-16), in practice, there are some problems with the data of covered employees. Firstly, collective agreements often apply to several 3-digit industries; the agreement for the manufacture of metal products even applies to several 2-digit industries. Secondly, some agreements are not correctly classified to the 3-digit industries. Thirdly, the numbers of covered employees appear to be rounded. Fourthly, there may be some lags in the adjustment of the number of covered employees. Finally, there appears to be some overreporting of the number of workers covered, as union coverage is sometimes greater than unity. These problems are dealt with as follows by Lever and Marquering (1995:16). Firstly, union coverage is computed for 2-digit industries in the manufacturing sector. This level of aggregation is high enough to be able to classify the agreements and to reduce the impact of misclassification and of the rounding of the number of covered workers. The level of aggregation is low enough to obtain an acceptable number of observations. Secondly, union coverage is computed for a period of more than 20 years, which is long enough to reduce the impact of eventual lags in adjusting the number of 
covered workers. Finally, it is assumed that the reported change in the union coverage corresponds to the actual change. 
$\frac{2}{\frac{2}{5}}$

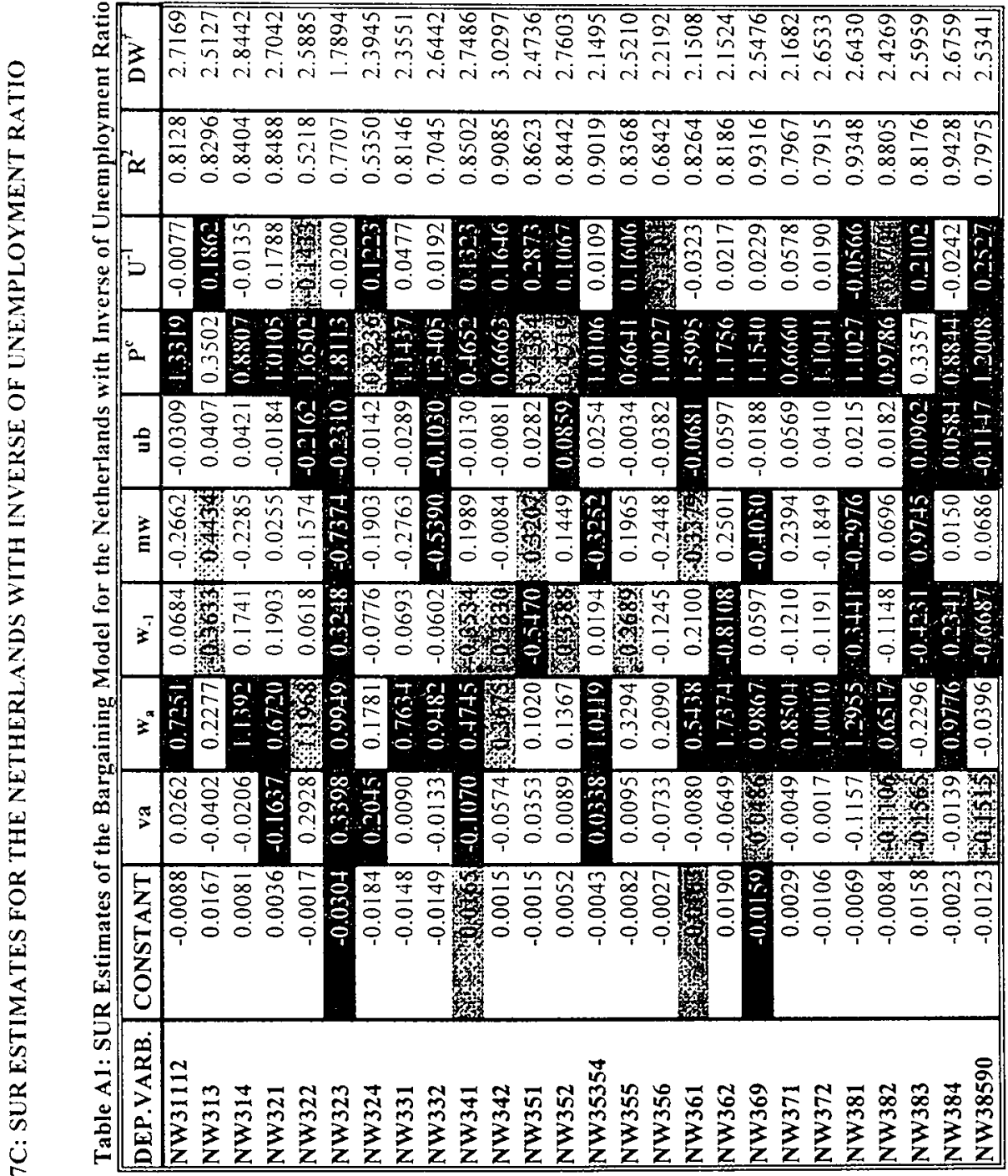




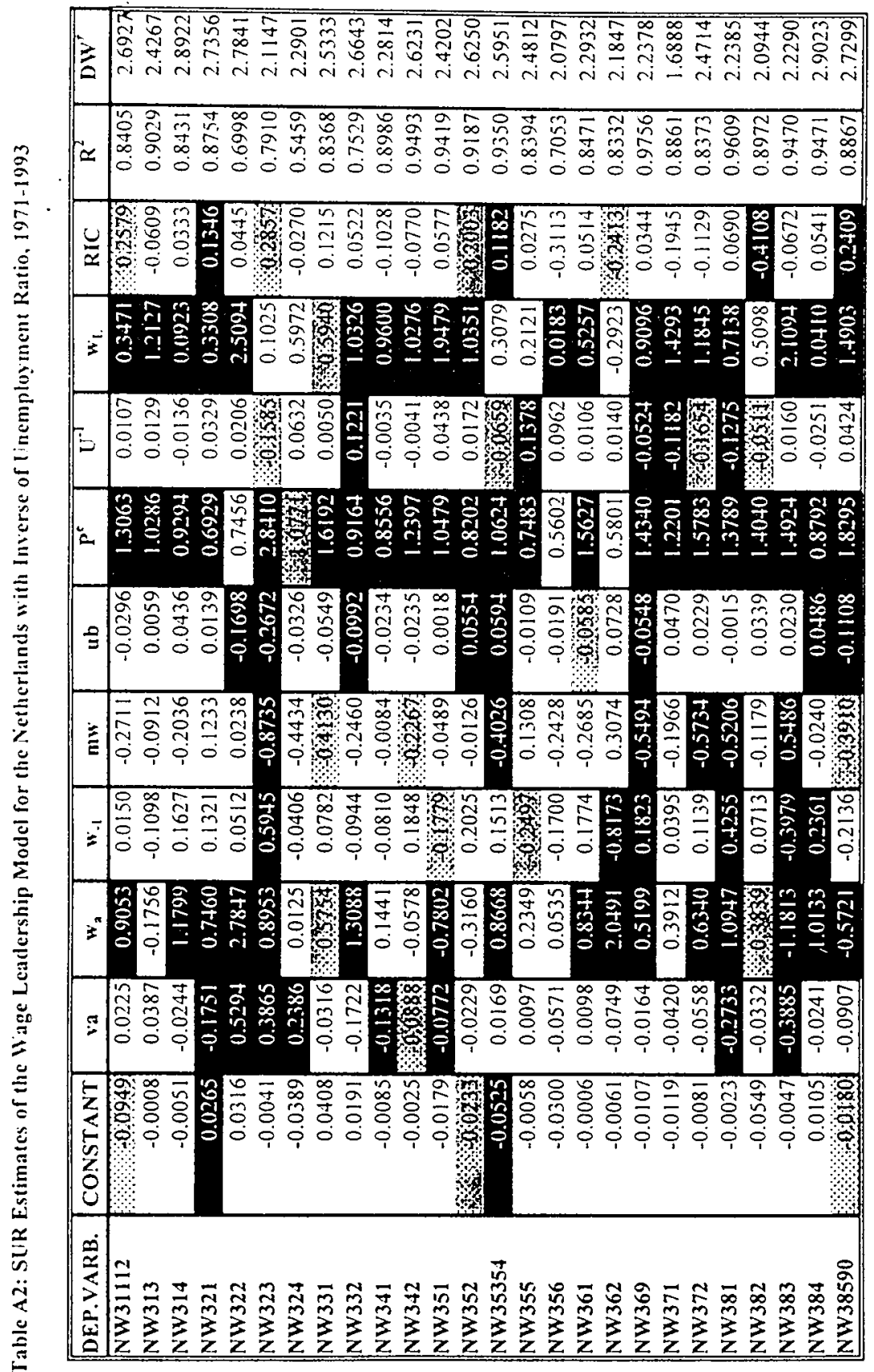




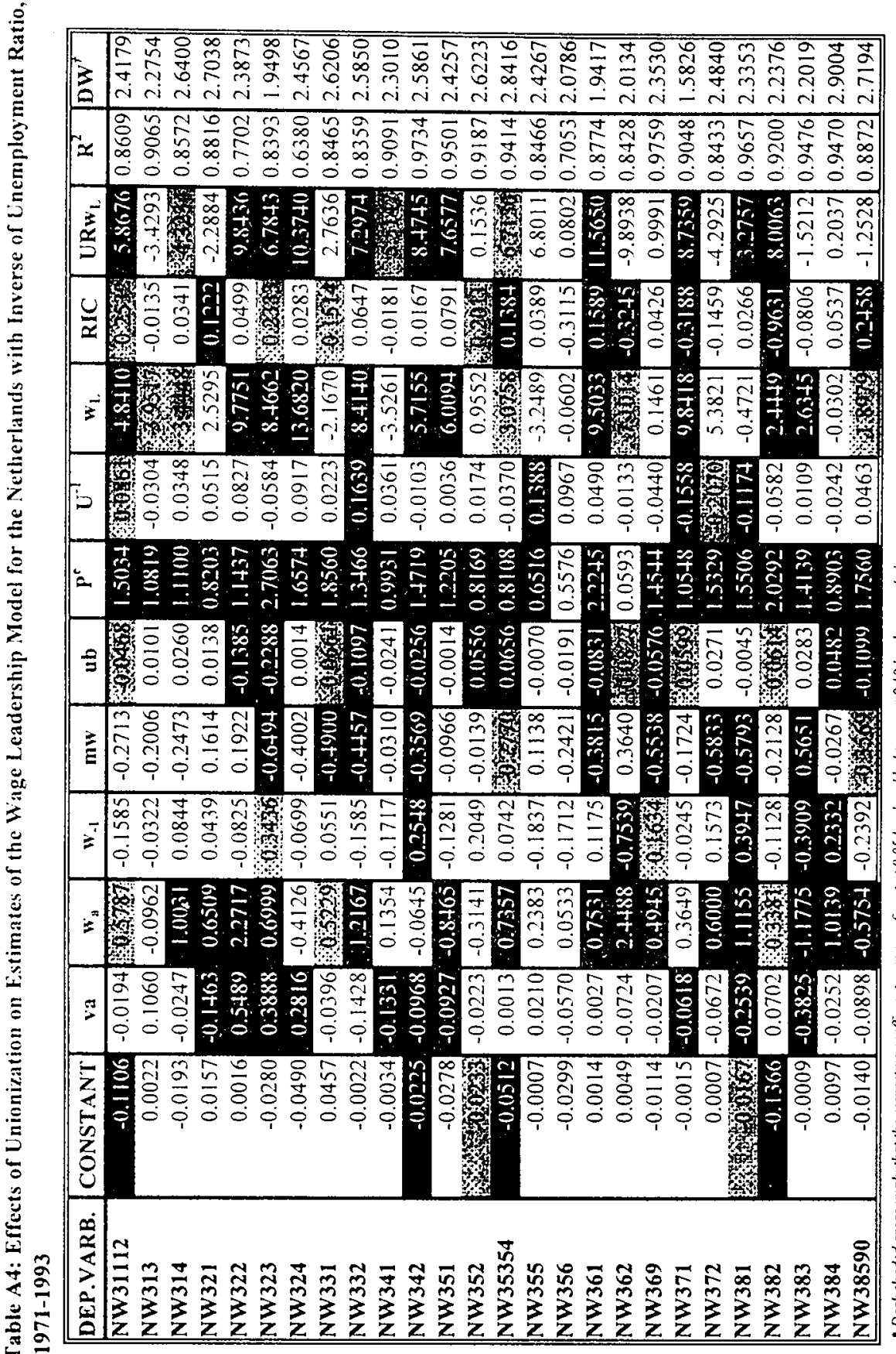

$\widetilde{N}$ 


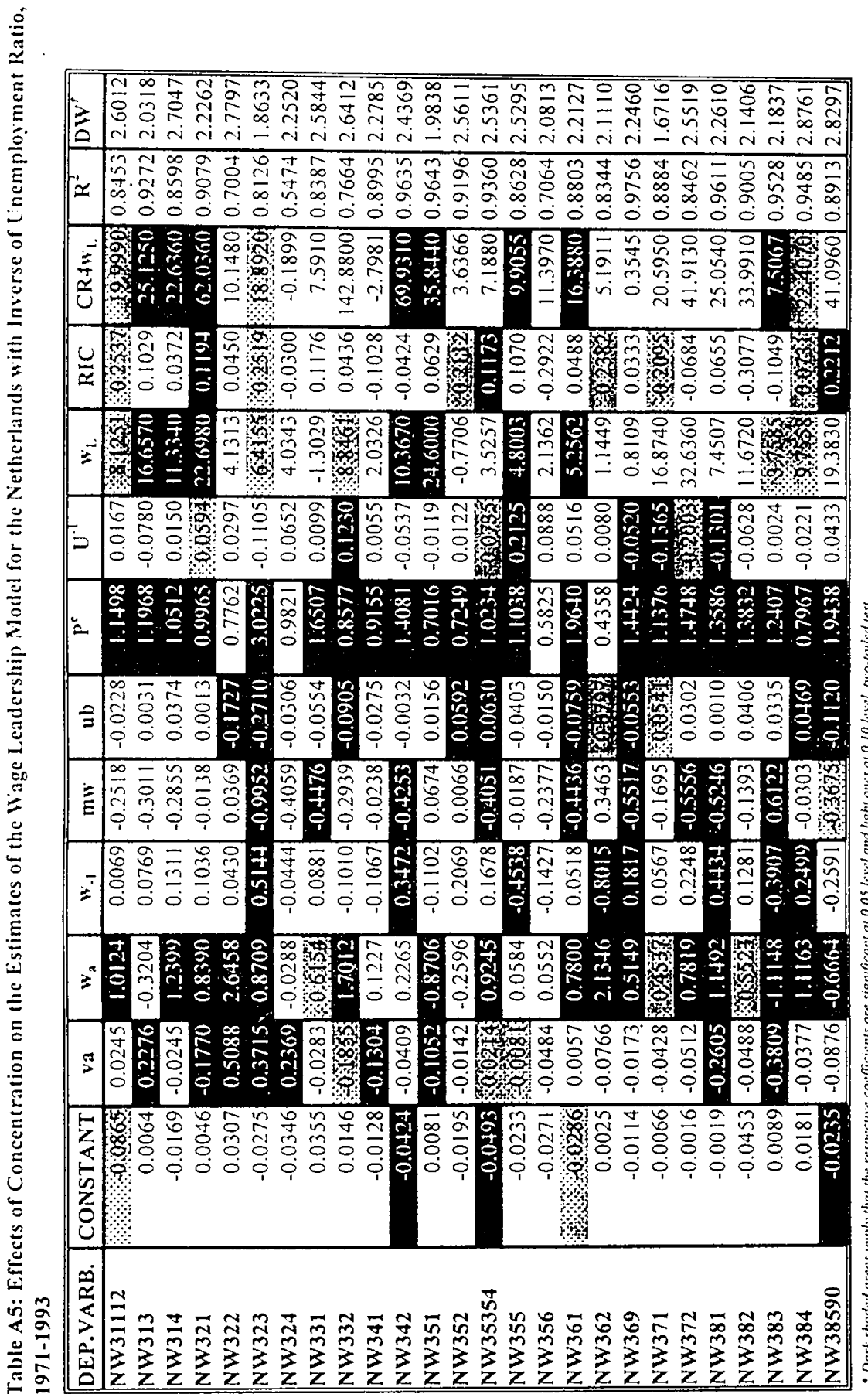




\section{WAGE DETERMINATION PROCESS IN TURKISH}

\section{MANUFACTURING INDUSTRY}

\subsection{Introduction}

This chapter of the study deals with the determinants of wages in the Turkish manufacturing industry. The order of the sections is same as in the Dutch case with minor differences. The regressions with vacancy-unemployment ratio cannot be estimated for the Turkish case since the data on vacancy rates is only available for Turkey after 1980. Therefore, analysis will be carried out by using the estimates of a Philips-type equation. The second difference with the Dutch case refers to the fact that an unemployment benefit scheme is absent in the Turkish labor market, therefore this variable is dropped from the equations. The estimation method will again be SUR but for Turkish case there are 29 manufacturing sectors, in other words a system with 29 equations is estimated. We first discuss the bargaining model.

\subsection{A Bargaining Model of Wage Inflation}

The bargaining model expressed in chapter 6 is estimated for Turkish manufacturing industry. The estimated equation is ${ }^{53}$

(8.1) $\dot{w}_{i t}=\beta_{0}+\beta_{1, i} \dot{v} a_{i t}+\beta_{2, i} \dot{w}_{a, t}+\beta_{3, i} \dot{w}_{i, t-1}+\beta_{4, i} \dot{m}_{w}+\beta_{5, i} \dot{P}_{t}^{e}+\beta_{6, i} U_{t-1}^{-1}+\varepsilon_{t}$

where $i=1, \ldots, 29, t=1971, \ldots, 1994, \varepsilon_{t} \sim N\left(0, \sigma^{2}\right)$, all relevant variables are in the rate of growth and

$W_{i} \Rightarrow$ nominal hourly wages in industry $i$,

$v a_{i} \Rightarrow$ real value added per hour in industry $i$,

$w_{a} \Rightarrow$ alternative wages set,

$w_{i} \Rightarrow$ real hourly wages in industry $i$,

$m w \Rightarrow$ real minimum wage paid in the economy,

$P e \Rightarrow$ expected prices,

$U^{-l} \Rightarrow$ inverse of unemployment rate.

The estimation results are given by Table 8.1 .

${ }^{53}$ The discussion of the expected signs given in chapter 7 is also valid for Turkish case. 
The labor productivity variable, growth rate of value added, is significantly related with the growth rate of money wages in only 10 sectors. What is more interesting is the existence of a negative relation between these two variables in 3 of the industries with significant coefficients. Therefore, the changes in the rate of productivity growth do not generally explain the changes in the rate of growth of money wages and the signs of some significant estimates are against the predictions of the bargaining theory.

For the Turkish manufacturing industry, we have two variables on the opportunity cost of labor, alternative wage set and minimum wages. In 16 out of 29 sectors, the coefficients for alternative wage set are significant with positive signs as expected, the only exception is sector 369 (Manufacture of other non-metallic mineral products) with a negative sign.

Moreover, minimum wage variable is significant in 12 sectors. These two variables have a significant effect in 24 sectors in the explanation of the growth rate of money wages. Therefore, it is possible to claim that opportunity cost is an important variable in the determination of money wage changes.

The coefficients of past real wage changes strongly confirm the presuppositions of real wage adjustment lag hypothesis. Only one coefficient is insignificant and all the significant coefficients have positive sign.

Price expectations are also an extremely important factor in the determination of money wages changes. In all industries, the coefficients of this variable are significant and positive.

The final important result from Table 8.1 is the disapproval of Philips-type relation in Turkish manufacturing industry. Only in 5 industries, the coefficient of this variable is significant and negative as expected.

In conclusion, we can claim that bargaining model is successful to some extent in explaining the growth rate of money wages in Turkish manufacturing industry. The only exception against this statement is the insignificant results on the productivity variable which is, however, the main tenet of the bargaining model. The reason of such a result is that growth rate of value added may not be a good approximation of productivity. In the next section, we explore the impact of institutional processes on wage determination. 


\subsection{The Wage Leadership Model}

Our next step is to identify the wage leading and following sectors in the Turkish manufacturing industry and then to examine the interdependence in the sectoral wage formation. In order to determine the wage leading and following sectors again the modified Sims method of equation 6.28 is utilized. The equation is given as

(8.2) $\dot{W}_{N_{i, t}}=\beta_{0}+\beta_{l, i} \dot{W}_{N_{i, t-1}}+\beta_{2, i} \dot{W}_{N_{i, t-2}}+\beta_{3, i} \dot{W}_{L_{i, t}}+\beta_{4, i} \dot{W}_{L_{i, t-1}}+\beta_{5, i} \dot{W}_{L_{i, t-2}}$

$$
+\beta_{6, i} \dot{W}_{L_{i, t+1}}+\beta_{7, i} \dot{W}_{L_{i, t}+2}+u_{t}
$$

where $i=1, \ldots, 29, t=1971, \ldots, 1994$, and $u_{t} \sim \mathrm{N}\left(0, \sigma^{2}\right)$,

$W_{L} \Rightarrow$ percentage change in the hourly wage rate of the leading sectors,

$W_{N} \rightarrow$ percentage change in the hourly wage rate of the following sectors.

Wald tests of $\beta_{6}+\beta_{7}>0$ are carried out. The detailed results are presented at Tables $8.2 \mathrm{a}, 8.2 \mathrm{~b}$, and 8.2 below.

Sectors 311 (Food Manufacturing) and sector 353 (Petroleum Refineries) are identified as the wage leading sectors for the Turkish manufacturing industry by Wald tests. Sector 311 has 23 following industries and no leader industry at $5 \%$ significance level. On the other hand, sector 353 has 19 following industries and only one leading industry which is sector 311 . For the reader who is familiar with the Turkish case, finding Sector 311, which may be thought as characterized by small private producers, as wage leader may be surprising. However, such an approach may be misleading since this sector also includes sugar industries subsector characterized by large public sector firms until recently and it has a considerable weight in terms of value added and employment. Moreover, Erdil (1996b) observes that wage contracts signed by the public sector is seemed to be imitated by the private sector in Turkey.

As another step, we test the unidirectional causality implied by the wage leadership hypothesis. In fact, this test provides a proof of what we have done in the previous step. 


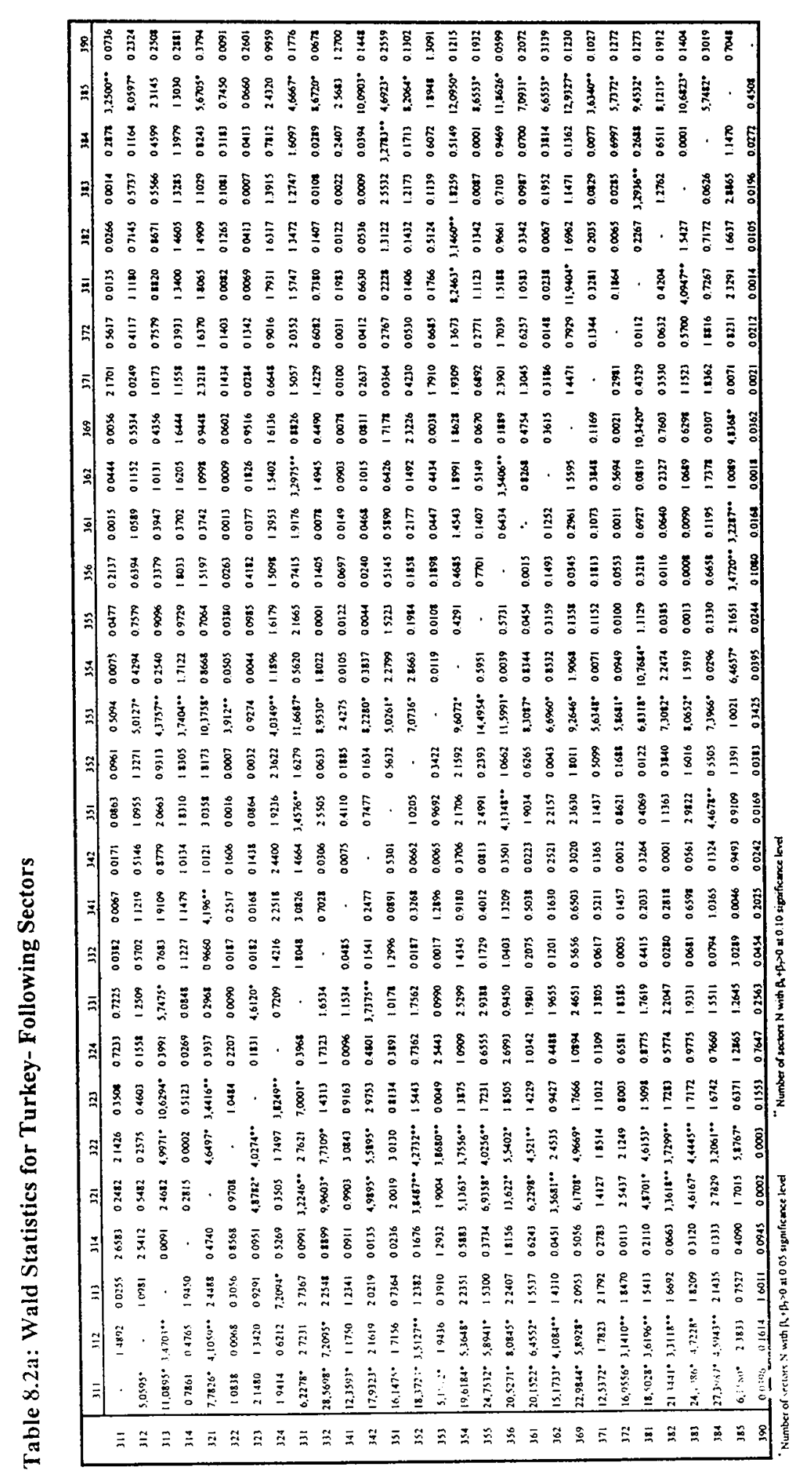

ิำ 


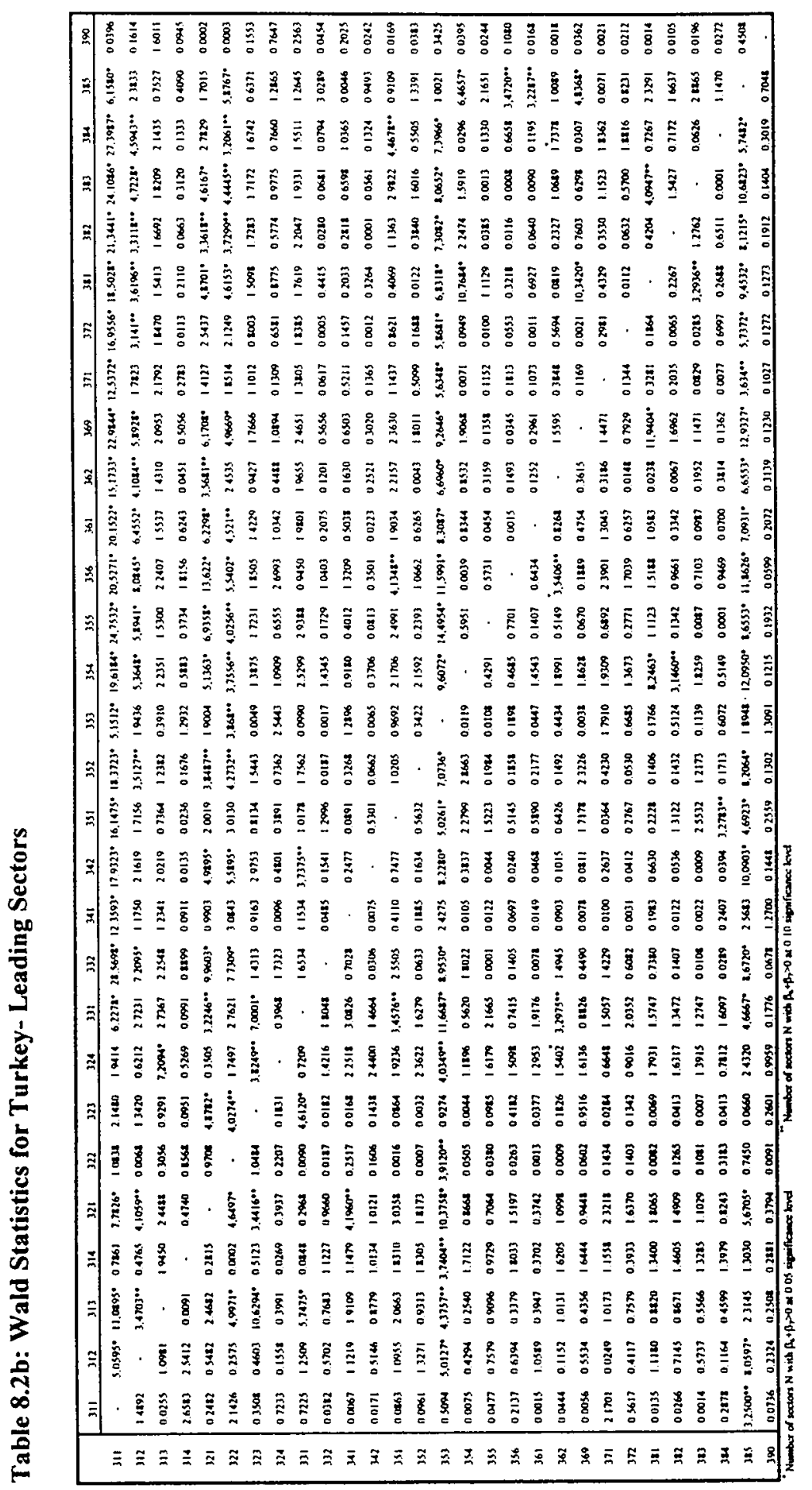

옥 


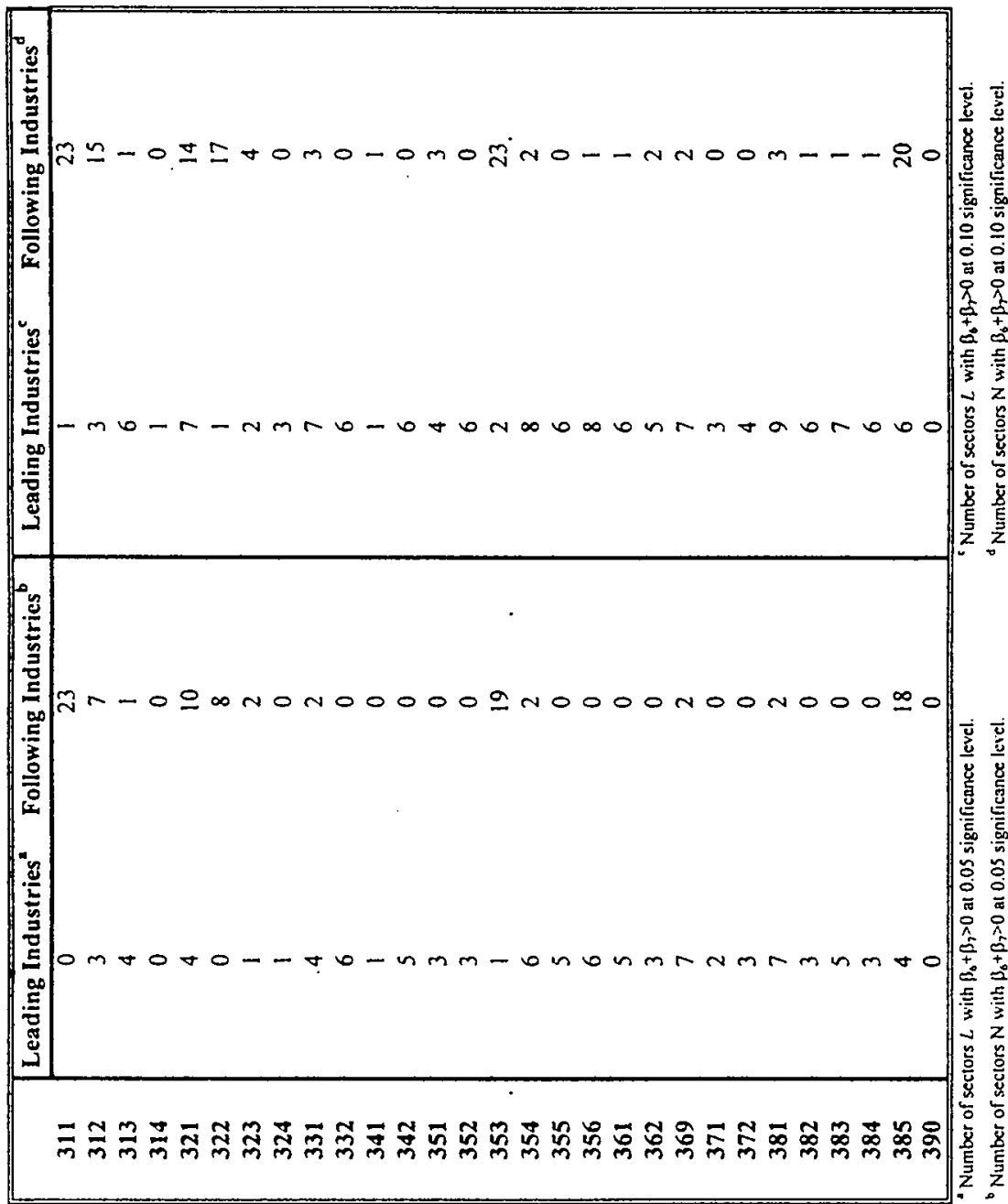


To carry out the tests of unidirectional causality, Granger test supplied by equation 6.36 is utilized.

$$
\text { (8.3) } \dot{W}_{L, i, t}=\gamma_{0, i}+\gamma_{1, i} T+\gamma_{2, i} \dot{W}_{L_{i, t-1}}+\gamma_{3, i} \dot{W}_{N_{i, t-1}}+\eta_{t}
$$

where $T$ is a linear time trend which is included in the regression to make the series stationary. 54

The hypothesis to be tested is,

(8.4) $H_{0}: \gamma_{3, i}=0$

$$
H_{1}: \gamma_{3, i} \neq 0
$$

Table 8.3: Granger Causality Results for Turkey

\begin{tabular}{|l|c|}
\hline DEP.VARB. & $W_{\text {N-1 }}$ \\
\hline WL311 & 0.0458 \\
WL312 & -0.0077 \\
WL313 & 0.0625 \\
WL314 & -0.0369 \\
WL321 & 0.0182 \\
WL322 & 0.3601 \\
WL323 & 0.0683 \\
WL324 & -0.0470 \\
WL331 & -0.0141 \\
WL332 & 0.0340 \\
WL341 & 0.0253 \\
WL342 & 0.0414 \\
WL351 & 0.0425 \\
WL352 & 0.0343 \\
WL353 & -0.1097 \\
WL354 & 0.0137 \\
WL355 & 0.4499 \\
WL356 & 0.0312 \\
WL361 & 0.0317 \\
WL362 & 0.0517 \\
WL369 & 0.0304 \\
WL371 & 0.0647 \\
WL372 & 0.0445 \\
WL381 & 0.0495 \\
WL382 & 0.0501 \\
WL383 & 0.0354 \\
WL384 & 0.0365 \\
WL385 & 0.1147 \\
WL390 & -0.0022 \\
\hline \hline
\end{tabular}

- Dark shaded areas imply that the respective coefficients are significant at 0.05 level.

\footnotetext{
${ }^{54}$ Adding time trend seems to be necessary also for Turkish case as a result of the unit root tests.
} 
If the coefficients in equation 8.4 are found to be insignificant, this implies that the wage increases in the nonleading sectors do not cause wage increases in the leading sectors. The results of Granger causality tests can be seen in Table 8.3.

There are 3 significant test results in Table 8.3, namely sector 322 (Manufacture of Wearing Appare1), sector 355 (Manufacture of Rubber Products), and sector 385 (Manufacture of Professional and Scientific and Measuring and Controlling Equipment Optical Goods). If we analyze Table 8.2 and Table 8.3 together, we see that sector 322 and sector 355 can be considered to behave out of the wage leading and following way. Only sector 385 is a violation to our predictions but in fact this sector might also be considered as a third wage leading sector in Turkish manufacturing industry with 18 follower and 4 leaders. Therefore, this violation is not a strong enough to be a critical point for the wage leadership hypothesis and it can be neglected without hesitation.

Following the determination of wage leading industries for the Turkish manufacturing industry, the estimation of the wage leadership model is the next step in the analysis of the wage determination process. The wage leadership variable which is designed by weighting the growth rate of wages in the leading sectors is added to the bargaining model of equation 8.1. Furthermore, the variable called as ratio of international competitiveness is also added to the model. For Turkey, we believe in the fact that it helps to capture the effects of liberal free trade policies on wages after 1980 .

The estimating equation is

$$
\begin{aligned}
\dot{W}_{i t} & =\beta_{0}+\beta_{1, i} \dot{v} a_{i t}+\beta_{2, i} \dot{w}_{a, t}+\beta_{3, i} \dot{w}_{i, l-1}+\beta_{4, i} \dot{m} w_{t}+\beta_{5, i} \dot{P}_{t}^{e}+\beta_{6, i} U_{t-1}^{-1} \\
& +\beta_{7, i} \dot{W}_{L, t-1}+\beta_{8, i} R I C_{t}+\varepsilon_{l}
\end{aligned}
$$

$W_{L} \Rightarrow$ percentage change in the hourly wage rate of the leading sectors, $R I C_{i} \Rightarrow$ ratio of international competitiveness for sector $i$.

The estimation results of this system of equations are presented in Table 8.4.

If Table 8.1 and Table 8.4 is compared, we observe improvements for some market variables. The most significant change occurred in the coefficients for the opportunity cost variables. These variables are together significant in all industries according to the Table 8.4. The change in productivity variable is really slight, 11 out of 29 coefficients are significant and only 7 of them have positive coefficients. 
However, the performance of the rest of market variables adversely affected by the introduction of the wage leadership variable. There is a change in the labor market tightness (unemployment) variable. It is now significant for 6 sectors. This means that when workers' wage comparisons with wage leading sectors are taken into account, unemployment gains more importance in the wage determination process. Another change is found in the expected price variable. The number of significant coefficients falls from 29 to 28 .

The wage leadership variable performs excellently. In 28 sectors, its coefficient is significant and positive and this corroborates the wage leadership hypothesis.

Therefore, the growth of money wages is determined as a result of the wage comparisons with the wages realized in the wage leading sectors. This result adduces the predictions of the wage leadership model. Finally, the international trade variable gives significant results for 11 sectors. Moreover, in 8 of these industries, its coefficient is positive denoting that competitiveness in the international markets brings about the utilization of skilled labor that necessarily implies a higher growth rate in wages. The negative signs belong to sectors 323 (Manufacture of leather, products of leather, leather substitutes, and fur), 324 (Manufacture of footwear), and 372 (Non-ferrous basic metal industries) implying that competitiveness in the world markets requires lower labor costs.

The detailed examination of the behavior of wage leadership coefficients is the next step in the analysis. In order to test the type of imitation of wage changes by following sectors -whether there is a weak or precise imitation, two hypotheses are proposed. These hypotheses are tested by usual t-statistics.

(8.6) $H_{0}: \beta_{8, i}>0$

and

(8.7) $H_{0}: \beta_{8, i}=I$

The results of these tests are submitted in Table 8.5 . 
Table 8.5: Tests of Wage Leadership Hypothesis for Turkey with Inverse of Unemployment Ratio, 1971-1994

\begin{tabular}{|c|c|c|}
\hline DEP.VARB. & $W_{L}>0$ & $w_{L}=1$ \\
\hline NW311 & - 2.6086 & 1.2518 \\
\hline NW312 & 2.7440 & 7.5326 \\
\hline NW313 & 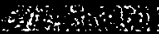 & $y^{2} i^{2}:$ \\
\hline NW314 & 3.5987 & 13.1401 \\
\hline NW321 & 1.8203 & 12.13321 \\
\hline NW322 & 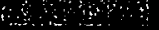 & 30.4491 \\
\hline NW323 & 1.7650 & 14.4582 \\
\hline NW324 & 2.1348 & 1.3396 \\
\hline NW331 & 2.5500 & 7.2043 \\
\hline NW332 & 1.8972 & 7.8023 \\
\hline NW341 & 1.8797 & .7232 \\
\hline NW342 & 1.7576 & 9.4752 \\
\hline NW351 & 1.8647 & 9.5942 \\
\hline NW352 & 1.8339 & 17.5200 \\
\hline NW353 & 3.0801 & 1.2454 \\
\hline NW354 & (6) & 10.1880 \\
\hline NW355 & 1.7960 & 8.8648 \\
\hline NW356 & 1.8482 & 7.2901 \\
\hline NW361 & 1.8352 & .2532 \\
\hline NW362 & 1. 1444 & 7.3800 \\
\hline NW369 & 1.4611 & 17.2351 \\
\hline NW371 & 1.5622 & 9.2978 \\
\hline NW372 & 0.5166 & 0.9779 \\
\hline NW381 & 1.9398 & 22.3772 \\
\hline NW382 & 1.8361 & 11.8555 \\
\hline NW383 & 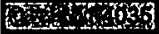 & 12.5365 \\
\hline NW384 & 1.7576 & 8.8480 \\
\hline NW385 & 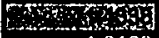 & 1.3262 \\
\hline NW390 & 1.8180 & 8.6713 \\
\hline
\end{tabular}

- Dark shaded areas imply that the respective coefficients are significant at 0.05 level and light ones at 0.10 level.

The last column of Table 8.5 signifies that in 24 sectors of Turkish manufacturing industry the imitation of the rate of growth of wage changes is strict. On the other hand, for 4 sectors, this takes place weakly. Only one sector does not follow the wage leading industries in either form. This sector is 372 (Non-ferrous Metal Basic Industries).

In conclusion, wage leadership model achieves an extraordinarily good performance for the explanation of wage determination process in the Turkish manufacturing industry. The results show the existence of wage leading and following behavior in Turkish manufacturing industry beyond doubt. More importantly, this wage-following behavior is likely to occur in the strict form. 


\subsection{Sources of Wage Leadership}

The next question is what determines or causes wage-following behavior. As in the case of the Dutch manufacturing industry, two possible sources account for the existence of this behavior, namely the extent of unionization and the product market structure. First, union channels and previously explained concerns of unions may cause the existence of the wage-leading following behavior. In order to analyze this relation, equation 6.30 is imposed on equation 8.5 , and the resulting equation is

$$
\begin{aligned}
\dot{W}_{i t} & =\beta_{0}+\beta_{1, i} \dot{v} a_{i t}+\beta_{2, i} \dot{w}_{a, t}+\beta_{3, i} \dot{w}_{i, t-1}+\beta_{4, i} \dot{m} w_{t}+\beta_{5, i} \dot{P}_{t}^{e} \\
& +\beta_{6, i} U^{-1} t-1+\alpha_{0, i} \dot{W}_{L, t-1}+\alpha_{1, i} U R_{i} \dot{W}_{L, t-1}+\beta_{7, i} R I C_{i, t}+\varepsilon_{t}
\end{aligned}
$$

$U R_{i} \Rightarrow$ Unionization rate in industry $i$.

The estimation results are presented in Table 8.6.

In 17 sectors, unionization variable has significant coefficients that is in the transmission of wage changes, unions have a serious impact for these 17 sectors.

Another channel of transmission of wage changes from wage leading to following sectors may be the product market structure as explained previously. In order to test this hypothesis, the wage leadership model is reestimated by imposing equation 6.33 on 8.5 . The resulting equation is

$$
\begin{aligned}
\dot{W}_{i t} & =\beta_{0}+\beta_{1, i} \dot{v} a_{i t}+\beta_{2, i} \dot{w}_{a, t}+\beta_{3, i} \dot{w}_{i, t-1}+\beta_{4, i} \dot{m} w_{t}+\beta_{5, i} \dot{P}_{t}^{e} \\
& +\beta_{6, i} U^{-1}{ }_{t-1}+\theta_{0, i} \dot{W}_{L, t-1}+\theta_{1, i} C R 4_{i} \dot{W}_{L, t-1}+\beta_{7, i} R I C_{i,}+\varepsilon_{t}
\end{aligned}
$$

$C R 4_{i} \Rightarrow$ four-firm concentration ratio in industry $i$.

The results of this estimation are presented in Table 8.7.

This channel of transmission of wages from one sector to another gives better results as compared to the unionization variable. In 22 sectors, the coefficients of concentration variable are found to be significant. Therefore, product market structure has an enormous effect in the transmission of wages.

\subsection{Concluding Remarks}

Table 8.8 summarizes the effects of both unionization and concentration in the growth rate of money wages in Turkish manufacturing industry. Only in 5 sectors unions arc found to be the transmission channel of wage changes from one sector to another. 


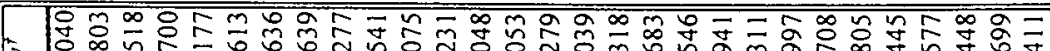
z

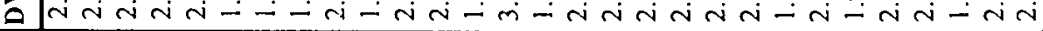

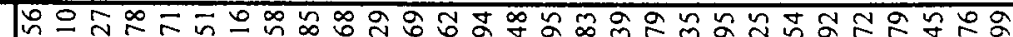

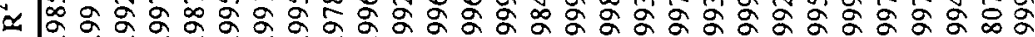

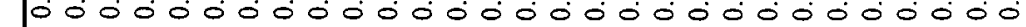
苛 U $\alpha=0$ ó

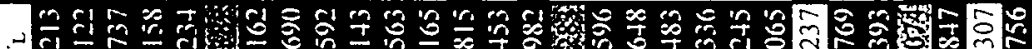

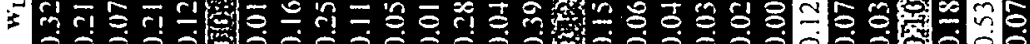
o

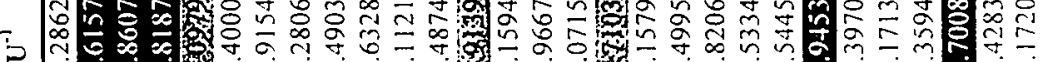

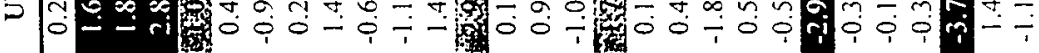

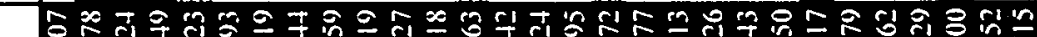

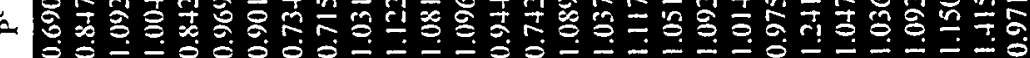

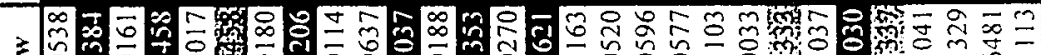

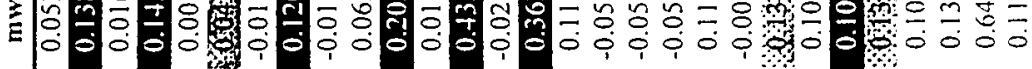

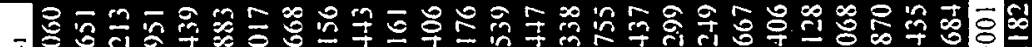
j - -

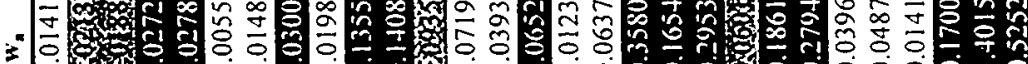

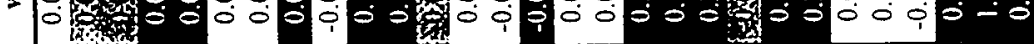
๘ $>\mid \frac{1}{0}$ i

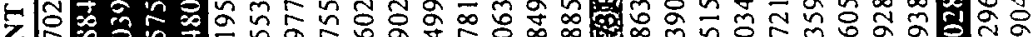
萑售

Z

$\ddot{x}$

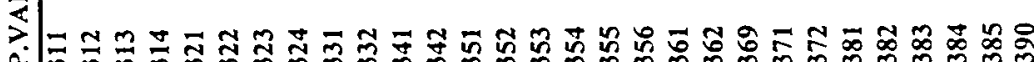

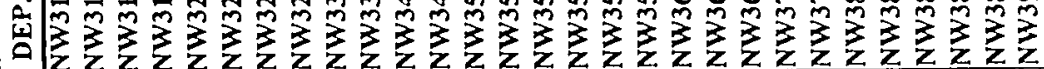


Moreover, in 10 sectors product market structure is a significant factor in this transmission of wage changes. Finally, for 12 sectors, both unions and product market structure determine the transmission of wage changes.

Table 8.8: Combined Effects of Unionization and Concentration in Turkey

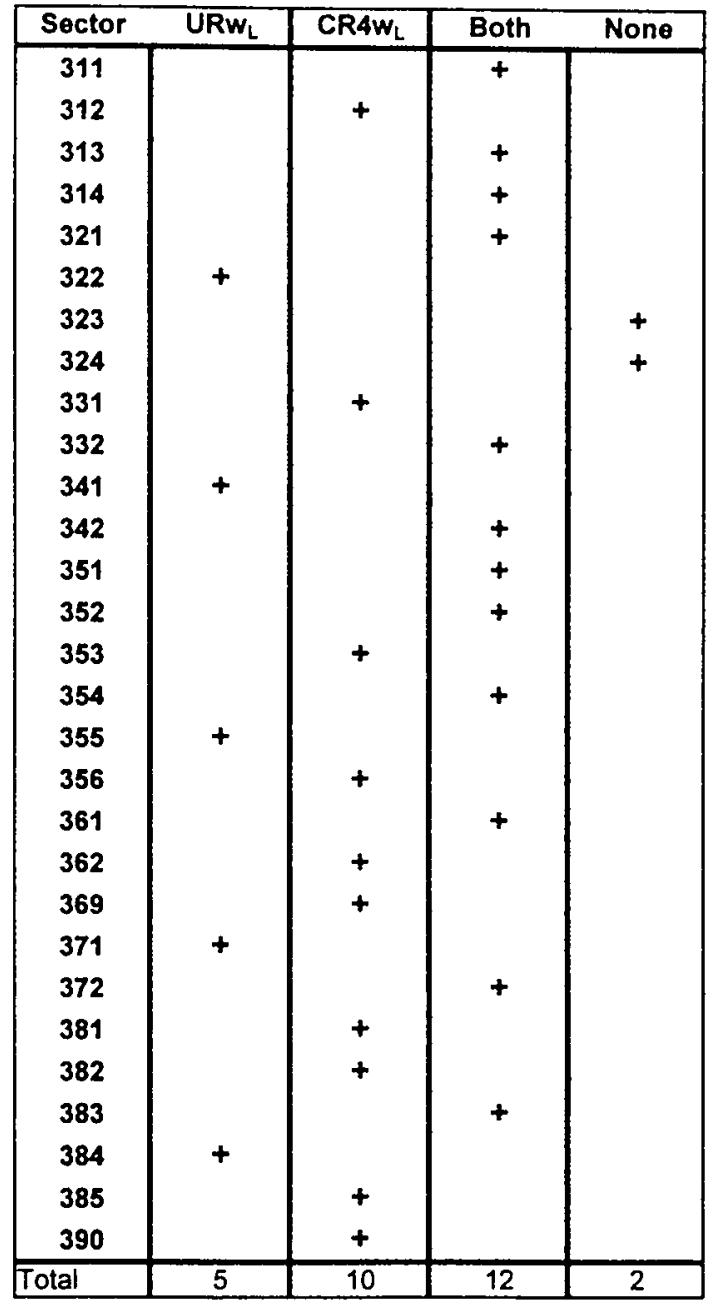

However, for 2 sectors, sectors 323 (Manufacture of leather, products of leather, leather substitutes, and fur) and 324 (Manufacture of footwear), none of these sources has any significant impact on the transmission process. However, these sectors have weak following and leading properties as can be observed in Table 8.2. 
Sector 324 has no following industry and only one leading industry. Sector 323 has 2 following and 1 leading industry. Therefore, the results of Table 8.8 are not very surprising indeed.

In sum, the wage leadership model has sufficient power to explain the growth of money wages in Turkish manufacturing industry. Although the bargaining model explains the growth of money wages well to some extent, there is substantial evidence for the wage leading and following behavior in Turkish manufacturing industry as can be seen in Table 8.4. Moreover, the imitation of wage changes is in the strict form, in other words most of the sectors precisely follow the wage changes in the leading sectors. Finally, in 27 out of 29 sectors of the Turkish manufacturing industry, unionization and/or product market structure may be held responsible for the transmission of wage changes.

In our previous study (Erdil:1997), which is the first study on testing wage spillovers in Turkish manufacturing industry, the wage leading sectors are found to be completely different. There are two main reasons of such a difference: First, Erdil (1997) finds wage leaders for public and private sectors separately. Second, it employs absolutely different methodology to determine wage leaders. ${ }^{55}$ The most important similarity between Erdil (1997) and this study lies in the fact that both studies find concrete evidence for the existence of wage imitation behavior in Turkish manufacturing industry.

ss Erdil (1997) employs the principal component factor analysis with quartimax rotation to determine the wage leaders in Turkish manufacturing industry which is later seemed to have less reliable properties as compared to methodology of this study. 


\section{APPENDIX 8: Turkish Data}

The Turkish data covers the period 1970-1994. In order to reach to real variables, the price indices with base year of 1968 are used. The data sources and the description of the data are as follows:

- Wage Data: Both nominal and real wages are average hourly wages paid. It is calculated by using the gross earnings that include all payments in the form of wages and salaries and per diems gross of income tax, social security and pension contributions and the like payable by the employer and it also includes overtime payments, bonuses, indemnities, and payments in kind (SIS,1988:VII). The data is obtained from Yillık Imalat Sanayi İstatistikleri (Annual Manufacturing Industry Statistics) of Devlet İstatistik Enstitüsü (State Institute of Statistics-SIS). The geographical coverage of the survey is the whole country. The statistics used cover all establishments in the public sector and establishments with 25 or more persons engaged in the private sector. However, it covers the private sector establishments with 10 or more persons engaged before 1983. Data are collected on the total number of hours worked and days worked by operatives in the year. Hours worked include hours actually worked during normal periods of work, overtime hours, and hours paid for but not worked, for time spent on vacation, holiday, casual or sick leave. The reference period of this data is the months of February, May, August, and November of each year.

- Value Added (va): It is also obtained from the Annual Manufacturing Industry Statistics of SIS. It is obtained by subtracting the value of input from output. The value of output is calculated by subtracting the beginning of the year stock of finished and semi-finished goods from the total of receipts from sales and services rendered to others, receipts from sales of transfers of electricity plus the end of year stock of finished and semi-finished goods and the production value of fixed assets produced by the establishments staff for own use (SIS,1988:IX). On the other hand, the value of input is calculated by subtracting the value of the end of year stock from the total value of goods and services purchased or transferred, electricity purchased and the beginning of year stock. The value added per worker is calculated and deflated by the sectoral producers' price indices (excluding Value Added Tax-VAT) whose base year is 1981 that are obtained from SIS. The 
employment figures covers the workers in the establishment whatever their title who were paid wages and salaries and employees who were temporarily absent on the day of survey because of illness, annual leave, or strikes etc. were also included. Unpaid family workers, owners, and partners are excluded.

- Minimum Wage ( $\mathrm{mw}$ ): It is the monthly minimum wage paid and obtained from Sosyal Sigortalar Kurumu (Social Insurance Institution-SII). If there is a change in the minimum wage paid during the years, the simple average of these values are used.

- Expected Rate of Growth in the Price Level $\left(P^{e}\right)$ : The expected rate of growth in consumer price index (CPI) is used. Price changes are assumed to influence workers in all sectors equally. It is the simple average of past, present, and future CPI. The data on CPI whose base year is 1968 that includes the VAT is obtained from SIS.

- Unemployment Rate $(U)$ : It is the rate of unemployed which comprises all persons at 12 years old and above but seeking to total labor force. Total labor force comprises all persons employed and unemployed. The persons employed consists of all persons 12 years of age and over working at least one day during the last week before the census to earn income or payment in kind; if they have not worked yet, their job attachments are continuing. The data after October 1988 is obtained from Hanehalkı İşücü Anketi (Household Labor Force Survey-HLFS) which is published semi-annually in the month of October and April. Before 1988, the data given by Bulutay (1992) is used.

- International Trade Data(Exports and Imports): This data is obtained from Dış Ticaret Müsteşarlığı (Undersecretary of Foreign Trade-UFT) which contains flows by ISIC, Revision 2 category (UFT, 1994). The data have been transformed from the Standard International Trade Classification (SITC).

- Concentration Ratio (CR4): It is the sectoral concentration ratios in terms of four largest firms' share of employment. Since the data is not available for the period 1970-1989, it is reproduced by using Bain's method of plant size and concentration (1966:27-30).

- Unionization Rate (UR): Union coverage in some sector is defined as the number of employees who are members of a trade union divided by the total number of employees in that sector. The data is obtained from Calışma ve Sosyal Güven! 
Bakanlığı (Ministry of Labor and Social Security-MLSS) (MLSS, 1970-1994 and MLSS, 1984-1997). All unions are enforced to declare the number of members to the Ministry by law twice a year, January and July. The average of these value is computed and used in the study. The main problem of this data is related with the classification. The Ministry uses a different industry classification other than ISIC. Therefore, we should convert it to ISIC. The MLSS data is transformed to ISIC classification as in the following way:

\section{MLSS Classification}

Food Industry

Textile Industry

Leather Industry

Wood Industry

Paper Industry

Printing and Publishing Industry

Petroleum, Chemistry, and Rubber Industry

Cement, Pottery, and Glass Industry

Metal Industry

\section{SIS Classification}

$311,312,313,314$

321,322

323,324

331,332

341

342

$351,352,353,354,355,356$

$361,362,369$

$371,372,381,382,383,384,385,390$

Another problem that exerts a serious limitation on the reliability of data is related with the laws in the pre-1980 period. In the pre-1980 period, a worker may become a member of more than one trade union, thus in some sectors we end up with unionization rates greater than one. In addition to this, we also have the problem of overreporting by the trade unions. All these problems tremendously affect the reliability of unionization data. Therefore, the results obtained by using this data should be examined cautiously by paying attention to these problems. 


\section{AN OVERVIEW ON THE POLICY IMPLICATIONS OF THE WAGE LEADERSHIP HYPOTHESIS}

\subsection{Introduction}

The findings of the previous chapters bring about a practically important question, "What kind of policies should be designed if the wage leadership model is relevant for a particular labor market and how?". To begin with, the meaning of the wage leadership should be recited. There are some key industries in which wage bargains first take place. Moreover, these industries act as wage-setters for the rest of the industries. In other words, the wage change behavior of wage-leading industries is followed by others. Therefore, the first aspect of the policy relevance of the model is that if a government follows a policy of wage moderation or wage restraint it should try to affect the wage negotiations in the wage leading industries.

Another relevant aspect in this framework is the existence of corporate pay policies and centralized labor markets. It is often argued that smaller states generally prefer to rely on corporatist strategies to smooth the process of industrial adjustment (Katzenstein, 1985:22). This depends not only on domestic factors but also on the fragility of their positions in the world markets. Smaller countries may not utilize protectionist policies to insulate themselves from changes in the world markets since they are strongly dependent on international trade. According to Katzenstein (1985:30), they must specialize in internal coordination amongst unions, employers, and state. In this framework, corporatism gives the possibility to harness social forces and to facilitate flexible response but not to constitute an obstacle on the burden of adjustment. In order to reach this end, the state tries to create an ideology of partnership at the national level; a relatively centralized system of interest groups; and both voluntary and informal coordination of conflicting objectives through continuing bargaining between interest groups, state bureaucracy, and political parties (Katzenstein,1985:32). These are the main .characteristics of Dutch industrial relations in the 1940s through 1950s, and in the last two decades. For Turkey, these 
characteristics are valid after the independence war of 1923 until 1950, and after the late 1960 s until today. ${ }^{56}$

Since the analysis of corporatism is not one of the major concerns of this chapter we will not aim neither to describe a policy modeling under corporatism and centralization nor an analysis of labor markets under these constraints. However, it is worth to present a discussion on the relevance of our findings with the issues of corporatism and centralization in the Dutch and Turkish labor markets.

\subsection{The Netherlands: All for One, One for All?}

It is often claimed that wage structure in the Netherlands is weakly responsive to labor market conditions because of the high degree of institutionalization of the wage setting process and welfare programs (Hartog, et.al.,1993). First, according to our findings from Table 7.4, the wage leadership variable is more relevant in the Netherlands when compared with the market variables in the manufacturing wage determination process. This means that there is a strong evidence for the existence of a wage leadership behavior in the Dutch labor market. Second, the results of different studies presenting the rank orderings of degree of centralization and corporatism given in Table 9.1 and 9.2 present an evidence for the relevancy of these concepts for the Netherlands.

Before going into detail, it should be noted that the concept of corporatism has a wider scope than the concept of centralization of industrial relations systems. It is possible to claim that corporatism includes centralization but cannot be reduced to the latter.

In Tables 9.1 and 9.2, the greatest differences are observed amongst the relative positions of Japan, Switzerland, Germany, and finally the Netherlands. These countries have a higher rank in the area of corporatism but are in an intermediate

\footnotetext{
s6 For Turkey, Bianchi (1984:139-46) puts forward four phases of development; incipent pluralism (1908-1924), limited state corporatism (1925-1946), debilitating pluralism (19461960), and emerging societal corporatism (1960-1980). It is possible to add a final phase as deficient societal corporatism (1981-present). The counterpart of these phases in the Dutch case may be listed as state corporatism (1946-1964), pluralism (1964-1981), societal corporatism (1981-present).
} 
position in terms of centralization. Therefore, the Netherlands is following strictly corporatist policies and/but has centralized institutions in some extent. Table 9.1: Rank Orderings of Countries According to Their Degree of
Centralization

\begin{tabular}{|lllllll|}
\hline Tarantelli & Schmitter & Cameron\&Sachs Calmfors\&Driffil & Calmfors & Blyth & Dell'Aringa \\
\hline Austria & Austria & Sweden & Austria & Austria & Austria & Austria \\
Japan & Norway & Norway & Germany & Norway & Norway & Norway \\
Germany & Sweden & Austria & Netherlands & Sweden & Sweden & Sweden \\
Denmark & Denmark & Belgium & Norway & Denmark & Denmark & Denmark \\
Finland & Finland & Finland & Sweden & Finland & Finland & Finland \\
Norway & Netherlands Denmark & Switzerland & Germany & New Zealand Germany \\
Sweden & Belgium & Netherlands & Denmark & Netherlands & Australia & Netherlands \\
Netherlands & Germany & Germany & Finland & Belgium & Germany & Belgium \\
Belgium & Switzerland & UK & Belgium & New Zealand Belgium & Switzerland \\
France & USA & Australia & Japan & Australia & Netherlands & Australia \\
Australia & Canada & Switzerland & New Zealand & France & Japan & Japan \\
Italy & France & Italy & UK & UK & France & France \\
UK & UK & Canada & France & Italy & UK & UK \\
Canada & Italy & USA & Italy & Japan & Italy & Italy \\
USA & & France & Australia & Switzerland & USA & Canada \\
& & Japan & Canada & USA & Canada & USA \\
\hline
\end{tabular}

Source: Dell'Aringa (1992)

Table 9.2: Rank Orderings of Countries According to Their Degree of Corporatism

\begin{tabular}{|llllll|}
\hline Tarantelli & Schmitter & Cameron & Bruno\&Sachs & Lehner & Dell'Aringa \\
\hline Austria & Austria & Sweden & Austria & Japan & Japan \\
Germany & Norway & Norway & Germany & Switzerland & Switzerland \\
Japan & Sweden & Austria & Netherlands & Austria & Austria \\
Sweden & Finland & Belgium & Norway & Sweden & Norway \\
Norway & Denmark & Finland & Sweden & Norway & Sweden \\
Denmark & Netherlands & Denmark & Switzerland & Netherlands & Denmark \\
Australia & Belgium & Netherlands & Denmark & Belgium & Germany \\
Netherlands & Germany & Germany & Finland & Germany & Finland \\
Finland & Canada & UK & Belgium & Denmark & Netherlands \\
Belgium & France & Switzerland & Japan & Finland & Belgium \\
Canada & UK & Australia & New Zealand & Australia & Australia \\
USA & Switzerland & Italy & UK & UK & UK \\
France & Italy & Canada & France & Italy & France \\
UK & & USA & Italy & USA & Italy \\
Switzerland & & France & Australia & Canada & USA \\
Italy & & Japan & Canada & France & Canada \\
& & & USA & & \\
\hline
\end{tabular}

Source: Dell'Aringa (1992) 
Some researchers may well think that the imitation of wage changes may be seen in less centralized economies where the following industries are supposed to imitate the wage changes occurring in key industries freely without any institutional or legal restrictions. However, such an approach seems to be incomplete, since imitation is not automatic. The state in a corporatist and centralized regime often targets key industries as arenas of the wage policies if it is aware of the fact that wage-leading following behavior exists. There may be political pressures, or in the extreme case legal pressures, throughout the bargaining process in the key industries. If the state is successful in this process, the story goes on with the propaganda for consensus. This created or "sham" consensus accelerates the wage adjustment process of other industries together with the wage leading-following behavior. If we evaluate all the findings of our study on wage inflation and other studies on corporatism and centralization, it is possible to explain the success of Dutch policy of wage moderation. In fact, the policy of wage restraint does not begin with a consensus, but produced a consensus and it is also encouraged by union leaders in some form to start an unrequited exchange of wage restraint for jobs (Visser and Hemerijck, 1997:109). The success of the policy of wage moderation brings redistribution of work through a reduction in labor-time, the growth of part-time jobs, the increase in female labor force participation, the replacement of older workers by younger. These changes show its effects on the unemployment rates; the unemployment rate is halved in the last decade and is now almost half the current level in EU. Most of the newly created jobs are part-time in nature and this can be considered as the second-best outcome: the expansion of part-time work has helped to attenuate the social division between fully employed and fully unemployed people (ibid, 42). The Central Planing Bureau estimates that half of the job growth of the past fifteen years can be attributed to wage moderation policies (ibid, 113). The Dutch trade unions have decided to support these changes and showed a positive attitude towards part-time employment and flexibility although these will have negative effects on union organizing. In 1995, unions and employers signed the first proper collective agreements for temporary workers, introducing a right of continued employment pension insurance after 24 months of service (ibid, 44).

One of the most important factors underlying Dutch success is the policy of wage moderation. The existence of vicious circle of high labor costs, large budget deficit, low incentives for labor to participate, and low profits are seemed to be clear 
for all social partners. In 1982, wage moderation was agreed upon in exchange for a reduction in working hours (Groenewegen, 1998). Trade unions believed in a redistribution of employment through a reduction of working hours. The bargaining position of trade unions in demanding wage increases was damaged because of high rate of unemployment and the general belief that labor costs in the Netherlands were relatively high. As presented by Groenewegen (1998), the trade unions accepted a freeze of wages and a reduction in social security allowances in exchange for labour time reduction and reduction of the budget deficit. The employers associations agreed upon the labour time reduction and the introduction of more part time work in exchange for lower labour costs and a reduction of taxes. Government guaranteed to reduce the budget deficit, to restructure the social welfare system and to eliminate the institutional rigidities in labour, capital, and product markets. In a later stage the wage moderation was exchanged for a reduction in taxes and social premiums that stimulated internal demand. Such a reduction was not possible until government had reduced expenditures, which was starting in 1983 (Groenewegen, 1998). It is observed that the common and ultimate target was the decrease in unemployment.

According to the findings explored in section 7.5, the main transmission channel of wage changes is unions in the Netherlands. Therefore, the Dutch policy towards the creation of centralized union structure seems to be well established. Finally, it is possible to conclude that the Dutch corporatist policies in the labor market can be judged as successful with regards to both wage and employment.

\subsection{Turkey: From State Corporatism to Societal Corporatism?}

Before going into the details of the development of Turkish corporatist practices, it would be better to conceptualize state and societal corporatism. Schmitter (1974) suggests that the corporatization of interest representation is related to certain structural imperatives of capitalist development and distinguishes two types of corporatization; state corporatism and societal corporatism. Although both have some institutional similarities, they are the products of different political, social, and economic processes and serve as means for different interest representations. Schmitter (1974:107-108) states that

\footnotetext{
the origins of societal corporatism lie in the slow, almost imperceptible decay of advancid pluralism; the origins of state
} 
corporatism lie in the rapid, highly visible demise of nascent pluralism... Societal corporatism appears to be the concomitant, if not ineluctable component, of the post-liberal, advanced capitalist, organized democratic welfare state; state corporatism seems to be a defining element of, if not structural necessity for, the anti-liberal, delayed capitalist, authoritarian, neo-mercantilist state.

The ability of Turkish Republic to preserve its traditional role as the leading architect of associational representation signifies that there is a good deal of continuity between the efforts to promote societal corporatism and the previous experiments of authoritarian modernizers ${ }^{57}$ with state corporatism. There has been an important long-lasting transformation in Turkish corporatist policy from previous authoritarian techniques to the less coercive techniques of the period just before 1980 . The military coup d'etat of 1980 has broken this transformation but after the mid 1980 s the transformation has begun again. However, it is not easy to clarify the differences amongst these periods whether they reflect radically different historical processes or diametrically opposite relations of power and influence. ${ }^{58}$ In this transition period, corporatist arrangements cannot be considered as a more or less spontaneous response to prior changes in civil society. The emergence of societal corporatism is not unquestionably a result of deliberate public policy, contrived and controlled by pre-existing authority groups (Schmitter, 1977:8-10).

The emergence of societal corporatism in Turkey seems to be the result of the endeavors of governments to create a series of representational cartels in the major sectors and to draw them into a centralized, state-directed bargaining process that would facilitate planned economic development. The state has exerted its main power to create this pattern of corporatist bargaining, to screen the group representatives that are invited to participate in negotiations, and to structure most of the agenda. While governments have faced some difficulties to control and to consolidate the new system of societal corporatism, their struggles have been subordinated by their ability to rely upon and to expand some of the same associational structures and legal

57 It is possible to call the founders of modern Republic of Turkey and politicians until 1950 as "authoritarian modemizers".

${ }^{58}$ For a detailed discussion of the transformations involved in Turkey for pre-1980 period, see Bianchi (1984) and Schmitter (1977). 
provisions inherited from previous experiments of state corporatism. When this inheritance seemed to be insufficient for voluntary cooperation, more restrictive associational legislation, unkept promises of greater material assistance from the state and frequent resort to coercion were likely to be utilized. During 1980s and early 1990 s, intensive use of all of these measures can be observed.

When Turkish societal corporatism is compared with Western European experiences, it seemed to be unusual since it emerged in an environment where advanced capitalist development and strong pluralist traditions were lacking (Cizre,1984). Turkey's relative underdevelopment and institutional weaknesses may not be considered as an obstacle for the state to create a more centralized system of corporatist bargaining. This framework encouraged a bargaining process in which the state retained an unusually high degree of-independence from group demands and in which the representatives of different economic sectors rarely arrived at mutually satisfactory agreements through unmediated negotiation (Bianchi,1984:378). From 1970s until 1990s, group bargainers focused their efforts on trying to maneuver one another into making most of the sacrifices that were necessary for greater capital accumulation instead of trying to negotiate a more equitable division of the country's economic surplus since the need for restructuring Turkey's weak and externally dependent industry is often stressed in the bargaining processes.

In the view of the often discouraging experiences that Turkish unionists have had with pluralist strategies of organization, it is not surprising that the leaders of the largest union confederation, Türk-İs, perceived the introduction of corporatist measures as an opportunity to overcome their traditional isolation. The artificial attempt to create a representational cartel for organized labor made an important contribution to restructuring the labor movement and changing its political role yet not in the manner that was intended by the state. The corporatist labor measures caused the acceleration of demonstrations of workers in 1970s. There was an increasing demand for political unionism and even Türk-İs leaders were forced to follow a more militant and politically activist policies in order to compete with their rivals of the left.

As the policies of development seemed to defer a broader distribution of the benefits of economic growth until the end of the century, public policy towards associations became a key element in the attempt to reconcile rapid economic development with democracy and to aveid a return to authoritarian rule. Policy 
towards associations sought to encourage cooperative interest group leaders in the major economic sectors to share the responsibility for implementing development programs and to voluntarily moderate demands for political participation and economic redistribution. The principal mean through which governments can attempt to achieve these objectives is the corporatization of associational interest representation that can be promoted in three major forms: First, the state can attempt to foster collaborative class relationships and to coordinate nation-wide collective bargaining through vertically structured quasi-monopolistic associations in the key economic sectors; second, it can use the legally provided right for state to intervene to industrial conflicts and settle them in accordance with the premises of corporatist strategies; third, it can put important restrictions on the political activities of associations in order to inhibit uncooperative and dissatisfied interest group leaders from exploiting noncorporatist channels of representation and forming alliances with opposition parties.

According to the findings of chapter 8 , it can be argued that the state is successful to realize corporatist objectives, since in only one sector (Non-Ferrous Metal Basic Industries), the wage leadership hypothesis is irrelevant. Moreover, in 27 out of 29 sectors, unionization and/or product market structure are the main transmission channels of wage changes. The state has reached its objective to create a centralized union and bargaining structure. The representational monopolies are legislatively established rather than independently conquered and leaders often seek the elimination of their rivals through state harassment rather than through organizational competition. More importantly, the state is also successful in creating a rather monopolistic product market structure by the intended policies.

It seems reasonable to conclude that the weaknesses of Turkish capitalism combined with restricted and fragmented Turkish experience with associational pluralism have resulted in a more or less clear-cut distinction between the earlier form of state corporatism and the societal corporatism in contrast to what has been experienced in Europe and Latin America (Schmitter, 1981:100-105). The corporatization in Turkey may not be considered as an example of pure societal corporatism yet it is rather an unusual and unstable mixture of both state and societal corporatism. It is observed that the initiative for the corporatization of interest representation has mainly come from the state's attempts to co-opt reliable clients that are willing to share responsibility for policy implementation, and not from a confident 
and aggressive set of interest group leaders seeking to translate preexisting organizational strength into a greater role in policy formation. According to Bianchi (1984:145), the major advocates of corporatism in Turkey regard it as a policy measure to incorporate the associations of subordinate classes, especially trade unions, within the framework of liberal democracy in order to strengthen the unstable bourgeoisie-dominant regime. However, Turkish corporatists do not argue that corporatization should be accompanied by the establishment of a welfare state as it was in Europe.

\subsection{Concluding Remarks}

Our study has validated one of the most common findings of other studies on the Dutch labor market; wage determination process is affected by institutional factors rather than market conditions. Similar findings can also be seen in the studies dealing with other European countries. The reasoning of these findings was based on the concept of welfare state in some studies. The critique of the welfare state is organized around its potential for creating labor market rigidities. It is often claimed that these rigidities impede flexible adjustment, block technological innovation, and hamper necessary economic and employment growth (Visser and Hemerijck,1997:178). However, the "Dutch Miracle" as termed by Visser and Hemerijck (1997) has falsified these failures of the welfare state. However, this does not mean that the Dutch labor market does not have any problems. It suffers from some significant problems such as structural unemployment and disadvantages for unskilled and nonnative workers as well (EUROSTAT:1997b). But what is more important is the success of Dutch policies in reducing unemployment to acceptable levels within a decade. Moreover, the extraordinary performance of Dutch labor market policies did not come out of the blue sky. Two factors among others are very important indeed; the corporatist tradition in the Netherlands, that also includes centralization in some extent, and the relevancy of the wage leadership hypothesis in the Dutch labor market. These two factors are the indispensable elements of the "Dutch Miracle".

With regards to the historical attitudes of successive ruling elite towards political representation, it may well be claimed that the Ottoman and Turkish political tradition tends to favor corporatism more in terms of granting to certain association: legal monopolies of representation and i. guaranteed access to decision making in 
return for privileges, than pluralism as commonly understood by the existence of autonomous private associations. In fact, the public policy in Turkey has fluctuated between pluralist and corporatist policies. In periods when the freedom of association has not been clearly repressed, private associations have represented the closest approximation to the pluralist paradigm but public associations were adhering more closely to corporatist paradigm. Moreover, the changing pattem of public policy especially with regards to trade unions from repression, pre-emptive co-optation, fragmentation, and corporatism is due to a concern to prevent and contain the class conflict that emerged in the type of socioeconomic, legal, and attitudinal context. In sum, it may be said that the attempts to create societal corporatism in Turkey have been mainly obstructed by the weakness of capitalist development and by the lack of traditional pluralism. The somewhat discriminatory effects of these polices in the labor market through wage determination may cause an increase in conflicts in industrial relations.

In conclusion, the most differentiated characteristic of corporatist experiences in two countries is that institutions determine policy until politics determine institutions in the Netherlands but the causality runs in the reverse direction in the Turkish case. For the Dutch labor market, there are numerous studies that have discussed the impacts of corporatist policies. For Turkish labor market, however, there is only one study that indirectly analyzes the consequences of corporatist pay polices. In fact, the detailed analysis of corporatism is far beyond the scope of our study. We have tried to summarize the results of some studies and incorporated our results within this framework. What our study suggests for further research in the context of wage determination process is the urgent need for a political-economic analysis of corporatism, especially for the Turkish labor market. 


\section{SUMMARY AND CONCLUSIONS}

This study deals with the analysis of the wage determination process both on theoretical and empirical grounds. The first part concentrates on a detailed analysis of the characteristics of the Dutch and the Turkish labor markets. The main points of analysis are an historical account of the policies in the labor markets, the main features of the labor markets including labor force and unemployment structure, employment and wages in manufacturing industries, institutions in the labor market, and the legal framework of industrial relations.

The postwar history of the Dutch labor market presents a move toward decentralization. The problems brought by the war necessitated the introduction of highly centralized policies. However, the guided wage-and employment policies ended in the second half of 1960s. Another distinguished characteristic of this story is the high degree of consensus among the workers, employers, and government. Nowadays, the policies are directed towards the reorganization of work and employment relations. New policies aim to increase the flexibility in the labor market in order to meet the changing conditions in the markets and to lower unemployment.

In terms of participation, we observe a gradual increase in the participation rates. Especially from the second half of 1980 s onwards the rate of increase speeds up. The main reasons of non-participation as surveyed in 1990 and 1996 are personal and family responsibilities, retirement, education, and disability. As a result of the policies toward flexibility and increasing unemployment, the share of part-time employment rises continuously. The increasing unemployment until the mid of the $1980 \mathrm{~s}$ is the most notable characteristics of the Dutch labor market. This increase may be attributed to the labor force growth and the restrictive macroeconomic policies. Moreover, almost half of the unemployed persons are long-term unemployed. However, the increasing trend in unemployment figures is reversed by the implementation of successful policies in the last decade.

The employment share of the manufacturing industry follows an uninterrupted fall in the 1980s and 1990s as it is in the case of other industrialized OECD countries. Not only the employment share of the manufacturing industry but also the total employment in the manufacturing industry decreases. Manufacture of wearing apparel and manufacture of footwear are determined as the low-wage industries. Manufacturc of products of petroleum and coal and petroleum refineries, on the other hand, are the 
high-wage industries. The wages become more and more dispersed in the Dutch manufacturing industry between 1970 and 1993. Finally, the real hourly wages follow an increasing tendency and they rise about 160 per cent during the same period.

As for the institutions in the Dutch labor market, the share of organized labor decreases and around 70 per cent of all workers is unorganized. This results in the weakening of the Dutch labor movement. In contrast to workers, employers are less organized and less inclined to act collectively. At the central level there are side by side organizations representing employers' associations and individual firms.

Legally, the effect of central government and other centrally organized institutions on the wage determination process declined gradually in time and the approach in the legal framework became more individualistic. However, there has been a tendency of increasing central influence since the mid 1990s.

Major political and economic transformations shaped labor market policies in Turkey. During passage from multi-party regime to planned economy phase and then to liberal phase, the governments followed different and somewhat conflicting strategies. In fact, in times of political chaos, it is difficult to argue that policy prescriptions and planned targets are properly implemented or that there is a realistic labor market policy. The major factor shaping the urban employment throughout the years is continuous migration from rural to urban areas. The migration of lowqualified and low-educated villagers to urban areas causes structural problems for the labor market. In the 1980s, the primary emphasis is on the policy realignment in both domestic factor markets and the foreign trade regime. These policies indirectly affect the labor market. For the second half of 1980 s, the government claimed that through such policy reforms it would be possible to employ relatively more labor-intensive technologies and specialize in activities in line with existing factor endowments. However, in the early 1990s, the structure of production was directed in accordance with the employment-creation target taking also into account productivity and efficiency considerations. In terms of the foreign trade regime, the creation of an exportable surplus and controlling the inflation requires domestic demand restraint for which wage restraint is used as a key factor. Wage restraint was also regarded as an important tool for attaining international competitiveness under an export-oriented strategy and wages were at the same time considered as an important cost item. However, it is not possible to defend the view that these policies were successful in the labor market in terms of employment creation: What happened was that 
underutilized capacity was reactivated instead of creating new capacities. It seems that factors on the supply side of the labor market will continue to shape the market in the near future. The size of new entrants into the labor force with increased concentration in urban areas indicates that employment creation will fall short of these pressures from the supply side.

The most distinguished characteristic of Turkish labor market is its segmented structure in terms of a three-tier segmentation composed of the agricultural, the urban informal, and the formal sector. As we regard the participation rates, what we observe in reality is the regular fall in the participation rates from 1970 to 1995: it falls from 64 per cent to 50 per cent. Another important point is that male participation rates are significantly higher than female participation rates. This means that women in Turkey are not as successful as men in the integration into the labor market and they prefer to stay at home as housewives. Being retired and being disabled are the main reasons for male non-participants. On the other hand, the unemployment rate fluctuates and reaches its peak at the end of 1970s. In the first half of 1990s, it seems to stabilize at around 8 per cent. However, some researchers insist that the official statistics are erroneous and that the real unemployment rate is higher than what is recorded. Moreover, unemployment in Turkey has a long-term characteristic.

Both the employment share and the level of employment in the manufacturing industry increase in the period of 1970-1994. The number of workers employed in the manufacturing industry rise by more than 100 per cent between 1970 and 1994. For the wage structure in Turkish manufacturing industry the low-wage industries are manufacture of furniture and fixtures, manufacture of wearing apparel, and manufacture of leather and products of leather. On the other hand, the high-wage industries are petroleum refineries, manufacture of products of petroleum and coal and manufacture of chemical products. Wage dispersion is relatively high in $1970 \mathrm{~s}$ then it decreases considerably in 1980s but it has again an increasing trend in $1990 \mathrm{~s}$. The real wages in Turkish manufacturing industry do not follow a stable path. There are major upswings and downswings in sub-periods. In the last years, there is a significant increase in real wages. When compared with the level in 1970, the increase in real wages is greater than 100 per cent.

Turkish trade union movement faced major legal and political barriers. Until 1947, to organize in unions was banned by law and later only unionism without having right to strike was permitted. With the Constitution of 1961 , union freedom, 
the right of collective bargaining, and the right to strike were guaranteed. In 1980, Turkish trade union movement was attacked by the military government and all trade union activities were suspended. The 1982 Constitution and new legislation are very restrictive for trade union activities. Union density rates fluctuate around 55 to 70 per cent from 1984 to 1997 and in the first half of 1997 it is around 66 per cent.

In Turkey, the employers organized later than employees. The employers' associations began to be influential after 1970. The most important gains of employers' associations were obtained in the first half of 1980 s and they played an effective role in the preparation of new legislation and almost all their requirements were legalized. Finally, both trade unions and employers' associations have a highly centralized organizational structure.

In legal terms, the rights of workers that were gradually gained from the Republican era to 1980 are blocked by the 1982 Constitution and existing legislation. They are very restrictive and more inclined to defend the employers' rights.

The last chapter of Part I, chapter 4, compares and contrasts the labor markets and industrial relations systems of the Netherlands and Turkey. Moreover, this chapter also discusses the relevancy of the wage leadership model in the framework of these countries. The Dutch economic system is based on values of stability and security. Actors involved in the process of the institutional changes are becoming as parts of the process and this makes them responsible for the implementation. In this setting, agents have a well-established role. Trade unions, employers and government realized that there are interrelated elements, namely wage moderation, a reduction of working time and a reduction of the government deficits and they should somewhat be coordinated in order to solve severe economic problems experienced at the beginning of the $1980 \mathrm{~s}$. The corporatist tradition helps to overcome the problems.

The industrial relations system in Turkey was not established on democratic grounds as in the case of the Netherlands. The dominant form is the state-directed bargaining and coercive institutions. In other words, the result is the state directed corporatism. Moreover, unlike the Netherlands, the industrial relations system was characterized by conflict at each and every stage rather than consensus. This situation enforces a bargaining process characterized by high state intervention indifferent to the demands of the actors. 
The figures on the labor markets of these two countries summarize the following points:

Netherlands

Increasing labor force participation

Increasing female participation

$1 / 3$ of working population is in part-time jobs

High unemployment cured by direct labor market policies

Concentration of unemployment in younger age groups

Ratio of long-term unemployed is $80 \%$

Widening of gap between unemployment and vacancies

Decline in employment share of manufacturing

Real hourly wages have a stable increasing trend in manufacturing

\author{
Turkey \\ Decreasing labor force participation \\ Decreasing male participation \\ $1 / 4$ of working population is in part-time jobs \\ High unemployment cured by general \\ macroeceonomic policies \\ Concentration of unemployment in younger \\ age groups \\ Ratio of long-term unemployed is $65 \%$ \\ Narrowing of gap between unemployment \\ and vacancies \\ Rise in employment share of manufacturing \\ Fluctuations in the level of real hourly wages \\ in manufacturing
}

In both countries, it is observed that some collective bargains in critical industries are treated as the anchors in setting macro annual wage targets since these bargains are followed by others and in turn determine the annual rate of wage inflation. This is the main motivation causing us to think about that wage imitation behavior may be relevant. In sum, most of the characteristics of the Dutch and Turkish labor markets are very differentiated but what is common in both countries is the significant experience of centralized wage determination process.

In the first chapter of Part II, Chapter 5, a brief analysis of orthodox theory of wage inflation are presented in the context of a conventional bargaining model and then a historical outlook to the development of a theory of wage inflation emphasising the relevance of institutional factors are discussed. The empirical literature reviewed in this chapter presents a substantial evidence for the relevance of institutional theories in labor markets. However, this does not mean the rejection of the orthodox theory entirely. These two theories are, in fact, complements in some sense. Since the institutionalist theory uses the basic premises of the orthodox theory of wage determination, it is not possible to claim that orthodox theory is irrelevant completely. The use of neoclassical postulates in institutionalist theory may be considered as its weakest point.

In chapter 6 , after an analysis of the properties of the bargaining models, two variants of bargaining models of wage inflation are formulated in the light of the models discussed in chapter 5. First, the general properties of bargaining models arc 
discussed. Second, a typical bargaining model of wage inflation is presented. Finally, the wage leadership formulation as a representative version of spillover models of wage inflation is derived. Moreover, our aim is not only to verify relevancy of the wage leadership model but also to search for the possible institutional factors behind this behavior. For this end, sectoral unionization rate and sectoral concentration ratio are offered as the possible sources. Tests for the effects of these variables will complete the analysis. This chapter provides the tools of analysis for the next chapter concerning the empirical application.

Part III explores the wage determination processes in the Dutch and Turkish manufacturing industries. For each country, first, a bargaining model then, as an extension of this model, the wage leadership model are estimated. The method of estimation in both cases is Seemingly Unrelated Regression (SUR) method. In the context of the wage leadership model, a method for choosing the wage leading sectors is also outlined. In chapter 7 , the simple bargaining model is found to be inadequate to explain the growth of money wages for the Dutch manufacturing industry. Surprisingly, value added and real wage variables are not significant for most of the sectors. Only measures of labor market tightness and opportunity cost of labor give significant results. Printing, Publishing and Allied Industries and Manufacture of Industrial Chemicals are found to be the wage-leading sectors for the Dutch Manufacturing Industry. All the test results show that the wage leadership model sufficiently explains the rate of growth of money wages in the Dutch Manufacturing Industry and the significance of variables that also exist in the first model improves with the introduction of wage leadership variable. Therefore, there is an important evidence in favor of the existence of the wage leading and following behavior in the Dutch Manufacturing Industry. We specify two candidates as a source of wage leading and following behavior, namely concentration and unionization. In two separate systems of regressions, the coefficients of unionization and concentration variables show that wage changes are transmitted by one of these channels for 17 sectors of the Dutch Manufacturing Industry. Tests for the type of leading-following behavior in the Dutch Manufacturing Indurstry imply that wage following behavior is in the form of strict imitation rather than the weak one. In conclusion, our model validates the assumptions of the wage leadership hypothesis for the Dutch Manufacturing Industry. Although there are differences in the determination of wages in a previous study by Graafland and Verbruggen (1993), we have found significant 
similarities between two studies especially related with the wage leaders in the manufacturing industry. The differences may be related with the coverage of data.

In chapter 8 , the same steps are repeated for the Turkish Manufacturing Industry. The bargaining model, to some extent, is more successful to explain the growth rate of money wages in the Turkish Manufacturing Industry when compared to the Dutch Manufacturing Industry. The only interesting result is insignificant coefficients on the productivity variable. Food Manufacturing and Petroleum Refineries are found to be the wage leading sectors. The wage leadership model works for the explanation of wage determination process in Turkish Manufacturing Industry since in 28 sectors wage leadership coefficients are found to be significant. Moreover, the wage-following behavior is in the strict form. Finally, only in 2 industries neither concentration nor unionization is found to be the wage transmission channel, but for the rest of 27 industries they sufficiently explain how wage changes are transmitted from one sector to another. To sum up, although the simple bargaining model explains the growth of money wages well to some extent, there is a firm evidence for the wage leading and following behavior in the Turkish Manufacturing Industry, and the wage leadership model is very powerful in explaining the growth of money wages in the Turkish Manufacturing Industry. Although in our previous study (Erdil:1997) the wage-leading sectors are found to be different, both studies find concrete evidence for the existence of wage imitation behavior in Turkish manufacturing industry.

Chapter 9 is devoted to the policy implications of findings in chapters 7 and 8 in the context of corporatism and centralization debate. There are traditionally shaped differences between the corporatist experiences of the Netherlands and Turkey. Furthermore, the degree of success of these corporatist polices through time differs between these two countries as well. Corporatist components in the labor market may explain the success of the Dutch wage moderation policy, extraordinary job creation and in turn significant decrease in unemployment. This success also helps us to understand the peaceful industrial relations in the Netherlands as compared to other European countries. However, this proposition is not valid for the Turkish case since the policies implemented by successive governments have been insufficient to consider the main dimensions of the labor market in which there exists important imbalances. The successive policies can also be treated as inconsistent, and they have sometimes caused uncertainties and created conflicts in industrial relations. 
As a study of wage inflation, this study performs various tests for both the bargaining and the wage leadership models for the Dutch and Turkish manufacturing industries. Although we find some evidence for the relevancy of the former model, this model alone is not sufficient to explain the dynamics of wage changes. The wage leadership model performs better for both countries and institutional channels of wage transmission are found to be effective in this transmission. However, the relevancy of these models may depend upon the subjective conditions of countries or the time period considered and the models may be enriched with the introduction of new variables. Still, we reach important and undeniable conclusions in favor of institutional mechanisms in the determination of wages for the Netherlands and Turkey. 


\section{REFERENCES}

Aarts, L. and Jong P.R. de, 1992, Economic Aspects of Disability Behavior, Amsterdam: North Holland.

Addison, J. and Burton, J., 1977, "The Institutionalist Analysis of Wage Inflation: A Critical Appraisal", Research in Labor Economics, 1, 333-76.

Addison, J. and Burton, J., 1978, "Wage Adjustment Process: A Synthetic Treatment", British Journal of Industrial Relations, 16, 208-23.

Addison, J. And Burton, J., 1979, "The Identification of Market and Spillover Forces in Wage Inflation:A Cautionary Note", Applied Economics, 11, 95-104.

Addison, J. and Burton, J., 1984, "The Sociopolitical Analysis of Inflation", Weltwirtschaftliches Archiv, 120, 90-120.

Addison, J. and Siebert, W.S., 1979, The Market for Labor: An Analytical Treatment, Santa Monica:Goodyear Publishing Company, Inc.

Addison, J.T., 1975, "On the Interpretation of Labor Market Earnings Dispersion", International Journal of Social Economics, 2, 43-51.

Agarwala, R., Drinkwater, J., Khosla, S.D., and McMenomy, J.E., 1972, “A Neoclassical Approach to Determination of Prices and Wages", Economica, $39,250-63$.

Ahlen, K., 1989, "Swedish Collective Bargaining under Pressure: Inter-Union Rivalry and Incomes Policy", British Journal of Industrial Relations, 27, 330-46.

Ahrne, G., 1988, Class and Social Organization in Finland, Sweden and Norway, Uppsala:Uppsala University Press.

Albeda, W., 1989, "Labor Relations and Neo-Corporatist Decision-making", in Theories and Concepts in Comparative Industrial Relations, eds.J. Barbash and K. Barbash, New York: Columbia University Press.

Alestalo, M. and Kuhnle, S., 1984, "The Scandinavian Route. Economic, Social, and Political Developments in Denmark, Finland, Norway, and Sweden", Research Reports for Comparative Sociology, No:31, University of Helsinki. Andersen, T. M. and Risager, O., 1991, "A Wage Bargaining Model for Denmark", Applied Economics, 23, 567-78.

Anderson, C.H., 1972, "Wage Spillover Mechanisms: A U.S.- Canadian Analysis", Industrial Relations, 11, 172-82. . 
Andersson, J. O., 1993, "Economic Integration, the Nordic Models and

Unemployment, in European Economic Integration: A Nordic Perspective, eds. J. Fagerberg and L. Lundberg, Aldershot: Avebury.

Andrews, M. and Nickell, S., 1983, "Unions, Real Wages and Employment in Britain 1951-79", Oxford Economic Papers, 183-206.

Arestis, P. and Mariscal, B.F., 1995, "Wage Determination in the U.K.", Applied Economics, 27, 523-28.

Artstein, Y. And Sussman, Z., 1992, "Wage Dynamics in Israel: Market Forces and Spillover Effects", Applied Economics, 24, 969-79.

Ashenfelter,O.C., Johnson,G.E., 1969, "Bargaining Theory, Trade Unions, and Industrial Strike Activity", American Econimc Review, 59, 35-49.

Ashenfelter,O.C., Johnson,G.E., and Pencavel,J.H., 1972, "Trade Unions and the Rate of Change of Money Wages in United States Manufacturing Industry", Review of Economic Studies, 39, 27.-54.

Bain, J.S., 1966, International Differences in Industrial Structure: Eight Nations in 1950s, New Haven:Yale University Press.

Bakels, H. and Opheikens, L., 1982, Schets van het Netherlands Arbeidsrecht, Deventer.

Barrett, B., 1975, Industrial Relations and the Wider Society, London:Collier Macmillan.

Baxter, J.L., 1973, "Inflation in the Context of Relative Deprivation and Social Justice", Scottish Journal of Political Economy, 20, 262-82.

Behman, S., 1964, "Labor Mobility, Increasing Labor Demand, and Money Wage Rates Increases in United States Manufacturing", Review of Economic Studies, 31, 253-66.

Behrend, H., 1960, "Some Aspects of Company Wage Policy", Journal of Industrial Economics, 8, 221-34.

Bemmels, B.G. and Zaidi, M.A., 1990, "Wage Leadership in Canadian Industry", Applied Economics, 22, 553-67.

Berg, A. van den and Groot W., 1992, "Union Membership in the Netherlands: A Cross-Sectional Analysis", Empirical Economics, 17, 537-64.

Berg, J.E. van den, 1995, Trade Union Growth and Decline in the Netherlands, Amsterdam: Thesis Publishers. 
Bhargava, A., Franzini, L. and Narendranathan, 1982, "Serial Correlation and the Fixed Effects Model", Review of Economic Studies, 49, 533-49.

Bianchi, R., 1984, Interest Groups and Political Development in Turkey, Princeton:Princeton University Press.

Blanpain, R. and Engels, C., 1993, Comparative Labor Law and Industrial Relations in Industrialized Market Economies, Deventer: Kluwer Law International.

Booth, A.L., 1995, The Economics of the Trade Union, New York:Cambridge University Press

Boratav, K., 1989, Türkiye Iktisat Tarihi 1908-1985, Istanbul:Gerçek Yayınevi.

Borjas, G.J., 1979, "Job Satisfaction, Wages, an Unions", The Journal of Human Resources, 14, 21-40.

Brechling, F., 1973, "Wage Inflation and Structure of Regional Unemployment", Journal of Money, Credit, and Banking, 5, 355-84.

Brown, E.H., 1962, “Wage Drift”, Economica, 29, 339-56.

Brown, W. and Sisson, K., 1975, "The Use of Comparisoms in Workplace Wage Determination", British Journal of Industrial Relations, 13, 23-53.

Brunn, N., Flodgren, B., Halvorsen, M., Hydén, H., and Nielsen, R., 1992, The Nordic Labor Relations Model: Labor Law and Trade Unions in the Nordic Countries- Today and Tomorrow; Aldershot: Darmouth Publishing.

Brunn, N., 1994, "The Transformation of Nordic Industrial Relations", in Transformation of European Industrial Relations: Consequences of Integration and Disintegration, Helsinki: IIRA $4^{\text {th }}$ European Regional Congress, Vol. I, 15-43.

Bruno, M. And Sachs, J., 1985, The Economics of Worldwide Stagflation, Massachusetts:Harvard University Press.

Bulutay, T., 1992, “A General Framework for Unemployment in Turkey”, in SIS, Seminar on Employment, Unemployment, and Wages in Turkey, 15-16 October 1992, Ankara:mimeo.

Bulutay, T., 1995, Employment, Unemployment, and Wages in Turkey, Ankara: ILO and SIS.

Calmfors, L. and Driffil J., 1988, "Bargaining Structure, Corporatism and Macroeconomic Performance", Economic Policy, A European Forum, 6, 13 47. 
Calmfors, L., 1993a, "Comment on Moene, Wallerstein and Hoel", in Trade Union Behavior, Pay Bargaining and Economic Performance, eds. R. Flanagan, K. O. Moene, and M. Wallerstein, Oxford: Oxford University Press.

Calmfors, L., 1993b, "Lessons from the Macroeconomic Experience of Sweden, European Journal of Political Economy, 9, 25-72.

Cameron, D.R., 1984, "Social Democracy, Corporatism, Labor Quiescence and the Representation of Economic Interest in Advanced Capitalist Society", in Order and Conflict in Contemporary Capitalism, ed. J.H. Goldthorpe, Oxford: Clarendon Press.

Campbell, J.,1992, European Labor Unions, Westport:Greenwood Press.

Card, D., 1990, "Strikes and Wages: A Test of an Asymmetric Information Model", Quarterly Journal of Economics, 105, 625-59.

CBS, 1993, Statistical Bedrijfs Indeling, Heerlen:CBS.

Cizre, Ü., 1984, “Interest Groups and Political Development in Turkey by R.Bianchi”, A Book Review, METU Studies in Development, 11, 3\&4, 399-404.

Copeland, L.S., 1977, "Wage-Inflation, Productivity, and Wage Leadership", The Manchester School, 45, 258-69.

Cramton, P. C. and Tracy, J. S., 1994, "The Determinants of U.S. Labor Disputes", Journal of Labor Economics, 12, 180-209.

Crouch, C., 1977, The Politics of Industrial Relations, London:Penguin.

Dell'Aringa, C., 1988, Raporto sui Salari 1988, ASAP Unita Studi, Milan:Franco Angeli.

Dell'Aringa, C., 1992,"Industrial Relations and the Role of the State in the EEC Countries", in Pay and Employment in the New Europe, ed. D.Marsden, Aldershot: Edward Elgar.

Dereli, T., 1992, “Turkey”, European Labor Unions, ed. J.Campbell, Westport: Greenwood Press.

Dickens, W.T., 1986, "Wages, Employment, and the Threat of Collective Action by Workers", National Bureau of Economic Research Working Paper Series, No.1856.

Dickens, W.T. and Katz, L., 1987, "Inter-Industry Wage Differences and Industry Characteristics", in Unemployment and Structure of Labor Markets, eds. K.Lang and J.S. Leonard, New York: Basil Blackwell. 
Dickerson, A. P., 1994, "The Cyclicality of British Strike Frequency", Oxford Bulletin of Economics and Statistics, 56, 285-303.

Dicks-Mireaux, L.A., 1958, "Wage-Earnings and Wage-Rates, 1954-57", London and Cambridge Economic Bulletin, 14, 189-98.

Driehuis, W., 1975, "Inflation, Wage Bargaining, Wage Policy and Production Structure: Theory and Empirical Results for the Netherlands", De Economist, $123,638-79$.

Due, J., Madsen, J. S., Jensen, C. S., and Petersen, L. K., 1994, The Survival of the Danish Model, Copenhagen: DJOF.

Dunlop, J.P., 1957, "The Task of Contemporary Wage Theory", in New Concepts in Wage Determination, eds. G.W. Taylor and F.C. Pierson, pp.117-39, New York: MacGraw-Hill Book Company.

Eatwell, J., Llewellyn, J., and Tarling, R., 1974, 'Money Wage Inflation in Industrial Countries", Review of Economic Studies, 41, 515-23.

Ebbinghaus, B.O. and Visser, J., 1993, Trade Union Systems in Western Europe: Data Handbook vol.l, Frankfurt:Campus Verlag.

Eckstein, O. and Wilson, T.A., 1962, "The Determination of Money Wages in American Industry", Quarterly Journal of Economics, 76, 379-414.

Eckstein, O., 1968, "Money Wage Determination Revisitited", Review of Economic Studies, 35, 133-43.

Edgren, G., Faxén, K., and Odhner, C., 1973, Wage Formation and the Economy, London: Allen and Unwin.

Edgren, G., Faxén, K., and Odhner, C., 1969, "Wages, Growth and the Distribution of Income, Swedish Journal of Economics, 71, 133-60.

Elliot, R. F., 1991, Labor Economics: A Comparative Text, London: McGraw-Hill. Elster, J., 1989, The Cement of Society, Cambridge: Cambridge University Press. Erdil E., 1996a, "Inter-Industry Wage Differentials: An Analysis on Wages in Turkish Manufacturing Industry, 1980-1985", METU Studies in Development, 23, 119.

Erdil E., 1996b, "A Test for Wage Leadership Hypothesis in Turkish Manufacturing Industry", Economic Research Center (ERC) Working Paper, no.9, Middle East Technical University, Ankara.

Erdil E., 1997, “A Test for Wage Leadership Hypothesis", Applied Economics Letters, 4, 219-23. 
Ermisch,J., 1995, “Demographic Developments and European Labor Markets”, Scottish Journal of Political Economy, 42, 331 -46.

EUROSTAT, 1983-96, Labor Force Survey Results, Brussels: Office for Official Publications of the European Communities.

EUROSTAT, 1997a, EUROSTAT Yearbook'97, Luxembourg: Office for Official Publications of the European Communities.

EUROSTAT, 1997b, Employment in Europe, Luxembourg: Office for Official

Publications of the European Communities.

Flanagan, R.J., 1976, "Wage Interdependence in Unionized Labor Markets", Brookings Papers on Economic Activity, 7, 635-

Freeman, R.B. and Medoff, J.L., 1981, "The Impact of Percentage Organized on Union and Non-union Wages", The Review of Economics and Statistics,63, $561-72$.

Freeman, R.B., 1980, "Unionism and the Dispersion of Wages", Industrial and Labor Relations Review, 34, 3-23.

Geweke, J, Meese,R., and Dent, W., 1983, "Comparing Alternative Tests of Causality in Temporal Systems", Journal of Econometrics, 21, 161-94.

Geweke, J., 1978, “Testing the Exogeneity Specification in the Complete Dynamic Simultaneous Equation Model", Journal of Econometrics, 7, 163-85.

Graafland, J.J. and Verbruggen, J.P., 1993, "Macro Against Sectoral Wage Equations in the Netherlands", Applied Economics, 25, 1373-83.

Granger, C.W.J., 1969, "Investigating Causal Relations by Econometric Models and Cross Spectral Methods", Econometrica, 37, 428-38.

Griffiths, R.T., ed. The Economy and Politics of the Netherlands Since 1945, The Hague:Nijhoff.

Groenewegen, J., 1998, "Institutional Change in the Netherlands; Capital Markets and Labor Markets in Transition", Papers and Proceedings of EAEPE (European Association of Evolutionary Political Economy) Conference.

Groot, W. and Berg, A. van den, 1994, "Why Union Density has Declined", European Journal of Political Economy, 10, 749-63.

Harrison, A. and Stewart, M., 1994, "Is Strike Behavior Cyclical?", Journal of Labor Economics, 12, 524-53. 
Hartog, J., Oosterbek, H, and, Teulings, C., 1993, "Age, Wages and Education in the

Netherlands", in Labor Markets in an Ageing Europe, eds. P.Johnson and K.F.Zimmerman, Cambridge: Cambridge University Press.

Herman, E.E., 1998, Collective Bargaining and Labor Relations, New Jersey: Prentice-Hall.

Hicks, J. R., 1966, The Theory of Wages, New York: St. Martin's Press.

Hines, A.G., 1969, "Wage Inflation in the United Kingdom, 1948-1962: A

Disaggregated Study", Economic Journal, 79, 66-89.

Hodson, R. and England, P., 1986, "Industrial Structure and Sex Differences in Eamings", Industrial Relations, 25, 16-32.

Hoel, M. and Nymoen, R., 1988, "Wage Formation in Norwegian Manufacturing", European Economic Review, 32977-99.

Holden, S., 1987, Wage Drift in Norway: A Bargaining Approach, Memorandum, No:20, University of Oslo, Department of Economics.

Holden, S., 1988, "Local and Central Wage Bargaining", Scandinavian Journal of Economics, 90, 93-99.

Holden, S., 1989, "Wage Drift and Bargaining: Evidence from Norway", Economica, $56,419-32$.

Holden, S., 1998, "Wage Drift and the Relevance of Centralised Wage Setting", Scandinavian Journal of Economics, 100, $711-31$.

Holden, S. and Birkeland, T., 1995, Wage Drift and the Irrelevance of Centralized Wage Setting, Memorandum, No:1, University of Oslo, Department of Economics.

Holmlund, B. And Ohlsson, H., 1992, "Wage Linkages Between Private and Public Sectors in Sweden", Labour, 6, 3-17.

Hutchens, R., Lipsky, D., and Stern R., 1992, "Unemployment Insurance and Strikes", Journal of Labor Research, 13, 337-54.

ILO, 1968-1995, Yearbooks of Labor Statistics, Geneva:ILO.

ILO, 1995, Sources and Methods, Employment, Wages, Hours of Work, and Labor Cost (Establishments Survey), Volume 2, Geneva:ILO.

Işıkh, A., 1990, Sendikacılık ve Siyaset, Ankara:İmge Kitabevi.

Iversen, T., 1996, "Power, Flexibility and the Breakdown of Centralized Wage Bargaining: The Cases of Denmark and Sweden in Comparative Perspective", Comparative Politics, 28, 399-436. 
Jacoby, S.M., 1990, "The New Institutionalism: What Can It Learned from the Old?", in The Economy of Human Resource Management, eds. D.J.B. Mitchell and M.A. Zaidi, Oxford: Basil Blackwell.

Jensen, C.S., Due, J., and Madsen, J. S., 1994, "The Scandinavian Model in Europe: Choice of IR Roles for the Labor Market Parties at National and EU Levels", in Transformation of European Industrial Relations: Consequences of Integration and Disintegration, Helsinki: IIRA $4^{\text {th }}$ European Regional Congress, Vol. I, 45-67.

Johansen, L., 1979, "The Bargaining Society and the Inefficiency of Bargaining", Kyklos, 32, 497-522.

Johnson, G., 1977, "The Determination of Wages in the Union and Non-union Sectors ". British Journal of Industrial Relations, 15, 211-25.

Kahn, L.M., 1980, "Union Spillover Effects on Organized Labor Markets", The Journal of Human Resources, 15, 87-98.

Kahn, L., 1995, "Against the Wind: Bargaining Decentralization and Wage Inequality in Norway 1982-89", Unpublished manuscript, Cornell University.

Kahneman, D., Knetsch, J, and Thaler, R., 1985, "Perceptions of Unfairness Constraints in Wealth Seeking", mimeo, University of British Columbia.

Katzenstein, P.J., 1985, Small States in World Markets, Industrial Policy in Europe, Cornell University Press:Ithaca.

Kennan, J, 1986, "Strikes and Bargaining, in Handbook of Labor Economics, eds. O. Ashenfelter and R. Layard, Amsterdam: North-Holland.

Kerr, C., 1988, "The Neoclassical Revisionists in Labor Economics (1940-1960)", in How Labor Markets Work, ed. B.E. Kaufman, Maasachussetts:Lexington.

Ketenci, S., 1987, "İşçiler ve Çalışma Yaşamı: 1980'lerde Sınırlar ve Sorunlar", in Bırakınız Yapsınlar Bırakını Geçsinler, Türkiye Ekonomisi 1980-1985, ed. B.Kuruc, Ankara: Bilgi Yayınevi.

Kjellberg, A., 1992, "Sweden: Can the Model Survive?", in Industrial Relations in the New Europe, eds. A.Ferner and R.Hymann, Oxford: Blackwell.

Kleiman, E., 1971, “Wages and Plant Size: A Spillover Effect?”, Industrial and Labor Relations Review, 25, 243-48.

Knight, J.B. and Mabro, R., 1972, "On the Determination of General Wage Level: A Comment", Economic Journal, 82, 677-86. 
Koç, Y., 1996, Türkiye İş̧i Smıfı ve Sendikacıllk Tarihi: Olaylar-Değerlendirmeler, Ankara: Türkiye Yol-İs Sendikası Yayınları.

Koning, J.de, Nes, P.J. van, and Gesthuizen, C.C.P., 1996, Labor Market Studies:

Netherlands, Luxembourg: Office for Official Publications of the European Communities.

Koning, J.D., Heel, P.A.D. van, Gelderblom A., Nes, P.J. van, and Zandvliet, C.T., 1995, The Employment Service in Perspective : Evaluation of the Employment Act 1991-1994, Part B: Results and Costs, The Hague: Ministry of Social Affairs and Employment.

Kuhn, A., 1974, The Logic of Social Systems: A Unifled, Deductive System-Based Approach to Social Sciences, San Francisco: Jossey-Bass.

Kumar, P., 1972, "Differentials in Wage Rates of Unskilled Labor in Canadian Manufacturing Industries", Industrial and Labor Relations Review, 26, $631-45$.

Lange, P., Wallerstein, M., and Golden, M., 1995, "The End of Corporatism? Wage Setting in the Nordic and Germanic Countries", in Workers of Nations: Industrial Relations in A Global Economy, ed. S. Jacoby, Oxford: Oxford University Press.

Latsis, S., 1976, Method and Appraisal in Economics, Cambridge:Cambridge University Press.

Layard, R., Nickell, S., and Jackman, R., 1991, Unemployment: Macroeconomic Performance and the Labor Market, New York: Oxford University Press. Lehner, R., 1988, "The Political Economy of Distributive Conflict", in Managing Mixed Economies, eds. F.Castles, F.Lehner, and M.Schmidt, New York: Walter de Gruyter.

Lemer, S.W. and Marquand, J., 1962, "Workshop Bargaining, Wage Drift and Productivity in British Engineering Industry", Manchester School, 30, 311-22.

Lever, M.H.C. and Marquering, W.A., 1995, "Union Coverage and Sectoral Wages:

Evidence from the Netherlands", EIM Small Business Research and Consultancy, Department of Fundemental Research, Research Report, No.9507/E.

Lindbeck, A, 1990, The Swedish Experience, Seminar Paper of Institute for International Economic Studies, No: 482, Stockholm. 
Lindbeck, A., 1993, "Comment on Moene, Wallerstein and Hoel" in Trade Union Behavior, Pay Bargaining and Economic Performance, eds. R. Flanagan, K. O. Moene, and M. Wallerstein, Oxford: Oxford University Press.

Lindbeck, A., 1997, "The Swedish Experiment", Journal of Economic Literature, 35, 1273-1320.

Lindbeck, A., \& Snower, D. J., 1995, "The-Restructuring of Firms and the Segmentation of Labor Markets", Paper Presented at The Conference in Honor of Assar Lindbeck on Unemployment and Wage Dispersion--Is There A Trade-Off?, Stockholm: Sweden.

Maher, J.E., 1961, "The Wage Pattern in the United States, 1946-1957", Industrial and Labor Relations Review, 15, 3-20.

Marquand, J., 1960, "Earnings Drift in the United Kingdom, 1948-57", Oxford Economic Papers, 12, 356-65.

Martin, A., 1995, "The Swedish Model: Demise or Reconfiguration?", in, Employment Relations in A Changing World Economy, eds. T. Kochan, R. Locke, and M. Piore, Cambridge, MA: MIT Press

McCarthy, W.E.J., O'Brien, J.F., and Dowd, W.G., 1975, Wage Inflation and Wage Leadership, Dublin: The Economic and Social Research Institute.

McConnell, 1989, "Strikes, Wages, and Private Information", American Economic Review, 79, 801-15.

McDaid, M. A., 1995, "Workers' Rights and European Integration: An External View from the Nordic Area", in Work and Employment in Europe: A new Convergence?, eds. P. Cressey and $\mathrm{B}$. Jones, London: Routledge.

McGuire, T.W. and Rapping L.A., 1966, "Interindustry Wage Change Dispersion and the 'Spillover' Hypothesis", American Economic Review, 56, 493-501.

McGuire, T.W. and Rapping L.A., 1968, "The Role of Market Variables and Key Bargains in the Manufacturing Wage Determination Process", Journal of Political Economy, 76, 1015-36.

McGuire, T.W. and Rapping L.A., 1970, "The Supply of Labor and Manufacturing Wage Determination in the United States: An Empirical Examination", International Economic Review, 11, 258-68.

Mehra, Y.P., 1976, "Spillovers in Wage Determination in U.S. Manufacturing Industries", The Review of Economics and Statistics, 58, 300-312. 
Miltenburg, A.J.M.van, 1991, Labor Market Policy in a Social Market System:

Lessons from the Dutch Experience, Ministerie van Sociale Zaken en Werkgelegenheid.

Mitchell, D.J.B., 1978, "Union wage Determination: Policy Implications and Outlook", Brookings Papers on Economic Activity, 9, 537-82.

Mitchell, D.J.B., 1980, “Union/Non-Union. Wage Spillovers: A Note”, British Journal of Industrial Relations, 18, 372-76.

Mizala, A. and Romaguera, P., 1995, "Testing for Wage Leadership in the Chilean Economy", Applied Economics, 27, 303-310.

MLSS, 1970-1984, Calışma Dergisi, Ankara:MLSS.

MLSS, 1984-1997, Labour Statistics, Ankara:MLSS.

Moene, K. O., 1988, "Union's Threats and Wage Determination", Economic Journal, 98, 471-83.

Moene, K. O., and Wallerstein, M., 1993, "What's Wrong with Social Democracy?", in Market Socialism: The Current Debate, eds. P. Bardhan and J. Roemer, Oxford: Oxford University Press.

Moene, K. O., Wallerstein, M., and Hoel, M., 1993, "Bargaining Structure and Economic Performance", in Trade Union Behavior, Pay Bargaining and Economic Performance, eds. R. Flanagan, K. O. Moene, and M. Wallerstein, Oxford: Oxford University Press.

Moene, K. O. and Wallerstein, M., 1995a, "Solidaristic Wage Bargaining", The Nordic Journal of Political Economy, 22, 79-94.

Moene, K. O. and Wallerstein, M., 1995b, "How Social Democracy Worked: Labor Market Institutions, Politics and Society, 23, 185-211.

Moore, W.J., Newman, R.J., and Cunningham, J., 1985, "The Effect of the Extent of Unionism on Union and Non-union Wages", Journal of Labor Research, 6, 21-44.

Mulvey, C. and Trevithick, J.A., 1974, "Some Evidence on the Wage Leadership Hypothesis", Scottish Journal of Political Economy, 21, 1-11.

Neubourg, C. de, 1990, Unemployment and Labor Market - Flexibility: The Netherlands, Geneva:ILO.

Neumark, D. and Wachter, M.L., 1992, "Union Threat Effects and Non-union Industry Wage Differentials", National Bureau of Economic Research Working Paper Series, No.4046. 
Neumark, D. and Wachter, M.L., 1995, "Union Effects on Non-union Wages:

Evidence from Panel Data on Industries and Cities", Inclustrial and Labor Relations Review, 49, 20-38.

Nickell, S. J. and Andrews, M., 1983, "Unions, Real Wages and Employment in Britain 1951-79", Oxford Economic Papers, 35, Supplement, 183-206.

Nickell, S. J., and Wadhwani, S., 1990, "Insider Forces and Wage Determination", The Economic Journal, 100, 496-509

Nickell, S. J., Vainiomaki, J., and Wadhwani, S., 1992, "Wages, Unions, Insiders and Product Market Power", Centre for Economic Performance, LSE, Discussion Paper 77.

Nickell, S. J., Vainiomaki, J., and Wadhwani, S., 1994, "Wages, and Product Market Power", Economica, 61, 457-73.

Nordhaus, W.D., "The Worlwide Wage Explosion", Brookings Papers on Economic Activity, 3, 431-63.

OECD, 1970, Employment Outlook, Paris:OECD.

OECD, 1987, Employment Outlook, Paris:OECD.

OECD, 1988, Measures to Assist the Long-Term Unemployed: Recent Experiment in Some OECD Coumtries, Paris:OECD.

OECD, 1990a, Labor Market Poicies in 1990s, Paris:OECD.

OECD, 1990b, Employment Outlook, Paris:OECD.

OECD, 1991, Employment Outlook, Paris:OECD.

OECD, 1992, Employment Outlook, Paris:OECD.

OECD, 1993, Employment Outlook, Paris:OECD.

OECD, 1994a, The Labor Market in the Netherlands, Paris:OECD.

OECD, 1994b, The OECD Jobs Study, OECD:Paris.

OECD, 1995a, Labor Force Statistics, 1970-1993, Paris:OECD.

OECD, 1995b, The OECD STAN Database for Industrial Analysis, 1974-1993, Paris:OECD.

OECD, 1996, Employment Outlook, Paris:OECD.

Olsson, A. S., 1991, The Swedish Wage Negotiation System, Aldershot: Dartmouth. Oswald, A.J., 1981, "Threat and Morale Effects in the Theory of Wages", European Economic Review, 16, 269-83.

Oswald, A.J., 1985, "The Economic Theory of Trade Unions: An Introductory Survey", The Scandinavian Journal of Economics, 87, 160-93. 
Ours, J.C. van, 1991, "The efficiency of the Dutch Labor Market in Matching Unemployment and Vacancies", De Economist, 139, 358-78.

Pascoe, 1996, "Flexiwork: The Debate", The Netherlander, February 3 1996, 8-9.

Pencavel, J. H., 1985, "Wages and Employment Under Trade Unionism:

Microeconomic Models and Macroeconomic Applications", The Scandinavian Journal of Economics, 87, 197-225.

Plowman, D., Siebert, C.D., and Zaidi, M.A., 1986, "Market and Spillover Forces in Wage Award Determination in Australia", Applied Economics, 18, 191-203.

Podgursky, M., 1986,"Unions, Establishment Size, and Intra-Industry Threat Effects", Industrial and Labor Relations Review, 39, 277-84.

Pontusson, J., and Swenson, P., 1996, "Labor Markets, Production Strategies, and Wage Bargaining Institutions: The Swedish Employer Offensive in Comparative Perspective", Comparative Political Studies, 29, 223-50.

Pugel, T., 1980, "Profitability, Concentration, and Interindustry Variation in Wages", Review of Economics and Statistics, 62, 248-53.

Reder, M. and Neumann, G. R., 1980, "Conflict and Contract: The Case of Strikes", Journal of Political Economy, 88, 867-86

Reder, M., and Ulman, L., 1993, "Unionism and Unification", in Labor and An Integrated Europe, eds. L. Ulman, B. Eichengreen, and W. T. Dickens, Washington DC: Brookings Institution.

Rees, A., 1951, “A Postwar Wage Determination in the Basic Steel Industry”, American Economic Review, 41, 389-404.

Reuber, G.L., 1970, "Wage Adjustments in Canadian Industry, 1953-1966", Review of Economic Studies, 37, 449-68.

Rima, I.H., 1981, Labor Markets, Wages, and Employment, New York:W.W. Norton \& Company.

Roo, A.de and Jagtenberg, R., 1994, Settling Labor Disputes in Europe, Boston: Kluwer Publishers.

Rood, M.G., 1995, “The Netherlands”, in International Encylopedia for Labor Law and Industrial Relations, ed. R. Blanpain, The Hague: Kluwer Law International.

Rosen, S., 1969, "Trade Union Power, Threat Effects, and the Extent of Organization", Review of Economic Studies, 36, 185-96. 
Ross, A.M., 1948, Trade Union Wage Policy, Berkeley: University of California Press.

Runciman, W.G., 1966, Relative Deprivation and Social Justice, London: Routledge and Keagan Paul.

Sargan, J.D., 1971, “A Study of Wages and Prices in the U.K. 1949-1968”, in The Current Inflation, eds. H.G. Johnson and A.R. Nobay, London: Macmillan Publishers, Ltd.

Sargent, T.J., 1976, "A Classical Macroeconometric Model of the U.S.", Journal of Political Economy, 87, 207-37.

Scheuer, S., 1992, "Denmark: Retum to Decentralization", in Industrial Relations in the New Europe, eds. A. Ferner and R. Hyman, Oxford: Blackwell.

Schiller, B., 1994, "The Future of the Nordic Model of Labor Relations", in The Future of the Model of Labor Relations: Three Reports on Internationalization and Industrial Relations, ed. B.Schiller, Nord, No:36.

Schmidt, J. and Strauss, R., 1976, "The Effect of Unions on Earnings and Earnings on Unions: A Mixed Logit Approach", International Economic Review, 17, 20412.

Schmitter, P., 1974, "Still the Century of Corporatism?", in The New Corporatism, eds. F. Pike and T. Stritch, pp.85-131, Notre Dame: University of Notre Dame Press.

Schmitter, P., 1977, "Modes Interest Intermediation and Models of Societal Change in Western Europe", Comparative Political Studies, 10, 7-38.

Schmitter, P., 1981, "Interest Intermediation and Regime Governability in Contemporary Western Europe and North America", in Organizing Interests in Western Europe, ed. S.D. Berger, Cambridge: Cambridge University Press.

Schnell, F. and Gramm, L., 1994, "The Empirical Relations Between Employers' Striker Replacement Strategies and Stirke Duration", Industrial and Labor Relations Review, 47, 189-206.

Seltzer, G., 1951, "Pattern Bargaining and the United SteelWorkers”, Journal of Political Economy, 59, 319-31.

Sims, C.A., 1972, "Money, Income, and Causality". American Economic Review, 62, 540-52.

SIS, 1970-1995, Annual Manufacturing Industry Statistics, Ankara:SIS. SIS, 1988-1995, Household Labor Force Surveys (HLFS), Ankara:SIS. 
SIS, 1994, Statistical Indicators, 1923-1994, Ankara:SIS.

SIS, 1995, Labor Statistics, Ankara:SIS.

SIS, 1996, Labor Statistics, Ankara:SIS.

Slichter, S.H., 1954, "Do the Wage-Fixing Arrangements in the American Labor Market Have an Inflationary Bias?", Proceedings of American Economic Association, 4, 322-46.

Snodgrass, D.R., 1963, "Wage Changes in 24 Manufacturing Industries 1948-1959: A Comparative Analysis", Yale Economic Essays, 3, 177-221.

Sparks, G.R. and Wilton, D.A., 1971, "Determinants of Negotiated Wage Increases: An Empirical Analysis", Econometrica, 39, 739-50.

Streeck, W., 1993, "The Rise and Decline of Neocorporatism", in Labor and An Integrated Europe, eds. L. Ulman, B. Eichengreen, and W. T. Dickens, Washington DC: Brookings Institution.

SZW (Ministry of Social Affairs and Employment), 1990, Social Security in the Netherlands, Deventer: Kluwer Law and Taxation Publishers.

SZW (Ministry of Social Affairs and Employment), 1996, EMU:Employment Effects and Policy Tools, SZW:Den Haag.

Şenses, F., 1990, "Türkiye'de Gelir Dağılımı, Gelirin Yeniden Dağıtımı, ve İşgücü Piyasaları", Economic Research Center, Working Paper, No.3.

Şenses, F., 1994, “Labor Market Response to Structural Adjustment and Institutional Pressures: The Turkish Case", METU Studies in Development, 21, 405-48.

Tarantelli, E. ,1986, Economia Politica del Lavoro, Torino:Utet.

Teulings, J. and Hartog, J., 1998, Corporatism amd Competition: Labor Contracts, Institutions and Wage Structures in International Comparison, Cambridge: Cambridge University Press.

The Netherlander, 1996, "Temp Agencies See Potential", 9.

Thurow, L., 1978, “Psychic Income: Useful or Useless?”, American Economic Review, 68, 142-45.

Tobin, J., 1972, "Inflation and Unemployment", American Economic Review, 62, $1-18$.

Turner, H.A. and Jackson, D.A.S., 1969, "On the Stability of Wage Differences and Productivity-Based Wage Policies: An International Analysis, British Journal of Industrial Relations, 7, 3-18. 
Turner, H.A. and Jackson, D.A.S., 1970, "On the Detremination of General Wage

Level: A World Analysis- or Unlimited Labor Forever", Economic Journal, $80,827-49$.

UFT, 1994, Imalat Sanayi Sektörel Ihracat ve Ithalat Verileri, unpublished, Ankara:UFT.

Unterberger, S. and Koziara, C., 1980, "The Demise of Airline Strike Insurance", Industrial and Labor Relations Review, 34, 82-89.

Veen, T.van, 1997, Studies in Wage Bargalning, The Influence of Taxes and Social Security Contributions on Wages, Maastricht: Maastricht University Press.

Ven, J.J.M. van der 1986, Contribution to Fifty Years of Labor Law and Social Security, Deventer: Kluwer Law International.

Visser, J., 1989a, European Trade Unions in Figures, Deventer: Kluwer Publishers.

Visser, J., 1989b, "New Working Time Arrangements in the Netherlands, in Current Issues in Labor Relations-An International Perspective, ed. A. Gladstone, Berlin:de Gruyter.

Visser, J., 1990, "Continuity and Change in Dutch Industrial Relations", European Industrial relations: The Change of Flexibility, eds. G.Bagliani and C.Crouch, London: Sage Publications.

Visser, J., 1992, "The Netherlands: The End of an Era and the End of a System", Industrial Relations in the New Europe, eds. A.Ferner and R.Hyman, Oxford:Basil Blackwell.

Visser J. and Hemerijck, A., 1997, A Dutch Miracle, Job Growth, Welfare Reform and Corporatism in the Netherlands, Amsterdam:Amsterdam University Press.

Voorden, W. Van, 1984, "Employers Associations in the Netherlands", Employers Associations and Industrial Relations, eds. J.P. Windmuller and A. Gladstone, New York: Clarendon Press.

Voorden, W. Van, 1992, "The Netherlands", European Labor Unions, ed. J. Campbell, Westport: Greenwood Press.

Voskamp, A., 1994, Collective Labor Negotiations and Arbitration for the Netherlands, Working Paper, University of Amsterdam, Department of Economics.

Vroman, S., 1982, "The Direction of Wage Spillovers in Manufacturing", Industrial and Labor Relations Review, 36, 102-112. 
Vroman, S., 1989, "A Longitudinal Analysis of Strike Activity in U.S.

Manufacturing: 1957-1984", American Economic Review, 79, 816-26.

Vroman, W., 1982, "Union Contracts and Money Wage Changes in U.S.

Manufacturing Industries", Quarterly Journal of Economics, 96, 571-94.

Vroman, W., 1984, "Wage Contract Settlements in U.S. Manufacturing”, The Review of Economics and Statistics, 66, 661-65.

Wallerstein, M. and Golden, M., 1997a, "The Fragmentation of the Bargaining Society: Wage Setting in the Nordic Countries, 1950-1992, Comparative Political Studies, 30, 699-732.

Wallerstein, M., Golden, M., 1997b, "Unions, Employers Associations and WageSetting Institutions in North and Central Europe, 1950-1992", Industrial Labor and Relations Review, 50, 379-401.

Walton, R. E. and McKersie, R. B., 1991, A Behavioral Theory of Labor Negotiations, New York: ILR Press.

Williamson, O. E., Wachter, M. L., and Harris, J. E., 1975, "Understanding the Employment Relation: The Analysis of Idiosyncratic Exchange", The Bell Journal of Economics, 6, 250-80.

Windmuller,J.P., 1969, Labor Relations in the Netherlands, New York:Cornell University Press.

Wolff, P.de, 1983, "Income Policy Developments in the Netherlands", Industrial Relations, 22, 203-23.

World Bank, 1982, World Development Report, New York: The World Bank Publications.

Wulfsberg, F., 1997, "An Application of Wage Bargaining Models to Norwegian Panel Data", Oxford Economic Papers, 49, 419-41. 


\section{SAMENVATTING}

Deze studie gaat over de theoretische en imperische analyse van het loonsprocess. Als erste worden twee concurrerende theorieen, namelijkde neo klassieke en de institutionele theorieen van de arbeidsmarkt op terugblikkende wijze bestudeerd. De imperische literatuur die in het teede hoofdstuk herzien geworden is, biedt gegrond bewijs voor de toopasselijkheid van institutionele theorieen in de arbeidsmarkt. Dit wil niet zeggen dat de neoklassieke theorie geheed verworpen wordt, narr dat deze twee theorieen elkaar eigenlijk aanvullen. Omdat de institutionele theorie gebruik maakt van de grond regels van de neoklassieke theorie, is het onmogelijk te beweren dat de neoklassieke theorie totaal niet van toepassing is. Het gebruik van neoklassieke postulaten kan gezien worden als de zwakste zijde van de institutionele theorie.

In het derde hoofdstukvan dit proefschrift worden de verschillende modellen afgeleid; één is een neoklassiek model en de andere is een voorbeeld van een institutionele theorie. Als wordt voorgesteld in deconclusie van het tweede hoofdstuk een van de meest consequente theorien van "spillover" in de arbeidsmarkt is die van de loon leiderschaps theorie. Alhoewel deze theorie gebruik maakt van rationele keuze theorie postulaten die vrij neoklassiek van aard zijn, maakt het loon leiderschap model in dit proefschrift gebruik van een loon bepalings process dat de institutionele effecten en institutionele omgeving niet negeert.

Het daarop volgende hoofdstuk concentreert zich op een uitvoerigeanalyse van eigenschappen van de Turkse en Nederlandse arbeidsmarkt. De hoofd punten van deze analyse zijn de geschiedenis van het arbeidsmarkt beleid, de hoofdeigenschappen van arbeidsmarkten in het algemeen- arbeidskrachten en werkeloosheids structuur inbegrepen- werkgelegenheid en lonen in de fabricage industrie sector, instelligen in de arbeidsmarkt, en het wettelijke kader van industriele verbanden.

De geschiedenis van de na-oorlogse arbeidsmarkt in Nederland toont een tendens naar decentralisatie. De problemen veroorzaakt door de oorlog maakten de invoering van zeer gecentraliseerde beleiden noodzakelijk. De gestuurde loon en arbeidsbeleiden werden in de tweede helft van de zestiger jaren beeindigd. Een andere onderscheidende eigenschap van deze kwestie is de grote hoeveelheid aan eenstemmigheid onder werknemers, werkgevers en de regering. Tegenwoordig is het beleid gericht op reorganisatie van het verband tussen werk en werkgelegenheid. Het 
nieuwe beleid streeft naar buigzaamheid in de arbeidsmarkt om de nieuwe amstandigheden tegemoet te komen en arbeidsloosheid te verminderen.

Wat betreft deelname zien we een geleidelijke stijging in deelname cijfers, voornamelijk vanaf de tweede helft van de tachtiger jaren stijgt dit cijfer vrij snel. De voornaamste redenen voor de niet-deelname gezien in 1990 en 1996 zijn personlijke en gezins verantwoordelijkheden, pensioen, onderwijs, en arbeids ongeschiktheid. Als gevolg van dit op buigzaamheid en stijgend werkelosheid gerichtte beleid wordt het deel van part-time werkgelegenheid steeds groter. De toename van werkeloosheid tot midden 1980 is de meest zichtbare eigenschap van de arbeidsmarkt in Nederland. Deze toename kan toegeschreven worden aan de toename van werkkracht en beperkend macroeconomisch beleid. Bovendien is bijna de helft van arbeidslozen arbeidsloos voor een langere tijd. Maar de toenemende trend in arbeidsloosheids cijfers is omgekeerd door het toepassen van een successvol beleid in de laatse 10 jaar.

Het arbeids gelegenheid deel van de vervaardigende industrie volgt een on onderbroken terugname in de jaren 80 en 90 , net als in het geval van andere geindustrialiseerde OECD landen. Niet allen het arbeidsdeel in de vervaardigende industrie, maar ook de totale werkgelegenheid in de vervaardigende industrie loopt terug. Confectie en schoenen industrie worden gezien als laag-loon industrieen, maar olie en kool produktie en rafinaderijen zijn hoog-loon industrieen. Tussen de jaren 1970 en 1993 liggen de lonen in de Nederlandse industrie verder uitelkaar. In deze zelfde periode volgen de reele uurlonen een toenemende trend en stijgen $160 \%$.

Wat betreft de instelligen in de Nederlandse arbeidsmarkt loopt het deel van georganiseerde arbeid terug, en ongeveer $70 \%$ van alle werknemers is ongeorganiseerd en dit verzwakt de Nederlandse arbeids beweging. In tegenstelling tot werknemers zijn de werkgevers minder georganiseerd en minder geneigd kollektief op te treden; op het centrale niveau zijn er naast elkaar bestaande organisaties die de werkgevers verenigingen en zelfstandige firmas vertegenwoordigen. Wettelijk gezien is in de loop van tijd het effect van het centrale beleid en ander centraal georganiseerde instellingen op het loon bepalings process verminderd en is de wettelijke benadering meer individueel geworden. Maar vanaf midden 1990 is er een trend van toenemende centrale invloed onstaan.

De belangrijkste politieke en economische veranderingen vormden het arbeidsmarkt beleid in Turkije. Tijdens de overgang van het meerdere prtijen systeem naar geplamde economie en van geplande economie naar de liberale phase zijn er 
verschillende en min of meer tegenstrijdige strategieen toegepast door de regeringen. Eigenlijk is het moelijk te zeggen dat er in tijden van politieke chaos politieke voorschriften en geplande doelen toegepast zijn of dat er een realistisch arbeids beleid gevoerd is. Wat voornamelijk werkgelegenheid wormt in steden is de ononderbroken migratie van het land naar stads gebieden. De migratie van ondergeschikte en laag geschoolde dorpelingen naar de stad veroorzaakte structurele problemen voor de arbeidsmarkt. In de $80 \mathrm{er}$ jaren is de grootste nadruk gelegd op het opnieuw richten van het beleid op zowel binnenlandse "factor" markten als het buitenlandse handels beleid. Deze verschillende gedragslijnen beinvloeden de arbeidsmarkt op indirecte wijze. Voor de tweede halft van de 80 er jaren beweert de regering dat door dirt soort beleidshervormingen het mogelijk woordt meer arbeids intensieve technologie te gebruiken en te specialiseren in werkzaamheden die overeenkomen met bestaande "factor" verdeling. Maar in het begin van de 90er jaren is de structuur van productie geleid in overeenstemming met het werkgelegenheids scheppings doel dat rekening houdt met zowel productiviteit en doeltreffendheid. Wat betreft het buitenlands handelsbeleid, het teweegberngen van een exporteerbaar overschot en het onder controle houden van de inflatie mak een binnenlandse vraag beperking voornamlijk gebaseerd op een loonsbeperking noodzakelijk. Loonsbeperking is ook belengrijk als een instrument voor het bereiken van internationale concurrentie met een export georienteerde strategie, en lonen werden ook gezien als een belangrijke kosten post. Maar het is niet mogelijk het standpunt dat deze beleids patronen succesvol zijn wat betreft het scheppen van arbeidsgelegenheid te verdedigen. Eigenlijk onderbruikte capaciteit geheractiveerd en nieuwe capaciteit wordt niet gecreerd. Het lijkt dat de invloeden op de aanbodzijde van de arbeidsmarkt door zullen gaan de arbeidsmarkt te vormen in de nabije toekomst. Het aantal nieuwe deelnemers in de arbeidsmarkt met hogere concentraties in stadsgebieden toont aan dat werkgelegenheids schepping te kort schiet aan de druk van de aanbodzijde.

De voornamste eigenschap van de Turkse arbeidsmarkt is de uit drie delen bestaande gesegmenteerde structuur. Deze drie bindende structuur bestaat uit de landbouw, stedelijk informele en de formele sector. Als we de deelname cijfers tussen 1970 en 1985 bekijken is de geobserveerde realiteit een regelmatige daling in deelname cijfers. Het deelname cijfer daalt van $64 \%$ naar $50 \%$. En ander belangrijk punt is dat het deelname cijfer van mannen aanzienlijk hoger dan dat van vrouw ligt. Dit betekent dat vrouwen in Turkije niet zo succesvol zijn in hun integratie in de 
arbeidsmarkt en dat ze kiezen als huisvrouw thuis te blijken. De hoofd reden voor mannen niet te werken is gepensioneerd of arbeidsongeschikt zijn. Maar aan het eind van de 70er jaren bereikt het arbeidsloosheids cijfer het hoogste punt. In de eerste helft van de jaren 90 lijkt het rond $8 \%$ stabiel te staan. Maar sommige onderzoekers houden vol dat de officiele statistieken onjuist zijn en dat het echte het arbeidsloosheids cijfer hoger ligt. Bovendien heeft werkeloosheid in Turkije een lange-duur eigenschap.

In de periode 1970-1994 stijgen zowel het werkdeel als het werkniveau in de fabricage industrie. Met aantal arbeiders in deze industrie stijgt meer dan $100 \%$ in deze periode. Wat betreft de loonstructuur in de fabricage industrie in Turkije bestaat de laag-loon industrie voomamelijk meubelmakerij en montage, confectie, en leervervaardiging en bewerking. Aan de andere kant bestaan de hoog-loon industrie takken voornamelijk uit de olie raffinaderij, productie van uit kool o olie bestaande producten en de chemische industrie. Loon uiteenloping is vrij hoog in de 70er jaren, maar daarna loopt het terıg in de jaren 80 en toont weer een stijgende ternd in de jaren 90. De reeele lonen in de fabricage industrie volgen geen stabiel pad. Er zijn grote stijgingen en dalingen in sub-perioden. In de laatste jaren is er sprake van een stijging in reëele lonen. Als dit vergeleken wordt met het niveau in 1970 is de stijging hoger dan $100 \%$.

De vakbonden beweging heeft tegenover grote wettelijk en politieke belemmeringen gestaan. Tot 1947 was het verboden om lid te worden van een vakbond en later werden vakbonden toegestaan, maar zonder stakingsrecht. Met de grondwet van 1961 werden vrijheid van vakbonden, gezamelijke loonsderhandeling en het recht te staken gegarendeerd. In 1980 werd de vakbonden beweging aangevollen door de militaire regeringen alle vakbond werkzaamheden opgeschort. De nieuwe grondwet van 1982 en nieuwe wetgeving zijn erg beperkend voor vakbond werkzaamheden. Vakbond dichtheid cijfers schommelen tussen 55 en $70 \%$ van 1984 tot 1997 , en in de eerste helft van 1997 is het $66 \%$.

In Turkije zijn werkgevers zich later gaan organiseren dan werknemers. Werkgevers bonden zijn begonnen meer influentie uit de werken na 1970. De belangrijkste aanwinsten van deze bonden zijn vekregen in de eerste helft van de $80 \mathrm{er}$ jaren en hebben een grote rol gespeeld in het wetgevings process en bijna alle vereisten werden gelegaliseerd. Tenslotte hebben zowel werknemers als werkgevers bonden een zeer gecentraliseerde structuur. 
In wettelijk kader zijn de werknemers rechten die geledelijk gewonnen werden an de stichting van de republiek tot 1980 geblokeerd door de grondwet van 1982 en de huidige wetgeving. Deze zijn zeer beperkend en beschermen de werkgever meer dan de werknemer.

In het vijfde hoofdstuk worden twee modellen voor loons inflatie vergeleken met de SUR methode voor de Nederlandse fabricage industrie. Het neoklassieke model wordt ongeschikt gezien om de loonsgroei te verklaren. Wonderlijk genoeg zijn de waarde oplegging en reëele loon variabellen niet van belang voor meeste sectoren. Alleen arbeidsmarkt dichtheid cijfers en "opportunity cost of labor" cijfers geven veelbetekenende resultaten. Drukkerij, uitgeverij en verenigde indutieen en industrie chemicalien vervaarddigings industrieen blijken de loon leidende sectoren te zijn van de Nederlandse industrie. Alle test resultaten tonen aan dat het loon leiderschap model de loongroei in de Nederlandse fabricage industrie voldoende verklaart en dat de belekenis van de variabelen die ook in het neoklassieke model bestaan, verbetert met de invoer van de loon leiderschap variabel. Daarom is er aanwijzing ten gunste van het bestaan van loon leidende en loon volgend gedraag in de Nederlandse fabricage industrie. We bepalen twee kandidaten als bron van loon leidenden loon volgend gedrag, namelijk concentratie en vereniging. In twee aparte systemenvan regressies tonen de coeficianten van vereniging en concentratie variabelen aan dat loons veraderingen doorgezond worden voor 17 sectoren van de Nederlandse fabricage industrie door een of andere van deze kanalen. Tests voor het type van leidend-volgend gedrag in de Nederlandse fabricage industrie laten blijken dat loon volgend gedrag is in de vorm van strenge imitatie inplaats van de zwakke. Ter conclusie verklaart ons model de yeronderstelling van de loon leiderschap hypothese voor de Nederlandse industrie voor geldig.

De zelfde stappen zijn in hoofdstuk 8 voor de Turkse fabricage industrie. Het neoklassieke model is enigszins beter in het uitleggen van de loongroei in de Turkse fabricage industrie vergeleken met de Nederlandse. Het enige interessant resultaat zijn de onbetekerende coefficienten op de produktiviteit variabel. Voedsel vervaardigeng en olie rafinaderijen blijken de loon bepalende sektoren te zijn. Het loon leiderschap model werkt voor aantonen van het loon bepalings process in de Turkse fabricage industrie omdat in 28 sectoren de loon leidings coefficeienten veelbetekenend zijn. Bovendien is het loon volgend gedrag in stricte vorm. Tenslotte allen maar in 2 industrieen is noch concentratie no vereniging het loon transmissie kanaal gebleken 
maar voor de overige 27 industrieen verklaren deze volvende hoe loonsverandering van de ene sector naar de andere door gezonden wordt. Ter hervatting, alhrewel het neoklassieke model de lonen groei tot een zeker extent gred verklaart is er vast bewijs voor het bestaan van loonleidend en volgerd gedrag in de Turkse fabricage industrie en het loonleidings model is erg sterk in het verkloren van loon groei in de fabricage industrie.

Hoofdstuk 9 is een discussie van de resultaten met betrekking tot het vormen van het beleid. Er zijn door traditie gevormde verschillen tussen de corporatiste ervaringen van Nederland en Turkije. Bovendien verschillen deze twee landen ook vat betreft het succes van deze corporatiste beleiden door de tijde heen. Corporatiste componenten in de arbeidsmarkt kunnen het succes in het Nederlandse loons matigings beleid, het buitengewoon aantal banen vrijgemaakt en de daardoor resulterende afname in werkloosheid verklaren. Dit success helpt ons ook de rustige industriele relaties te verklaren vergeleken met die in andere Europese landen. Maar deze stelling hondt niet in het geval van Turkije omdat de verschillende beleiden gevolgd door adtereen volgende regeningen niet voldonde geweert zijn om de hoofd dimensies van de arbeidsmarkt met haar belangrijkeoneven wichtigheden in aanwerking te nemen. Dezen achtereenvolgende beleiden kunnen worden als inconsequent, en habben soms onzekerheid en conflicten vervoorzaakt in industriele relaties.

Als een onderzoek in loons inflatie zijn er dit onderzoek testen voor zowel het neoklassieke als het de loon leiderschap modellen voor de Nederlandse en Turkse fabricage industrieen verricht Alhoewel we enig bewijs gevonden hebben voor de toepasselijkheid van het neoklasiieke model, is dit model in zichzelf niet voldoende in het verklaren van de dynamieken van loons veranderingen. Het loon leiderschap model werkt beter voor beide landen en institutionele kanalen van loons transmissie zijn het meest everkran gevonden in dit process. Maar de toepasselijk heid van deze model kan afhangen van subjectieve toestanden in deze landen of de beschouwde tijdsperiode, of de modellen kunnen verrijkt worden met de introductie van nieuwe variabelen. Maar we bereiken belangrijke en ontegenzeglijke conclusies in het belang van institutionelemechanismen in het bepalen van loonen in Nederland en Turkije. 


\section{Curriculum Vitae}

Erkan Erdil (Ankara,1968) studied Political Science and Public Administration at Middle East Technical University (METU) in Ankara. He received Bachelor of Science degree in 1990. In 1990, he started studying Economics at the same university. He received Master of Science degree in 1994.

He worked for The Undersecretariat of Treasury and Foreign Trade in Ankara between 1990 and 1991. He was appointed as research assistant at the Department of Economics, METU in 1992. He studied in various research projects for World Bank in 1994, FAO in 1996 and 1999, and ILO 1999. In 1995, he is selected for a scholarship for a research study in the Netherlands by NUFFIC and studied in University of Maastricht (previously University of Limburg). He was appointed as instructor and as the vice-chairman of the Department of Economics at METU (Middle East Technical University) in 1997. He taught introductory economics, statistics, econometrics, and technology and work organization courses. His main areas of interest are labor economics, applied econometrics, economics of information and uncertainty, and agricultural economics. He has been author/co-author of articles in Applied Economics, Applied Economics Letters, METU Studies in Development and ERC (Economic Research Center-METU) working paper series and presented papers to various international conferences. 